PHYSIOLOGICAL AND BEHAVIORAL DIAGNOSTICS OF NITROGEN LIMITATION FOR THE TOXIC DINOFLAGELLATE Alexandrium fundyense

By

Nicole Jane Poulton

B.S. Virginia Polytechnic Institute and State University, USA 1993

SUBMITTED IN PARTIAL FULFILLMENT OF THE REQUIREMENTS FOR THE DEGREE OF

DOCTOR OF PHILOSOPHY

at the

MASSACHUSETTS INSTITUTE OF TECHNOLOGY

and the

WOODS HOLE OCEANOGRAPHIC INSTITUTION

September 2000

(C) 2000 Nicole J. Poulton

A 11 -inhto macarrad
MBL/WHOI

Woods Hole, MA

Marine Biological Laboratory

Woods Hole Oceanographic Institution 
To Mum and Dad, for showing me the world and giving me the opportunity to fulfill my dreams. 


\section{TABLE OF CONTENTS}

Abstract

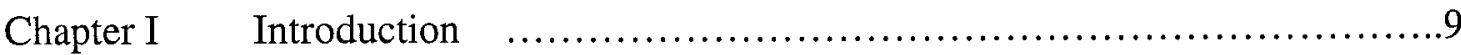

Chapter II Immuno-detection and separation of the toxic dinoflagellate Alexandrium fundyense from field samples using flow cytometry and magnetic beads

Chapter III Physiology and behavior of Alexandrium fundyense from Casco Bay, Maine during nitrogen limitation.

Chapter IV Toxin variability in natural populations of Alexandrium fundyense in Casco Bay, Maine - Evidence of nitrogen limitation.

Conclusions

Abbreviation and Acronyms 242

Acknowledgements .245 


\title{
Physiological and behavioral diagnostics of nitrogen limitation for the toxic dinoflagellate Alexandrium fundyense
}

by

\author{
Nicole Jane Poulton
}

\author{
Submitted in partial fulfillment of the requirements for the degree of \\ Doctor of Philosophy
}

\begin{abstract}
One challenge in phytoplankton ecology is to measure species-specific physiological responses to changes in environmental conditions. Of particular importance in this regard are harmful algal bloom (HAB) species such as the toxic dinoflagellate Alexandrium fundyense which typically inhabit coastal regions where they are not usually dominant. Within the Gulf of Maine, environmental factors, specifically nitrogen, are likely to be a controlling factor for A. fundyense blooms. Therefore, the ability to ascertain the nutritional status of this species in field assemblages in critical to understanding its bloom dynamics. The aim of this thesis was to identify physiological and behavioral indicators or diagnostics of $A$. fundyense from the Gulf of Maine, and to evaluate these on naturai populations in the Casco Bay region.

Using a species-specific monoclonal antibody, two methods for identifying and separating $A$. fundyense from natural field assemblages were developed. The first used a species-specific antibody and flow cytometry to successfully detect and separate $A$. fundyense from co-occurring organisms, including other dinoflagellates of equivalent size. In particular the fluorescence associated with the antibody labeling was not sufficient of itself for species discrimination - natural red chlorophyll autofluorescence was also needed as a second parameter for identifying and sorting $A$. fundyense. A second antibody method was then investigated using immunomagnetic beads to successfully separate live A. fundyense from spiked field samples. The separated cells were then used to obtain accurate chlorophyll, protein and biomass estimates. $\mathrm{CHN}$ values were only accurate if the unbound magnetic beads were sieved from the sample prior to analysis. This is probably needed for carbohydrate analysis as well.

Since $A$. fundyense usually inhabits coastal areas that are frequently limited by nitrogen, behavioral adaptations and intracellular responses to nitrogen availability are a primary consideration. It was therefore necessary to identify diagnostic indicators and behavioral adaptations of $A$. fundyense to nitrogen stress. Using laboratory water columns, nitrogen $(\mathrm{N})$-starved batch cultures, and $\mathrm{N}$-limited, semicontinuous cultures, indicators of different $\mathrm{N}$-nutritional states were identified. It was determined that low
\end{abstract}


$\mathrm{N}$ concentrations in the surface of a mesocosm did not induce a Casco Bay A. fundyense isolate to vertically migrate to deep nutrient pools. Prolonged $\mathrm{N}$-stress caused dramatic changes intracellular biochemistry, specifically chlorophyll a, carbohydrate, and protein content, as well as $\mathrm{C}: \mathrm{N}$, toxin content and composition. Ratios of different toxin derivatives were identified that increased with increasing $\mathrm{N}$-stress and appear to be sensitive and robust indicators of $\mathrm{N}$-status.

Once indicators were developed for $\mathrm{N}$-stress, variability in toxin content and composition were examined in the coastal waters of Casco Bay, Maine during an A. fundyense bloom in the spring of 1998. Over the course of the field season, toxin compositional changes did occur that were generally consistent with increasing levels of $\mathrm{N}$-stress as the bloom progressed and $\mathrm{N}$ levels decreased. As observed in $\mathrm{N}$ limited culture, large increases in some toxin ratios (e.g., GTX1,4:STX and NEO:STX) were observed during the latter portion of the field season, coinciding with low $\mathrm{N}: \mathrm{P}$ ratios and undetectable levels of dissolved inorganic nitrogen. Overall, the toxin compositional trends are quite remarkable and suggest that this approach may provide valuable species-specific physiological information without the need for elaborate cell separation schemes such as flow cytometry or immunomagnetic bead sorting. Further laboratory studies are needed to better characterize the toxin response of $\mathrm{A}$. fundyense isolates to environmental stresses before this suite of toxin indicators can be considered robust. 


\section{CHAPTER 1}

\section{GENERAL INTRODUCTION}


Over the past several decades, there has been a dramatic increase in the problems associated with harmful algal blooms (HABs), commonly called "red tides", throughout the world (Anderson 1995). Only in the last few years have the scientific and commercial communities recognized the impact toxic blooms have on all components of the marine food-web, affecting viability, growth, fecundity, and recruitment. Formerly only a few regions of the world were affected by $\mathrm{HABs}$, but within the last decade new regions have been threatened and in many cases over large geographic areas and by more than one harmful or toxic species (Anderson 1989; Hallegraeff 1993).

$\mathrm{HAB}$ events are commonly characterized by an increase or dominance of a particular toxic or harmful alga. In particular, the division Dinoflagellata contains some of the most widely distributed species of toxic microalgae. Some of the common characteristics of these toxic dinoflagellates are biflagellation, a neritic or estuarine distribution, and the production of potent toxic secondary metabolites (Taylor 1987). One of these groups of toxic compounds is saxitoxin (STX), and contains greater than 20 known derivatives (Oshima et al. 1993). In the U.S. this toxin group is responsible for the most widespread and serious national $\mathrm{HAB}$ problem, paralytic shellfish poisoning (PSP), a potentially fatal neurological disorder caused by the ingestion of shellfish that accumulate the algal toxins to levels that can be lethal to humans or other consumers (Shumway 1990). PSP toxins are also known to accumulate in the viscera of some fish (some commercially important) such as herring and sardines, also posing a threat to human health. In addition, larger marine organisms (e.g. whales, seabirds, and porpoises) can ingest these toxins via the food chain at potentially lethal levels (Geraci et al. 1989; Anderson 
and White 1992). PSP toxins also induce alterations of marine trophic balance through adverse effects on larvae and other life history stages of fisheries species (White et al. 1989; Montoya et al. 1996).

In the U.S., PSP outbreaks are frequently associated with blooms of the toxic dinoflagellates in the genus Alexandrium, in particular A. fundyense and A. tamarense (hereafter collectively termed A. fundyense). In the northeast region, specifically the Gulf of Maine, this phenomenon is relatively new and has expanded rapidly over the past two decades. It is now recurrent and widespread affecting thousands of miles of U.S. coastline (Anderson 1997). Alexandrium blooms do not persist throughout the year but are seasonal and recurrent in nature. They typically are short in duration and have relatively low cell densities such that $A$. fundyense is often outnumbered by co-occurring phytoplankton. One of the survival strategies that allows this species to persist through the winter is that it undergoes sexuality and forms of benthic cysts that lie dormant in the bottom sediments for most of the year. The regulatory mechanisms that trigger cyst production at the end of a bloom or that initiate germination at the beginning of the bloom are not well understood. Many issues concerning the sexual cycle of Alexandrium are still to be resolved. However, laboratory studies have shown that nitrogen-, phosphorus-, and iron-limitation cause induction of sexuality and cyst formation (Anderson et al. 1984; Anderson and Lindquist 1985; Doucette et al. 1989). These transitions between life stages are thus environmentally driven; therefore, it is essential to understand the physiological responses of Alexandrium to differing environmental conditions. 
The manner in which phytoplankton respond to changes in environmental conditions determines their survival and growth. These physiological responses are governed by light, temperature, salinity and the availability of nutrients. Of these, nutrient concentrations in the field, specifically nitrogen, are likely to be the controlling factor for $A$. fundyense blooms in the western Gulf of Maine, since these populations are typically associated with low DIN concentrations $(<2 \mu \mathrm{M})$ in surface waters (Martorano, 1997). However, dinoflagellates are capable of vertical migration and thus can access deep nutrient pools below the thermocline. To understand A. fundyense dynamics, in the western Gulf of Maine, it is necessary to determine if strains from that region possess the behavior and physiology to access deep nutrients. Clearly, indicators or responses to nutrient deprivation need to be identified that are specific to Alexandrium.

Immunological Detection and Separation Techniques. As discussed previously, the harmful effects of many toxic algal blooms occur when the toxic species is a small fraction of the phytoplankton community. It is therefore difficult to determine the abundance or the physiology of a species, such as A. fundyense. In most cases, standard techniques for measuring chlorophyll, primary production, or nutrient uptake are not useful since they provide data for the entire planktonic community rather than the target species. To measure these parameters for an individual species in the field, that species must be separated from co-occurring organisms and detritus. These separation methods typically rely on the application of molecular "probes" for labeling and recognition, and procedures such as flow cytometric sorting and immunomagnetic separation for isolation. 
Flow cytometry has been used to study the physiology and ecology of phytoplankton species that have characteristic sizes and pigments. For example, two prokaryotes, Synechococcus and Prochlorococcus, are unique in size and fluorescence and thus can be enumerated rapidly with flow cytometry (Olson et al. 1990). However, larger size classes of phytoplankton which include toxic dinoflagellate species, cannot be discriminated as-easily based on size and autofluorescence alone. Therefore, antibody labeling procedures are now used to identify toxic phytoplankton species in the field (Vrieling et al. 1994; Vrieling et al. 1995; Vrieling et al. 1995a; Poulton, unpub. data). Flow cytometers also have the capability of sorting populations based on their size and fluorescence properties. It should be possible to obtain pure samples of a species for species-specific physiological studies, although this has not yet been attempted for HAB species.

A new antibody-based method has recently been developed that allows rapid and efficient isolation of a target species from a mixed assemblage. The antibodies are linked to small paramagnetic beads which attach to the target cells via an immuno-response, and the bead/cell complex is then removed from the sample with a magnet. Immunomagnetic separation was first used in the bio-medical industry for purification and characterization of tumor and lymphoid cells (Vrendenburg and Ball 1990; Wynick and Bloom 1990) and has also been used in the detection and isolation of DNA binding proteins (Haukanes and Kvam 1993). Only recently has this method been applied to phytoplankton (Aguilera et al. 1996). Aguilera et al. (1996) showed that Alexandrium fundyense could be separated from preserved cultures and field samples with success. However, the major motivation 
for developing this technique for $\mathrm{HAB}$ species is to obtain measurements of physiological parameters for a single species without the need for flow cytometry or manual single-cell isolations using a micropipet (e.g. Rivkin and Seliger 1981; Rivkin 1985). To date, preliminary measurements of ${ }^{14} \mathrm{C}$ uptake and chlorophyll and protein content have been made with some success on Alexandrium that were separated by magnetic beads from live and preserved laboratory cultures (Aguilera et al., in press). This method now needs to be adapted for field measurements, such that $A$. fundyense and other $\mathrm{HAB}$ species can be separated from other co-occurring organisms and detritus for physiological studies.

Physiology, Toxin Content and Composition. Once methods of detection and separation have been optimized for field studies it is necessary to determine the behavioral and biochemical effects of changing environmental conditions so that cell-specific measurements can be interpreted. Some of the physiological responses of phytoplankton to nutrient limitation appear to be common for many elements, for example, the photosynthetic apparatus. A decrease in chlorophyll content is a common response to limitation by essential elements such as nitrogen, phosphorus and iron (Kolber et al. 1988; Herzig and Falkowski 1989; Greene et al. 1991; Collier and Grossman 1992). The growth reduction induced by a limiting nutrient is due to impairment of an essential function. For example, carbon and nitrogen are essential for protein synthesis and phosphorus is an essential for cell division, nucleic acids and membranes. At present there are only a few methods and indicators that have been identified for nutrient limitation of phytoplankton species in the natural environment. For example, diagnostics such as glutamine:glutamate (GLN/GLU; 
Flynn et al. 1989; Flynn et al. 1996) and ferridoxin:flavodoxin (Fd index; Erdner et al. 1999), have been related to specific limitations or stresses (nitrogen and iron) in laboratory cultures and in some cases have been used to monitor changes in nutritional stress in the natural environment (LaRoche et al. 1996; Erdner and Anderson 1999). However, in most cases standard bulk analyses of the phytoplankton community, such as chlorophyll, primary production, or nutrient uptake, are not useful since they provide data for the entire planktonic community rather than an individual species, such as $A$. fundyense. Therefore, species-specific responses to nutrient deprivation ( $\mathrm{N}$ or $\mathrm{P}$ ) need to be identified.

One distinguishing feature of many Alexandrium species is the ability to produce toxins, specifically saxitoxin, which is a nitrogen-rich compound. Both toxin content (ie. pg total toxin per cell) and composition (relative or absolute concentrations of STX derivatives) has been shown to vary with nutritional conditions. Coinciding with the depletion of a limiting nutrient or an increase in environmental stress, the toxin content per cell and synthesis rate generally decreases in parallel to a general decline in cell metabolism. This has been observed for limiting nitrogen conditions and other sub-optimal environmental factors such as light and salinity (Hall 1982; Boyer et al. 1987; Ogata et al. 1987; Anderson et al. 1990; Flynn et al. 1994; Flynn et al. 1996; Matsuda et al. 1996). Two exceptions to these toxin dynamics patterns are phosphate limitation and low temperature conditions, where toxin content and production rates per cell increase significantly.

Given the widespread changes that are possible for toxin content, toxin composition was once thought to have remained constant despite environmental stress (Boyer et al. 1987; Anderson et al. 1990; Flynn et al. 1994; Sako et al. 1995; Matsuda et al. 1996). 
However, recently toxin composition under extreme growth-limited conditions (latestationary phase) or under progressive nitrogen limited conditions (continuous or semicontinuous culture) toxin composition has been shown to change (Boczar et al. 1988; Anderson 1990; Anderson et al. 1990b; MacIntyre et al. 1997). Furthermore, the changes in toxin composition that were observed differed between $\mathrm{N}$ and $\mathrm{P}$ limitation (Anderson et al 1990b). If specific patterns or trends in the toxin content and composition can be resolved for different nutrient limited conditions, then toxin content and or composition could be used as a biomarker specific to Alexandrium. This information, in combination with physiological data obtained using cell separation with immunomagnetic beads, may make it possible to determine the nutrient status of A. fundyense in field populations.

Outline of Dissertation: The overall objective of this thesis is to develop indicators or diagnostics of the physiological status of Alexandrium fundyense in the Gulf of Maine region. Specifically, what are the behavioral responses of $A$. fundyense to nutrient limitation (specifically nitrogen), and what are the physiological manifestations? Can we measure these indicators in naturally occurring populations?

In order to perform physiological measurements on A. fundyense cells from the field, methods for isolating cell populations are required. The second chapter focuses on the development or refining of two methods for identifying and separating A. fundyense from field samples, and describes attempts to measure the biochemical parameters of isolated cells. One approach, previously discussed, is the immunomagnetic separation method, which relies on an Alexandrium-specific monoclonal antibody that is coupled to 
magnetic beads and allows cells to be removed from a culture or mixed assemblage using a magnet (Aguilera et al. 1996). In Chapter 2, this method was optimized for field studies and tested to determine if live cells separated from field samples using magnetic beads could be used for biochemical analysis, such as C:N, chlorophyll $a$ and protein. The second approach examined was flow cytometry, for detection and separation of A. fundyense from field populations using the Alexandrium surface-specific monoclonal antibody in conjunction with different secondary fluorochromes.

In Chapter 3, the effects of nitrate stress on the physiology and behavior of a Casco Bay A. fundyense isolate were examined to elucidate potential indicators of nitrogen starvation and acclimation. Using laboratory mesocosms, batch and semi-continuous cultures nitrogen limited conditions and changes in physiology and behavior were identified, such as the presence or absence of diel vertical migration (DVM) or changes in C:N, chlorophyll $a$, toxin content and composition, carbohydrate and protein.

In Chapter 4, toxin content and compositional indicators of $\mathrm{N}$-limitation that were identified in chapter 3 were monitored during an A. fundyense spring bloom where ambient nitrogen concentrations (DIN) decreased rapidly over the course of the field season. I hypothesized that as nitrogen depletion (limitation) occurred during the field season, the toxin content and composition of $A$. fundyense within the plankton community will deplete and change in a predictable manner as the ambient $\mathrm{N}: \mathrm{P}$ ratio decreased. These changes were in fact observed, providing strong evidence that the bloom population became progressively limited by nitrogen through time. These results are very encouraging, since they indicate that it should be possible to determine the nutritional status of $A$. 
fundyense and other Alexandrium species using this approach. More studies are needed, however, to resolve some unexpected toxin composition changes observed in the field and mesocosm populations.

Overall, the development of physiological indicators and methods for cell identi- . fication and separation of Alexandrium fundyense will allow researchers to monitor natural Alexandrium blooms and identify and understand how changes in the environment such as nutrients, light, temperature and salinity effect their distribution and occurrence. Since toxin production is a distinguishing characteristic of $A$. fundyense and many other harmful algal bloom species, nutrient availability has a clear and significant influence on the variability in toxin production and composition. This thesis begins to elucidate more of the biochemical and cellular mechanisms and how limiting nutrients (specifically nitrogen) alters the cellular toxicity in the laboratory and in the coastal environment. Without more information about nutrient physiology of these cells during changing environmental conditions it is very difficult to assess the ecological role of toxins in population and community dynamics. 


\section{REFERENCES}

Aguilera, A., S. Gonzalez-Gil, B. A. Keafer and D. M. Anderson (1996). "Immunomagnetic separation of cells of the toxic dinoflagellate Alexandrium fundyense from natural plankton samples." Mar. Ecol. Prog. Ser. 143: 255-269.

Aguilera, A., B. A. Keafer, G. H. Rau, and D. M. Anderson (in press). "Immunomagnetic isolation of live and preserved Alexandrium fundyense cells: species-specific physiological, chemical, and isotopic analyses." Mar. Ecol. Prog. Ser.

Anderson, D. M., D. M. Kulis and B. J. Binder (1984). "Sexuality and cyst formation in the dinoflagellate Gonyaulax tamarensis: cyst yield in batch cultures." J. Phycol. 20: 418-425.

Anderson, D. M. and N. L. Lindquist (1985). "Time-course measurements of phosphorus depletion and cyst formation in the dinoflagellate Gonyaulax tamarensis." J. Exp. Mar. Biol. Ecol. 86: 1-13.

Anderson, D. M. (1989). "Toxin algal blooms and red tides: A global perspective." In: T. Okaichi, D. M. Anderson, T. Nemoto (eds.) Red Tides: Biology, Environmental Science, and Toxicology. pp. 11-16. Elsevier, Inc.

Anderson, D. M. (1990). Toxin variability in Alexandrium species. In: E. Graneli, B. Sundström, L. Edler and D. M. Anderson (eds.) Toxic Marine Phytoplankton. pp. 4151. Elsevier, Inc.

Anderson, D. M., D. M. Kulis, J. J. Sullivan, S. Hall and C. Lee (1990a). "Dynamics and physiology of saxitoxin production by the dinoflagellates Alexandrium spp." Mar. Biol. 104: 511-524.

Anderson, D. M., D. M. Kulis, J. J. Sullivan and S. Hall (1990b). "Toxin composition variations in one isolate of the dinoflagellate Alexandrium fundyense." Toxicon 28(8): 885-893.

Anderson, D. M. and A. W. White (1992). "Marine biotoxins at the top of the food chain." Oceanus 35: 55-61. 
Anderson, D. M. (1995). "Toxic red tides and harmful algal blooms: A practical challenge in coastal oceanography." Reviews of Geophysics, Supplement, July 1995 U.S. National Report to International Union of Geodesy and Geophysics: 1189-1200.

Anderson, D. M. (1997). "Bloom dynamics of toxic Alexandrium species in the northeastern U.S." Limnol. Oceanogr. 42(5, part 2): 1009-1022.

Boczar, B. A., M. K. Beitler, J. Liston, J. J. Sullivan and R. A. Cattolico (1988). "Paralytic shellfish toxins in Protogonyaulax tamarensis and Protogonyaulax catenella in axenic culture." Plant Physiol. 88: 1285-1290.

Boyer, G. L., J. J. Sullivan, R. J. Andersen, P. J. Harrison and F. J. R. Taylor (1987). "Effects of nutrient limitation on toxin production and composition in the marine dinoflagellate Protogonyaulax tamarensis." Mar. Biol. 96: 123-128.

Collier, J. L. and A. R. Grossman (1992). "Chlorosis induced by nutrient deprivation in Synechococcus sp. strain 7942: not all bleaching is the same." J. Bacteriol. 174: 4718-4726.

Doucette, G. J., A. D. Cembella and G. L. Boyer (1989). "Cyst formation in the red tide dinoflagellate Alexandrium tamarense (Dinophyceae): effects of iron stress." J. Phycol. 25: 721-731.

Erdner, D. L., N. M. Price, G. J. Doucette, M. L. Peleato and D. M. Anderson (1999). "Characterization of ferredoxin and flavodoxin as marker of iron limitation in marine phytoplankton." Mar. Ecol. Prog. Ser. 184: 43-53.

Erdner, D. L. and D. M. Anderson (1999). "Ferredoxin and flavodoxin as biochemical indicators of iron limitation during open-ocean iron enrichment." Limnol. Oceanogr. 44(7): 1609-1615.

Flynn, K. J., D. M. J. Dickson and O. A. Al-Amoudi (1989). "The ratio of glutamate:glutamine in microalgae; a biomarker for $\mathrm{N}$-status suitable for use at natural cell densities." J. Plankton Res. 11: 165-170.

Flynn, K., J. M. Franco, P. Fernandez, B. Reguera, M. Zapata, G. J. Wood and K. J. Flynn (1994). "Changes in toxin content, biomass and pigments of the dinoflagellate 
Alexandrium minutum during nitrogen refeeding and growth into nitrogen or phosphorous stress." Mar. Ecol. Prog. Ser. 111: 99-109.

Flynn, K., K. J. Jones and K. J. Flynn (1996). "Comparisons among species of Alexandrium (Dinophyceae) grown in nitrogen- or phosphorous-limiting batch culture." Mar. Biol. 126: 9-18.

Geraci, J. A., D. M. Anderson, R. J. Timperi, D. J. S. Aubin, G. A. Early, J. A. Prescott and C. A. Mayo (1989). "Humpback whales (Megaptera novaeangliae) fatally poisoned by dinoflagellate toxin." Can. J. Fish. Aquat. Sci. 46: 1895-1898.

Greene, R. M., R. J. Geider and P. G. Falkowski (1991). "Effect of iron limitation on photosynthesis in a marine diatom." Limnol. Oceanogr. 36: 1772-1782.

Hall, S. (1982). Toxins and toxicity of Protogonyaulax from the Northeast Pacific. PhD, University of Alaska, Fairbanks. p. 196.

Hallegraeff, G. M. (1993). "A review of harmful algal blooms and their apparent global increase." Phycologia 32: 79-99.

Haukanes, B. and C. Kvam (1993). "Application of magnetic beads in bioassays." Biotechnology 11: 60-63.

Herzig, R. and P. G. Falkowski (1989). "Nitrogen limitation in Isochrysis galbana (Haptophyceae). I. Photosynthetic energy conversion and growth efficiencies." J. Phycol. 25: 462-471.

Kolber, Z., J. Zehr and P. G. Falkowski (1988). "Effects of growth irradiance and nitrogen limitation on photosynthetic energy conversion in photosystem II." Plant Physiol. 88: 923-929.

LaRoche, J., P. W. Boyd, R. M. McKay and R. J. Geider (1996). "Flavodoxin as an in situ marker for iron stress in phytoplankton." Nature 382: 802-805.

MacIntyre, J. G., J. J. Cullen and A. D. Cembella (1997). "Vertical migration, nutrition and toxicity in the dinoflagellate Alexandrium tamarense." Mar. Ecol. Prog. Ser. 148: 201-216.

Martorano, C. A. (1997). Nutrient dynamics during blooms of Alexandrium spp. in the southwestern Gulf of Maine. MSc. University of New Hampshire, Durham. p.132. 
Matsuda, A., T. Nishijima and K. Fukai (1996). Effects of nitrogen deficiency on the PSP production by Alexandrium catenella under axenic cultures. In: T. Yasumoto, Y. Oshima and Y. Fukuyo. (eds.) Harmful and Toxic Algal Blooms. pp. 305-308. UNESCO.

Montoya, N. G., R. Akselman, J. Franco and J. I. Carreto (1996). Paralytic shellfish toxin and mackerel (Scomber japonicus) mortality in the Argentine sea. In: T. Yasumoto, Y. Oshima and Y. Fukuyo. (eds.) Harmful and Toxic algal Blooms. pp. 417-420. UNESCO.

Ogata, T., T. Ishimaru and M. Kodama (1987). "Effect of water temperature and light intensity on growth rate and toxicity change in Protogonyaulax tamarensis." Mar. Biol. 95: 217-220.

Olson, R. J., S. W. Chisholm, E. R. Zettler, M. a. Altabet and J. A. Dusenberry (1990). "Spatial and temporal distributions of prochlorophyte picoplankton in the North Atlantic Ocean." Deep-Sea Res. 37(6): 1033-1051.

Oshima, Y., S. I. Blackburn and G. M. Hallegraeff (1993). "Comparative study on paralytic shellfish toxin profiles of the dinoflagellate Gymnodinium catenatum from three different countries." Mar. Biol. 116: 471-476.

Rivkin, R. B. and H. H. Seliger (1981). "Liquid scintillation counting for ${ }^{14} \mathrm{C}$ uptake of single algal cells isolated from natural samples." Limnol. Oceanogr. 26: 780-784.

Rivkin, R. B. (1985). "Carbon-14 labeling patterns of individual marine phytoplankton from natural populations." Mar. Biol. 89: 135-142.

Sako, Y., N. Naya, T. Yoshida, C.-H. Uchida and Y. Ishida (1995). Studies on stability and heredity of PSP toxin composition in the toxic dinoflagellate Alexandrium. In: P. Lassus, G. Arzul, E. Erard, P. Gentien and C. Marcaillou. (eds.) Harmful Marine Algal Blooms. pp. 345-350. Lavoisier.

Shumway, S. E. (1990). "A review of the effects of algal blooms on shellfish and aquaculture." Journal of World Aquaculture Society 21: 65-104. 
Taylor, F. J. R. (1987). General group characteristics; special features of interest; short history of dinoflagellate study. In: F. J. R. Taylor (ed) The Biology of Dinoflagellates. pp. 1-23. Blackwell.

Vrendenburg, J. J. and E. D. Ball (1990). "Elimination of small cell carcinoma of the lung from human bone marrow by monoclonal antibodies and immunomagnetic beads." Cancer Research 50: 7216-7220.

Vrieling, E. G., W. W. C. Gieskes, W. J. M. v. Zeijl and M. Veenhuis (1994). "Detection of Gyrodinium aureolum in Dutch coastal waters by particle analysis based on immuno-flow cytometry." Netherland Journal of Aquatic Ecology 28(249-254).

Vrieling, E. G., W. W. C. Gieskes, T. W. M. Rademaker, G. Vriezekolk, L. Peperzak and M. Veehuis (1995). Flow cytometric identification of the ichthyotoxic dinoflagellate Gyrodinium aureolum in the central North Sea. In: P. Lassus, G. Arzul, E. Erard, P. Gentien and C. Marcaillou (eds.) Harmful Marine Algal Blooms. pp. 743-748. Lavoisier.

Vrieling, E. G., R. P. T. Koeman, L. Peperzak, K. Nagasaki and Y. Ishida (1995a). "Chattonella and Fibrocapsa (Raphidophyceae): first observation of potentially harmful, red tide organisms in the Dutch Wadden Sea." Netherland Journal of Sea Research 33: 183-191.

White, A. W., O. Fukuhara and M. Anraku (1989). Mortality of fish larvae from eating toxic dinoflagellates or zooplankton containing dinoflagellate toxins. In: T. Okaichi, D. M. Anderson and T. Nemoto. (eds.) Red Tides: Biology, Environmental Science and Toxicology. pp. 395-398. Elsevier Inc.

Wynick, D. and R. Bloom (1990). "Magnetic bead separation of anterior pituitary cells." Neuroendocrinology 52: 560-565. 


\section{CHAPTER 2}

IMMUNO-DETECTION AND SEPARATION OF THE TOXIC DINOFLAGELLATE ALEXANDRIUM FUNDYENSE FROM FIELD SAMPLES USING FLOW CYTOMETRY AND MAGNETIC BEADS 


\section{INTRODUCTION}

Currently, considerable research and monitoring is focused on toxic and harmful algal blooms (HABs). Typically, these blooms represent the growth and accumulation of a single species within a mixed phytoplankton assemblage - with the HAB species sometimes being dominant, but at other times representing only a small fraction of the plankton biomass (Anderson 1994). This latter situation presents problems for monitoring programs and field research, where the objective is to determine the presence, abundance and physiology of a particular toxic or harmful algal species in the environment. In most cases, standard biological oceanographic measurements (e.g., biomass, chlorophyll, primary production) are not useful for describing the target species since these provide information on the entire planktonic community. Methods are clearly needed that allow $\mathrm{HAB}$ species to be enumerated, separated, and characterized physiologically (Anderson 1995).

Species identification and enumeration have relied on microscopic observations for decades. The separation of cells for species-specific measurements such as primary productivity has been attempted using tedious, single cell microscope isolations (Rivkin and Seliger 1981; Rivkin et al. 1984; Rivkin 1985; Graneli et al. 1997). However, application of this approach is limited not only by the need to visually distinguish between species to be isolated, which is often difficult, but also by the time required for manual isolations. Generally, this method is most effective for biochemical assays where relatively small numbers of cells (i.e., 50-100) are required. 
Over the last decade, new methods for identification, enumeration and separation have been developed that rely on "molecular probes" for labeling and cell recognition (Anderson 1995). These can be antibodies (monoclonal or polyclonal) that target unique cell surface antigens, or oligonucleotides (small nucleic acid probes) that easily penetrate the cell and bind to specific regions of a cell's DNA or RNA. Cell-surface monoclonal or polyclonal antibodies and oligonucleotide probes (typically targeting ribosomal RNA) have been developed for a number of toxic algal species (Hiroishi et al. 1988; Anderson et al. 1993; Bates et al. 1993; Sako et al. 1993; Mendoza et al. 1994; Vrieling et al. 1994; Miller and Scholin 1996; Scholin et al. 1996; Chang et al. 1999, Peperzak et al. 2000). The use of these new labeling methods, sometimes for manual microscope counting and sometimes in an automated fashion using flow cytometry, is changing the manner in which phytoplankton communities are characterized.

Flow cytometry has been used to study the physiology and ecology of phytoplankton species that have unique sizes and pigments (Chisholm et al. 1986; Olson et al. 1988). However, larger size classes of phytoplankton, which include many toxic or harmful dinoflagellate species, often cannot be discriminated from other phytoplankton species based on size and autofluorescence alone. Therefore, molecular probes, specifically antibodies, are now used to tag or highlight toxic species for better discrimination (Hofstraat et al. 1994; Vrieling et al. 1994; Vrieling et al. 1995). Some flow cytometers have cell sorting devices that allow physical separation of selected cells (gated cell populations) from the main sample stream. This separation is based on the cell's size, autofluorescence, or immunofluorescence properties. In addition to microscopic isola- 
tions, flow cytometric sorting has been used to quantify primary production, nitrogenspecific uptake rates, and biomass on different groups of phytoplankton (eucaryotic vs. prochlorphytes) and single cells (Phinney 1983; Rivkin et al. 1986; Lipschultz 1995; Li 1994; and Li 1997). Theoretically, it should be possible to obtain a pure sample of a particular species for physiological studies using immunofluorescence as a means of cell detection, but again, this approach is limited by the time required for sorting and the number of cells required for particular biochemical measurements.

Recently, another antibody-based method was described that allows rapid and efficient isolation of a target species from a mixed plankton assemblage (Aguilera et al. 1996). In this method, cell surface antibodies are linked to small paramagnetic beads that attach to the target cells during treatment. The bead/cell complex is then removed from the sample using a magnet. Immunomagnetic separation is used widely in the biomedical industry, such as in the detection and isolation of DNA-binding proteins (Haukanes and Kvam 1993). When this method was applied to marine phytoplankton communities (Aguilera et al. 1996), it was possible to successfully isolate Alexandrium fundyense from natural plankton samples. Subsequently, the method has been adapted for measurements of ${ }^{14} \mathrm{C}$ uptake, chlorophyll $a$, RNA, DNA and protein content of live $A$. fundyense cells in laboratory culture (Aguilera et al. in press).

In this paper, we examine and compare two antibody-based detection and separation methods on natural field assemblages. The first uses immunofluorescence and flow cytometry to identify, enumerate, and separate the toxic dinoflagellate Alexandrium fundyense from co-occurring organisms and detritus. The second approach uses an im- 
munomagnetic bead separation method, previously tested by Aguilera et al. (in press) on laboratory cultures of A. fundyense. However, in this study, we describe a modified separation method that uses larger volumes that makes it possible to separate and biochemically characterize field populations of $A$. fundyense.

\section{MATERIALS AND METHODS}

\section{Flow Cytometry Studies}

Cultures and field sample preparation. Cultures of Alexandrium fundyense (strain GTCA28) were maintained in modified f/2 medium (Guillard 1975) made with $0.2 \mu \mathrm{m}$ filtered Vineyard Sound seawater (VSW - refer to Table 2.1 for all abbreviations and acronyms). The $\mathrm{f} / 2$ medium was modified by an increase in $\mathrm{Na}_{2} \mathrm{SeO}_{3}$ and a decrease in $\mathrm{CuSO}_{4} 5 \mathrm{H}_{2} \mathrm{O}$ to final concentrations of $10^{-8} \mathrm{M}$. Cultures were grown at $20{ }^{\circ} \mathrm{C}$ under a 14:10 h L:D regime (ca. $200 \mu \mathrm{mol}$ photons $\mathrm{m}^{-2} \mathrm{sec}^{-1}$ using fluorescence lamps). Additional dinoflagellate cultures of equivalent size (15-35 $\mu \mathrm{m}$ ) (Scrippsiella trochoidea; strain SA10, Gonyaulax spinifera; strain GSPP01, Prorocentrum micans; strain PTPP01, and Gyrodininum uncatenum; GUPP01) were grown under similar conditions. Each culture was harvested in exponential phase and preserved using borate-buffered formalin, $5 \%(\mathrm{v} / \mathrm{v})$ final concentration, and stored at $4{ }^{\circ} \mathrm{C}$ in the dark. Subsamples of the $A$. fundyense culture were stored at both $4{ }^{\circ} \mathrm{C}$ and $-80{ }^{\circ} \mathrm{C}$ in the dark to test long-term storage effects. Samples for cell abundance were preserved using a Utermohl's solution 
(Utermöhl 1958) and cell concentrations were determined microscopically (100 x) using a Sedgewick-Rafter counting chamber.

Table 2.1 List of abbreviations and acronyms.

\begin{tabular}{ll}
\hline Abbreviation & Definition \\
\hline BP & band pass \\
BSA & bovine serum albumin \\
chl $a$ & chlorophyll $a$ \\
CHO & carbohydrate \\
DMEM & Dulbecco's Modified Eagle's Medium \\
FCS & fetal calf serum \\
FITC & fluorecein isothiocyanate (green fluorochrome) \\
FLS & forward light scatter \\
HAB(s) & harmful algal bloom(s) \\
GAM & goat anti-mouse \\
IgG & Immunoglobulin protein, subclass $\mathrm{G}_{1}$ \\
IMBS & Immuno-magnetic bead separation \\
LP & long pass \\
MAb & monoclonal antibody or antiserum \\
MMP & mouse myloma protein \\
MPC & magnetic particle concentrator \\
NGS & normal goat serum \\
NSS & normal sheep serum \\
PBS & phosphate buffered saline \\
PE & phycoerythrin (orange fluorochrome) \\
RFU & relative fluorescence unit \\
SNN & signal to noise ratio \\
SaM & sheep anti-mouse \\
SSC & side scatter \\
\hline
\end{tabular}

On occasion, field samples were spiked with $A$. fundyense cells to ensure adequate biomass for experiments. Samples were collected from Eel Pond, Woods Hole, MA in the spring using a $20 \mu \mathrm{m}$ mesh plankton net. Each tow was filtered through a series of mesh sieves to isolate the $64-20 \mu \mathrm{m}$ fraction and then concentrated and preserved using buffered formalin as above and stored at $4{ }^{\circ} \mathrm{C}$ in the dark. Each sample was examined under the light microscope to ensure that no Alexandrium cells were present. In all cases 
Alexandrium spp. were not observed. Spiked field samples were then prepared by adding 10,000 cells of preserved $A$. fundyense culture and 5,000 cells of the other dinoflagellate species to $1 \mathrm{ml}$ of a concentrated Eel Pond sample. Samples were also collected for flow cytometry from Perch Pond, Falmouth, MA in the spring, 1996 and from Hens Cove in Casco Bay, ME during the spring of 1998, when Alexandrium was present in the water column. For each field sample, 12 liters of seawater was concentrated through sieves to obtain the $64-20 \mu \mathrm{m}$ fraction. Duplicate field samples were resuspended into separate 15 $\mathrm{ml}$ conical centrifuge tubes containing cooled $\left(10-15{ }^{\circ} \mathrm{C}\right)$ sterile-filtered seawater, preserved as above, and stored at both $4{ }^{\circ} \mathrm{C}$ and $-80^{\circ} \mathrm{C}$ for short-and long-term storage, respectively.

Monoclonal Antibody (MAb). Prior to antibody labeling, the monoclonal primary antiserum (MAb: M8751-1) directed against the cell surface of Alexandrium tamarense was obtained from Y. Sako, Kyoto, Japan (Adachi et al. 1993; Sako et al. 1993). This antibody has been shown to cross-react with both $A$. fundyense and $A$. tamarense from the Gulf of Maine (Anderson unpubl.). This MAb, which is of the immunoglobulin (Ig) $\mathrm{G}_{1}$ subclass of Ig proteins, was obtained from the M-8751-1 hybridoma culture supernatant that contained 20\% fetal calf serum (FCS, Rehatuin) in Dulbecco's Modified Eagle's Medium (DMEM). The MAb supernatant was aliquoted into smaller volumes and frozen at $-20^{\circ} \mathrm{C}$ until use. 
Immunochemical staining protocol. Culture and field samples were pipetted into separate $1.5 \mathrm{ml}$ microcentrifuge tubes. For each secondary or tertiary fluorochrome that was tested duplicate samples were prepared one each for a positive and negative labeled sample. Each sample was washed once in a $1.5 \mathrm{ml}$ microcentrifuge tubes using $1 \mathrm{ml} 0.02 \mathrm{M}$. phosphate-buffered saline (PBS) by centrifugation (ca. $3000 \mathrm{xg}$ ) for 4 min in order to remove the preservative and seawater. The cell pellets were incubated in the dark at 25 ${ }^{\circ} \mathrm{C}$ (room temperature) for 30 mins with $1 \mathrm{ml}$ of blocking agent, $0.02 \mathrm{M}$ PBS containing 5\% (v/v) Normal Goat Serum (NGS; Sigma Chemical Co.). The culture and field samples were then centrifuged and aspirated. Afterwards, $100 \mu \mathrm{l}$ of primary $\left(1^{\circ}\right) \mathrm{M}-8751-1$ monoclonal antiserum (MAb) was added to the positive labeled samples, whereas $100 \mu \mathrm{l}$ of a 1:100 dilution of purified mouse myloma protein (MMP; Sigma Chemical Co.) of the $\mathrm{IgG}_{1}$ subclass was added as a replacement for the specific MAb M-8751-1 to each negatively labeled tube as a sample control. All treatments were incubated at $25^{\circ} \mathrm{C}$ for $30 \mathrm{~min}$ in the dark. Samples were washed 3 times with $1 \mathrm{ml}$ PBS containing $0.5 \%$ NGS and resuspended using one of the following dilutions of secondary antiserum: goat antimouse IgG fluorecein isothiocyanate (FITC; Molecular Probes, Inc. [Eugene, Oregon], F2761; 1:300; v/v with 5\% NGS/PBS), goat anti-mouse IgG phycoerythrin (PE; Molecular Probes, Inc.; 1:200; v/v with 5\% NGS/PBS), or goat anti-mouse biotin (GAM-biotin; Molecular Probes, Inc.; 1:200; v/v with 5\% NGS/PBS). The samples were incubated with the secondary antisera at $25^{\circ} \mathrm{C}$ for $30 \mathrm{~min}$. in the dark. After three wash steps with $1 \mathrm{ml} 0.02 \mathrm{M}$ PBS containing $0.5 \%$, the samples labeled with either goat anti-mouse FITC or PE as a secondary fluorochrome, were stored in $1 \mathrm{ml} 0.02 \mathrm{M}$ PBS in $0.5 \%$ NGS at 
$4{ }^{\circ} \mathrm{C}$ until flow cytometric analysis. However, the samples that were labeled with biotin (goat anti-mouse biotin as a secondary antiserum) were resuspended for a third time using an avidin signal enhancer containing a 1:200 (v/v with 5\% NGS in 0.02 M PBS) dilution of either "neutralite" avidin-FITC (Molecular Probes, Inc.) or "neutralite" avidinPE (Molecular Probes, Inc.). All tubes were incubated at $25^{\circ} \mathrm{C}$ for $30 \mathrm{~min}$ in the dark then washed 3 times with $1 \mathrm{ml} 0.5 \%$ NGS in $0.02 \mathrm{M}$ PBS. All samples were stored at $4{ }^{\circ} \mathrm{C}$ in the dark until flow cytometric analysis (within 24 hours).

Flow cytometry. Flow cytometric analysis was performed using either a Becton Dickinson FACS-Vantage housed at the MIT Flow Cytometry Facility (Massachusetts Institute of Technology, Cambridge, MA) or a Becton Dickinson FACSCalibur located at the Woods Hole Oceanographic Institution (Woods Hole, MA). For both instruments, a 488 nm argon laser was used for both FITC and PE excitation. The FACS-Vantage laser was a $100 \mathrm{~mW}$ Coherent Innova 305 where as the FACSCalibur used a $15 \mathrm{~mW}$ laser for excitation. Emissions detection of the fluorochromes or natural pigments was obtained using a 530 bandpass filter (BP), $575 \mathrm{BP}$, and 640 longpass LP filters for green (FITC), orange (PE), and red (chlorophyll) fluorescence, respectively. Detectors for forward scatter (FLS) and side scatter (SSC) were also used to collect information relative to the size, composition and cell density.

Prior to running on the flow cytometer, 5000-10 $\mu \mathrm{m}$ EPICS DNA Check fluorospheres (Coulter Corp.) were added to each antibody-labeled sample and transferred from the $1.5 \mathrm{ml}$ microcentrifuge tube to plastic vials. Each sample was run to near dryness 
with occasional vortexing to insure that the maximum number of cells were analyzed and that the sample was evenly mixed throughout the run. Five flow cytometric parameters (green fluorescence, orange fluorescence, red fluorescence, FLS and SSC) were collected on a logarithmic scale, whereas cell density information was collected linearly. Flow cytometric data are typically presented in the form of scatter plots, in which two parameters are plotted against each other. The fluorescence information derived from the flow cytometer is in relative fluorescence units (RFU). A variety of scatter plots were examined to determine the best representation that allowed for optimal separation using secondary and tertiary fluorochromes (green-FITC or orange-PE). Once the target population consisting of $A$. fundyense cells was identified, the cells were isolated from the culture or field samples via cell sorting, and examined microscopically (100 x) for positive identification.

\section{Immunomagnetic bead separation}

Culture and Field Sample Preparation. Cultures of Alexandrium fundyense (strain CB307 ) were maintained in both modified (as above) replete $f / 2$ medium and low-nitrate $f / 2$ (50 $\mu \mathrm{M}$ - initial concentration). All cultures were grown and harvested as described previously. Field samples were collected from Eel Pond, MA using a Rule 2000 submersible bilge pump operating between $20-25 \mathrm{~L} \mathrm{~min}^{-1}$. Approximately $210 \mathrm{~L}$ of seawater were passed through a $20 \mu \mathrm{m}$ plankton net and then sieved to obtain the $64-20 \mu \mathrm{m}$ fraction. The samples were resuspended in $50 \mathrm{ml}$ conical centrifuge tubes using $4{ }^{\circ} \mathrm{C}$ sterile 
filtered seawater. Field samples were stored on ice or at $4{ }^{\circ} \mathrm{C}$ and used within $1-2$ hours. For all cell separations, live Alexandrium cultures and field samples were used.

Immunochemical labeling and cell separation. For magnetic bead separation, an "indirect" method of bead attachment was used, modified from Aguilera et al. (1996) (see Figures 2.1 and 2.2). The "direct" method of bead attachment as shown in Figure 2.1 proved not to be effective in cell recovery as described by Aguilera et al. (1996). Samples were prepared using 2-3 ml of concentrated field sample (equivalent to $15-30 \mathrm{~L}$ of seawater) and 20,000-100,000 live cultured $A$. fundyense cells in individual $15 \mathrm{ml}$ conical centrifuge tubes. After the cells were added to both the positive MAb bead treatment (with primary MAb) tubes and the negative bead controls (no MAb added) the seawater or culture media was removed by aspiration after centrifugation for $2-3$ mins at 3000 $4000 \mathrm{rpm}(\sim 1000 \mathrm{x} \mathrm{g})$. Each sample was then incubated for $30 \mathrm{~min}$ on ice or at $4^{\circ} \mathrm{C}$ with $2 \mathrm{ml}$ of blocking agent, $0.1 \mathrm{M}$ PBS containing 3\% (v/v) Normal Sheep Serum (NSS; Sigma Chemical Co.). To avoid osmotic shock, the low salinity of the $0.1 \mathrm{M}$ PBS was modified to $25 \mathrm{ppt}$ by tripling the $\mathrm{NaCl}$ concentration. This $0.1 \mathrm{M}$ PBS solution was used throughout the immunomagnetic bead separation procedure.

After blocking, $150 \mu \mathrm{l}$ monoclonal antiserum (20\% FCS - DMEM media, clone M-8751-1) was added to each positive bead treatment tube targeted for magnetic bead separation. No primary antibody was added to negative bead control tubes, therefore, preventing cell separation from occurring. Three different negative bead controls were analyzed depending on whether bead separation was for cultured cells only or field sam- 
ples spiked with Alexandrium cells. The different negative bead controls (no primary MAb added) were as follows: beads only, beads + Alexandrium cells, and beads + Alexandrium cells + field sample. These controls were used as blanks or background controls for biochemical calculations and analyses of Alexandrium cells separated from the positive bead treatments (see Biochemical Calculations and Analysis in Results section). After the addition of the MAb to the positive bead treated cell samples, all samples were incubated for $1 \mathrm{hr}$ on ice or at $4{ }^{\circ} \mathrm{C}$, centrifuged for 2-3 mins ( 1000x g), and washed three times with 0.1 M PBS. After the final wash, all tubes were re-suspended to $10 \mathrm{ml}$ and $1 \mathrm{ml}$ was removed for cell counting to estimate the number of target cells present before bead attachment. The tubes were centrifuged one final time and the media aspirated to $2 \mathrm{ml}$. Prior to bead attachment, the M-280 sheep anti-mouse IgG magnetic beads (M280 SaMi; Dynal, Inc. New York, USA) were washed three times using $1 \mathrm{ml} 0.1 \mathrm{M}$ PBS using the Dynal Magnetic Particle Concentrator (MPC-6) to remove the sodium azide preservative and any unbound antibody. Stock concentration of the Dynal M-280 SaM beads contained ca. $6-7 \times 10^{7}$ beads per $\mathrm{ml}$. Each bead had a spherical diameter of 2.8 $\mu \mathrm{m}$.

Figure 2.1. Description of direct vs. indirect immunomagnetic bead labeling adapted from Aguilera et al. (1996). 


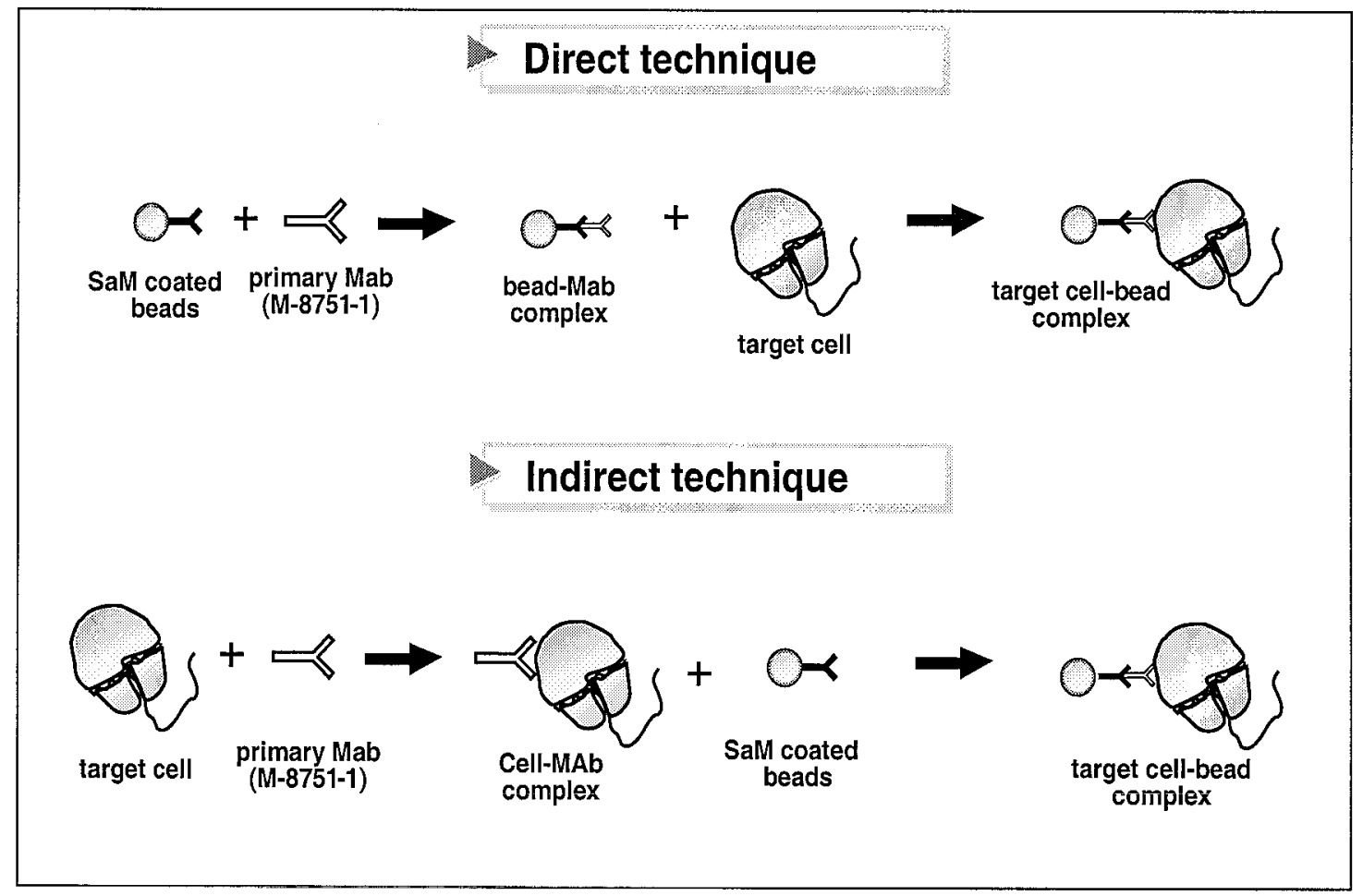


Figure 2.2. Immunomagnetic bead method flow diagram. 


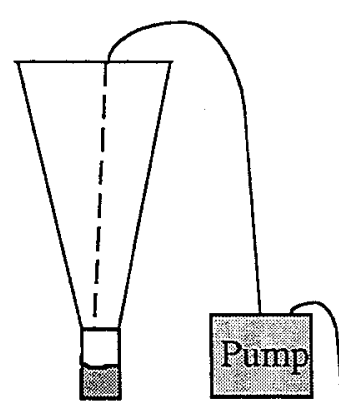

1. Collect Field Sample

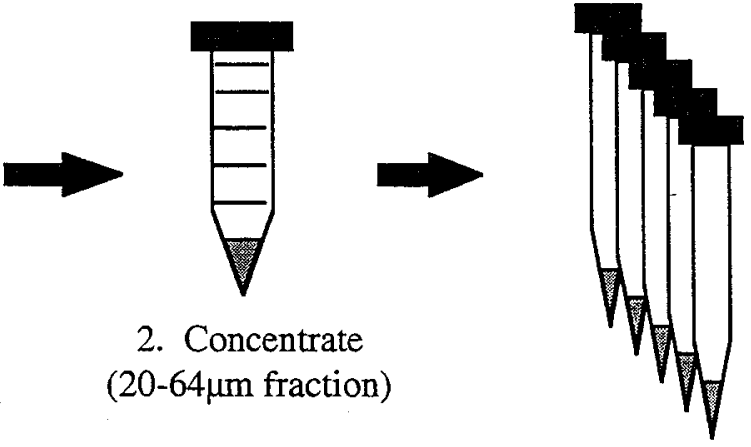

3. Distribute ( $15 \mathrm{ml}$ tubes)
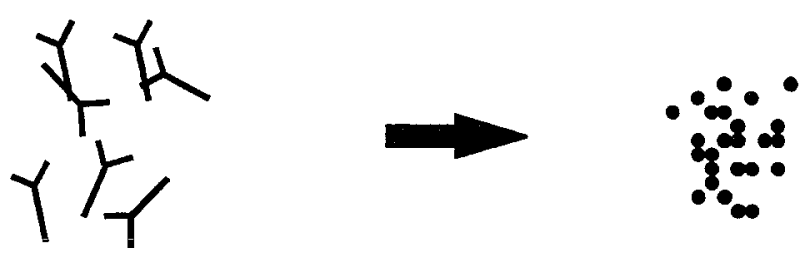

4. ADD Cell Specific MAb

5. Wash \& Add Dynal M-280 SaM magnetic beads

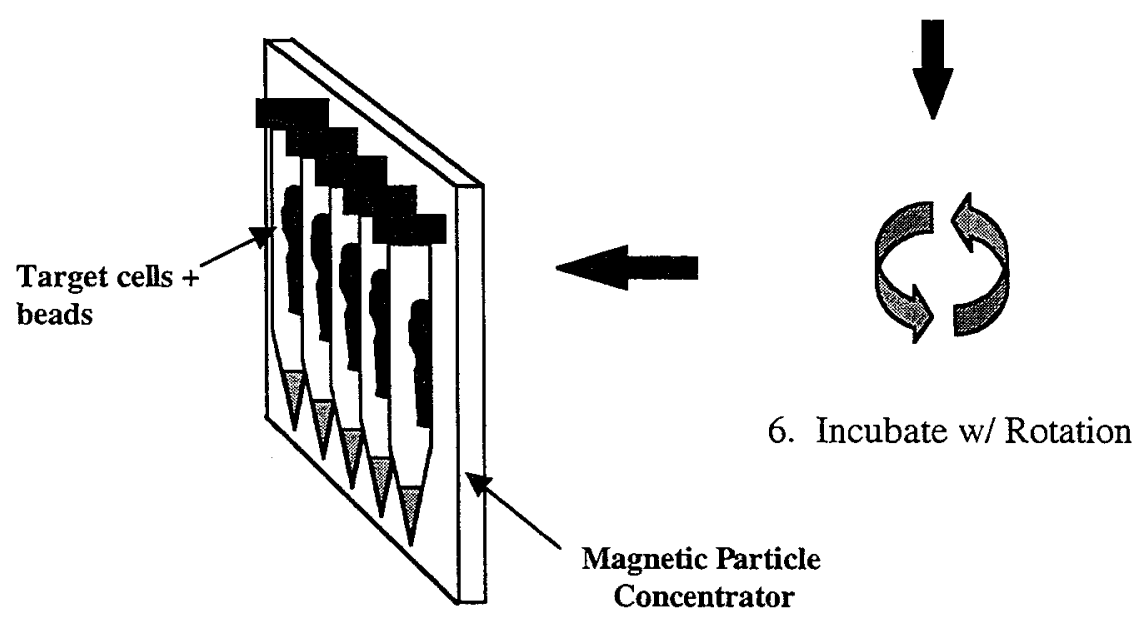

7. Magnetically Separate 
To complete the cell isolation, an appropriate concentration of beads, ca. $1.0 \times 10^{7}$ beads, (see Optimization of cell recovery section below) were added to each tube that required immunomagnetic separation. All tubes with beads were incubated at $4{ }^{\circ} \mathrm{C}$ for $1 \mathrm{~h}$ with rotation on a Labquake shaker that kept the beads and cells in constant suspension to ensure efficient binding of the beads to the antibody labeled target cells. Afterwards, the target cell-bead complexes were isolated using 2 large magnetic particle concentrators (15 ml/50 ml Tube Separator, PE Biosystems, MA, USA). After 15 mins, the supernatant was carefully aspirated to a final volume of $2 \mathrm{ml}$. All the supernatant was not removed so that the bead-cell complexes that were washed down the side of the tube due to surface tension were not aspirated. Aspiration was slow but steady, so that the bead-cell complexes were not dislodged from the side of the tube closest to the magnet. All samples were resuspended in $8 \mathrm{ml}$ of $0.1 \mathrm{M}$ PBS (final volume $10 \mathrm{ml}$ ) and magnetic separation was repeated two times. After the final separation wash step, all tubes were resuspended to a final volume of $9 \mathrm{ml}$ and $1 \mathrm{ml}$ aliquots were removed for cell counts to determine the concentration of cells after magnetic separation. The remaining $8 \mathrm{ml}$ were used for biochemical measurements.

Prior to performing an immunomagnetic bead separation, cultured cell controls were filtered from the original Alexandrium culture used in each experiment to obtain the initial concentration of chl $a$, protein, carbohydrate, carbon and nitrogen per cell. In addition filter controls (precombusted glass fiber filters with PBS) were also analyzed for each biochemical determination. 
Optimization of cell recovery. To achieve optimal cell separation from cultures or field samples, different bead concentrations, incubation times and the number of wash steps were varied in order to maximize binding efficiency but minimize bead attachment to the non-target field population. Many different bead:cell ratios were examined.

Determination of recovery percentage. A $1 \mathrm{ml}$ sub-sample was removed from each experimental treatment before and after bead attachment and preserved with formalin as above. The $1 \mathrm{ml}$ subsamples were diluted and subsequent $1 \mathrm{ml}$ samples were counted in duplicate microscopically (200x) using a $1 \mathrm{ml}$ Sedgewick-Rafter counting chamber. The cell counts before and after bead attachment were compared to determine the recovery percentage. Some cell loss is unavoidable during the washing steps.

In order to count Alexandrium spp. cells in the spiked field samples, immunofluorescent techniques similar to those used for flow cytometry were used. Samples were first incubated with the M-8751-1 MAb, washed twice with $1 \mathrm{ml} 0.05 \%$ NSS in PBS, followed by $100 \mu \mathrm{l}$ 1:300 dilution goat anti-mouse (GAM) IgG secondary antibody conjugated to FITC (green fluorochrome). For the samples containing Alexandrium spp. that had already been exposed to the primary MAb (positively labeled samples), only the addition of $100 \mu \mathrm{l}$ of 1:300 FITC GAM secondary antibody was required. After incubating, the labeled samples were washed three times with $1 \mathrm{ml} 0.05 \%$ NSS in PBS with centrifugation. The fluorescently labeled cells (Alexandrium) that contained chlorophyll (red fluorescence) were enumerated using a Sedgewick-Rafter counting chamber using a Zeiss 
Axioskop epifluorescent microscope $(200 \mathrm{x})$ with a FITC filter set (excitation $=\mathrm{BP} 450$ 490, emission $=$ LP 520).

Analytical Determinations. Magnetically separated samples were collected to determine chl $a$, particulate $\mathrm{C}$ and $\mathrm{N}$, protein, and carbohydrate. For the determination of chl $a$, samples were filtered onto Whatman GF/F glass fiber filters and extracted in $10 \mathrm{ml}$ of ice-cold $90 \%$ acetone at $-20{ }^{\circ} \mathrm{C}$ for $24-48 \mathrm{~h}$. Chl a concentrations, corrected for pheopigments, were determined using a Turner Designs fluorometer (Strickland and Parsons 1972) calibrated with pure chl $a$ (Sigma Chemical Co.).

Samples for particulate $\mathrm{C}$ and $\mathrm{N}$, protein and carbohydrate measurements before and after magnetic bead separation (hereafter "bead treatment") were filtered onto $25 \mathrm{~mm}$ pre-combusted $\left(4-6 \mathrm{~h} @ 400^{\circ} \mathrm{C}\right)$ Whatman GF/F glass fiber filters and stored in liquid nitrogen. For particulate $\mathrm{C}$ and $\mathrm{N}$, some samples were sieved onto a $20 \mu \mathrm{m}$ mesh after bead treatment to remove unattached beads before filtering. Retained cells were washed off the mesh into $8 \mathrm{ml}$ of $0.1 \mathrm{M}$ PBS. All particulate $\mathrm{C}$ and $\mathrm{N}$ samples were dried at $60^{\circ} \mathrm{C}$ overnight and stored in a desiccator prior to analysis on a Perkin Elmer $2400 \mathrm{CHN}$ analyzer, using acetanilide as a standard. As a blank, triplicate $8 \mathrm{ml} 0.1 \mathrm{M}$ PBS samples were filtered onto precombusted GF/F glass fiber filters and run simultaneously with the other samples, and stored in liquid nitrogen.

For protein analysis, a heated biuret folin protein assay was used, based on Lowry et al. (1951) as modified by Dorsey et al. (1978). Briefly, filtered samples were added to $13 \times 100 \mathrm{~mm}$ borosilicate glass screw-capped tubes with polypropylene caps (Fisher Sci- 
entific Co., Pittsburgh PA, USA) and resuspended in $300 \mu \mathrm{l} 0.1 \mathrm{~N}$ sodium hydroxide solution and $1.8 \mathrm{ml}$ of combined reagent (alkaline cupric tartrate). Each tube was then capped, vortexed and heated at $95-100{ }^{\circ} \mathrm{C}$ for $100 \mathrm{~min}$. Afterwards, $180 \mu \mathrm{l}$ of a $1 \mathrm{~N}$ Folin phenol reagent (Sigma Chemical Co.) was added to form a blue color. The tubes were vortexed and cooled in a $10^{\circ} \mathrm{C}$ water bath for $10 \mathrm{~min}$. After cooling, the tubes sat a room temperature for $1 \mathrm{~h}$ and were then read at $660 \mathrm{~nm}$ using disposable $1 \mathrm{~cm}$ acrylic cuvettes in a Shimadzu UV-160 spectrophotometer (Shimadzu Corp. Japan). Bovin serum albumin (BSA; Sigma Chemical Co.) with precombusted glass fiber filters was run simultaneously as a protein standard.

The carbohydrate analysis was adapted from Dubois et al. (1956). For the analysis, $400 \mu \mathrm{l}$ of nanopure (Millipore) water was added to filtered samples in $13 \times 100 \mathrm{~mm}$ disposable borosilicate glass screw-capped tubes with polypropylene caps. Standards were prepared as a dextrose dilution series $(400 \mu \mathrm{g} / \mathrm{ml})$ with precombusted glass fiber filters. To both the sample and standard tubes, $500 \mu 1$ of phenol $(5 \% \mathrm{w} / \mathrm{v}$ in water) was added and vortexed. Afterwards $2 \mathrm{ml}$ of concentrated sulfuric acid was added slowly to each tube, which was then capped and vortexed in a fume hood. All of the tubes were heated in a $90-100^{\circ} \mathrm{C}$ water bath for 1 hour. The samples were read on a Shimadzu UV160 spectrophotometer at the maximum absorbance of the highest standard $(485-490 \mathrm{~nm})$ using $1 \mathrm{~cm}$ disposable acrylic cuvettes (Fisher Scientific Co. Pittsburgh, PA, USA). Statistical comparisons were made using a Student's t-test to compare the means (of the biochemical analyses) among the different beads treatments. 


\section{RESULTS}

\section{Flow Cytometry}

Immunofluorescent staining. In both cultured and mixed field assemblages, Alexandrium fundyense was successfully distinguished from co-occurring organisms, including other dinoflagellates of equivalent size such as Scrippsiella trochoidea, Gonyaulax spinifera, Prorocentrum micans, and Gyrodininum uncatenum. This was only possible, however, if multiple parameters were used for discrimination - in particular, the fluorescence associated with antibody labeling (green - FITC or orange - PE) and the natural chlorophyll fluorescence (red fluorescence) of the cells. Figure 2.3 shows two typical scatter plots comparing two spiked field samples, a negative MMP-treated and a positive MAb-treated sample. In the MMP treated sample both the non-target and target Alexandrium cells comprise one control cell population, where as in the MAb-treated sample the target Alexandrium cells are readily distinguished from the non-target dinoflagellates using green FITC fluorescence.

Figure 2.3. Flow cytometric 2-dimensional scatter plots showing green-FITC fluorescence and red-chlorophyll fluorescence of field samples spiked with non-target dinoflagellates and Alexandrium cells (see Methods). A MMP treated negative control sample containing non-target dinoflagellates and Alexandrium cells is shown in panel A. Using a positive MAb treated spiked field sample, FITC-MAb labeled Alexandrium cells were readily distinguished from non-target dinoflagellates as shown in Panel B. The 3dimensional plots show the relative abundance of the different cell populations identified. 

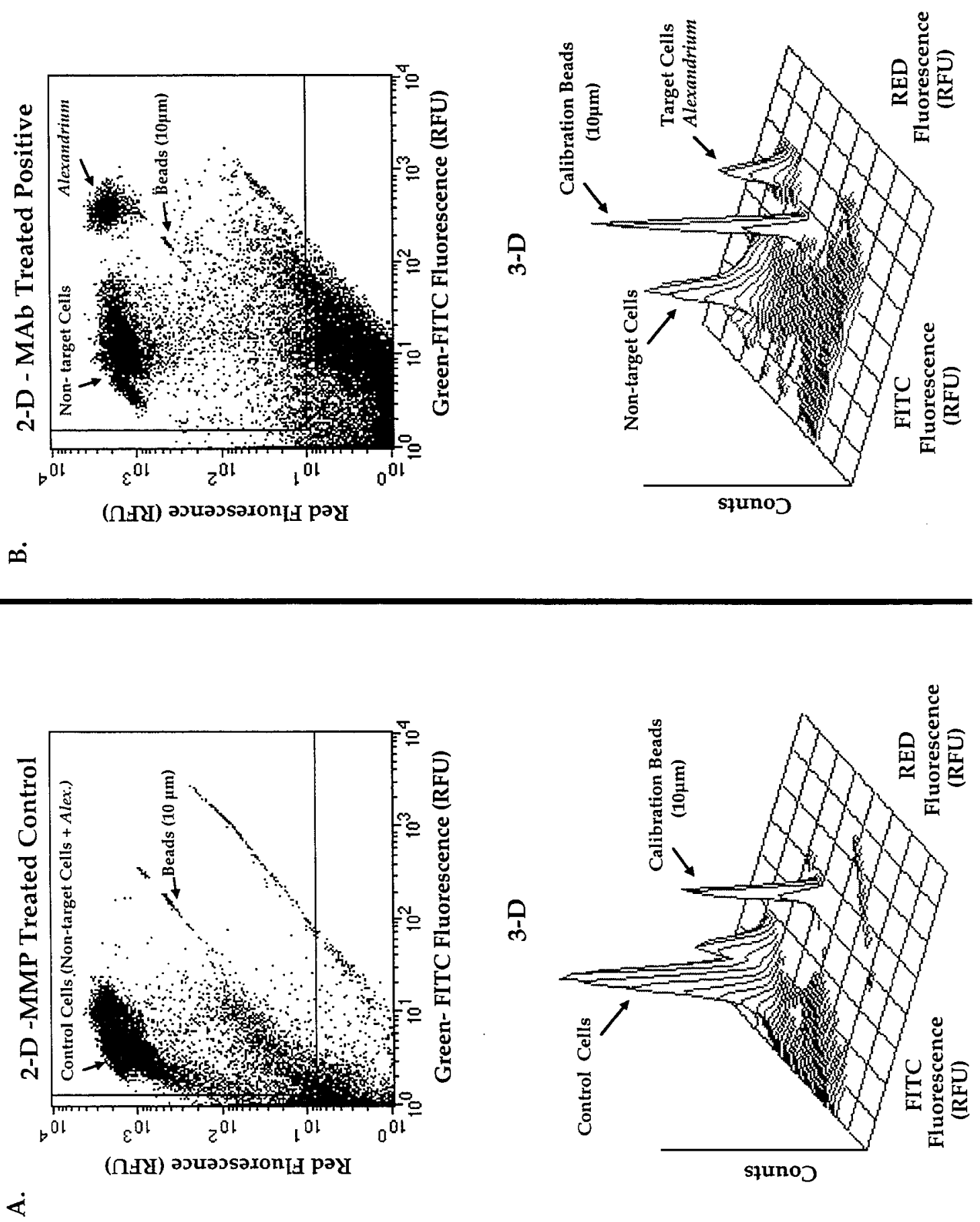
Figure 2.4. Flow cytometric scatter plots using different scattering and fluorescence parameters of a positive MAb treated field sample spiked with non-target dinoflagellates and Alexandrium (black dots $=$ non-target population; grey dots $=$ Alexandrium cells) . The FITC-MAb labeled Alexandrium cells were not separated when using forward light scatter and red-chlorophyll fluorescence(Panel A). Better separation was observed when using forward light scatter vs. green-FITC fluorescence (Panel B). However, optimal separation of FITC-MAb labeled Alexandrium cells was achieved when using the greenFITC fluorescence and red-chlorophyll fluorescence (Panel C). The FITC-MAb Alexandrium target populations were identified via flow cytometric cell sorting. 

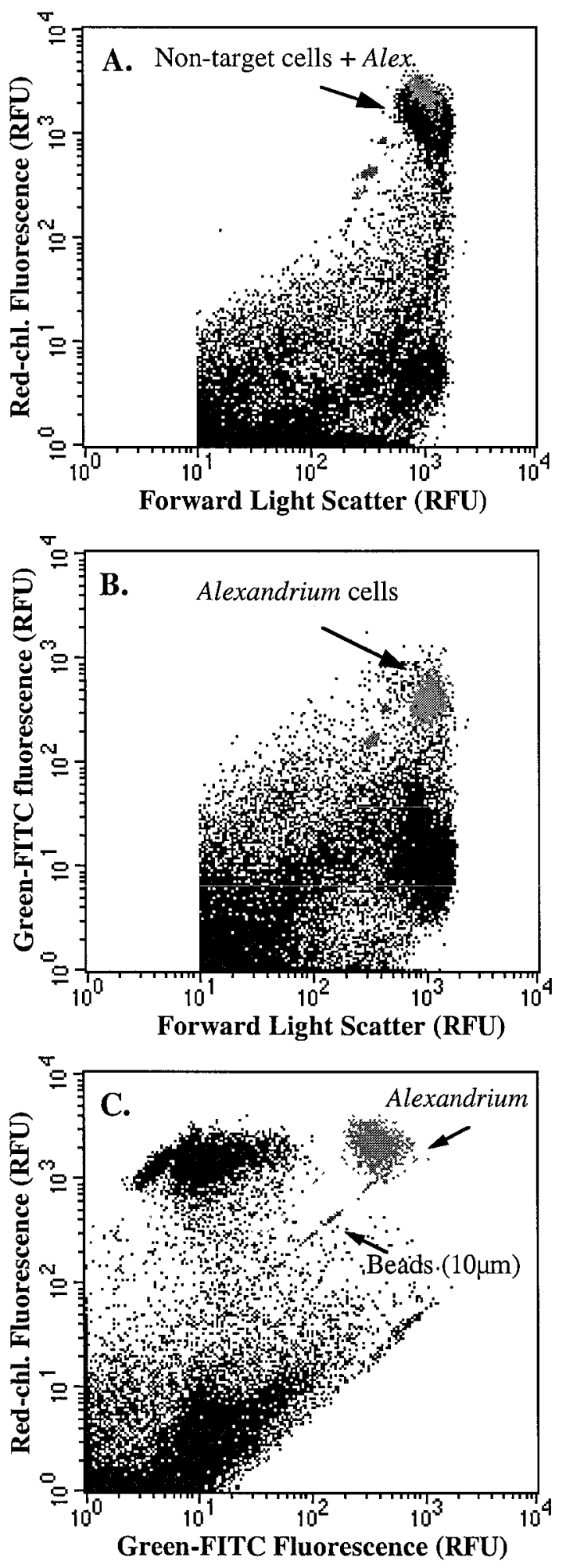
Using a positive MAb treated field sample spiked with non-target dinoflagellates and Alexandrium, the target Alexandrium population could not be separated from other, non-target dinoflagellates based only on cell size (Forward light scatter or FLS) and redchlorophyll fluorescence (Figure 2.4 A). The intensity of the red fluorescence is an indicator of the natural chlorophyll content of the cell, but other autotrophic dinoflagellates of similar size and chlorophyll content look identical to A. fundyense (Figure $2.4 \mathrm{~A}$ ). The optimal targe cell separation was achieved using the green (FITC) or orange (PE) fluorescence of the cell surface-specific MAb - fluorochrome complex in conjunction with the natural chlorophyll (red) fluorescence of the Alexandrium cells (Figure 2.4 C). Discrimination and separation of $A$. fundyense using the forward light scatter parameter and the MAb probe fluorescence was also possible (Figure 2.4 B), but the separation was not as distinct as that observed using the green-FITC fluorescence vs. the natural redchlorophyll fluorescence (Figure $2.4 \mathrm{C}$ ).

To maximize the separation of Alexandrium from a control or background cell population, a variety of fluorochrome complexes (secondary and tertiary) were tested. Two fluorochromes (FITC and PE) were used either attached to a goat anti-mouse antibody as a secondary fluorochrome, or as a tertiary molecule used in a biotin-avidin complex. The best separation was determined by comparing two different signal to noise $(\mathrm{S} / \mathrm{N})$ ratios of different values of green or orange fluorescence as determined from the flow cytometric scatter plots (Table 2.2). In Table 2.2, two S/N ratios are reported. The first $\left(\mathrm{S} / \mathrm{N}_{1}\right)$ measures the ratio of the green (or orange) fluorescence of a positive MAblabeled Alexandrium target population versus the green (or orange) fluorescence 
TABLE 2.2. Flow cytometric data comparing signal to noise ratios $(\mathrm{S} / \mathrm{N})$ from negative MMP treated and positive MAb treated field samples spiked with $A$. fundyense and other non-target dinoflagellates using different secondary and tertiary fluorochrome combinations. For each fluorochrome tested, the green (FITC) or orange (PE) fluorescence of three cell populations were examined and compared: the control cell population from a MMP-treated sample (A) and the non-target (B) and target cell populations of a MAbtreated sample (C). Two signal to noise $(\mathrm{S} / \mathrm{N})$ ratios are reported: $\mathrm{S} / \mathrm{N}_{1}=$ green or orange fluorescence of target cells $(\mathrm{C})$ versus the green or orange fluorescence of the control cells $(A)$. S $/ \mathrm{N}_{2}=$ green or orange fluorescence of target cells (C) versus the green or orange fluorescence of the non-target cells (B) (Refer to Figure 2.3 for identification and visualization of the different cell populations). The highest $\mathrm{S} / \mathrm{N}$ ratios (the greatest cell separation) were observed when FITC conjugated fluorochromes were used.

\begin{tabular}{|c|c|c|c|c|c|}
\hline \multicolumn{6}{|c|}{ Mean Relative Fluorescence } \\
\hline Fluorochrome & $\begin{array}{c}\text { A } \\
\text { Control cells } \\
\text { MMP } \\
\end{array}$ & $\begin{array}{c}\mathrm{B} \\
\text { Non-target cells } \\
\mathrm{MAb}\end{array}$ & $\begin{array}{c}\mathrm{C} \\
\text { Target cells } \\
\mathrm{MAb} \\
\end{array}$ & $\begin{array}{l}(\mathrm{C} / \mathrm{A}) \\
\mathrm{S} / \mathrm{N}_{1}\end{array}$ & $\begin{array}{l}(\mathrm{C} / \mathrm{B}) \\
\mathrm{S} / \mathrm{N}_{2}\end{array}$ \\
\hline IITC & $6.1 .(17162)^{2}$ & $11.0(6867)$ & $408.5(1813)$ & 67 & 37 \\
\hline Phycoerythrin (PE) & $5.4(10764)$ & $8.9(9550)$ & $220.4(1765)$ & 41 & 25 \\
\hline 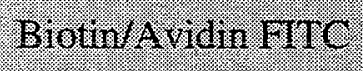 & $5.1(14866)$ & $13.3(7.52)$ & $434.8(2067)$ & 85 & 33 \\
\hline Biotin/Avidin PE & $6.8(9135)$ & $11.8(8960)$ & $312.0(2512)$ & 46 & 26 \\
\hline
\end{tabular}

${ }^{a}$ Number of flow cytometric events used to measure the mean relative fluorescence intensity

of control cell the population of a negative MMP-treated field sample spiked with nontarget dinoflagellates and Alexandrium. The second signal to noise ratio $\left(\mathrm{S} / \mathrm{N}_{2}\right)$ measures the ratio of green (or orange) fluorescence of the positive, MAb-labeled Alexandrium target population to the green (or orange) fluorescence of the non-target cell population within the same MAb-treated sample. See Figure 2.3 for visual representation of the control (A), non-target (B), and target cell (C) populations. By reporting both ratios, the effects of non-specific MAb-labeling can be assessed. For all combinations of fluorochromes used, the fluorescence of the non-target cell population in a MAb treated field 
sample was approximately double the fluorescence of a control cell population in a MMP treated field sample (Figure 2.3 and Table 2.2 - Column $A$ vs. B). Thus the $S / \mathrm{N}_{1}$ ratios were consistently higher than the $\mathrm{S} / \mathrm{N}_{2}$ ratios in all cases. When comparing fluorochromes, FITC as a secondary had the highest overall $\mathrm{S} / \mathrm{N}_{1}$ and $\mathrm{S} / \mathrm{N}_{2}$ values. From these results, we conclude that using the goat anti-mouse (GAM) FITC as a secondary fluorochrome allows the greatest separation A. fundyense in field samples. When examining the $\mathrm{S} / \mathrm{N}_{2}$ ratios the tertiary biotin/avidin signal enhancements did not increase fluorescent signal intensity as expected, and added an extra step in the sample processing, therefore, increasing the probability of cell loss.

Sample Preservation and Storage. Since the red-chlorophyll fluorescence is required for optimal A. fundyense cell separation, three different storage methods were examined to maximize the retention of red chlorophyll fluorescence: one short-term and two longterm. A. fundyense that was cultured, preserved, and stored for 2 days at $4{ }^{\circ} \mathrm{C}$ analysis was used as the short-term sample. The long-term storage samples were preserved for one year at both $4{ }^{\circ} \mathrm{C}$ and $-80^{\circ} \mathrm{C}$. Figure $2.5 \mathrm{~B}$ shows that long-term storage at $4{ }^{\circ} \mathrm{C}$ causes a significant loss in chlorophyll fluorescence for both the negative MMP treated (Figure 2.5 BI) and positive MAb treated (Figure 2.5 BII) A. fundyense when compared to the flow cytometric signatures of A. fundyense during short-term storage (Figure $2.5 \mathrm{~A}$ I \& A II). For the negative MMP treated cells that were stored at $4{ }^{\circ} \mathrm{C}$ for one year (Figure $2.5 \mathrm{~B} \mathrm{I}$ ), there also appeared to be sight increase in green fluorescence as compared to the short-term MMP treated flow cytometric signature (Figure 2.5 A I). No losses in red 
or green fluorescence were observed in samples stored for short-term $(<1$ month @ 4 ${ }^{\circ} \mathrm{C}$ ) or long-term (one year) at $-80{ }^{\circ} \mathrm{C}$ (Figure $2.5 \mathrm{~A}, \mathrm{C}$ ). Therefore, to avoid decreases chlorophyll fluorescence from preserved field samples, samples were processed within two weeks of preservation at $4{ }^{\circ} \mathrm{C}$ or were stored at $-80^{\circ} \mathrm{C}$.

Natural Field Populations. Natural field samples containing Alexandrium fundyense cells were collected, immunofluorescently stained, and stored as described previously. Flow cytometric scatter plots of the samples from Perch Pond and Casco Bay are shown in Figure 2.6. Each field location (Perch Pond and Casco Bay) depicts a series of samples that compare a negative MMP treated field sample to positive MAb treated field sample. A distinct Alexandrium population, identifiable on the basis of both green-FITC fluorescence and red-chlorophyll fluorescence was observed in both locations using a positive MAb treated field sample (Figure $2.6 \mathrm{C} \& \mathrm{~F}$ ). These Alexandrium target populations were confirmed by cell sorting and microscopic identification. With both spiked field samples and natural field samples, cell counts using the flow cytometer were 40$70 \%$ lower (data not shown) compared to immunofluorescent microscope counts prior to processing. 
Figure 2.5. Flow cytometric scatter plots of cultured Alexandrium cells stored three different ways in order to examine the effects of short vs. long-term chlorophyll preservation. For each storage method both negative MMP treated (I) and positive MAb (II) treated cell samples were compared using goat anti-mouse FITC as a secondary fluorochrome. (A) Two day (short-term) preservation at $4{ }^{\circ} \mathrm{C}$ in the dark; $\mathrm{S} / \mathrm{N}=30$. (B) One year (long-term) preservation at $4{ }^{\circ} \mathrm{C}$ in the dark; $\mathrm{S} / \mathrm{N}=6$. (C) One year preservation at $-80^{\circ} \mathrm{C}$ in the dark; $\mathrm{S} / \mathrm{N}=38$. The best preservation method appears to be either shortterm or long-term at $-80^{\circ} \mathrm{C}$. 
A. Short-term, $4^{\circ} \mathrm{C}$

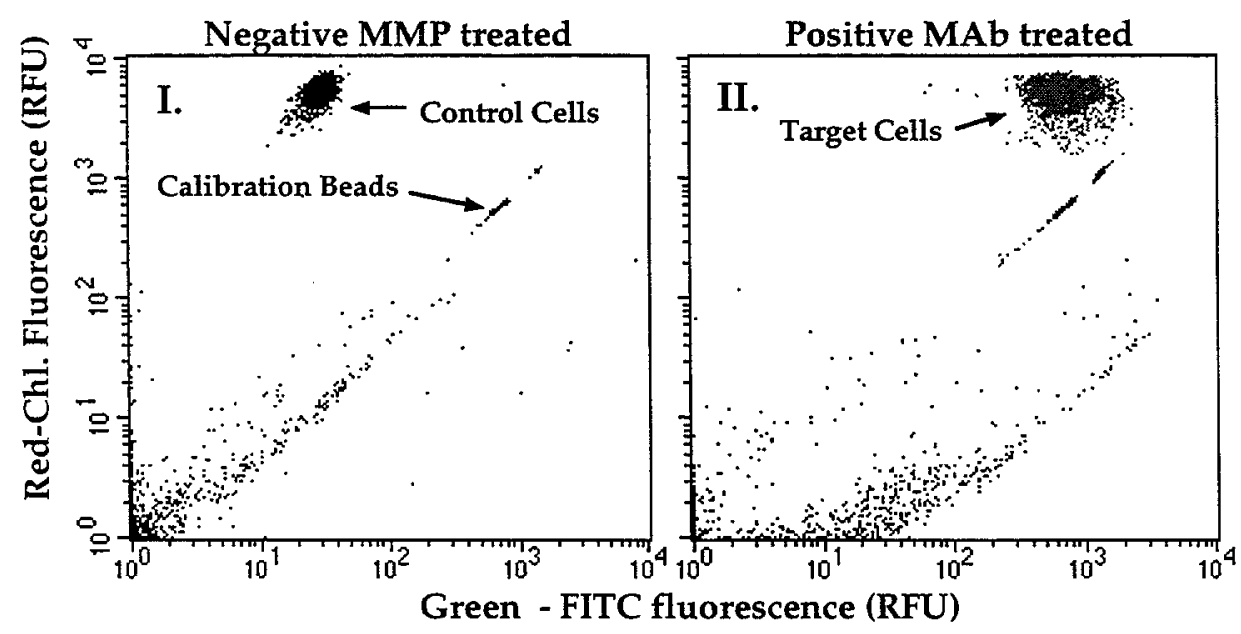

B. Long-term, $4^{\circ} \mathrm{C}$

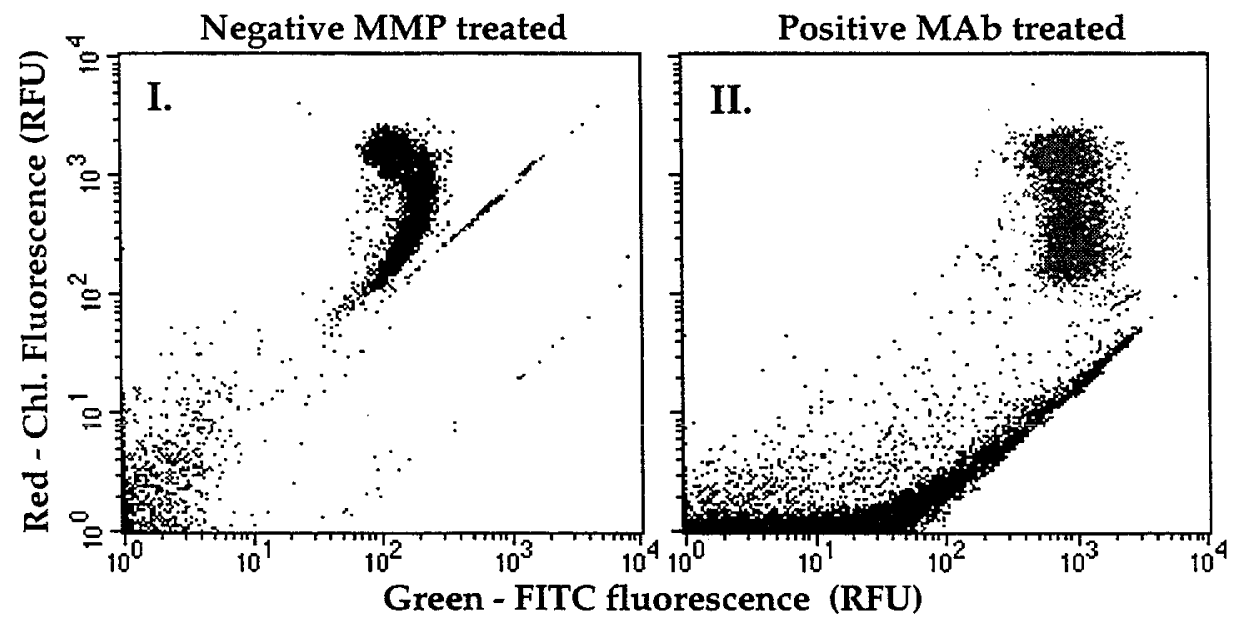

C. Long-term, $-80^{\circ} \mathrm{C}$

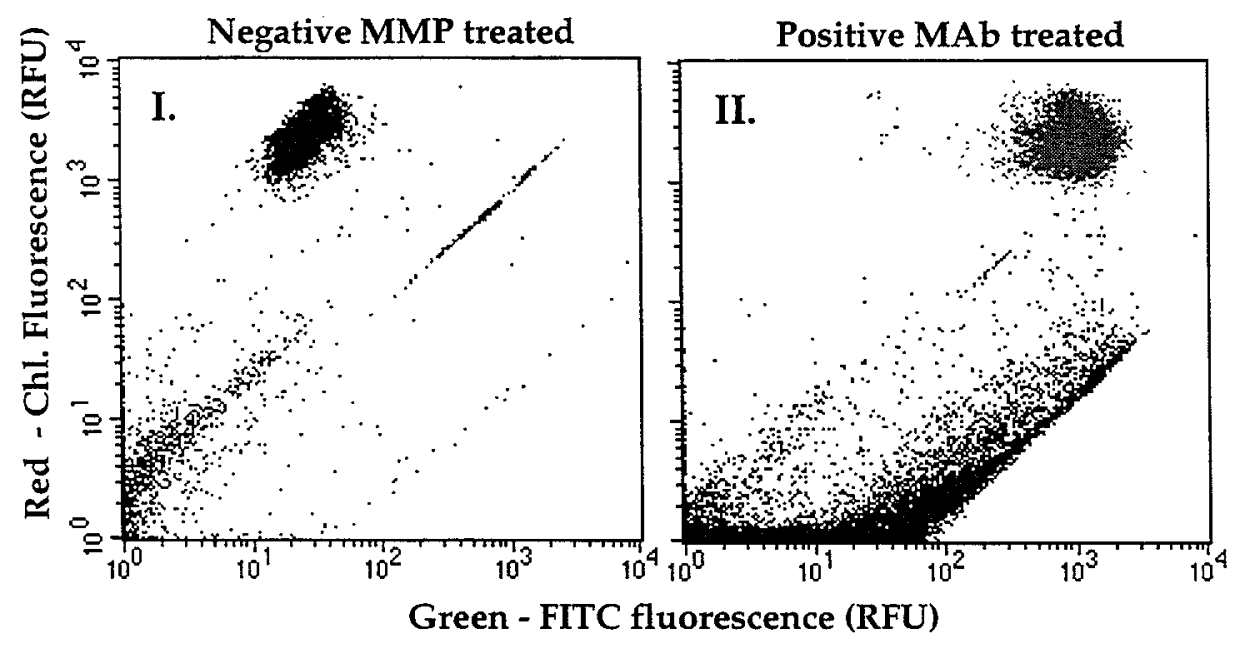


Figure 2.6. Flow cytometric scatter plots of natural field samples containing Alexandrium fundyense from Perch Pond, MA (coastal salt pond) (A-C) and Casco Bay, ME (DE) $($ black dots $=$ non target cells or unlabeled Alexandrium cells; grey dots $=$ positively labeled Alexandrium cells). For unlabeled field samples (no treatment) the inability of the natural red-chlorophyll fluorescence and cell size (FLS) to separate Alexandrium from other naturally occurring dinoflagellates is shown (A \& D). For negative MMP treated field samples (using FITC as a secondary fluorochrome), Alexandrium cells were not fluorescently labeled, therefore, only one cell population (containing Alexandrium and other cells) was detected using red vs. green-FITC fluorescence (B \& E). For positive MAb treated field samples (using FITC as a secondary fluorochrome), the fluorescently labeled (FITC) Alexandrium cell population was distinguishable from the nontarget populations using red vs. green-FITC fluorescence $(\mathbf{C} \& \mathbf{F})$. The Alexandrium cells were positively identified by cell sorting. 

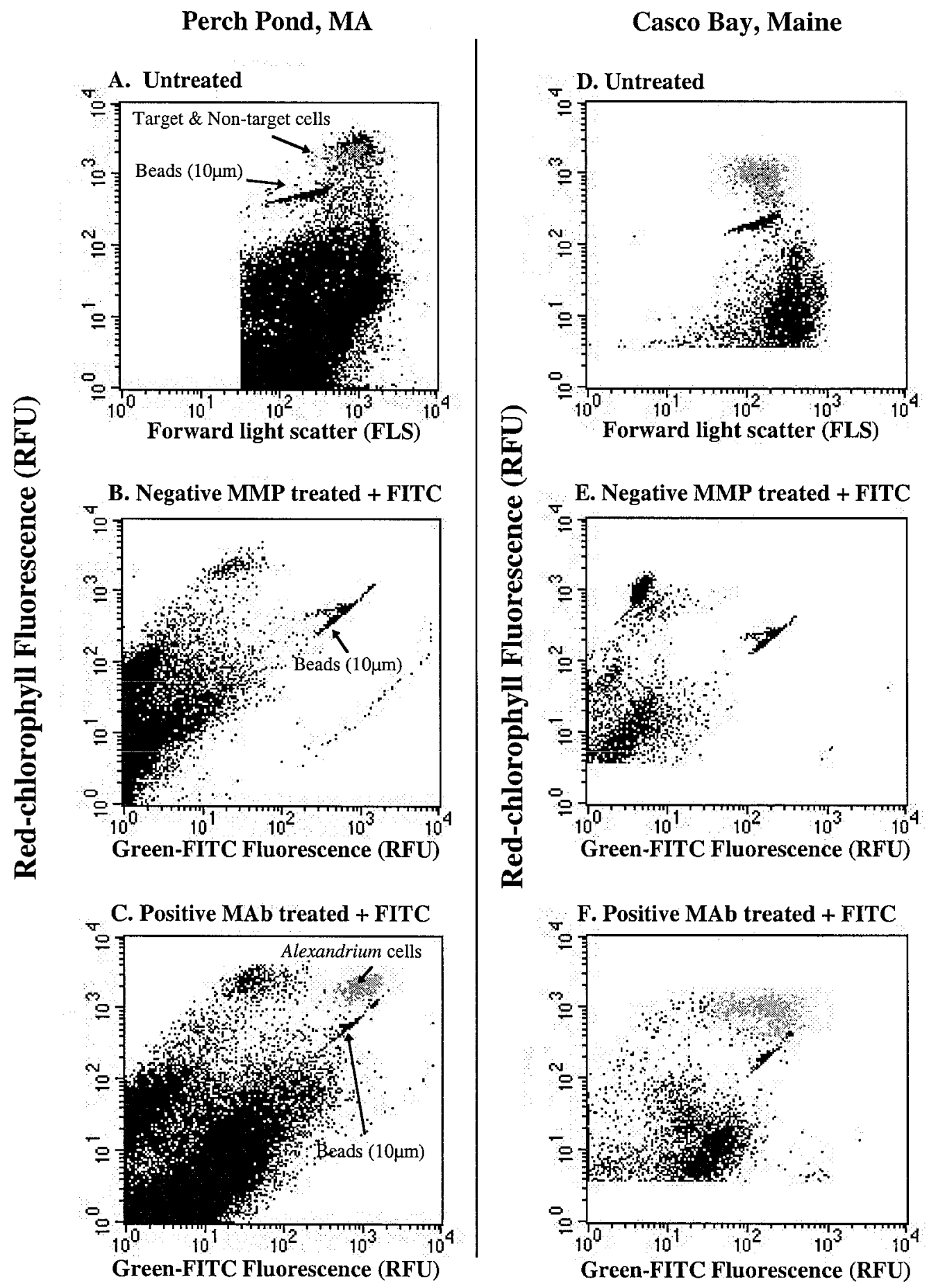


\section{Immunomagnetic Bead Separation}

For all sample bead treatments, approximately 10-30 complexed M-280 SaM beads were tightly attached to the surface of all primary MAb labeled cells, as determined by microscopic examination. Both the bead-coated target cells and the uncomplexed beads that remain in the supernatant were collected by the magnetic particle concentrator. For live and preserved cells, the indirect method of bead attachment using either M-280 streptavidin or M-280 Sheep anti-mounse (SaM) coated beads had the highest cell recoveries (Aguilera et al., 1996), therefore to minimize the number of steps we used an "indirect" approach with M-280 SaM coated beads (Figures 2.1 and 2.2). Our attempts to use the direct approach failed, since we were unable to recover more than $30 \%$ of the cells using both types of magnetic beads (M-280 streptavidin and M-280 SaM; data not shown).

Optimization of target cell recovery. The recovery percentages of live cells using different bead concentrations are presented in Figure 2.7. The highest live recovery was $87 \%$ with $3.4 \times 10^{7}$ beads, equivalent to a bead:cell ratio of approximately 300 . Bead:cell ratios ranging from 100-200 had cell recoveries ranging from 50-70\%. Ratios below 40 had very low cell recoveries - less than $30 \%$. We chose a target bead:cell ratio of 150 200 for all biochemical experiments. By using fewer beads, the number of the non-bound beads (excess beads not attached to target cells) is minimized. This reduces the control or background signal for the different biochemical measurements. 


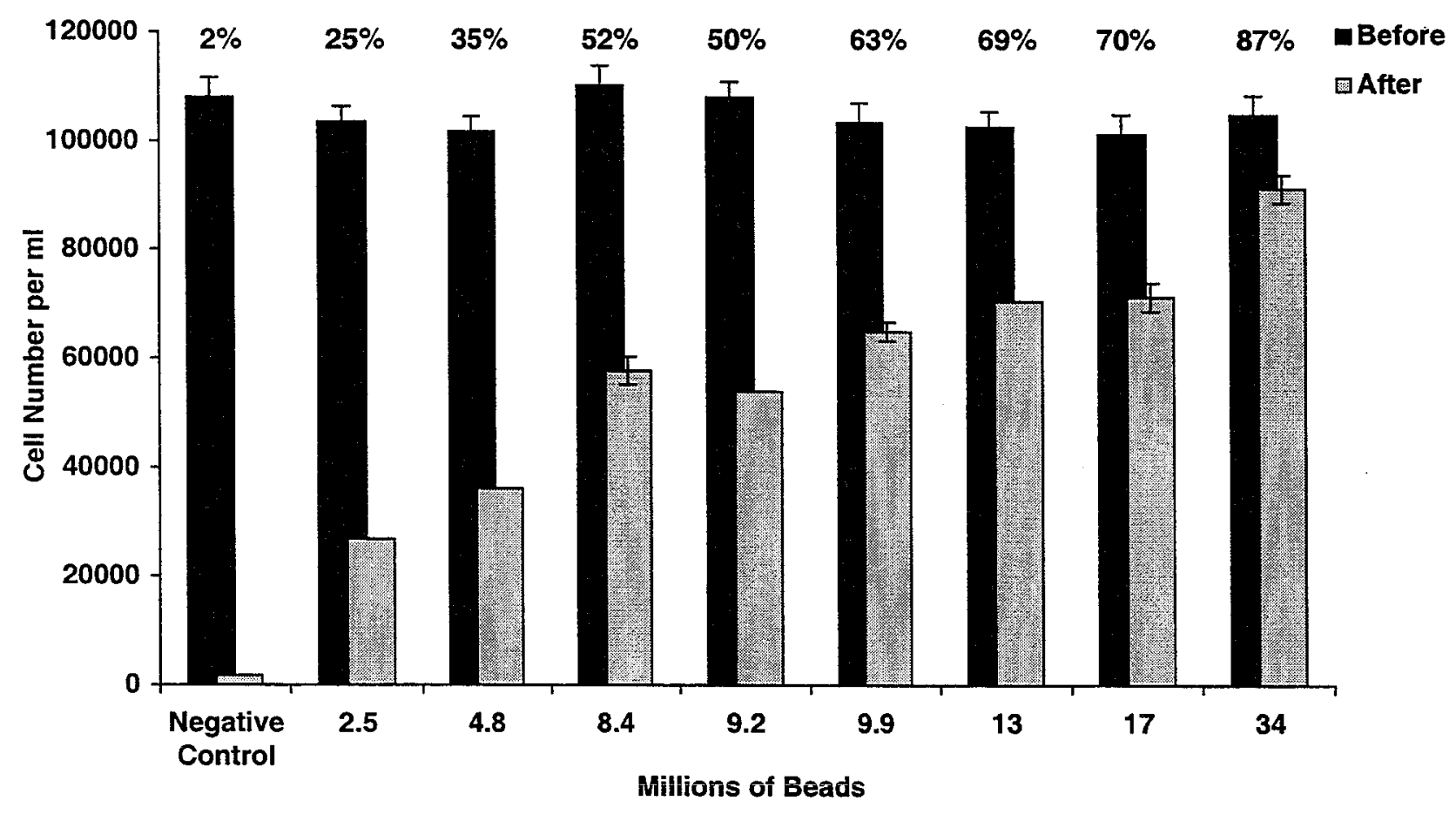

Figure 2.7. Optimization of cell recovery using the indirect immunomagnetic bead separation method with cultured Alexandrium fundyense cells. This figure shows that when comparing the cell concentration before and after magnetic bead separation the highest cell recovery or removal percentage was $87 \%$ corresponding to a bead to cell ratio of approximately 300 . Error bars represent $\pm S D, n=2$. 
The number of washes needed to effectively remove non-target cells from beadisolated Alexandrium cells was also tested. With the first two washes, $70-80 \%$ of the non-target cells were removed. The third wash typically removed an additional $10 \%$, and subsequent washes only removed an additional $1 \%$. Therefore, only 3 magnetic bead washes were used in our immunomagetic bead separation protocol in order to reduce cell loss.

Biochemical Calculations and Analysis. For the different biochemical determinations of Alexandrium after magnetic bead separation, both positive (w/MAb) and negative (without MAb) bead treatments were processed for using cultured Alexandrium cells and field samples spiked with Alexandrium cells. The negatively labeled samples represent the control or blank values for different biochemical determinations of cells after bead separation. Different negative controls were processed depending on the type of sample (cultured cells only vs. field + cultured cells). In the following sections, different biochemical results are presented in a series of tables (Tables 2.3-2.7). Within each table four negative bead and filter controls are listed in Rows A-D. In Row E-G three Alexandrium cell treatments are listed: two positive bead cell separations (with and without field sample) and a cultured cell control .

For the three Alexandrium cell treatments in each table (Rows E-G), the Alexandrium biochemical yield [BY], (e.g., chlorophyll $a$, protein, carbohydrate, carbon and nitrogen) was calculated using the appropriate negative control (as listed in Rows A-D in Tables 2.3-2.7) as follows: 
1. Cultured cell Control - (Alexandrium fundyense prior to bead separation - Row E).

$$
[T]-[F]=[B Y]
$$

where $[T]$ is the total biochemical yield of the cultured cells + filter, $[F]$ is the biochemical yield of the Filter Control w/ PBS (negative control) as listed in Row A within each Table, and $[B Y]$ is the biochemical yield of the Alexandrium cells as listed in Row E.

2. Positive cultured cell bead separation - Row F in Tables 2.3-2.7

$$
[T]-[B C]=[B Y]
$$

where $[T]$ is the total biochemical yield of positively labeled cultured cells after bead separation + excess beads and filter, $[B C]$ is the biochemical yield of the negative bead control or bead control + Alexandrium cells as listed in Row B or C within each Table, and $[B Y]$ is the biochemical yield of the Alexandrium cells as listed in Row F.

3. Field + Cultured cell bead separation - Row G in Tables 2.3-2.7

$$
[T]-[F C]=[B Y]
$$

where $[T]$ is the total biochemical yield of positively MAb-labeled cultured cells from an Alexandrium spiked field sample after bead separation + excess beads and filter, $[F C]$ is the biochemical yield of negative field control + beads \& Alexandrium cells as listed in Row D within each Table, and $[B Y]$ is the biochemical yield of the Alexandrium cells as listed in Row G.

Chlorophyll $a$. The total chl $a$ per cell in untreated cultured A. fundyense (without bead treatment) was $58.5 \pm 1.8 \mathrm{pg} \mathrm{cell}^{-1}( \pm \mathrm{SD}, \mathrm{n}=3$; Table 2.3 - Row E). After bead separation using live cultured Alexandrium cells only (Table 2.3 Row F) or field samples spiked 


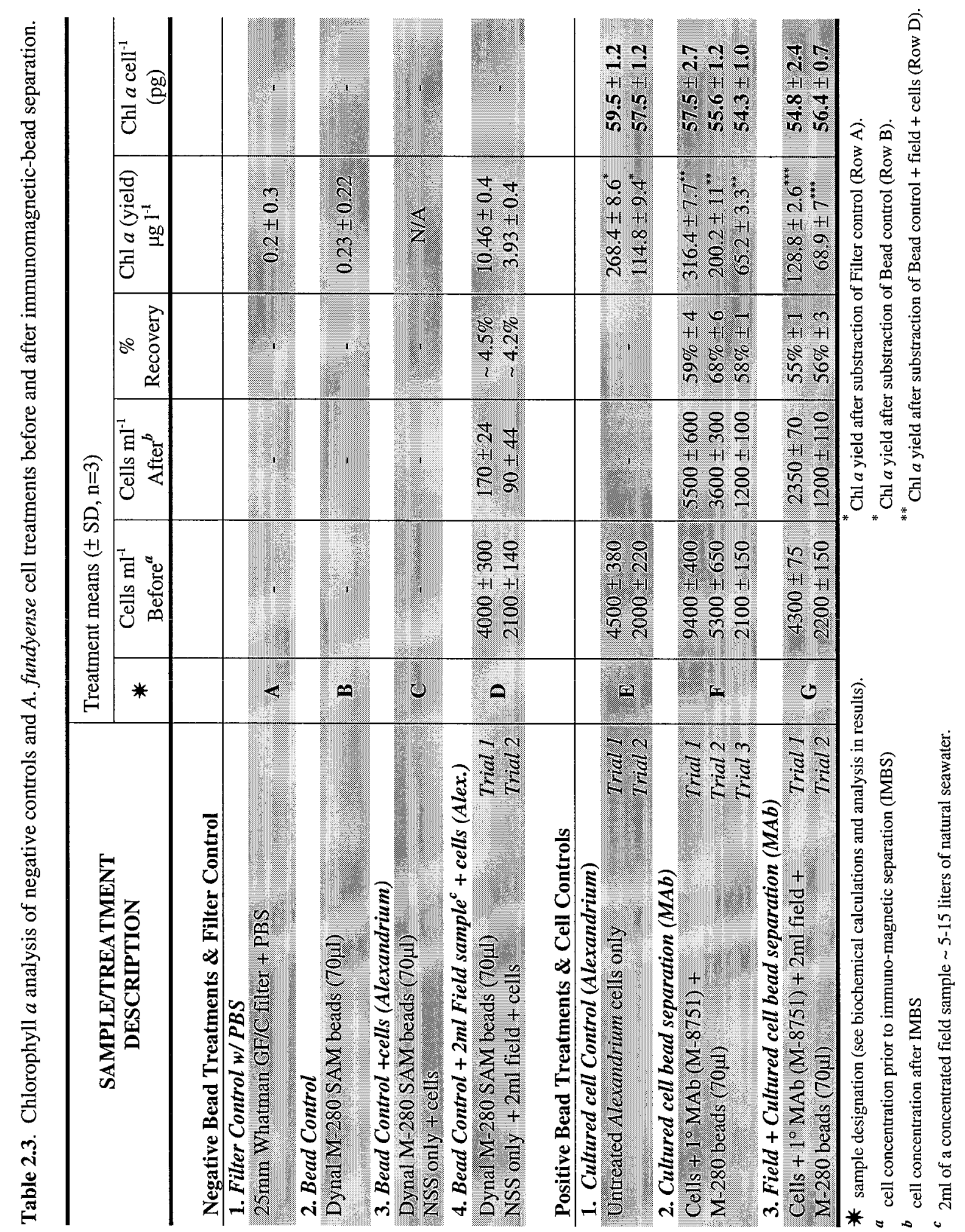


with live $A$. fundyense cells (Table 2.3 Row $\mathrm{G}$ ) the chl $a$ concentration was not significantly different $(\mathrm{p}<0.05)$ when compared to the untreated cultured controls. The percent cell recovery for the different bead treatments was between $55-68 \%$, as expected for the bead:cell ratio of 200 used during these experiments. Clearly, non-target or residual background field cells do not contribute significantly to the overall chl $a$ signal when $A$. fundyense cell are isolated from field samples using magnetic beads.

Carbohydrate. The total carbohydrate per cell for the untreated, cultured Alexandrium cells (without bead treatment) was between $490-530$ pg cell $^{-1}$ (Table 2.4 Row E). After bead separation using live cultured Alexandrium cells only (Table 2.4 Row F) the carbohydrate concentration was not significantly different $(p<0.05)$ when compared to the untreated cultured controls. However, after cell separation from field samples spiked with Alexandrium (Table 2.4 Row G) the carbohydrate concentration per cell was significantly different ( $>0.05$ ) from the control cells. Separation of the target Alexandrium cells was again successful, with recovery percentages as high as $75 \%$.

Protein. For these experiments, both nitrogen replete (N-replete) and nitrogen starved (N-starved) A. fundyense cells were used to determine if physiological differences can be detected using the bead separation method. The untreated filter control with PBS yielded an average $0.4 \mu \mathrm{g}$ protein filter ${ }^{-1}$ (Table 2.5 Row A). The negative bead control yielded $2.1 \mu \mathrm{g}$ protein $\mathrm{ml}^{-1}$ (Table 2.5 Row B), whereas the negative bead control + A. fundyense cells and field sample yielded 4.5 and $4.9 \mu \mathrm{g}$ protein $\mathrm{ml}^{-1}$ for nitrogen replete and nitro- 


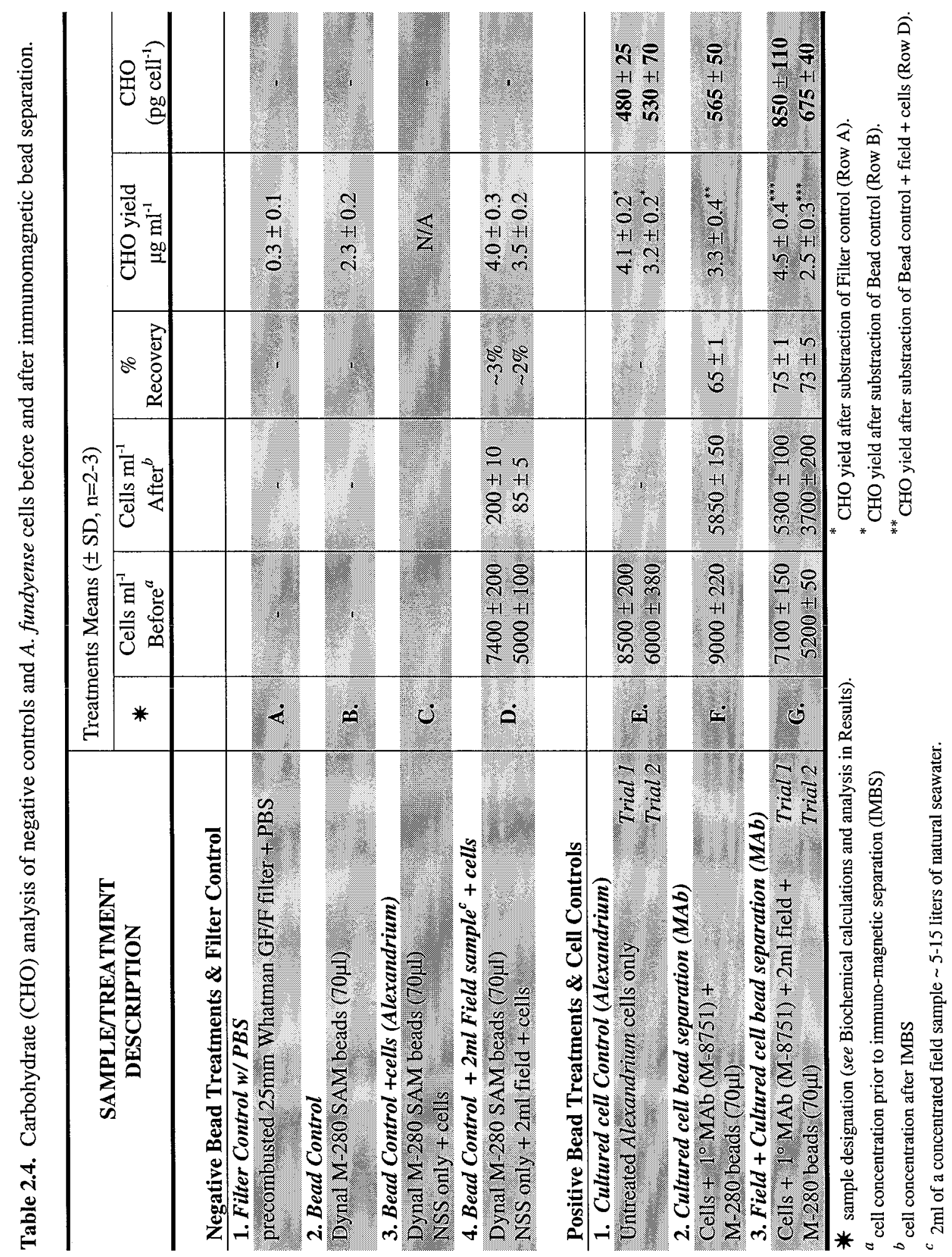




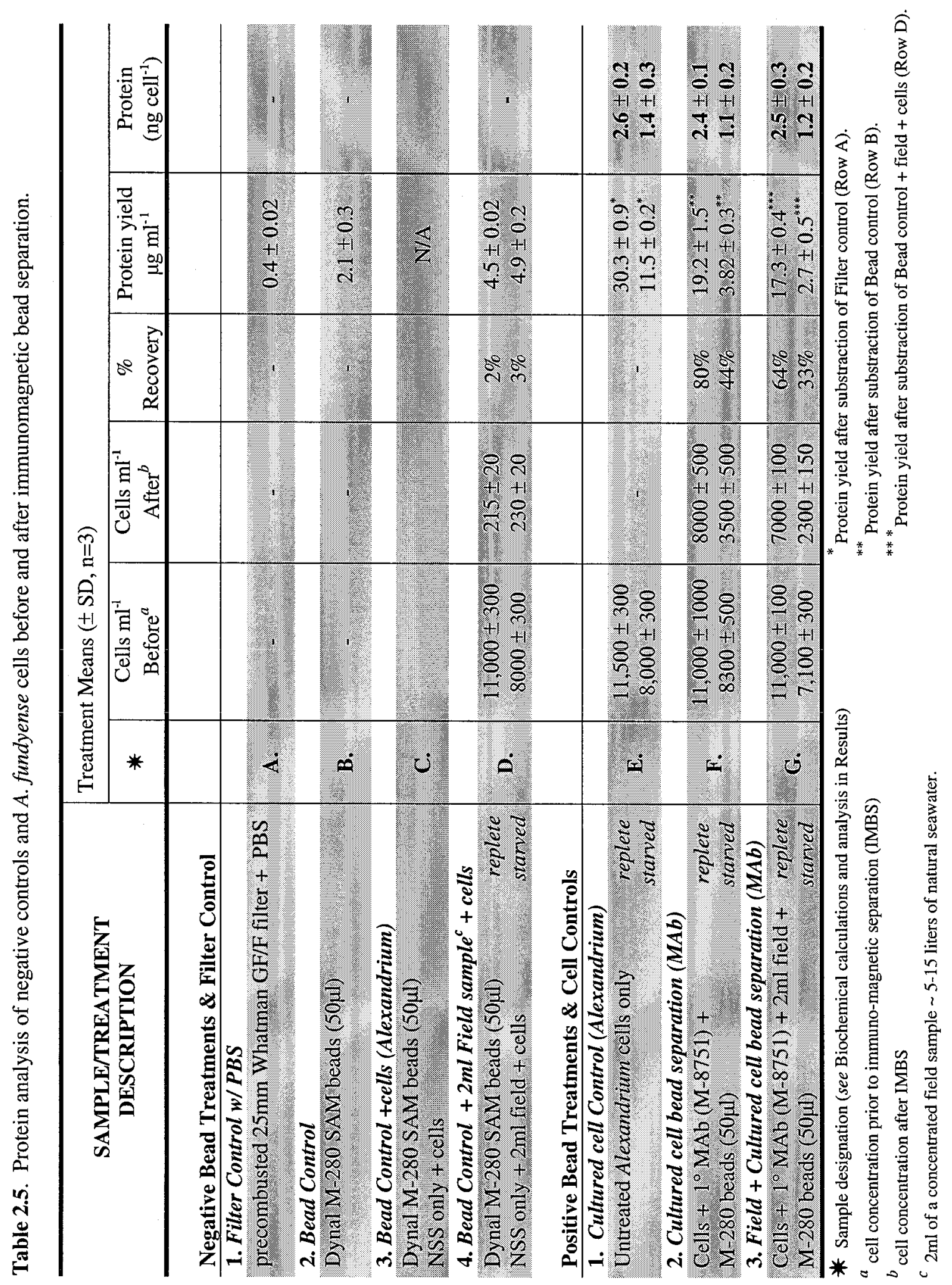


gen-starved cells respectively (Table 2.5 Row C). The values for these bead controls are similar, as expected, since the target cells $A$. fundyense were not isolated due to the absence of the primary monoclonal antibody (MAb). The total mean protein concentration was $2.5 \pm 0.2$ and $1.4 \pm 0.3 \mathrm{ng} \mathrm{cell}^{-1}$ respectively for $\mathrm{N}$-replete control and $\mathrm{N}$-starved untreated cultured cells without bead treatment (Table 2.5 Row E.). Protein concentrations obtained for both N-replete and N-starved separated $A$. fundyense from positive bead treatments (with and without field sample) were not significantly different from the untreated cultured controls ( $p<0.05$ ), (Table 2.5 Row F \& G). Cell recovery percentages were between 50-70 percent, as expected for a bead:cell ratio of ca. 200 .

Carbon and Nitrogen elemental composition. Pre-combusted filters with PBS yielded, on average, $6.8 \mu \mathrm{mol} \mathrm{C}$ and $0.2 \mu \mathrm{mol} \mathrm{N}$ per filter (Table 2.6 Row A). Other experimental negative controls were also processed that did not use the primary MAb for cell labeling. The Dynal M-280 negative bead control contained $20.9 \mu \mathrm{mol} C$ and $1.5 \mu \mathrm{mol} \mathrm{N}$ per $50 \mu \mathrm{l}$ bead suspension, equivalent to a molar C:N ratio of 13.6 (Table 2.6 Row B). Similar to the protein determinations both nitrogen replete (N-replete) and nitrogen starved $(\mathrm{N}$ starved) A. fundyense cells were used for cell separation. The other negative bead controls for $\mathrm{C}$ and $\mathrm{N}$ yielded very similar results since $A$. fundyense was not positively labeled and therefore not separated (Table 2.6 Rows C \& D). For the precombusted filter + PBS and all negative bead controls (Table 2.6 Rows A-D) the $\mathrm{C}$ and $\mathrm{N}$ values were compared to the instrument blank or zero reading. 


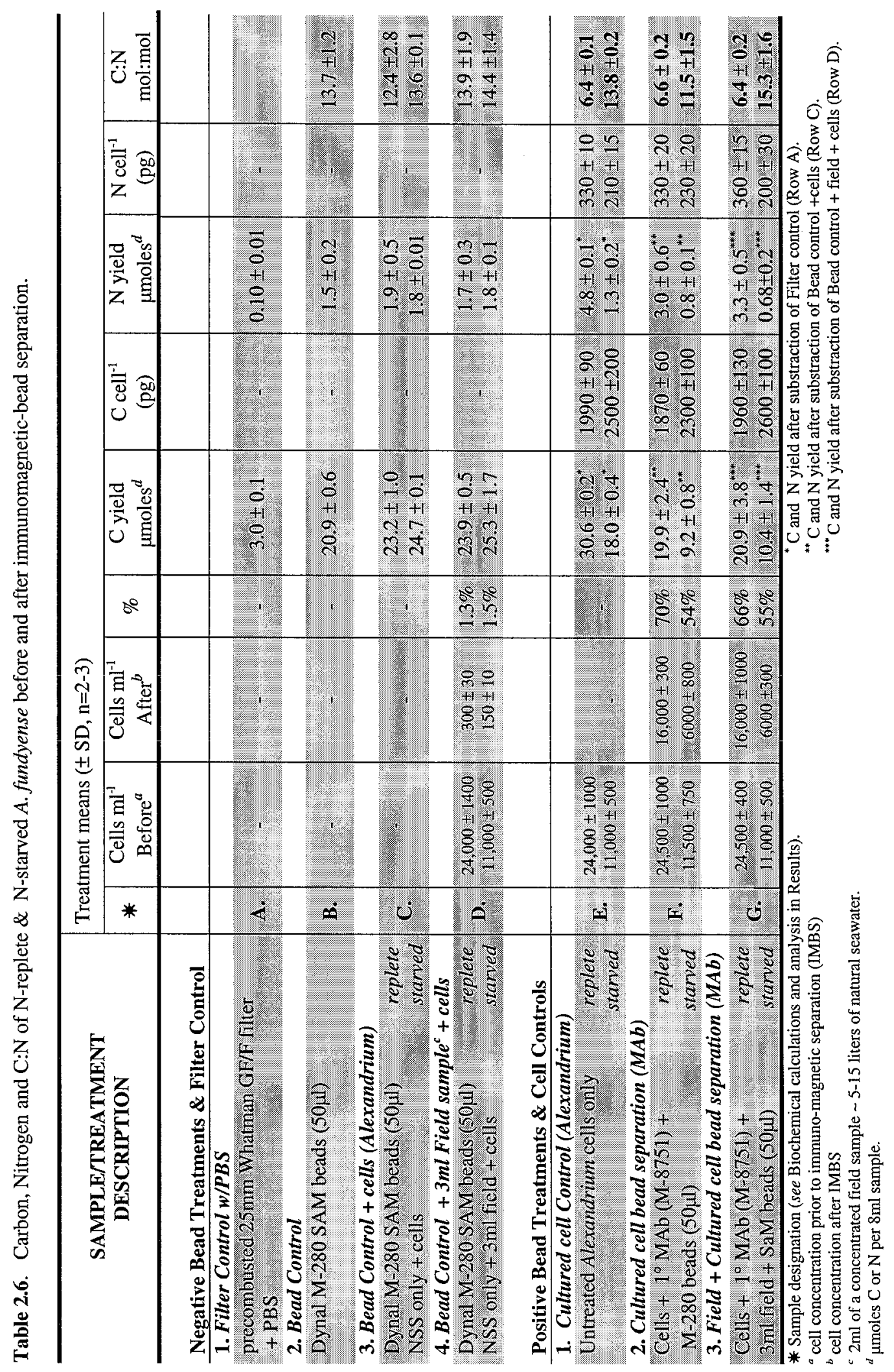




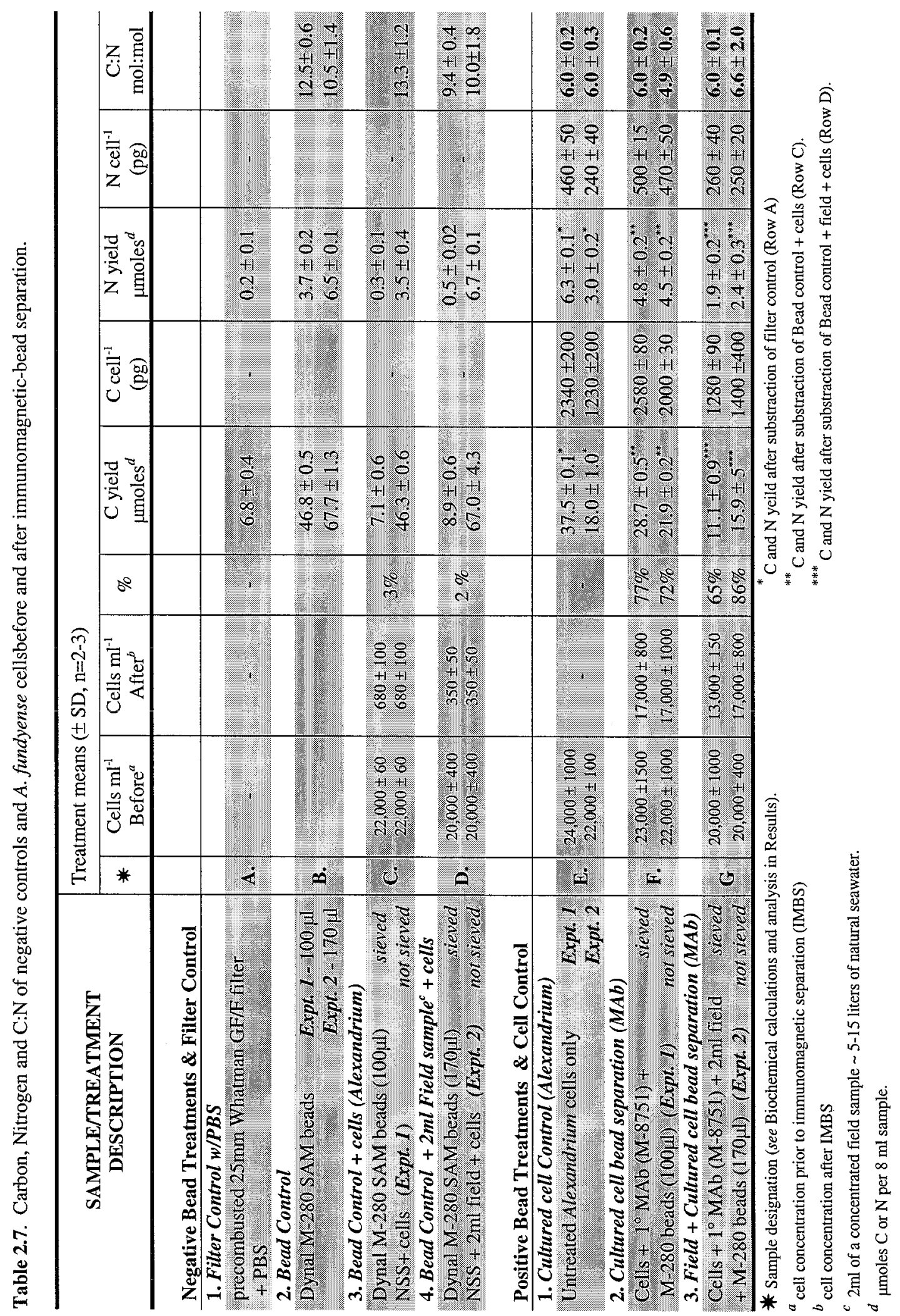


The A. fundyense untreated cell controls yielded an average $1990 \pm 90$ and $2500 \pm$ $200 \mathrm{pg} \mathrm{C}$ cell $^{-1}$ and $330 \pm 10$ and $210 \pm 15 \mathrm{pg} \mathrm{N}$ cell $^{-1}$ for $\mathrm{N}$-replete and $\mathrm{N}$-starved cells respectively (Table 2.6 Row E). C:N ratios (mol:mol) averaged $6.4 \pm 0.1$ for $\mathrm{N}$-replete cells and $13.8 \pm 0.2$ for $\mathrm{N}$-starved cells as calculated from the $\mu$ mole $\mathrm{C}$ and $\mathrm{N}$ per filter listed in Table 2.6, Row E. Carbon and $\mathrm{N}$ concentrations per cell (pg) obtained for both N-replete and N-starved $A$. fundyense after positive bead cell separation (with and without field sample) were not significantly different from the untreated cultured cell controls $(p<0.05)$, (Table 2.6 Row $F \& G)$. The C:N ratio for the bead treated $N$-replete cells was not significantly different from the N-replete Alexandrium untreated controls, however the C:N ratio for the $\mathrm{N}$-starved cells was significantly different ( $p>0.05$ ) from the $\mathrm{N}$ starved untreated cell controls.

In Table 2.6, negative bead controls were subtracted from the positive cell treatments prior to calculating $\mathrm{C}$ and $\mathrm{N}$ per cell values and $\mathrm{C}: \mathrm{N}$ ratios (see Biochemical Calulations and Analysis in Results). As observed from the $\mathrm{C}$ and $\mathrm{N}$ values of the negative bead controls, the beads comprise approximately $50-60 \%$ of the total $\mathrm{C}$ and $\mathrm{N}$ of a of positive bead treated sample (with or without field sample) after bead separation. Therefore, there is a high potential for error in the calculated residuals. In an attempt to remove this discrepancy, two additional experiments were performed. The first experiment (Expt. 1 - Table 2.7) used cultured Alexandrium cells and tested the removal of excess (unbound) beads from the positive cell treatments after bead separation but before analysis of particulate $\mathrm{C}$ and $\mathrm{N}$. The second experiment (Expt. 2) was similar to the first except Alexandrium spiked field samples were utilized for the positive bead treatments. 
Excess beads were removed by sieving the cell/bead suspension after magnetic separation through a $20 \mu \mathrm{m}$ Nitex sieve. Cell/bead complexes are large $(\sim 30-40 \mu \mathrm{m})$ and are retained on the sieve, whereas the excess $2.8 \mu \mathrm{m}$ unbound beads pass through the Nitex sieve. Afterwards, the cells (bead-cell complexes) were back-washed off the sieve and then filtered for determination of particulate $\mathrm{C}$ and $\mathrm{N}$. For both of these experiments listed in Table 2.7 only N-replete Alexandrium cells were used. The untreated cell controls for Expt. 1 and 2 yielded an average $2340 \pm 200 \mathrm{pg}$ and $1230 \pm 200 \mathrm{pg} \mathrm{C}$ cell $^{-1}$ and $460 \pm 50$ pg and $240 \pm 40 \mathrm{pg} \mathrm{N}$ cell $^{-1}$, respectively with an average C:N ratio of $6.0 \pm 0.2$ (Table 2.7 Row E). Two bead volumes were used for cell separation, 100 and $170 \mu \mathrm{l}$, that when filtered contained $47 \mu \mathrm{mol}$ and $68 \mu \mathrm{mol} \mathrm{C}$ and $3.7 \mu \mathrm{mol}$ and $6.5 \mu \mathrm{mol} \mathrm{N}$, respectively (Table 2,7 Row B). For a $100 \mu \mathrm{l}$ bead suspension, the $\mathrm{C}$ and $\mathrm{N}$ values for the negative bead control + cells dropped from 46.3 to $7 \mu \mathrm{mol} \mathrm{C}$ and 3.5 to $0.3 \mu$ moles $\mathrm{N}$ after sieving (Table 2.7 Row C) - nearly a 7-fold reduction in C and 10-fold reduction in N. Similarly, the $\mathrm{C}$ and $\mathrm{N}$ values of the negative bead control + field sample and Alexandrium cells (Table 2.7 Row D), decreased by nearly an order of magnitude after sieving. For all negative bead control listed in Table 2.7 the values were compared to the instrument blank or zero reading.

Carbon cell ${ }^{-1}, \mathrm{~N}$ cell ${ }^{-1}$, and $\mathrm{C}: \mathrm{N}$ ratios (mol:mol) obtained during both Expt. 1 and 2, after positive bead treatment (Table 2.7 Row $F$ \& G) with excess bead removal were not significantly different $(\mathrm{p}<0.05)$ from the corresponding untreated cultured cell controls in Table 2.7 Row E. However, without sieving prior to $\mathrm{C}$ and $\mathrm{N}$ analysis the $\mathrm{C}$ cell ${ }^{-1}$, $\mathrm{N}$ cell ${ }^{-1}$, and C:N were too variable in some cases (high SD) such that statistical tests 
could not be performed. Over all, it is recommended that for $\mathrm{C}$ and $\mathrm{N}$ determinations of positive bead treatments that excess bead are removed prior to $\mathrm{CHN}$ analysis. For all $\mathrm{C}$ and $\mathrm{N}$ determinations cell recovery percentages were between $65-86$ percent, as expected for a bead:cell ratio of ca. 200-300. 


\section{DISCUSSION}

A major constraint to autecological studies of phytoplankton is the lack of methods for species-specific physiological measurements in natural waters. The need for such information is especially apparent in studies of harmful algal blooms, where a single species can be responsible for significant human health and ecosystem damage. The development of species-specific, cell surface antibodies (e.g., Campbell, 1987; Shapiro, 1989; Anderson, 1995) makes it possible, in principle, to undertake these types of measurements. If cells are labeled with antibodies, they can then be rendered fluorescent and detected by eye or with instruments such as flow cytometers. They can also be counted and even separated using cell sorting features on such instruments. The antibodies can also be linked to magnetic beads that can be used to separate the cells from co-occurring organisms (Aguilera et al., 1996), however, this method needs to be adapted for larger volume field samples and the separation of live cells for biochemical analysis.

The potential for major advances in phytoplankton autecology is thus significant, but to date, much of the work with species-specific, cell surface antibodies has been developmental and laboratory-based, with only limited efforts to apply the methods to field populations (e.g. Vrieling et al. 1994 and Vrieling et al. 1995). In this study we provide an evaluation of two antibody-based approaches to the isolation, enumeration, separation and biochemical analysis of a target species - the toxic dinoflagellate Alexandrium fundyense - in natural plankton samples. One approach used flow cytometry in conjunction with cell surface antibodies linked to fluorescent molecules. The second uses anti- 
bodies linked to magnetic beads as a means to separate our target species from mixed plankton samples for subsequent biochemical analysis. In both cases, valuable data can be collected on the target species, but some measurements are not possible, and others have limitations that must be recognized. These applications are discussed in more detail below.

\section{Immunofluorescence and Flow Cytometry}

Discrimination and Signal Enhancement. Flow cytometry has long been used to discriminate among planktonic organisms that differ with respect to size and optical characteristics such as fluorescence or light scatter. For example, Synechococcus spp. and prochlorophytes both have a unique size and pigment composition that allow them to be distinguished from co-occurring organisms using such instruments (Chisholm et al. 1988; Olson et al. 1988). Other phytoplankton that are less optically distinct (and less numerous) are not easily resolved, however. The advent of species-specific antibody and oligonucleotide probes that label target species with fluorescent "tags" would seem to provide a solution to this problem - namely the facile discrimination of a species of interest due to the fluorescence of the attached fluorochrome. In practice, immunofluorescence has been used successfully for whole-cell, microscopic identification and enumeration (e.g., Shapiro et al., 1989; Anderson 1995), based on the human eye's ability to detect subtle differences in fluorescent color and intensity as well as cell size and morphology. It also has been used in an automated fashion with flow cytometry, but generally only on 
laboratory cultures, such as with Alexandrium sp. (Costas and Lopez-Rodas 1996; Sako et al. 1996), Gyrodinium aureolum and Gymnodinum sp. (Vrieling et al. 1994; Vrieling et al. 1995; Vrieling and Anderson 1996; Vrieling et al. 1996; Vrieling et al. 1997), and other potential $\mathrm{HAB}$ species. When flow cytometry and antibody probes are used with field populations, however, problems arise because the immunofluorescent tags are not sufficiently bright for the unequivocal identification of a species within a mixed plankton assemblage. This may reflect variability in the labeling intensity of the antibody on the target cell, perhaps due to cells in differing physiological states (Anderson et al., 1999), or might simply result from the natural autofluorescence of other planktonic organisms, which overlaps with the wavelength of the probe fluorochrome. Furthermore, even small levels of cross-reactivity between the probe and non-target organisms results in a continuum of fluorescence labeling that can overlap with that of a target population (Figure 2.3).

In order to enhance the signal strength of the labeled target cells relative to background fluorescence, biotin-avidin fluorochrome combinations are sometimes used, since this theoretically results in more fluorescent molecules per binding site. Previous work by Vrieling et al. (1993), demonstrated how a biotinylated secondary antibody that reacts with a FITC conjugated streptavidin molecule significantly increased the S/N ratio (signal enhancement) with Gyrodinium aureolum. However, in our study, increasing the signal intensity of the Alexandrium cells using biotin-avidin labeled fluorochromes also increased the background fluorescence, most likely due to some non-specific binding of the primary MAb to other cells and detritus (Table 2.1). The biotin-avidin fluorochrome 
combination did enhance signal intensity compared to control $A$. fundyense cells with no primary antibody $\left(\mathrm{S} / \mathrm{N}_{1}\right)$ but when used with natural field populations where non-specific binding will occur, $\mathrm{S} / \mathrm{N}_{2}$ did not change $\left(\mathrm{N}_{2}\right.$ is the fluorescence of the non-target field cells within the primary MAb labeled sample - see Figure 2.3). In effect, there was no significant difference in the $\mathrm{S} / \mathrm{N}$ ratio between a secondary fluorochrome such as FITC and a biotin-avidin fluorochrome under field conditions (Table 2.1). Since more steps are involved in the labeling process with biotin-avidin with no significant signal enhancement, it is not worth the extra effort to use this labeling approach, at least for $A$. fundyense and the MAb used in this study.

It is also possible to enhance signal strength using a different fluorochrome, phycoerythrin (PE). Here again we found that this theoretical enhancement was not evident in practice - that FITC fluorochrome combinations yielded higher signal to noise ratios. PE was useful but was not as bright, therfore, the target species (Alexandrium) could not be identified and sorted on the basis of antibody labeling alone. For Alexandrium, discrimination and separation were only possible if other optical characters of the dinoflagellate were used in conjunction with the probe fluorescence. The most useful additional parameter was chlorophyll red fluorescence, but forward light scatter (a proxy for cell size) was also useful. By utilizing the appropriate probe fluorescence, chlorophyll fluorescence, and/or size, it was possible to identify the target population (Figure 2.6). These results are similar to those reported by Vrieling (1996) who used antibody probes and chlorophyll autofluorescence to discriminate Gyrodinium aureoleum populations in natural waters using flow cytometry. Other studies, (e.g., Sako et al, 1996) have also found 
that probe fluorescence intensity is not sufficient by itself for discrimination of a target population using flow cytometry, but many of these problems could be due to other factors, such as, the use of an inappropriate blocking agent.

Cell Preservation. Given the importance of chlorophyll autofluorescence as a diagnostic character, it was imperative that cells be preserved in such a way that this signal was preserved as much as possible (Figure 2.5). I do not address the issue of different fixatives, as this has been discussed in greater detail in previous studies and a generally accepted fixative routinely used in immunological studies is formaldehyde or "paraformaldehyde" (Peperzak et al. 2000). In this study and in previous immunofluorescent studies in our laboratory, a 5\% final concentration buffered formalin was shown to produce good antigen binding capacity. This allowed storage at $4{ }^{\circ} \mathrm{C}$ for short periods (up to one month data not shown) without appreciable loss of the chlorophyll autofluorescence needed as a diagnostic character for effective separation of $A$. fundyense from field samples. However, for long-term storage ( $>1$ month) it is recommended that the samples be maintained at $-80^{\circ} \mathrm{C}$ until processing for flow cytometry.

Cell Enumeration. For a flow cytometer to be useful in studies of natural plankton populations, one needs to identify a target species and then enumerate and/or separate it from co-occurring organisms. Our studies demonstrated that the use of chlorophyll fluorescence in conjunction with an antibody probe allows a population to be identified and sorted, but accurate enumeration was not achieved. As reported by Vrieling et al. (1995) 
for Gyrodinium aureolum, we encountered significant cell loss during processing of samples for flow cytometric analysis. We determined that there are direct cell losses associated with the incubations and wash steps, but also found that inaccurate cell counts occurred because larger cells (e.g., A. fundyense) would partially block the flow cytometer sample tubing. As the cells accumulated in the tubing, vortexing the sample while the flow cytometer was collecting data would temporarily dislodge the cells within tubing and a "normal" flow rate would resume. Nonetheless, the flow rate of large cells through the tubing continually changed through time while smaller particles, such as the $10 \mu \mathrm{m}$ calibration beads, passed through the flow cell and were enumerated more frequently. Since calibration beads or sample weights are then used to calculate cell numbers, our flow cytometric counts of $A$. fundyense were consistently lower than those determined microscopically. Flow cytometric tubing made from different plastics (e.g., silicone tubing) and with different internal diameters (maximum $100 \mu \mathrm{m}$ ) were tested but did not eliminate the counting errors (data not shown). Perhaps the solution lies with newer flow cytometers designed expressly for phytoplankton, such as the European Optical Plankton Analyser (EurOPA) (Peeters et al. 1989; Jonker et al. 1995; Peperzak et al. 2000) that have much larger tubing and flow cells. Even without such instruments, it may still be useful to have semi-quantitative flow cytometry results that provide rough estimates of the concentrations (or even the presence or absence) of a target species in field samples. This approach is used by the Dutch monitoring program for early detection of Gyrodinium aureolum in coastal waters (Vrieling et al. 1995). 
Cell Separation. Once a target population has been identified on the flow cytometer, it is possible to sort cells using the gating characteristics as designated by the flow cytometer. The sorted cells can then be used to verify the identification, but in theory, can also be used for certain types of biochemical analysis. In practice, however, we found that for dinoflagellates such as Alexandrium, the time required for cell sorting became prohibitive given the relatively large numbers of cells required for biochemical analyses and the slow pace of cell sorting. For example, working with concentrated plankton samples containing $A$. fundyense cells, 20 minutes of sorting time were required to obtain $\sim 2000$ cells. Clearly, this separation rate is dependent on the initial cell abundance in the field and the extent of concentration. For those who do not have frequent and continual access to a sorting flow cytometer, this approach to species separation and analysis is simply not feasible.

\section{Immunomagnetic Bead Separation}

Cell Separation. An alternative approach to separating target cells from a plankton sample utilizes the same antibody probes, but coupled to magnetic beads rather than to fluorochromes. Currently, immunomagnetic beads are used extensively in the biomedical field for separating a variety of cell types, isolating proteins and separating RNA \& DNA. Only recently has this method been applied to environmental samples, such as contaminated food or fecal matter (Tomoyasu 1992, Wright et al. 1994, Tomoyasu 1998). Aguilera et al. (1996) used this method to separate Alexandrium spp. from preserved field sam- 
ples, and have recently shown that some biochemical parameters can be measured using separated cells from both live and preserved cultures (Aguilera et al. in press). The magnetic separation method used by these authors to isolate Alexandrium sp. uses very small volumes (less than $1 \mathrm{ml}$ ). Alexandrium spp. concentrations are typically very low in the coastal waters of the Gulf of Maine (undetectable-10,000 cells liter ${ }^{-1}$; unpublished data), so field samples need to be concentrated before an appropriate number of cells can be isolated for biochemical analysis (unpubl. res.). Here we describe a modified immunomagnetic separation method using larger volumes that makes it possible to separate and biochemically characterize field populations of $A$. fundyense.

Aguilera et al. (1996) examined many protocols for cell separation by varying the mode of bead attachment (direct vs. indirect), the type of magnetic bead, and many other small modifications to maximize target cell recovery and minimize non-target cell binding. As in Aguilera et al (1996), an indirect bead attachment approach was chosen here, in combination with secondary SaM paramagnetic beads. Initial efforts were focused on maximizing the recovery of cultured Alexandrium cells using larger volumes, such as, determining the optimal bead:cell ratio, length of incubations and optimal number of washing steps. The optimal bead to cell ratio was ca. 200-250. Although larger bead:cell ratios had a higher recovery percentages, this particular ratio was chosen to maximize the efficiency of cell separation but minimize total cost of beads per treatment. We found that a one-hour incubation maximized the removal efficiency of live cells and minimized cell lysis based on microscopic observation. The number of wash steps needed to remove the bead-cell complexes was reduced from five to three. Three washes on the magnetic 
particle concentrator maximized the recovery efficiency and minimized the recovery of non-target background material. Also, by reducing the number of washes, cell breakage was kept to a minimum.

Biochemical Analyses. Once a protocol for cell separation was optimized, the recovered cells were analyzed for several biochemical parameters. The most successful analyses were chlorophyll and protein per cell determinations, for which the measurements on separated cells were not significantly different from untreated cell controls that received no bead treatment. However, it is evident from some variations in carbohydrate and C and $\mathrm{N}$ cell measurements that the addition of antibodies and beads can significantly modify the biochemical yield when compared to untreated cells.

Some significant variability between bead treated and untreated control cells was also observed during the elemental $\mathrm{C}$ and $\mathrm{N}$ determinations or $\mathrm{C}: \mathrm{N}$ ratios (Table 2.6 and 2.7). Due to the high carbon content of the magnetic beads, the majority of the carbon signal obtained from bead-treated cell samples was primarily associated with the excess unattached beads that were collected along with the cell-bead complexes (Table 2.6). Therefore, the effect of the removal of excess beads after bead separation was examined using a $20 \mu \mathrm{m}$ Nitex sieve. The large decrease in the background/control bead $\mathrm{C}$ signal after the excess beads (unbound beads) were removed resulted in a more accurate assessment of $\mathrm{C}$ and $\mathrm{N}$ per cell and $\mathrm{C}: \mathrm{N}$ ratios. However, it should be noted that the resulting $\mathrm{C}: \mathrm{N}$ ratios using $\mathrm{N}$-replete and $\mathrm{N}$-deplete bead treated cells did indicate differences in nutritional status, where $\mathrm{N}$-replete and $\mathrm{N}$-deplete $\mathrm{C}: \mathrm{N}$ ratios varied between 6.4- 
6.8 and $12-16$, respectively. I conclude that for the determination of accurate cellular C and $\mathrm{N}$ values it is necessary to remove the excess beads in order to reduce the "background" C signal.

Chlorophyll $a$ and protein analyses are less affected by the number of excess beads, since the beads contain no pigments and only small amounts of protein are associated with the antibodies ( $\mathrm{SaM}$ ) attached to the bead surface. One possible explanation for the problematic results obtained when attempting to measure cellular carbohydrate content after bead treatment may relate to bead composition. The next step in reevaluating the carbohydrate analysis of bead treatments would be to use sieving to remove excess beads prior to carbohydrate analysis, as used for the measurement of cellular $\mathrm{C}$ and $\mathrm{N}$ (Table 2.7).

Summary: The procedures presented here offer two possible methods for detecting and isolating Alexandrium fundyense from field populations. Flow cytometry in particular offers special advantages to phytoplankton researchers with respect to speed, flexibility, and detection capabilities, for example the potential use of such a technique for use in an early warning system to detect toxic marine phytoplankton species at low cell concentrations. However, with the large number of toxic species that can be identified immunologically, it is also possible to combine the use of surface MAb or PAb identification methodologies with probes that describe the physiological status of the cells in laboratory or field conditions. For example, the $\mathrm{CO}_{2}$ - fixing enzyme Rubisco has been measured flow cytometrically in the diatom Thalassiosira weisflogii and the prymnesiophyte Iso- 
chrysis galbana using a PAb directed against Rubisco in order to estimate photosynthetic rates of marine phytoplankton (Orellana and Perry 1992; Orellana and Perry 1995). To date there have been no studies that have combined the use of immunological probes with physiological probes or indicators (Jochem 2000). With the production of new and brighter fluorochromes and further enhancements of species-specific cell sorting and separating, species-specific physiological data may be obtained rapidly and more reliably than with methods used currently.

The use of immunomagnetic separation for determining the biochemical or intracellular status of Alexandrium fundyense is promising as long as certain precautions are used, such as the removal of excess beads. Now that this separation method has been optimized and enhanced in the laboratory with spiked field samples a true test of this method will be to examine natural Alexandrium populations. The combined use of immunomagnetic bead separation techniques and flow cytometry could provide a rapid approach to detecting, separating and evaluating the nutritional status of Alexandrium in the field. 


\section{ACKNOWLEDGEMENTS}

We would like to thank A. Aguilera, D. M. Kulis, R. Olson, for many helpful suggestions and technical assistance. We also thank G. Paridis at the MIT Flow Cytometry Facility and M. Sieracki from Bigelow Ocean Sciences Laboratory technical assistance with the flow cytometry and image analysis. We thank J. J. Cullen, J. G. MacIntyre, C. Ryan for use and technical assistance required for CHN analysis. This research was supported by U.S. ECOHAB Program National Science Foundation Grant OCE - 9808173, NOAA Grant NA96OP0099 and the EPA Star Graduate Fellowship U-915038-01-0 (to NP). Contribution No. \# from the Woods Hole Oceanographic Institution. 


\section{REFERENCES}

Adachi, M., Y. Sako, Y. Ishida, D. M. Anderson and B. Reguera (1993). "Crossreactivity of five monoclonal antibodies to various isolates of Alexandrium as determined by an indirect immunofluorescence method." Nippon Suisan Gakkaishi 59(10): 1807.

Aguilera, A., S. Gonzalez-Gil, B. A. Keafer and D. M. Anderson (1996). "Immunomagnetic separation of cells of the toxic dinoflagellate Alexandrium fundyense from natural plankton samples." Mar. Ecol. Prog. Ser. 143: 255-269.

Aguilera, A., B. A. Keafer, G. H. Rau and D. M. Anderson (in press). "Immunomagnetic isolation of live and preserved Alexandrium fundyense cells: Species-specific physiological, chemical, and isotopic analyses." Mar. Ecol. Prog. Ser.

Anderson, D. M., B. A. Keafer, D. M. Kulis, R. M. Waters and R. Nuzzi (1993). “An immunofluorescent survey of the brown tide chrysophyte Aureococcus anophagefferens along the northeast coast of the United States." J. Plankton Res. 15(5): 563-580.

Bates, S. S., C. Léger, B. A. Keafer and D. M. Anderson (1993). "Discrimination between domoic-acid-producing and nontoxic forms of the diatom Pseudonitzschia pungens using immunofluorescence." Mar. Ecol. Prog. Ser. 100: 185-195.

Chang, F. H., I. Garthwaite, D. M. Anderson, N. Towers, R. Stewart and L. MacKenzie (1999). "Immunofluorescent detection of a PSP-producing dinoflagellate, Alexandrium minutum, from Bay of Plenty, New Zealand." N. Z. J. Mar. Freshwat. Res. 33(4): 533-543.

Chisholm, S. W., E. V. Armbrust and R. J. Olson (1986). The individual cell in phytoplankton ecology: cell cycles and applications to flow cytometry. In: T. Platt and W. K. W. Li (eds.) Photosynthetic picoplankton. Canadian Bulletin of Fisheries and Aquatic Sciences. 214: 343-369.

Chisholm, S. W., R. J. Olson, E. R. Zettler, R. Goericke, J. B. Waterbury and N. A. Welschmeyer (1988). "A novel free-living prochlorophyte abundant in the oceanic euphotic zone." Nature 334: 340-343. 
Costas, E. and V. Lopez-Rodas (1996). "Enumeration and separation of the toxic dinoflagellate Alexandrium minutum from natural samples using immunological procedures with blocking antibodies." J. Exp. Mar. Biol. Ecol. 198: 81-87.

Dorsey, T. E., P. MacDonald and O. A. Roels (1978). "Measurement of phytoplankton protein content with the heated biuret folin assay." J. Phycol. 14: 167-171.

Dubois, M., K. A. Gilles, J. K. Hamilton, P. A. Rebers and F. Smith (1956). "Colorimetric method for determination of sugars and related substances." Anal. Chem._28: 350356.

Graneli, E., D. M. Anderson, P. Carlsson and S. Y. Maestrini (1997). "Light and dark carbon uptake by Dinophysis-species in comparison to photosynthetic and heterotrophic dinoflagellates." Aquatic Microbial Ecology 13: 177-186.

Guillard, R. R. L. (1975). Culture of phytoplankton for feeding marine invertebrates. In: W. L. Smith and M. H. Chanley (eds.) Culture of marine invertebrate animals. pp. 2960, Plenum Publishing Corp.

Haukanes, B. and C. Kvam (1993). "Application of magnetic beads in bioassays." Biotechnology 11: 60-63.

Hiroishi, S., A. Uchida, K. Nagasaki and Y. Ishida (1988). "A new method for identification of inter- and intra-species of the red tide algae Chattonella marina (Raphidophyceae) by means of monoclonal antibodies." J. Phycol. 24(3): 442-444.

Hofstraat, J. W., W. J. M. v. Zeijl, M. E. J. d. Vreeze, J. C. H. Peeters, L. Peperzak, F. Colijn and T. W. M. Rademaker (1994). "Phytoplankton monitoring by flow cytometry." J. Plankton Res. 16(9): 1197-1224.

Jochem, F. J. (2000). "Probing the physiological state of phytoplankton at the single-cell level." Sci. Mar. 64(2): 183-195.

Jonker, R. R., J. T. Meulemans, G. B. J. Dubelaar, F. Wilkins and J. Ringelberg (1995). "Flow cytometry: a powerful tool in analysis of biomass distributions in phytoplankton." Wat. Sci. Tech. 32: 177-182. 
Li, W. K. W. (1994). "Primary production of prochlorophytes, cyanobacteria, and eucaryotic ultraphytoplankton: Measurements from flow cytometric sorting." Limnol. Oceanogr. 39(1): 169-175.

Li, W. K. W. (1997). "Cytometric diversity in marine ultraphytoplankton." Limnol. Oceanogr. 42(5): 874-880.

Lowry, O. H., N. J. Rosebrough, A. L. Farr and R. J. Randall (1951). "Protein measurement with the folin phenol reagent." J. Biol. Chem. 193: 265-275.

Mendoza, H., V. López-Rodas, S. González-Gil, A. Aguilera and E. Costas (1994). “The use of polyclonal antisera and blocking of antibodies in the identification of marine dinoflagellates: species-specific and clone-specific antisera against Gymnodinium and Alexandrium." J. Exp. Mar. Biol. Ecol.186: 103-115.

Miller, P. E. and C. A. Scholin (1996). "Identification of cultured Pseudo-nitzschia (BACILLARIOPHCEAE) using species-specific LSU rRNA-targeted fluorescent probes." J. Phycol. 32: 646-655.

Olson, R. J., S. W. Chisholm, E. R. Zettler and E. V. Armbrust (1988). "Analysis of Synechococcus pigment types in the sea using single and dual beam flow cytometry." Deep-Sea Res. 35(3): 425-440.

Orellana, M. V. and M. J. Perry (1992). "An immunoprobe to measure Rubisco concentrations and maximal photosynthetic rates of individual phytoplankton cells." Limnol. Oceanogr. 37(3): 478-490.

Orellana, M. V. and M. J. Perry (1995). "Optimalization of immunofluorescent measurement of an internal enzyme, ribulose-1,5-biphosphate carboxylase (Rubisco), in single phytoplankton cells." J. Phycol. 31: 785-794.

Phinney, D. A. (1983). "Flow cytometry and cell sorting in marine phytoplankton research: Redefining measurements per cell." J. Phycol. 19: 10.

Peeters, J. C. H., G. B. J. Dubelaar, J. Ringelberg and J. W. M. Visser (1989). “Optical Plankton Analyzer: A flow cytometer for plankton analysis, I: Design considerations." Cytometry 10: 529-539. 
Peperzak, L., E. G. Vrieling, B. Sandee and T. Rutten (2000). "Immuno flow cytometry in marine phytoplankton research." Sci. Mar. 64(2): 165-181.

Rivkin, R. B. (1985). "Carbon-14 labeling patterns of individual marine phytoplankton from natural populations." Mar. Biol. 89: 135-142.

Rivkin, R. B. and H. H. Seliger (1981). "Liquid scintillation counting for ${ }^{14} \mathrm{C}$ uptake of single algal cells isolated from natural samples." Limnol. Oceanogr. 26: 780-784.

Rivkin, R. B., D. A. Phinney, C. M. Yentsch (1986). "Effects of flow cytometric analysis and cell sorting on photosynthetic carbon uptake by phytoplankton in cultures and from natural populations." Appl. Environ. Microbiol. 52(4): 935-938.

Rivkin, R. B., E. Swift, W. H. Biggley and M. A. Voytek (1984). "Growth and carbon uptake by natural populations of Pyrocystis noctiluca and Pyrocystis fusiformis." Deep Sea Res 31: 353-367.

Sako, Y., M. Adachi and Y. Ishida (1993). Preparation and Characterization of Monoclonal Antibodies to Alexandrium Species. In: T. J. Smayda and Y. Shimizu (eds.) Toxic Phytoplankton Blooms of the Sea. pp. 87-93, Elsevier Science Publishers.

Sako, Y., T. Murakami, M. Adachi, A. Uchida, Y. Ishida, M. Yamaguchi and T. Takeuchi (1996). Detection of the toxic dinoflagellates Alexandrium species by flow cytometry using a monoclonal antibody. In: T. Yasumoto, Y. Oshima and Y. FukuyoHarmful and Toxic Algal Blooms pp. 463-466, UNESCO.

Scholin, C. A., K. R. Buck, T. Britschgi, G. Cangelosi and F. P. Chavez (1996). "Identification of Pseudo-nitzschia australis (Bacillariophyceae) using rRNA-targeted probes in whole cell and sandwich hybridization formats." Phycologia 3: 190-197.

Strickland, J. D. H. and T. R. Parsons (1972). "A practical handbook of seawater analysis, 2nd ed." Bull Fish Res Bd Can 167: 1-310.

Utermöhl, H. (1958). "Neue Wege in der quantitativen Erfassung des Planktons (mit besonderer Berücksichtigung des Ultraplanktons." Verh. int. Ver. theor. angew. Limnol. 5: 567-596. 
Vrieling, E. G., W. W. C. Gieskes, W. J. M. v. Zeijl and M. Veenhuis (1994). "Detection of Gyrodinium aureolum in Dutch coastal waters by particle analysis based on immuno-flow cytometry." Netherland Journal of Aquatic Ecology 28(249-254).

Vrieling, E. G., Louis Peperzak, W. W. C. Gieskes and M. Veenhuis (1994). "Detection of the ichthyotoxic dinoflagellate Gyrodinium (cf.) aureolum and morphologically related Gymnodinium species using monoclonal antibodies: a specific immunological tool." Mar. Ecol. Prog. Ser. 103: 165-174.

Vrieling, E. G., W. W. C. Gieskes, T. W. M. Rademaker, G. Vriezekolk, L. Peperzak and M. Veehuis (1995). Flow cytometric identification of the ichthyotoxic dinoflagellate Gyrodinium aureolum in the central North Sea. In: P. Lassus, G. Arzul, E. Erard, P. Gentien and C. Marcaillou Harmful Marine Algal Blooms. pp. 743-748, Lavoisier.

Vrieling, E. G. and D. M. Anderson (1996). "Immunofluorescence in phytoplankton research: applications and potential." J. Phycol. 32: 1-16.

Vrieling, E. G., G. Vriezekolk, W. Gieskes, W.C., M. Veenhuis and W. Harder (1996). "Immuno-flow cytometric identification and enumeration of the ichthyotoxic dinoflagellate Gyrodinium Aureolum Hulburt in artifically mixed algal populations." J. Plankton Res. 18(8): 1503-1512.

Vrieling, E. G., W. H. v. d. Poll, G. Vriezekolk and W. W. C. Gieskes (1997). "Immunoflow cytometric detection of the ichthotoxic dinoflagellates Gyrodinium aureolum and Gymnodinium nagasakiense: independence of physiological state." Journal of Sea Research 37: 91-100. 
CHAPTER 3

PHYSIOLOGY AND BEHAVIOR OF ALEXANDRIUM FUNDYENSE (DINOPHYCEAE) FROM CASCO BAY, MAINE, DURING NITROGEN LIMITATION 


\section{INTRODUCTION}

Several species within the marine dinoflagellate genus Alexandrium are responsible for paralytic shellfish poisoning (PSP) along the Northeast coast of the US, Canada (Maranda et al. 1985; Cembella et al. 1987; Anderson 1989), and many other coastal regions of the world (Hallegraeff 1993). PSP occurs when shellfish accumulate the dinoflagellate toxins during feeding and pass the potent neurotoxins on to humans. Marine animals such as birds, fish, and whales can also be affected via food web toxin transfer (Geraci et al. 1989; White et al. 1989). The PSP toxins involved are called the saxitoxins, a family of nearly two dozen known derivatives (Shimizu 1993; Cembella 1998). Due to the public health, ecological and economic impacts of PSP, there is considerable interest in the ecophysiological and behavioral adaptations of Alexandrium species that not only affect their growth and bloom development, but help to define their ecological niche in the coastal environment.

A particular challenge in studying the ecophysiology of Alexandrium has been obtaining species-specific measurements at all stages of bloom development, including those times when the target Alexandrium species is only a minor component of the planktonic community. At present, most field measurements provide information on the entire plankton assemblage, for example, pigment composition (chlorophyll $a$ and accessory pigments), particulate $\mathrm{C}$ and $\mathrm{N}$, some bulk analyses and physiological estimates, such as photosynthetic performance. These can be related effectively to species abundance if the target species dominates in the natural environment. Unfortunately, Alexan- 
drium spp. are often a minor component of the phytoplankton, so their characteristics are difficult to discern. It is, therefore, difficult to examine species-specific physiological changes occurring during bloom succession, for example, following decreases in nutrient concentrations (Eppley 1981; Maestrini and Bonin 1981). In addition, behavioral adaptations, such as diel vertical migration, are also difficult to assess.

To obtain species-specific physiological measurements from field samples, cell separation methods are required. One option involves the combination of flow cytometric techniques and molecular probes, utilizing cell surface-specific antibodies or oligonucleotide probes that allow target species to be "tagged" and then sorted electronically. Thus far, this approach has been used to count a particular species in field samples (e.g., Sako et al., 1996; Vrieling et al. 1995; Vrieling et al. 1996), but the cell sorting option has not yet been used to obtain physiological measurements of harmful algal bloom (HAB) species. Another approach involves the coupling of cell surface antibodies to magnetic beads, which can then be used to remove the labeled species from plankton samples. This technique is currently under development for toxic Alexandrium species, allowing measurements of cellular of protein, chlorophyll $a(\operatorname{chl} a)$, particulate $\mathrm{C}$ and $\mathrm{N}$, and even primary production (Aguilera et al. 1996; Aguilera et al. in press; Chapter 2).

Before these methods can be utilized effectively on field populations, physiological responses to changing environmental conditions (nutrient depletion, light and temperature) need to be characterized for the species of interest, so these cell specific measurements can be interpreted. With the advent of new models, phytoplankton growth can be described as a function of both environmental variables and cellular composition 
(Geider et al. 1996; Geider et al. 1998). These models describe how irradiance, temperature, and nutrient concentration ultimately define the rates of light utilization, carbon assimilation, chl $a$ synthesis and nutrient assimilation. In turn, these rate processes determine chemical composition such as the ratio of biomass:pigment ( $\mathrm{C}: \mathrm{chl} a)$ and carbon:nitrogen $(\mathrm{C}: \mathrm{N})$. This response to changing environmental conditions is termed acclimation and can serve two potential purposes - it can increase cellular growth rate or minimize cellular death or damage caused by high irradiance, exacerbated by low temperature or low nutrient concentration (Geider et al. 1998). In addition behavioral adaptations or responses such as diel vertical migration and related changes in geotaxis and phototaxis can be related to the intracellular biochemistry and changing environmental conditions such as light and nutrient regimes (Kamykowski 1998 and Kamykowski et al. 1999). By examining these physiological and behavioral responses in toxic or harmful algal species, it may be possible to identify indicators or diagnostics of different nutritional states, such as nutrient starvation versus acclimated nutrient limitation, which help to explain patterns of species abundance, distribution, and dynamics:

For each phytoplankton species, there are different adaptations - both physiological and behavioral - that determine an organism's response to different temporal, nutritional, and hydrographic regimes (Cullen and MacIntyre 1998). To date many adaptations have been identified within natural phytoplankton communities, some behavioral and some physiological. In the former category, it has long been recognized that motility behavior of marine phytoplankton allows them to migrate through temperature gradients and exploit sources of sub-surface nutrients in the field (Eppley and Harrison 1975; 
Blasco 1978; Anderson and Stolzenbach 1985; Passow 1991) and the laboratory (Eppley et al. 1968; Kamykowski and Zentara 1976; Cullen and Horrigan 1981; Cullen et al. 1985; Rasmussen and Richardson 1989; Santos and Carreto 1992; MacIntyre et al. 1997). This exploitation of deep nutrient pools is achieved primarily through diel vertical migration (DVM), but also requires an ability to acquire nutrients in low light or in the dark (Harrison 1976; Paasche et al. 1984; Cullen and MacIntyre 1998). DVM behavior in flagellates have been shown to correlate with nitrogen availability in the water column (Eppley et al. 1968; Cullen and Horrigan 1981; MacIntyre et al. 1997) and in turn the nutritional status of the cells (Cullen and MacIntyre 1998, Kamykowski 1998). Dinoflagellates in particular are known to thrive in stable, stratified environments where there are pronounced vertical gradients of light, temperature, and nutrients (Margalef 1978). Lowenergy, stratified environments have been implicated as ideal environments for some toxic "red tide" species (Margalef et al. 1979; Therriault et al. 1985).

It was recently established that an Alexandrium isolate from the Gulf of St. Lawrence acquired nitrate in the dark and sustained growth during nocturnal descent to the nitracline in a stratified, artificial water column (MacIntyre et al. 1997). Since periods of stratification are associated primarily with low-surface-nutrient conditions following diatom blooms, the advantages of vertical migration behavior are considered an adaptive strategy or competitive advantage that allows some toxic dinoflagellate species to persist longer than non-motile phytoplankton incapable of migration.

Although behavior is thought to influence the ecophysiology of toxic dinoflagellate populations, modifications to intracellular biochemistry resulting from changes in 
nutrient availability need to be examined. At present it is difficult to measure or characterize nutrient limitation in the natural environment. For unialgal cultures, $C: P$ or $C: N$ ratios are useful parameters to distinguish between nitrogen and phosphorous limitation (Sakshaug and Holm-Hansen 1977), but these do not always provide a clear answer in field conditions due to interspecific variation and contamination from detritus. Another approach has been to identify physiological diagnostics or indicators, such as a specific protein that increases or decreases during a specific nutrient stress (i.e., nitrogen, phosphorous or iron) (Entsch et al. 1983; LaRoche et al. 1993; Erdner et al. 1999). Diagnostics, such as glutamine:glutamate (GLN/GLU) (Flynn et al. 1989; Flynn et al. 1996) and ferredoxin:flavodoxin (Fd index) (Erdner et al. 1999), have been related to specific limitations or stresses (nitrogen and iron) in laboratory cultures and in some cases have been used to monitor the natural environment (LaRoche et al. 1996; Erdner and Anderson 1999).

For Alexandrium spp., growth under different nutrient conditions ( $\mathrm{N}$ and $\mathrm{P}$ ) has been shown to modify toxin content and composition as well as intracellular characteristics such as the C:N ratio, chl $a$, and GLN:GLU (Boyer et al. 1987; Anderson et al. 1990; Anderson et al. 1990; Flynn et al. 1994; Flynn et al. 1996; MacIntyre et al. 1997; John and Flynn 1999; Parkhill and Cembella 1999). Because many toxic dinoflagellates, including Alexandrium spp., usually inhabit coastal areas that are frequently limited by nitrogen (Ryther and Dunstan 1971; Anderson 1997; Martorano 1997), behavioral and intracellular physiological adaptations to nitrogen availability are a primary consideration. In this paper, we attempt to identify physiological diagnostics and behavioral adaptations 
to nitrogen starvation ( $\mathrm{N}$-starvation) and nitrogen limitation ( $\mathrm{N}$-acclimation) for Alexandrium fundyense from Casco Bay, Maine. We designed a series of experiments using laboratory water columns (mesocosms), nitrogen-starved (N-starved) batch cultures, and nitrogen-limited ( $\mathrm{N}$-limited), semi-continuous cultures and measured changes in toxin . content and composition, cellular biomass (carbon and nitrogen), chl $a$ content, and photosynthetic efficiency $\left(\mathrm{F}_{\mathrm{v}} / \mathrm{F}_{\mathrm{m}}\right)$ during different $\mathrm{N}$-nutritional states.

\section{MATERIALS AND METHODS}

Nitrate-stratified laboratory water columns. To examine changes in behavior and physiology of Alexandrium fundyense (strain 38-3) from Casco Bay, Maine during progressive stages of nitrogen limitation, a thermally-stratified water column was established using an opaque polyvinyl chloride (PVC) cylinder $2.10 \mathrm{~m}$ in height and $0.29 \mathrm{~m}$ in diameter (Heaney and Eppley 1981; MacIntyre et al. 1997). The cylinder was maintained in a temperature-controlled room at approximately $17^{\circ} \mathrm{C}$. The PVC cylinder was treated with ethanol and filled with Nanopure water for 24 hours and covered with clear acrylic sheet. Afterwards, the cylinder was drained and filled with modified $\mathrm{K}$ medium (Keller et al. 1987) using Sandy Cove seawater (NS, CANADA) that was sterile-filtered $(0.2 \mu \mathrm{m}$ Gelman Culture Capsule filter) directly into the cylinder. $\mathrm{NO}_{3}{ }^{-}$and $\mathrm{PO}_{4}{ }^{3-}$ concentrations were modified to $50 \mu \mathrm{M}$ and $20 \mu \mathrm{M}$ respectively, ensuring $\mathrm{N}$ would be depleted first. An artificial thermocline was established using a temperature-controlled, circulating water 
bath $\left(\mathrm{ca} .5-6^{\circ} \mathrm{C}\right.$ ) to $\mathrm{cool}$ the bottom $100 \mathrm{~cm}$ of the water column. The temperature ranged from approximately $17^{\circ} \mathrm{C}$ at the surface to $7^{\circ} \mathrm{C}$ at the bottom, representing a range of temperatures typically observed during Alexandrium blooms in Casco Bay, Maine. The temperature dropped by approximately $6-7^{\circ} \mathrm{C}$ at the $100 \mathrm{~cm}$ thermocline. Irradiance to the surface layer was provided by a $250 \mathrm{~W}$ metal halide lamp on a $14 \mathrm{~h}$ light: $10 \mathrm{~h}$ dark cycle. The light period was between the hours of 08:00 and 22:00 $\mathrm{h}$. Prior to cell inoculation, the in-situ irradiance was measured using a Li-Cor (Li 185B) $4 \pi$ PAR photometer and ranged from $180 \mu \mathrm{mol}$ quanta $\mathrm{m}^{-2} \mathrm{~s}^{-1}$ at the surface to $17 \mu \mathrm{mol}$ quanta $\mathrm{m}^{-2} \mathrm{~s}^{-1}$ at the bottom. An inoculum consisting of six, 2-L cultures of exponentially growing Alexandrium fundyense (strain 38-3) in nutrient-replete modified K medium was grown at $140 \mu \mathrm{mol}$ quanta $\mathrm{m}^{-2} \mathrm{~s}^{-1}$ using cool white fluorescent lamps on a $14 \mathrm{~h}$ light: $10 \mathrm{~h}$ dark cycle. On Day 0 the inoculum was added to the surface of the water column. The water and cells were thoroughly mixed using gentle aeration (air was filtered through a $0.2 \mu \mathrm{m}$ filter prior to entering the tank) from the bottom of the tank. The initial cell concentration in the tank was approximately $2.0 \times 10^{2}$ cells $\mathrm{ml}^{-1}\left(15-20 \mu \mathrm{g} \mathrm{L}^{-1} \mathrm{chl} a\right)$.

The tank was sampled and the temperature monitored using methods previously described by MacIntyre et al. (1997). Briefly, a single length of silicone tubing (1.6 mm internal diameter) was run through a Turner Designs fluorometer, looped back on itself to create an inflow and an outflow, and lowered into the mesocosm through a small opening in the acrylic cover. Fluorescence readings were obtained every $20 \mathrm{~cm}$ as water was pumped through the fluorometer at ca. $30 \mathrm{ml} \mathrm{min}^{-1}$ using a Masterflex peristaltic pump (Cullen and Horrigan 1981). Discrete samples ( 300 - 400 ml each) were collected at 
predetermined depths of $0,60,120$ and $180 \mathrm{~cm}$ representing the features in the fluorescence or temperature profile. The samples were used to determine cell density, chl $a$, fluorescence before $\left(F_{0}\right)$, and after $\left(F_{m}\right)$ the addition of the photosynthetic inhibitor DCMU [3-(3,4-dichlorophenyl)-1,1-dimethylurea], particulate C and N, carbohydrate content, protein content, PSP toxins, and inorganic macronutrient concentrations $\left(\mathrm{NO}_{3}^{-}\right.$, $\mathrm{NO}_{2}, \mathrm{NH}_{4}{ }^{+}$). Cell densities were determined from buffered formalin-preserved cell samples (5\% final concentration; v/v) with a Coulter Multisizer II Particle Analyzer using an aperture of $70 \mu \mathrm{m}$ (Coulter Counter Ltd. GB). In addition, $1.5 \mathrm{ml}$ surface samples were preserved in Utermöhl's solution (Utermöhl, 1958) for backup (long term storage) and comparison to the multisizer cell counts. In order to maintain the volume of medium in the tank, cooled replacement medium ( $\mathrm{K}$ medium with $0 \mu \mathrm{M} \mathrm{NO}_{3}{ }^{-}$and $20 \mu \mathrm{MPO}_{4}{ }^{3 \cdot}$ ) was added every other day to the bottom layer of the tank after the 21:00 h sample. The $A$. fundyense strain utilized was not axenic. However, samples were observed frequently using light microscopy $(400 \mathrm{x})$ to verify that the bacterial population was low.

Two separate mesocosm experiments were performed, both began with the same initial conditions as described previously. The first mesocosm lasted 38 days and measured changes in Alexandrium nutrient physiology and behavior using only one surface light level. During the first mesocosm the temperature profile throughout the water column was increased to monitor behavioral changes. A second mesocosm experiment was conducted that lasted 25 days that monitor changes in behavior and physiology during increasing surface irradiances. 
During the first mesocosm experiment, samples were collected twice a day at 02:00 and 14:00 (middle of the dark and light periods) for the first 3 days, then sampling was increased to 4 times per day at 02:00, 07:00, 14:00 and 21:00 (to include the end of the light and dark periods). Samples for analysis of particulate $\mathrm{C}$ and $\mathrm{N}$, carbohydrate, protein, and PSP toxins were collected at the chl $a$ fluorescence maximum twice a day. The temperature profile was modified on Day 22 to monitor temperature-dependent changes in behavior of Alexandrium. The surface temperature was increased to approximately $21{ }^{\circ} \mathrm{C}$ and the circulating water bath temperature was increased to $12{ }^{\circ} \mathrm{C}$ causing the bottom layer temperature to increase to $14^{\circ} \mathrm{C}$ (Figure $3.1 \mathrm{E}$ ).

On Day 27 and 28 in the first mesocosm, Alexandrium nitrate uptake rates were measured during the light and dark to determine whether there was a factor in the deep water that would prevent nitrate uptake at night. Surface subsamples were removed and either enriched with nitrate (final concentration $25 \mu \mathrm{M}$ ) or mixed 1:1 with medium from below the thermocline ( $\sim 40 \mu \mathrm{M}$ nitrate) such that the initial nitrate concentration was $\sim 20$ $\mu \mathrm{M}$. The nitrate-spiked samples were incubated for 10 hours during either the light or dark period. Nitrate uptake rates (normalized to cell $\mathrm{N}$ ) were calculated using the following equation:

$$
\mu \operatorname{molNO} O^{-} / \mu \operatorname{mol} N / h=\frac{\left[N_{B}\right]-\left[N_{A}\right]}{[N]} \bullet h^{-1}
$$

where $\left[N_{B}\right]$ was the initial nitrate concentration $(\mu \mathrm{M})$ prior to the light or dark incubation and $\left[N_{A}\right]$ was the nitrate concentration after a designated number of hours $(h) .[N]$ is the particulate nitrogen concentration $\left(\mu \mathrm{mol} \mathrm{l} \mathrm{l}^{-1}\right)$ at the beginning of the light or dark incuba- 
tion. On Day 30 of the first mesocosm experiment, $\mathrm{N}$-replete medium was added to the surface layer in order to release the cells from N-stress. The mesocosm was monitored for behavioral modification and changes in the intracellular chemical composition for an additional 8 days (Days 31-38).

The second mesocosm experiment was conducted for 25 days and measured changes in the behavior of Alexandrium at different light levels, to determine if the light level used was a critical factor during the first experiment (Figure 3.2). The experimental setup was identical except that the initial irradiance was increased to $\sim 350 \mu$ mol quanta $\mathrm{m}^{-2} \mathrm{~s}^{-1}$. Samples were collected every 2-3 days, twice daily at 02:00 and 14:00, and periodically four times a day, at 02:00, 07:00, 14:00 and 21:00. Samples were collected at 0, $60,120,180 \mathrm{~cm}$ to determine cell density, chl $a$, fluorescence before $\left(F_{o}\right)$ and after $\left(F_{m}\right)$ the addition of DCMU, and for macronutrient concentrations $\left(\mathrm{NO}_{3}^{-}, \mathrm{NO}_{2}^{-}, \mathrm{NH}_{4}^{+}\right)$. On Day 15 , the surface irradiance was further increased to $\sim 500 \mu \mathrm{mol}$ quanta $\mathrm{m}^{-2} \mathrm{~s}^{-1}$ and on Day 16 to $\sim 800 \mu \mathrm{mol}$ quanta $\mathrm{m}^{-2} \mathrm{~s}^{-1}$. As in the previous mesocosm experiment, replacement media was periodically added to the bottom layer after the 21:00 timepoint.

Nitrate Starvation and Uptake Rates. The effects of nitrate starvation in batch cultures on the uptake rates of $\mathrm{NO}_{3}{ }^{-}$in the light and dark and on the intracellular chemical composition of Alexandrium were measured using cultures grown in, 2.5-L Fernbach flasks. Three Casco Bay A. fundyense isolates (strains: 38-3, CB-307 \& CB-501) were tested to determine if different isolates have different physiological responses to $\mathrm{N}$ starvation. Isolate 38-3 was examined previously during the mesocosm experiments. CB-307 and CB-501 were isolated from germinated cysts from Casco Bay, and rendered 
FIGURE 3.1. Profiles of nitrate, $\operatorname{chl} a$, and temperature during the first laboratory mesocosm on different days. (A \& B) shows the temporal changes in the nitrate concentration with depth (each symbol represents a different day). (C \& D) represents fluorescence profiles of cellular abundance displayed as chl $a$ concentration (each symbol represents a different time of day). (E) temperature profiles during different phases of the first laboratory mesocosm; $(\boldsymbol{D})$ represents temperature prior to Day $22,(\mathrm{O})$ represents temperature after-Day 22. 

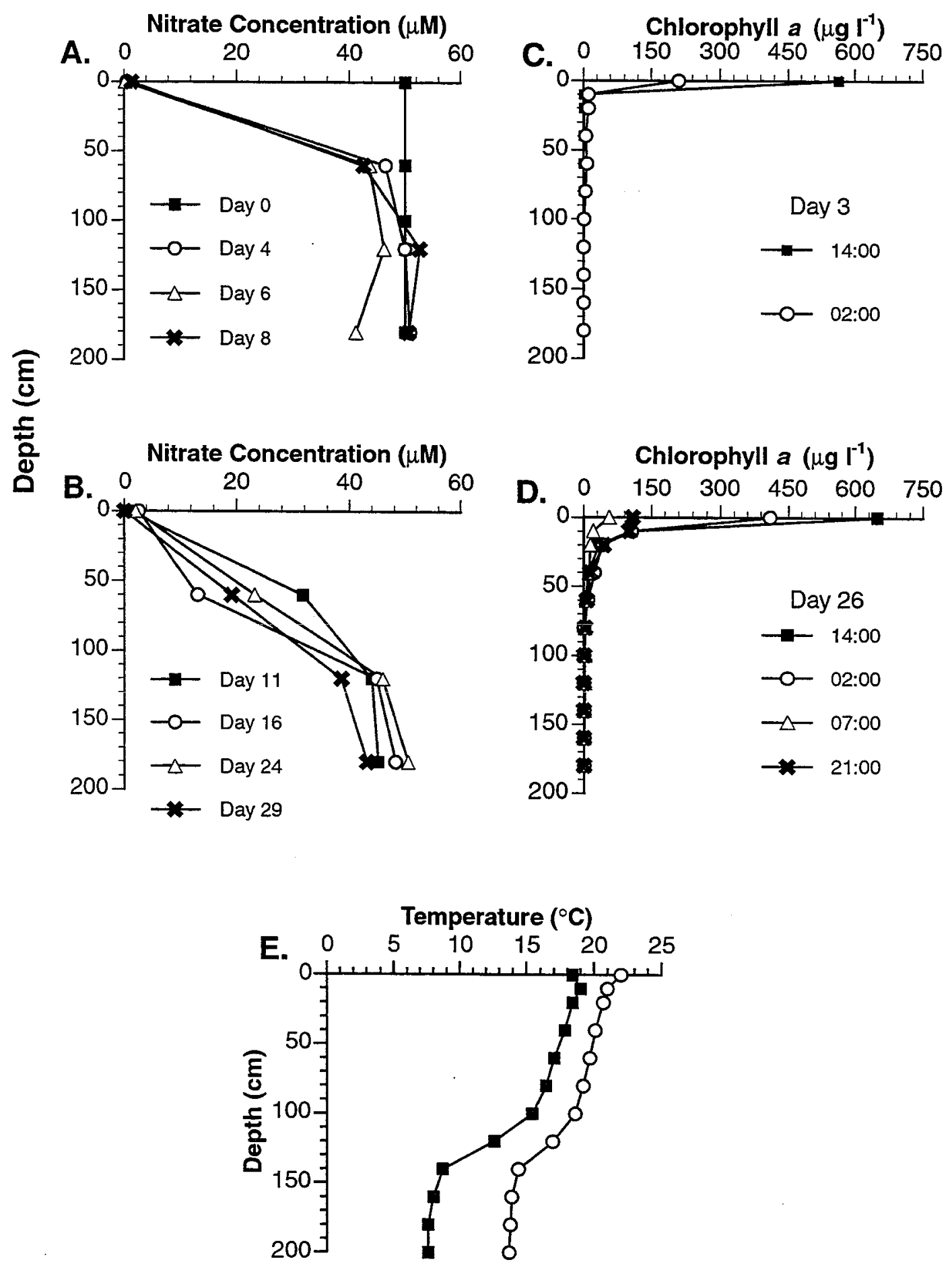
FIGURE 3.2. Profiles of nitrate, $\operatorname{chl} a$, and temperature during the second laboratory mesocosm on different days. (A \& B) are the temporal shift in the nitrate concentration with depth (each symbol represents a different day). (C \& D) represents fluorescence profiles of cellular abundance displayed as chl $a$ concentration (each symbol represents a different time of day). (E) Changes in the $\mathrm{F}_{\mathrm{v}} / \mathrm{F}_{\mathrm{m}}$ ratio within the surface layer only during the second mesocosm experiment. The incremental light levels are delimited by vertical lines. Error bars for $F_{v} / F_{m}$ are mean $\pm S E, n=3$. 


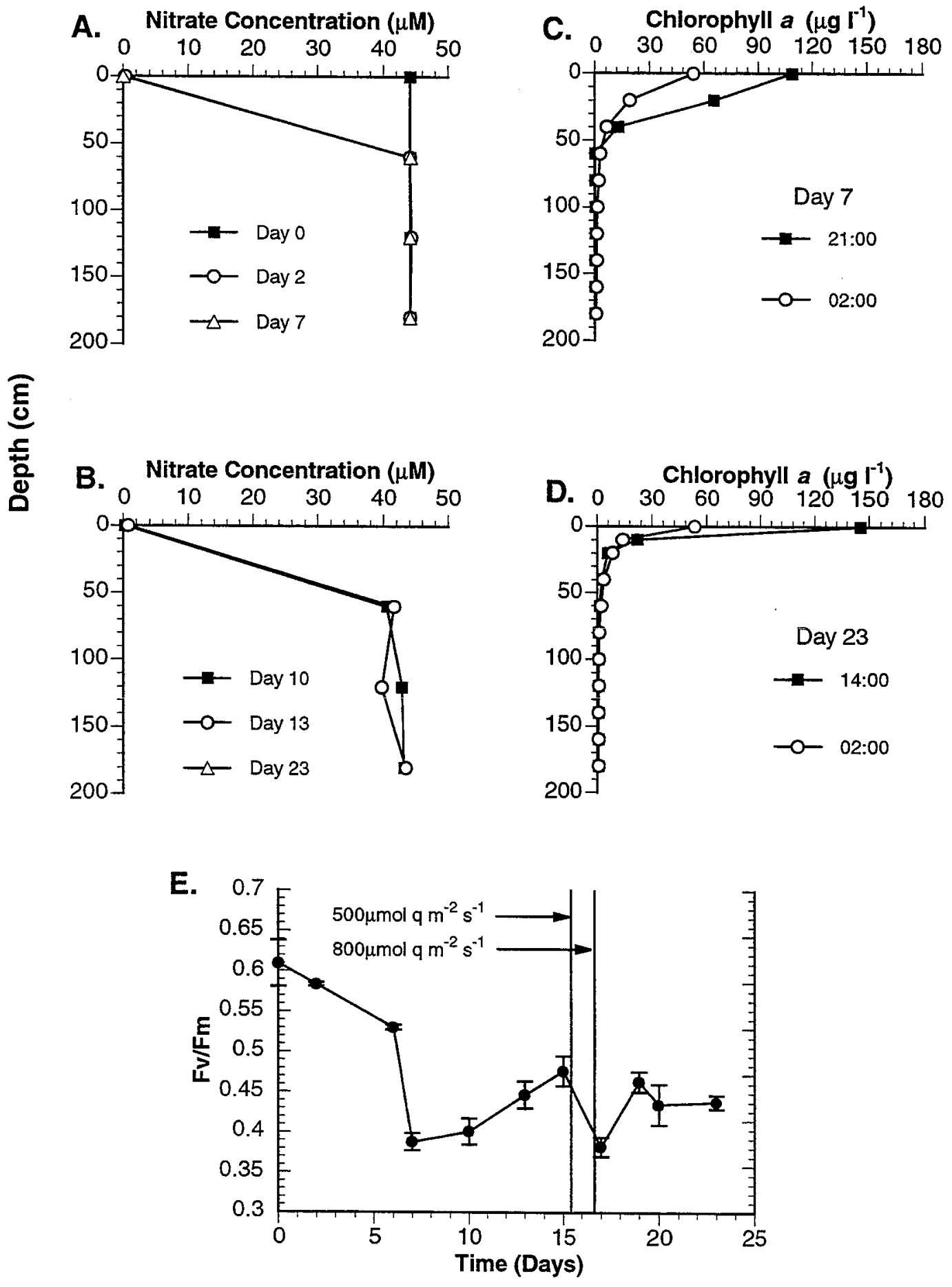


clonal by isolating a single swimming daughter cell. Each of the six Fernbach flasks contained $2 \mathrm{~L}$ of sterile, low-nitrate modified $\mathrm{K}$ medium $(60 \mu \mathrm{M})$. All other primary nutrients such as $\mathrm{PO}_{4}{ }^{3 \cdot}$ were in excess to ensure that the cells would not exhaust any other nutrient besides nitrate. Inocula of each strain were grown in nutrient-replete modified $\mathrm{K}$ medium, and utilized once the cultures reached mid-exponential growth phase. For each Alexandrium isolate tested, duplicate flasks were inoculated such that the initial cell concentration was $\sim 2 \times 10^{2}$ cell ml ${ }^{-1}\left(\sim 20 \mu \mathrm{g} \mathrm{l^{-1 }} \mathrm{chl}\right.$ a). All six flasks were incubated at 17 ${ }^{\circ} \mathrm{C}$ with an irradiance of $200 \mu \mathrm{mol}$ quanta $\mathrm{m}^{-2} \mathrm{~s}^{-1}$ provided by fluorescent lamps on a $12 \mathrm{~h}$ light: $12 \mathrm{~h}$ dark cycle beginning at 09:00.

The batch culture experiment ran for 8 days and samples were collected twice a day, at the beginning of the light and dark cycle. At each timepoint, samples were collected to determine cell density, $\operatorname{chl} a, \mathrm{NO}_{3}^{-}$, particulate $\mathrm{C}$ and $\mathrm{N}$, and carbohydrate content. Cell concentrations were determined microscopically using duplicate $1.5 \mathrm{~mL}$ Utermöhl's-preserved samples (Utermöhl 1958). At least 300 cells per sample were counted in a Sedgewick Rafter counting chamber. After Day 5, once the nitrate was depleted from each of the flasks, subsamples at each timepoint were removed to measure light-and dark $\mathrm{NO}_{3}^{-}$uptake rates. These subsamples were enriched with modified $\mathrm{K}$ medium (final concentration $60 \mu \mathrm{M}$ nitrate) and samples were removed to determine the initial cell and nitrate concentrations. The spiked subsamples were incubated alongside the nitrate deplete flasks for the full duration of the light or dark period. After incubating for $12 \mathrm{~h}$, samples were removed to determine the particulate $\mathrm{C}$ and $\mathrm{N}$, cell, carbohydrate, nitrate, 
and chl $a$ concentrations. Nitrate uptake rates were calculated for three consecutive light and dark periods beginning on Day 5 at 09:00 by normalizing to cell chl $a$ as follows:

$$
\operatorname{nmol} N O_{3}^{-} / \mu g \operatorname{chl} a / h=\frac{\left[N_{A}\right]-\left[N_{B}\right]}{[\operatorname{chl} a]} \bullet h^{-1}
$$

where $\left[N_{A}\right]$ is the initial nitrate concentration prior to the light or dark incubation, $\left[N_{B}\right]$ is the nitrate concentration after a designated number of hours $(h)$, and $[c h l a]$ is the average chl $a$ concentration before and after the light or dark incubation. After nitrogen starvation occurred on Day 5 and particulate $\mathrm{C}$ and $\mathrm{N}$ was measured, nitrate uptake rates were also calculated by normalizing to the $\mathrm{N}$ concentration as described previously.

Nitrate Limitation during Balanced Growth. Nitrate-limited, semi-continuous cultures were studied to monitor the changes in intracellular composition of Alexandrium during acclimation to two N-limited growth rates (see MacIntyre et al. 1997). Four cultures of Alexandrium (strain 38-3) were grown in 2.5-L Fernbach flasks with an initial volume of 2.1-L nitrate-deficient modified $\mathrm{K}$ medium $\left(60 \mu \mathrm{M} \mathrm{NO}_{3}^{-}\right)$. All four flasks were inoculated with an initial cell concentration of $\sim 2 \times 10^{2}$ cells $\mathrm{ml}^{-1}\left(\sim 15-20 \mu \mathrm{g} \mathrm{L}^{-1} \mathrm{chl} a\right)$ and grown at $17^{\circ} \mathrm{C}$ under an irradiance of $180 \mu \mathrm{mol}$ quanta $\mathrm{m}^{-2} \mathrm{~s}^{-1}$ on a $14 \mathrm{~h}$ light: $10 \mathrm{~h}$ dark cycle using fluorescent lamps. Using replicate cultures, two different nitrate-limiting dilution rates were imposed. The replacement medium for the semi-continuous dilutions was filter-sterilized modified $\mathrm{K}$ medium with $\mathrm{NO}_{3}^{-}$adjusted to $60 \mu \mathrm{M}$. The medium was added aseptically from a 40-L carboy through a gravity-feed system (MacIntyre et al. 1997). 
For the first seven days of the experiment, all four flasks were grown as batch cultures and sampled twice daily at 08:00 and 22:00 (the beginning of the light and dark periods) to determine cell density, chl $a, \mathrm{NO}_{3}{ }^{-}$concentration, and fluorescence before $\left(\mathrm{F}_{\mathrm{o}}\right)$ and after $\left(\mathrm{F}_{\mathrm{m}}\right)$ DCMU addition $\left(\mathrm{F}_{\mathrm{v}} / \mathrm{F}_{\mathrm{m}}\right.$ - analyzed only at 22:00). After Day 4, additional samples were collected once a day, every other day, for particulate $\mathrm{C}$ and $\mathrm{N}$, carbohydrate and proteins. Cell concentrations were determined using live cells, 40 minutes after sampling, using a Coulter Multisizer II Particle Analyzer (aperture $70 \mu \mathrm{m}$ ). Due to time limitation and the culture volume required, not all samples were enumerated on the Particle Analyzer. Therefore, duplicate Utermohl's preserved cell samples were collected at all time points for microscopic analysis. At least 300 cells per sample were counted in a Sedgewick Rafter counting chamber. All cell densities represent an average of duplicate counts. There was no significant difference between the cell densities measured by the Particle Analyzer and those counted microscopically using Utermohl's preservation, so both the microscopic and Coulter counts were used. Once nitrate depletion occurred on Day 6 and the cell concentration had increased to $\sim 3000 \mathrm{cell} \mathrm{ml}^{-1}$ the dilutions commenced. The flasks were diluted twice daily, at the beginning and the end of the light period (08:00 and 22:00). Replicate flasks were diluted $30 \% \mathrm{~d}^{-1}$ and $15 \% \mathrm{~d}^{-1}$ thus dictating nitrate-limited specific growth rate of $\sim 0.3 \mathrm{~d}^{-1}$ and $\sim 0.15 \mathrm{~d}^{-1}$, respectively (note that since the flasks were diluted twice a day and growth changes with the diel phases, there will be inaccuracies in the growth rate determinations). By Day 25 , all four flasks were considered to be in steady state, as defined by MacIntyre et al. (1997). Briefly, once the cell density, chl $a$ concentration, in vivo fluorescence, and $\mathrm{F}_{\mathrm{v}} / \mathrm{F}_{\mathrm{m}}$ (see Analytical determi- 
nations) had stabilized about a constant mean $(<+20 \%)$, the cells were considered to be in a quasi-steady state. The irregularity in the nutrient supply (nitrate delivered to the cultures twice a day) and the periodicity of the lights (light/dark cycle) impose conditions that cause periodicity of phytoplankton growth and assimilation (Eppley 1981). However, if the assimilation rates are averaged over a day one can assume growth to be nearly balanced (Shuter 1979). Once acclimated growth was achieved, experimental sampling continued for an additional 15 days, twice a day, as described above.

Analytical Determinations. All discrete samples for analysis were processed the same way in all three experiments. For the determination of $\operatorname{chl} a$, samples were filtered onto Whatman GF/F glass fiber filters and extracted in $10 \mathrm{ml}$ ice-cold $90 \%$ acetone, then stored at $-20{ }^{\circ} \mathrm{C}$ for a minimum of $24-48 \mathrm{~h}$ in the dark. Chl $a$ concentrations, corrected for pheopigments, were determined using a Turner Designs fluorometer (Strickland and Parsons 1972) previously calibrated with pure chl $a$ (Sigma Chemical Co., USA). Using the chl $a$ concentrations at discrete depths $(0,60,120,180 \mathrm{~cm})$ the fluorescence measurements obtained with the flow through Turner Designs Fluorometer at intervals of 20 $\mathrm{cm}$ in the mesocosms were converted into chl $a$ values by interpolation. This produced a chl $a$ profile within the mesocosm for each sampling timepoint. The ratio $F_{v} / F_{m}$, a physiological index of relative photosynthetic efficiency (photochemical conversion efficiency of PSII; Kolber et al. 1988; Falkowski et al. 1992), was calculated as $\left(\mathrm{F}_{\mathrm{m}}-\mathrm{F}_{\mathrm{o}}\right) / \mathrm{F}_{\mathrm{m}}$ where $\mathrm{F}_{\mathrm{o}}$ is the in vivo fluorescence and $\mathrm{F}_{\mathrm{m}}$ is the in vivo fluorescence after DCMU addi- 
tion as described by MacIntyre et al. (1997). The ratio, $F_{v} / F_{m}$ was calculated at either the $14: 00 \mathrm{~h}$ or $21: 00 \mathrm{~h}$ sampling time, during the light period.

Samples for CHN, protein and carbohydrate analysis were filtered onto $25 \mathrm{~mm}$ pre-combusted (4-6 h @ 400 ${ }^{\circ} \mathrm{C}$ ) Whatman GF/F glass fiber filters and stored in liquid nitrogen. The filters were dried at $60^{\circ} \mathrm{C}$ overnight and stored until analysis for $\mathrm{C}$ and $\mathrm{N}$ on a Perkin Elmer 2400 CHN analyzer using acetanilide as a standard. Precombusted GF/F filters were used as blanks as the samples were analyzed.

Samples were analyzed for proteins using a heated, biuret folin assay developed by Lowry et al. (1951), and modified by Dorsey et al. (1978). Filtered samples were added to $13 \times 100 \mathrm{~mm}$ borosilicate glass screw-capped tubes with polypropylene caps (Fisher Scientific Co., Pittsburgh PA, USA) and resuspended in $300 \mu \mathrm{l} 0.1 \mathrm{~N}$ sodium hydroxide solution and $1.8 \mathrm{ml}$ of combined reagent (alkaline cupric tartrate). Each tube was then capped, vortexed, and heated at $95-100^{\circ} \mathrm{C}$ for $100 \mathrm{~min}$. Afterwards, $180 \mu \mathrm{l}$ of a $1 \mathrm{~N}$ Folin phenol reagent (Sigma Chemical Co., USA) was added to form a blue color. The tubes were vortexed and cooled in a $10^{\circ} \mathrm{C}$ water bath for $10 \mathrm{~min}$. After cooling the tubes sat a room temperature for $1 \mathrm{~h}$ and were read at $660 \mathrm{~nm}$ using disposable $1 \mathrm{~cm}$ acrylic cuvettes (Fisher Scientific Co. Pittsburgh, PA, USA) in a Shimadzu UV 160 spectrophotometer (Shimadzu Corp, Japan). Bovin serum albumin (BSA; Sigma Chemical Co., USA) was run as a protein standard simultaneously with precombusted glass fiber filters. Untreated precombusted filters were run simultaneously in triplicate as a sample blank.

The carbohydrate analysis was adapted from Dubois (1956). For the analysis, 400 $\mu \mathrm{l}$ of Nanopure water was added to the filtered samples in $13 \times 100 \mathrm{~mm}$ disposable bor- 
osilicate glass screw-capped tubes with polypropylene caps. Standards were prepared from a dilution series of dextrose solution $(400 \mu \mathrm{g} / \mathrm{ml})$ with precombusted glass fiber filters. To both the sample and standard tubes $500 \mu \mathrm{l}$ of phenol $(5 \% \mathrm{w} / \mathrm{v}$ in water) was added and vortexed. Afterwards, $2 \mathrm{ml}$ of concentrated sulfuric acid was added slowly to . each tube, capped, and vortexed in a fume hood. All of the tubes were heated in a $90-100$ ${ }^{\circ} \mathrm{C}$ water bath for $1 \mathrm{~h}$. The samples were read on a Shimadzu UV 160 spectrophotometer at the maximum absorbance of the highest standard $(485-490 \mathrm{~nm})$ using $1 \mathrm{~cm}$ acrylic cuvettes.

Concentrations of $\mathrm{NO}_{3}^{-}$were determined from frozen filtered (precombusted Whatman GF/F) samples of culture medium by a Technicon II Autoanalyzer (Grasshoff et al. 1976). The concentration of ammonium from a few tank experimental samples was determined colorimetrically according to Parsons et al. (1984).

Toxin Extraction and Analysis. Between $20-50 \mathrm{ml}$ of cell culture from the first mesocosm were harvested to determine saxitoxin content and composition at different times. The cells were concentrated via centrifugation (if necessary) and distributed evenly between into 2 pre-weighed, $15 \mathrm{ml}$ centrifuge tubes (Fisher Scientific Co. Pittsburgh, PA, USA). A $1 \mathrm{ml}$ volume was removed for from each duplicate $10 \mathrm{ml}$ sample and preserved in Utermöhl's solution for cell counts. The toxin samples were pelleted via centrifugation $(5000 \mathrm{x} \mathrm{g}$ for $5 \mathrm{~min})$ and the supernatant aspirated. Toxins were extracted from the cell pellet using between $0.5-1.0 \mathrm{ml} 0.5 \mathrm{M}$ acetic acid and then resuspended in the acid by gentle pipeting. Toxin extraction was completed by sonifying each sample on ice with 
a Branson sonic cell disrupter for 20 seconds at a setting of $6 \mathrm{~A}$. The algal extracts were centrifuged and the supernatants frozen at $-20^{\circ} \mathrm{C}$ prior to analysis by high-performance liquid chromatography (HPLC). Prior to analysis of toxin content and composition, the extracts were thawed, weighed, centrifuged, then loaded $(200 \mu \mathrm{l}$ each) into separate Teflon-capped, borosilicate auto-sampler vials. The total volume of each toxin sample was calculated by subtracting the final sample weight from the initial tube weight. The samples were analyzed for saxitoxins by HPLC using the three-step isocratic elution method of Oshima et al. (1989) following the modifications of Anderson et al. (1994). Toxicities (in STX equivalent cell ${ }^{-1}$ ) were calculated from the molar composition data using individual potencies (Oshima et al. 1982). The specific toxicities of individual toxins are as follows ( $\mu \mathrm{g}$ STX equiv. $\mu \mathrm{mole}^{-1}$ ): C1, 3.45; C2, 55.0; GTX1, 567.6; GTX2, 205.2; GTX3, 364.3; GTX4, 414.7; GTX5, 36.8; dcGTX3, 430.6; NEO, 527.9; STX, 571.1. All cell samples for physiological determinations and toxin extractions were performed using unpreserved cells. Toxin abbreviations used in the text are as follows: STX, saxitoxin; NEO, neosaxitoxin; GTX1,4 gonyautoxins 1 and 4; GTX 2,3 gonyautoxins 2 and 3; GTX 5, gonyautoxin 5; $\mathrm{C} 1,2$ toxins $\mathrm{C} 1$ and $\mathrm{C} 2$; dc decarbamoyl.

\section{RESULTS}

Nitrate-stratified laboratory water columns. For both tank experiments the concentration of nitrate in the surface layer (top $20 \mathrm{~cm}$ ) was rapidly depleted to less than $1.0 \mu \mathrm{M}$ from $50 \mu \mathrm{M}$ within the first three days (Figure 3.1). In the bottom layer $(120-180 \mathrm{~cm}$ ), 
below the thermocline, the nitrate level remained high $(>40 \mu \mathrm{M})$ (Figure $3.1 \& 3.2 \mathrm{~A} \&$ B). The nitrate stayed low at the surface $(<1.0 \mu \mathrm{M})$ and maintained high concentrations at depth for the duration of both mesocosm experiments, except for when nitrate was added back to the surface on Day 30 in the first mesocosm experiment. Only at the middepths $(60 \mathrm{~cm}$ ) was there a slow decrease in the amount of nitrate through time (Figure $3.1 \mathrm{~B})$.

The distribution of Alexandrium in the tank was monitored using the fluorescence profiles generated at each sampling time to observe changes in behavior. Throughout both tank experiments no vertical migration to the deep N-rich bottom layer was observed, and this result appeared to be insensitive to any temperature and light modifications (Figures $3.1 \& 3.2$ ). The cells maintained a dense surface layer both in the presence and absence of nitrate. The highest cell concentration was observed at the surface during the light period (14:00 and 21:00 h) due to Alexandrium's strong phototactic response. During the dark period (02:00 and 07:00 h) the cells were more dispersed within the upper 20-60 cm (Figure $3.1 \& 3.2$ A \& B). Significant fluorescence was not detected below $60 \mathrm{~cm}$ in either mesocosm experiment. Based on the results of MacIntyre et al. (1997) we expected the cells descend at night once the surface nitrate was depleted, causing an increase in fluorescence at depth at night with the depth of descent increasing as the nitracline deepened. In order to verify that no chemical factor prevented the uptake of nitrate in the deeper strata, duplicate 1-L subsamples from below the thermocline were removed and inoculated with cells from the surface of the mesocosm (initial chl $a$ concentration $\left.\sim 20 \mu \mathrm{g} \mathrm{L}^{-1}\right)$. The inoculated subsamples were grown under the same conditions 
as the initial inocula of the mesocosm and within 5 days the nitrate was depleted and active cell growth had occurred. In addition, on Day 28 and 29 the average light and dark nitrate uptake rates calculated were $35.0 \pm 5.0 \mathrm{nmol} \mathrm{NO}_{3}{ }^{-} \mathrm{nmol} \mathrm{N}^{-1} \mathrm{~h}^{-1}$ and $3.0 \pm 0.2 \mathrm{nmol}$ $\mathrm{NO}_{3}^{-} \mathrm{nmol} \mathrm{N}^{-1} \mathrm{~h}^{-1}$. During both the light and the dark enough $\mathrm{NO}_{3}^{-}$was consumed to grow at their maximal rate.

Large changes in the intracellular composition were observed over the course of the first mesocosm experiment. For convenience and future discussion, this mesocosm experiment was divided into three phases based on $\mathrm{N}$-availability: Phase I, N-depletion (Days 0-8); Phase II, N-acclimation (Days 9-30); and Phase III, N-restoration (Days 3138). Within the first mesocosm the chl $a$ cell $^{-1}$ values were initially high (60 pg chl $a$ cell $^{-1}$ ) during Phase I then rapidly decreased to approximately $25 \mathrm{pg}$ cell $^{-1}$ and remained constant $( \pm 15 \%)$ for the remainder of the experiment (Figure 3.3 ). Similar to the chl $a$ data the relative photosynthetic efficiency $\left(\mathrm{F}_{\mathrm{v}} / \mathrm{F}_{\mathrm{m}}\right)$ dropped dramatically within Phase I; however, after prolonged nitrate limitation in the surface layer $F_{v} / F_{m}$ increased slowly, returning to a ratio of $0.62-0.70$ (Figure 3.3).

FIGURE 3.3. Changes in chl $a$ content per cell $(\mathrm{O})$ and $\mathrm{F}_{\mathrm{v}} / \mathrm{F}_{\mathrm{m}}$ ratio $(O)$, (determined at either 14:00 or 21:00 daily) during the first mesocosm experiment. Three phases of Navailability during the experiment are labeled and delimited by the vertical lines. Phase I, represents $\mathrm{N}$-depletion; Phase II, represents $\mathrm{N}$-acclimation; and Phase III, represents $\mathrm{N}$ restoration within the surface layer of the mesocosm. Error bars for $F_{v} / F_{m}$ are the mean \pm $\mathrm{SE}, \mathrm{n}=3$. 


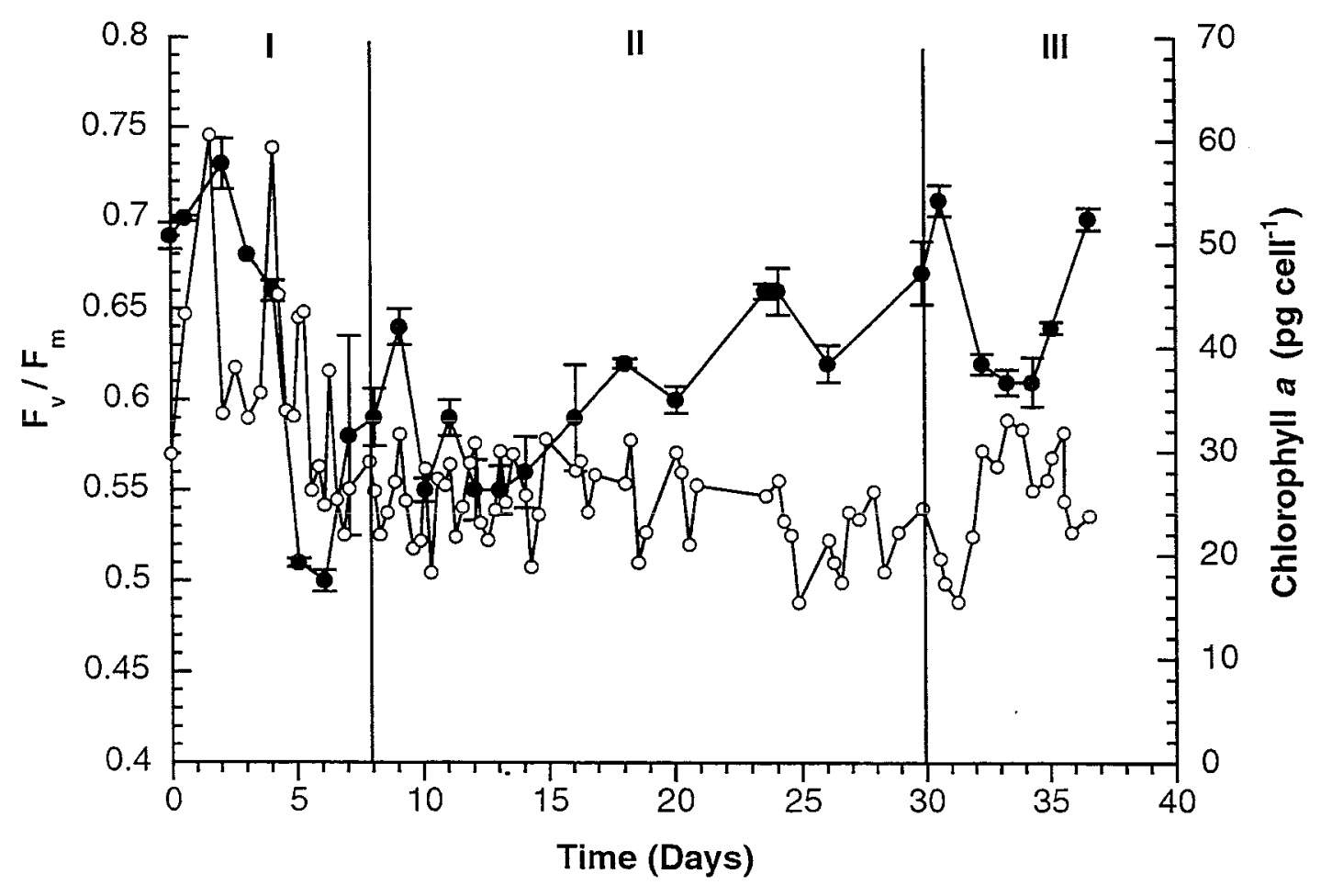


The cellular ratio of $\mathrm{C}: \mathrm{N}$, chl $a$ per cell, protein per cell and carbohydrate (CHO):chl $a$ showed rapid changes initially, then stabilized as $\mathrm{N}$-depletion continued in the surface layer of the first mesocosm experiment. Initially the C:N ratio was $6 \pm 1$ during Phase I and increased to a maximum value of $9 \pm 1$ during Phase II (Figure 3.4 A). This C:N pattern reversed itself during Phase III after the addition of nitrate to the surface layer on Day 30. Protein per cell decreased significantly within the first two days from 3 ng protein per cell to a constant mean of 1.2 ng protein per cell after Day $2( \pm 24 \%)$ (Figure $3.4 \mathrm{~B}$ ). The CHO:chl $a$ ratio increased from 10 to 20 by Day 27 , but soon after the addition of nitrate to the surface layer on Day 30 the pattern began to reverse itself (Figure 3.4 C). This strain of Alexandrium fundyense (38-3) was found to contain 10 of the numerous naturally occurring PSP toxins. In the first mesocosm the toxins found in greater than $10 \%$ overall abundance were C1, GTX 3, GTX 4, NEO and STX. The other toxins identified - C2, GTX 1, GTX 2, GTX 5 and dcGTX3 - were found in minor abundance. During the first 8-10 days of the mesocosm experiment (Phase I) the total toxin content cell ${ }^{-1}$ remained high at an average of $115 \mathrm{fmol} \mathrm{cell}^{-1}$ (Figure 3.5 A). After Day 10 the toxin content began to drop at a steady rate until Day 23 when the cellular toxicity leveled out at $62 \mathrm{fmol} \mathrm{cell}^{-1}$. Toxin content per cell decreased nearly $50 \%$ from the beginning of the experiment, as did the cellular toxicity (pg STX eq cell ${ }^{-1}$ - data not shown). After the addition of nitrate on Day 30 , the toxin content per cell recovered rapidly, back to an average of $100 \mathrm{fmol} \mathrm{cell}^{-1}$, close to the values calculated during Phase I.

Over the course of the 38 day experiment, dramatic toxin compositional changes were observed among the different saxitoxin derivatives. Since concentrations of GTX 1, 
GTX 2 and C1 were in relatively low abundance GTX $2 \& 3$, GTX $1 \& 4$ and C1 \& C2 were grouped together because they are epimeric pairs that undergo interconversion (Hall 1982; Oshima et al. 1993). During Phase I only, STX decreased rapidly at $\sim 2$ fmol cell ${ }^{-1}$ $\mathrm{d}^{-1}$. Most of the other major toxin derivatives $\mathrm{C} 1,2, \mathrm{GTX} 2,3$ and NEO did not vary significantly during Phase I, but began to decrease at the beginning of Phase II (Figure $3.5 \mathrm{~B}$ \& C). However, GTX 1,4 remained relatively constant at $12.2 \pm 1.7 \mathrm{fmol} \mathrm{cell}^{-1}$ during both Phase I and Phase II. During Phase II, C1,2, GTX 2,3 and NEO decreased at 1.5, 1.1 and 0.8 fmol cell $^{-1} \mathrm{~d}^{-1}$, respectively. After Day 23 the toxin quotas cell ${ }^{-1}$ stabilized. Upon nitrate addition to the surface layer (Day 30 - Phase III) most toxin derivatives increased to near pre-nitrate stress values or higher.

On a relative basis (mole \% total toxin) STX and C1,2 decreased from initial values of $20 \pm 2 \%$ and $30 \pm 3 \%$ to $6 \pm 1 \%$ and $20 \pm 2 \%$, respectively as nitrate stress persisted in the surface layer of the first mesocosm (Figure 3.6 A \& B). The mole \% total toxin of NEO and GTX 1,4 increased, nearly doubling their initial values by Day 30 . Changes to GTX 2,3 were less pronounced and did not vary significantly over time. Upon nitrate addition to the surface layer on Day 30, the NEO and STX profiles began to reverse themselves slowly, whereas, the GTX and C toxins did not change upon $\mathrm{N}$ addition. 
FIGURE 3.4. Changes in the cellular chemical composition status the first mesocosm experiment. (A) C:N ratio (samples taken at 14:00 or 21:00 only), (B) Cellular protein content, (C) Carbohydrate (CHO):chl $a$. Error bars for protein and $\mathrm{C}: \mathrm{N}$ are mean $\pm \mathrm{SE}$, $\mathrm{n}=3$. 


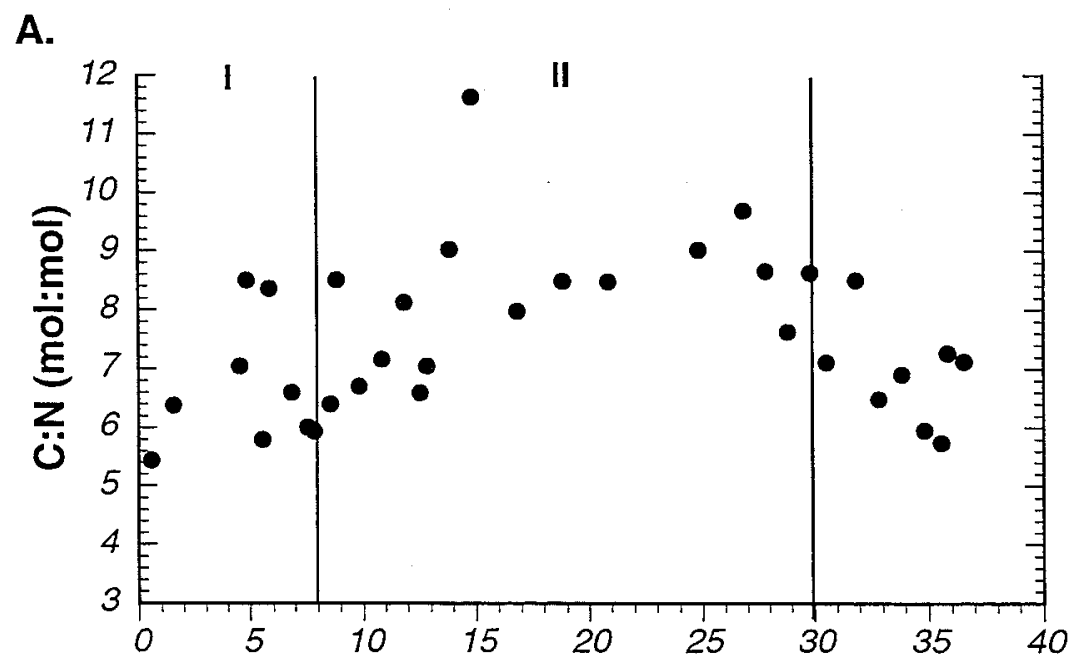

B.

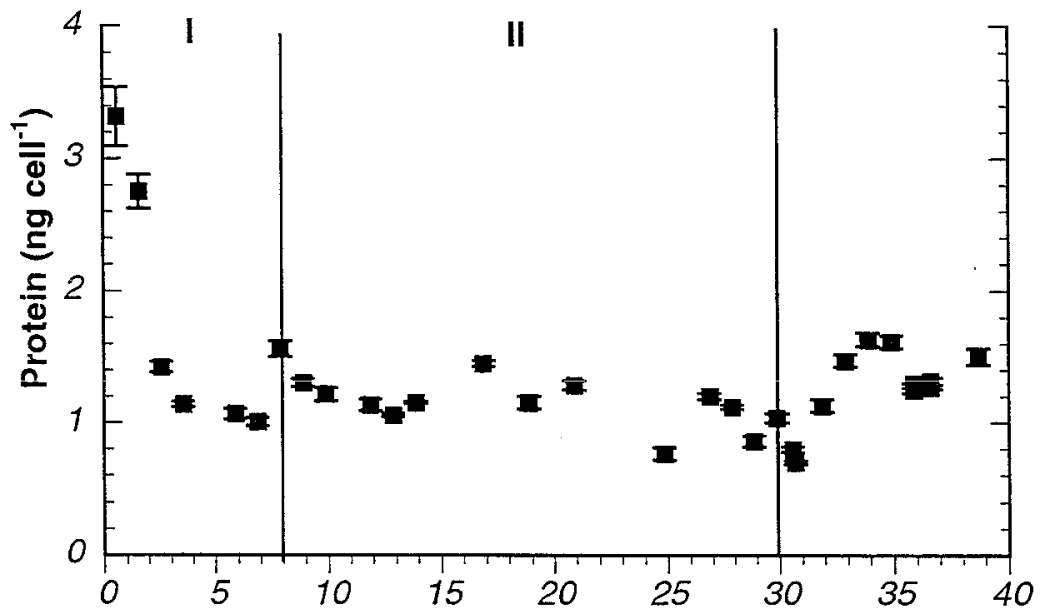

c.

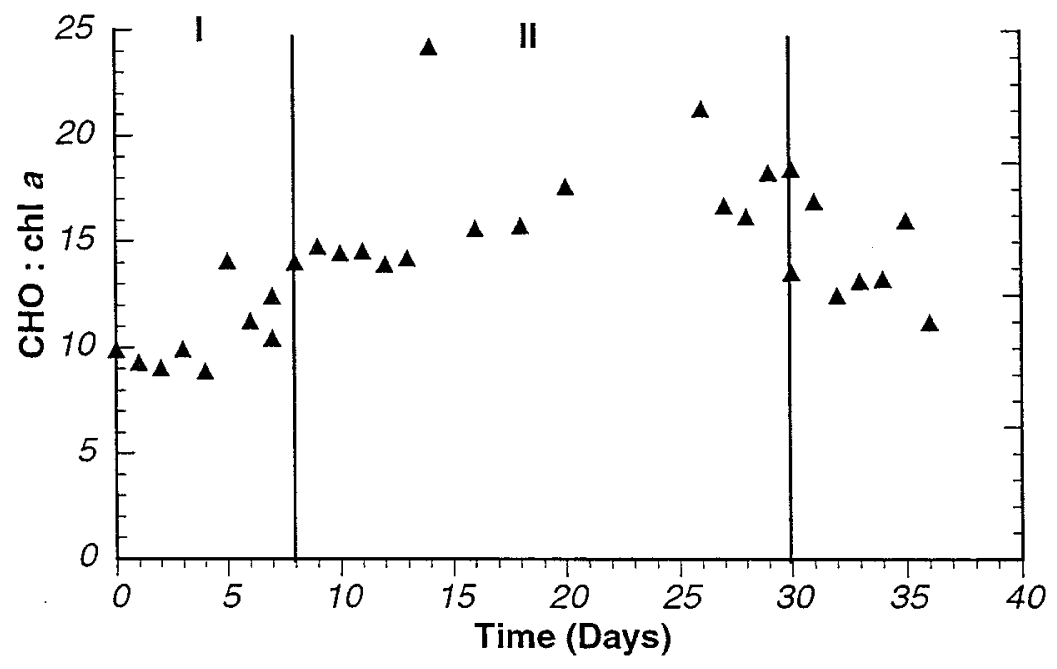


FIGURE 3.5. Changes in cellular toxin content and composition during growth in the first laboratory mesocosm. (A) toxin content ( $\mathrm{fmol}$ toxin cell $^{-1}$ ) and (B \& C) toxin profile

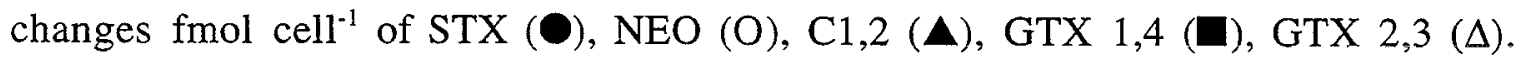


A.

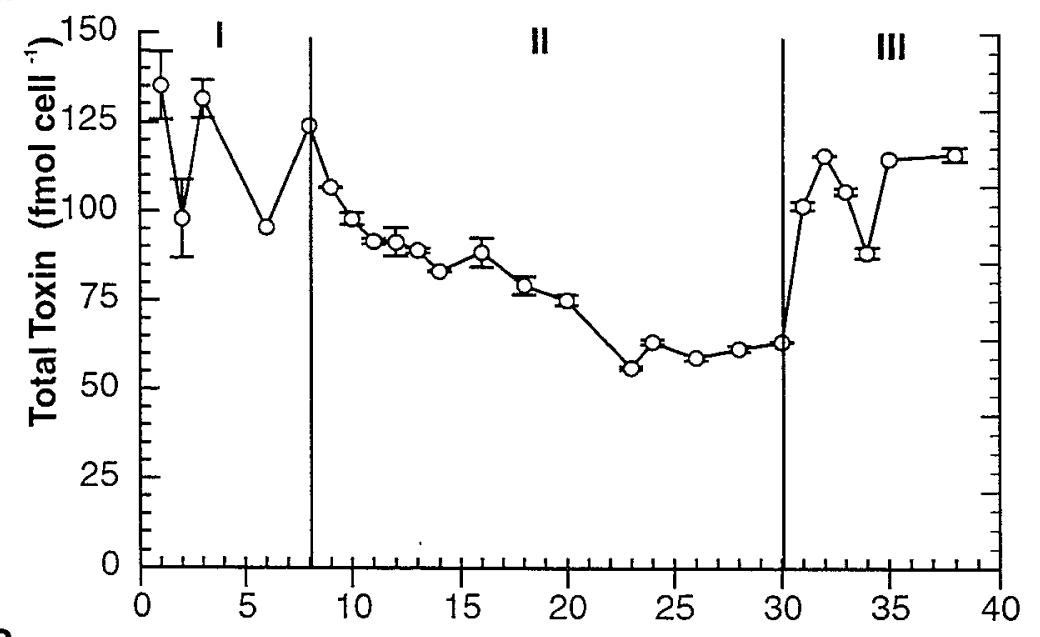

B.

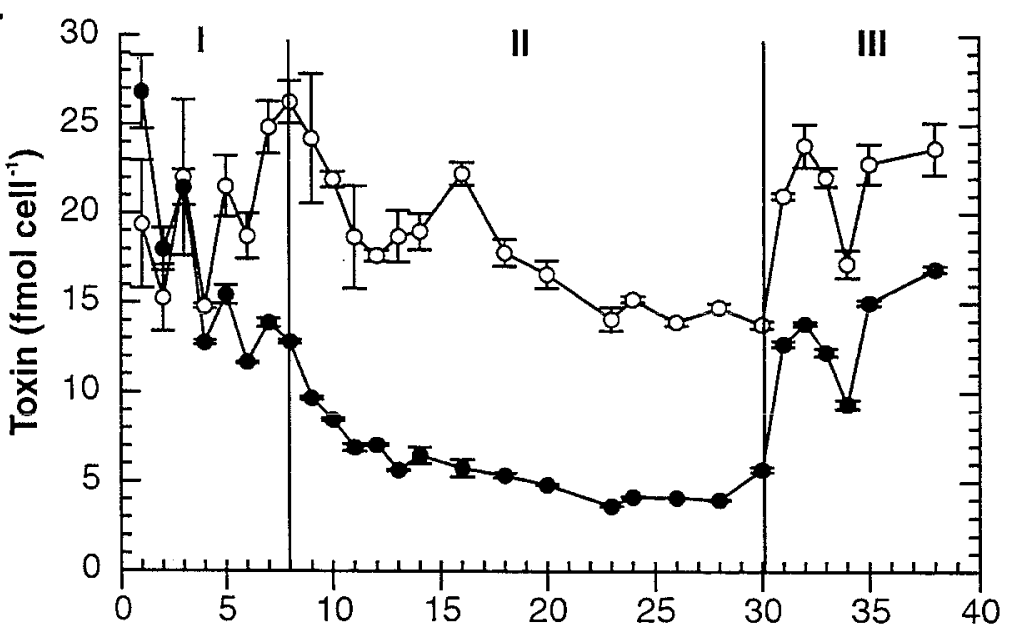

c.

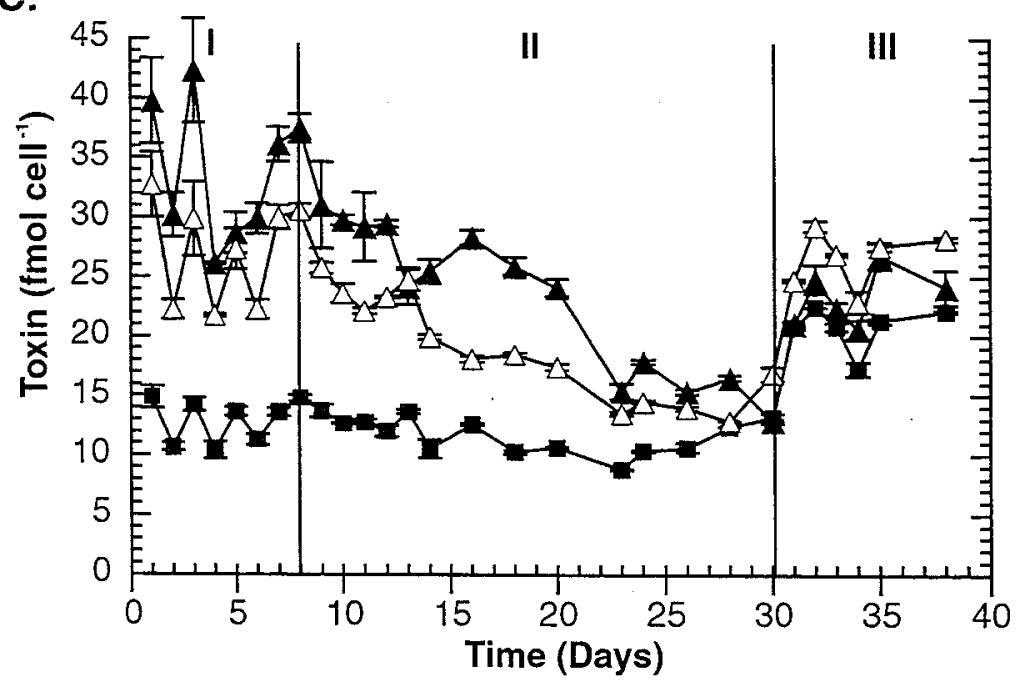


To observe trends among different toxins as nitrogen limitation in the surface layer progressed, the ratios (fmol:fmol) of two saxitoxin derivatives were calculated as follows:

$$
\text { Toxin Ratio }\left[T_{A}: T_{B}\right]=\left[\frac{T_{A}}{T_{B}}\right]
$$

where $\left[T_{A}\right]$ is the toxin concentration of derivative $A\left(\mathrm{fmol} \mathrm{cell}^{-1}\right)$ and $\left[\mathrm{T}_{B}\right]$ is the toxin concentration of derivative B (fmol cell $\left.{ }^{-1}\right)$. Significant increases over time were observed in the toxin ratios of C1,2:STX, GTX1,4:STX, NEO:STX, GTX 2,3:STX as the cells become more nutrient limited (Figure $3.7 \mathrm{~A}$ ). For each of these ratios a linear trend is observed during the first 15 days $\left(r^{2}=0.94, r^{2}=0.86, r^{2}=0.96\right.$ and $r^{2}=0.88$, respectively). However, these trends could not be verified since the experiment was not replicated. Further examination is required to show that the observed trends are statistically significant.

FIGURE 3.6. Changes in cellular toxin during the first mesocosm experiment. (A \& B) toxin profile changes or relative abundance as molar percentages of the total toxin, mole

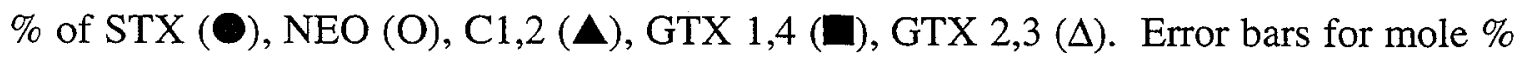
toxin are mean $\pm S D(n=2)$. 
A.
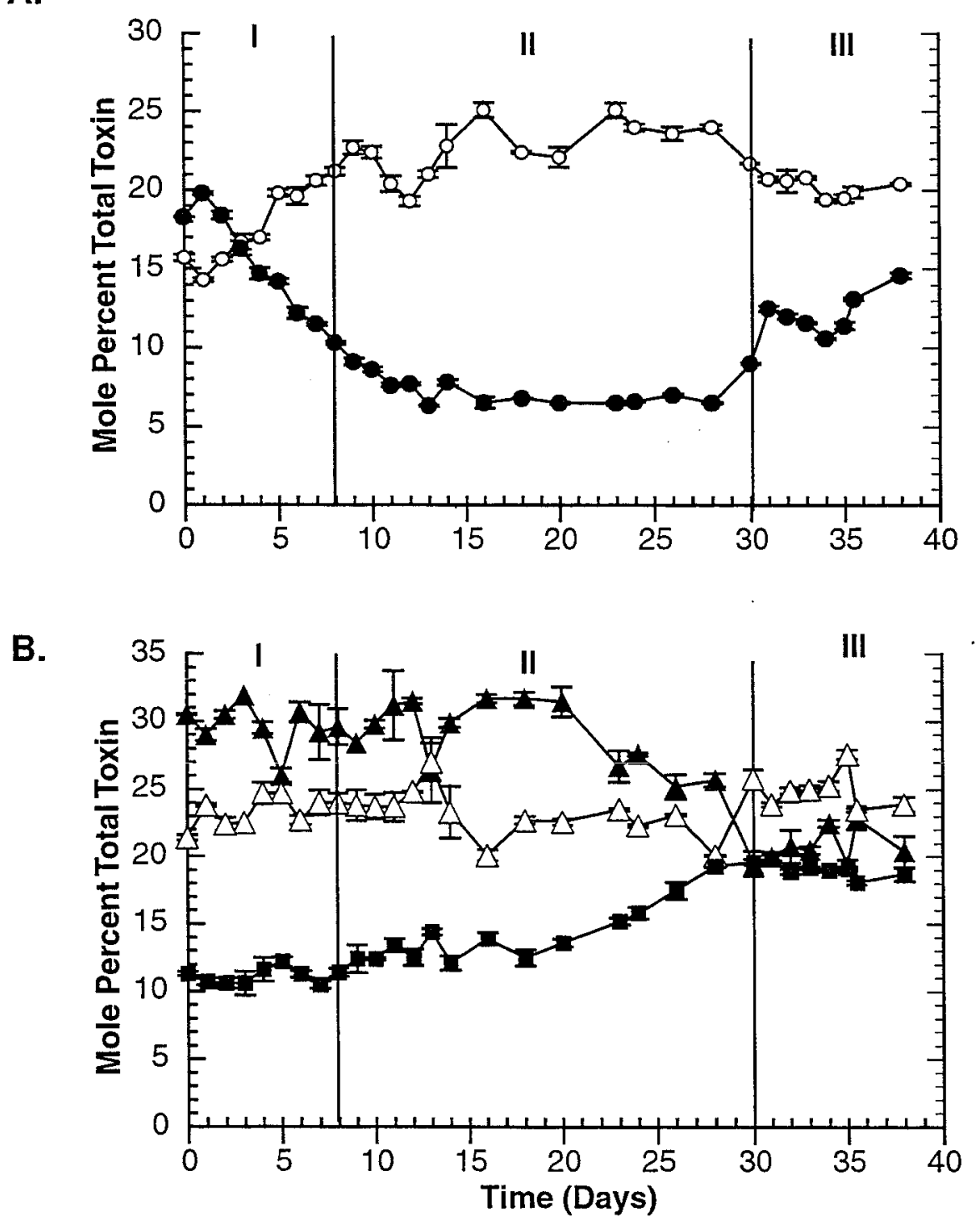
FIGURE 3.7. Toxin ratios (A \& B) for Alexandrium fundyense (strain 38-3) during the three phases of the first laboratory mesocosm experiment NEO:STX (O), GTX 1,4:STX $(\boldsymbol{\square}), \mathrm{C} 1,2: \operatorname{STX}(\Delta), \operatorname{GTX} 2,3: \operatorname{STX}(\bullet), \operatorname{GTX} 1,4: \operatorname{NEO}(\boldsymbol{\Delta}), \mathrm{C} 1,2: \mathrm{NEO}(\bullet) .(\mathbf{C} \& \mathbf{D})$ toxin ratios for $A$. fundyense (strain GTCA28) as a function of specific growth rate in Nlimited semi-continuous culture recalculated from Anderson et al. (1990b), refer to symbols in (A \& B). 

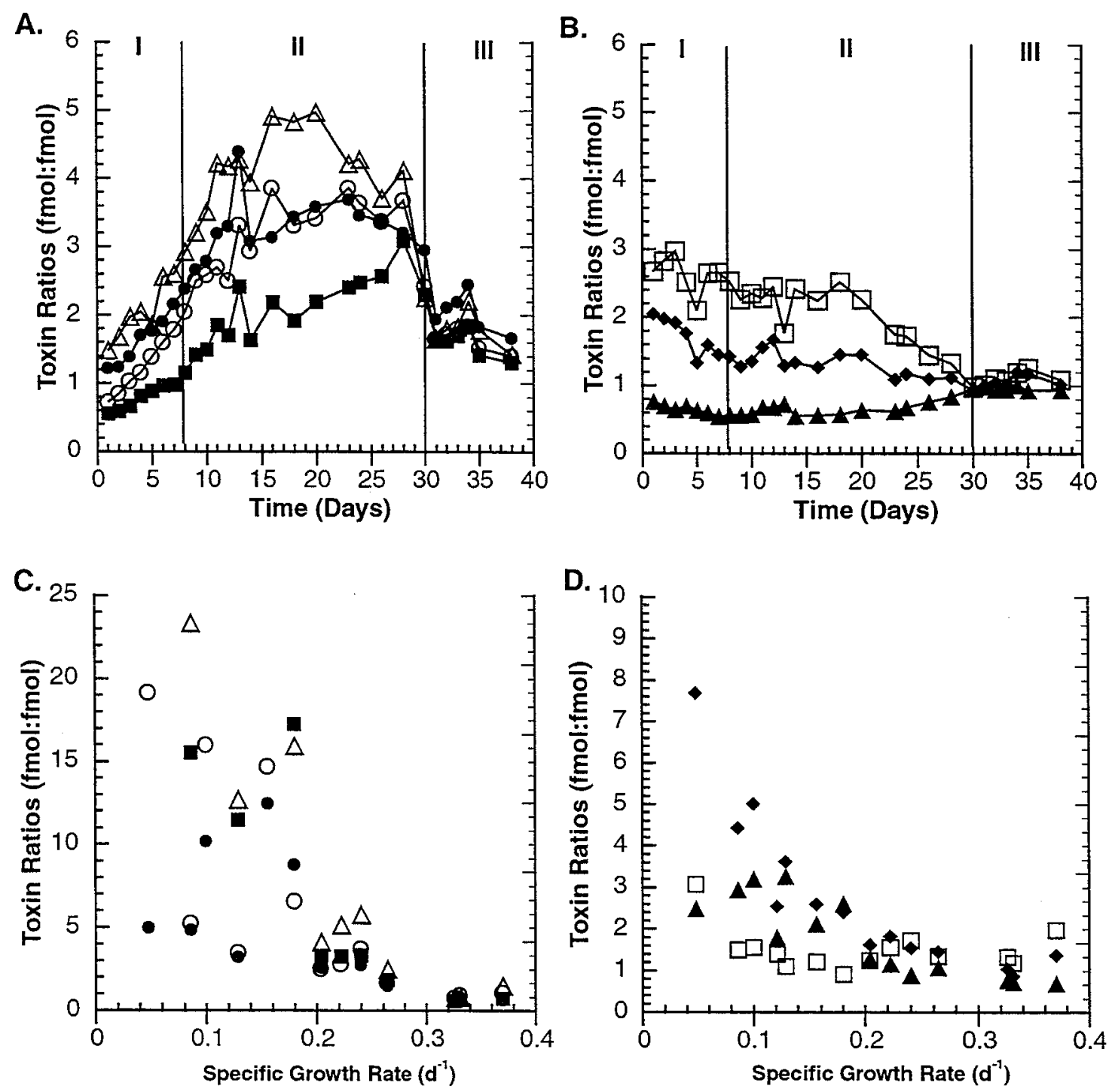
Nitrate Starvation and Nitrate Uptake Rates. Chl a profiles in the mesocosm experiments showed that $A$. fundyense (strain 38-3) from Casco Bay, Maine does not migrate vertically to $\mathrm{N}$-rich deep layers in response to nutrient limitation in the surface layer. This finding contradicts observations of MacIntyre et al. (1997), who showed that $A$. tamarense migrated (via DVM) to deep $\mathrm{N}$ pools following decreased $\mathrm{N}$ concentrations in the surface layer of the mesocosm. The contrast could be due to behavioral or physiological differences or both. Therefore, to better understand differences between these mesocosm experiments, we monitored three strains of Alexandrium fundyense(including 38-3) in batch cultures grown at $17^{\circ} \mathrm{C}$ and ca. $200 \mu \mathrm{mol}$ quanta $\mathrm{m}^{-2} \mathrm{~s}^{-1}$ (conditions similar to the first mesocosm experiment). Our objective is to describe and understand how unbalanced growth and nitrate starvation affect the biochemical status of the cell and whether different Casco Bay strains have the ability to acquire nitrate in the dark.

The three A. fundyense isolates from Casco Bay grew at similar cell specific growth rates during the batch culture experiments, calculated using the following equation:

$$
\mu=\frac{\ln \left(N_{5} / N_{2}\right)}{t_{5}-t_{2}}
$$

where $N_{\mathrm{t}}$ is the concentration at time $t$. The subscripts denote values at two times. The cell specific growth rates for each Casco Bay isolate were calculated over a period of 3 days, Day 2 to Day 5 that denotes the period of exponential growth prior to nitrate starvation (before Day 6). The three isolates 38-3, CB-307, and CB-501 grew at rates of 0.36 $\mathrm{d}^{-1}, 0.34 \mathrm{~d}^{-1}$, and $0.34 \mathrm{~d}^{-1}$, respectively. The three batch culture experiments were divided 
into two phases that define different levels of nitrate-availability: Phase I, N-replete, (Days 0-4) and Phase II, N-deplete, (Days 5-8). The initial nitrate concentrations in all three flasks averaged $55 \pm 2.5 \mu \mathrm{M}$ and decreased steadily until nitrate was depleted by the beginning of Day 5 (Figure 3.8. A). After nitrate depletion occurred in all batch culture flasks, chl $a$ decreased by $0.08 \mathrm{~d}^{-1}$ as cell division continued and chl $a$ synthesis decreased (Figure $3.8 \mathrm{~B}$ ). Overall, total chl $a$ concentrations increased steadily through Phase I then decreased gradually through Phase II (Figure $3.8 \mathrm{C}$ ).

Over the course of the batch culture experiment the cell physiology changed dramatically as the nitrate availability decreased. During Phase I, chl $a$ per cell was $50 \pm 2$ pg at the beginning of the experiment and increased slowly to $70 \pm 2$ pg cell $^{-1}$ by Day 5 (Figure 3.9 A). However, once nitrate starvation began, the chl $a$ per cell rapidly decreased to approximately $25 \pm 2 \mathrm{pg}$ cell $^{-1}$, similar to chl $a$ values that appeared after Ndepletion in the surface layer of mesocosm experiments. The $\mathrm{C}: \mathrm{N}$ ratio increased from an initial value of $6 \pm 1$ to $13 \pm 1 \mathrm{~mol} \mathrm{~mol}^{-1}$ by Day 7 (Figure $3.9 \mathrm{~B}$ ). Prior to nitrate depletion, the CHO: chl a ratio was very low (10-30), but after Day 5 the ratio increased to a value between $140-180$ (Figure $3.9 \mathrm{C}$ ). This large increase in the $\mathrm{CHO}$ :chl a ratio was not observed during the first mesocosm experiment. Overall, the changes observed in the batch cultures were nearly identical in all 3 strains of Alexandrium examined.

In order for assimilation of deep nutrients to occur (via DVM) these strains must have the ability to acquire nitrate (nitrogen) at night (Eppley and Harrison 1975; Cullen 1985). Without dark nitrate acquisition the adaptive advantages of DVM, such as increased cellular growth rate, would not occur and the cells would remain N-limited in the surface 
FIGURE 3.8. Changes in (A) nitrate concentration $(\mu \mathrm{M})$, (B) cell concentration, (C) total chl $a\left(\mu \mathrm{g}^{-1}\right)$, during $\mathrm{N}$-starved batch culture for three strains of Alexandrium fundyense from Casco Bay, Maine; strain 38-3 (đ), strain CB-501 (A), strain CB-307 (O). Error bars for cell concentration, total chl $a$, and nitrate are mean $\pm \mathrm{SD}(\mathrm{n}=2,3$ \& 2 , respectively). The two phases of the experiment are labeled and delimited by one vertical line. 


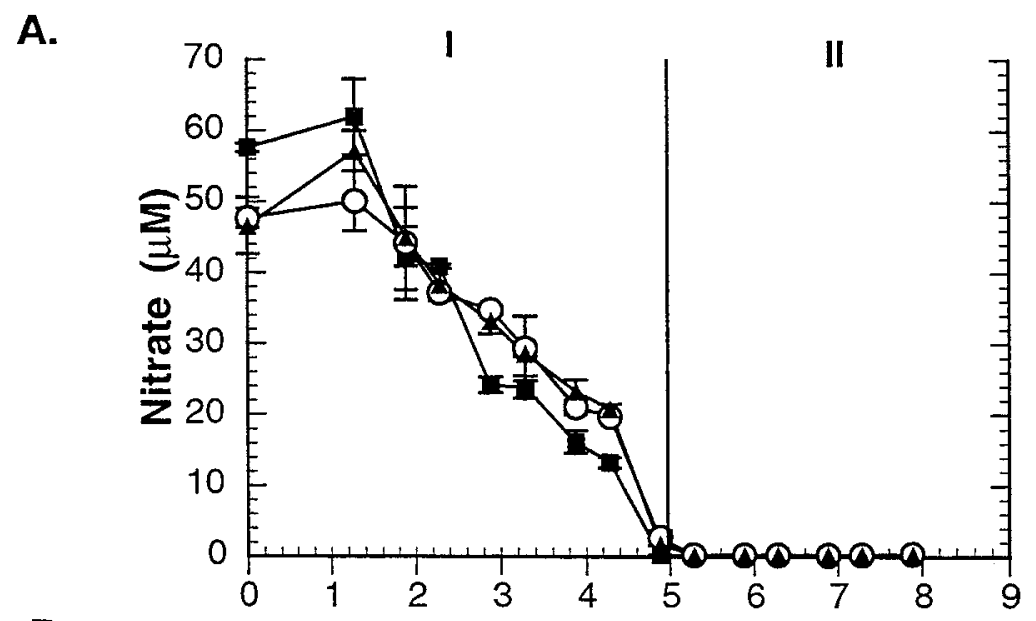

B.
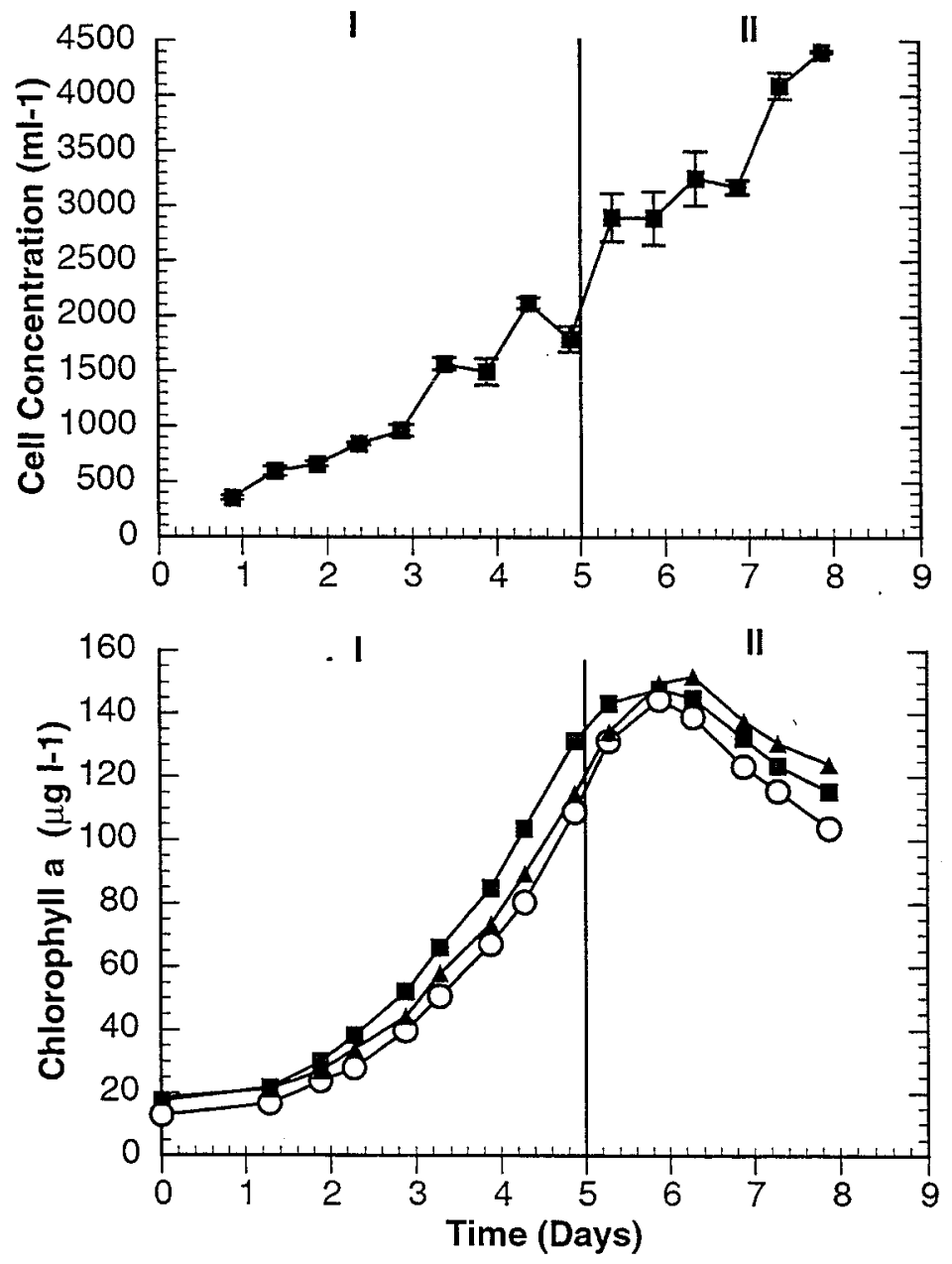
FIGURE 3.9. Changes in the cellular nitrogen status during batch growth for three strains of Alexandrium fundyense (see Figure 3.6 for symbols) (A) $\mathrm{chl} a\left(\mathrm{pg} \mathrm{chl} \mathrm{cell}^{-1}\right.$ ), (B) C:N, (C) CHO:chl $a$ ratio. Samples for C:N and carbohydrates determined at 09:00 and 21:00 daily, beginning on Day 4. Error bars for $\mathrm{chl} a$ and C:N are mean \pm SE (n=3). 
A.

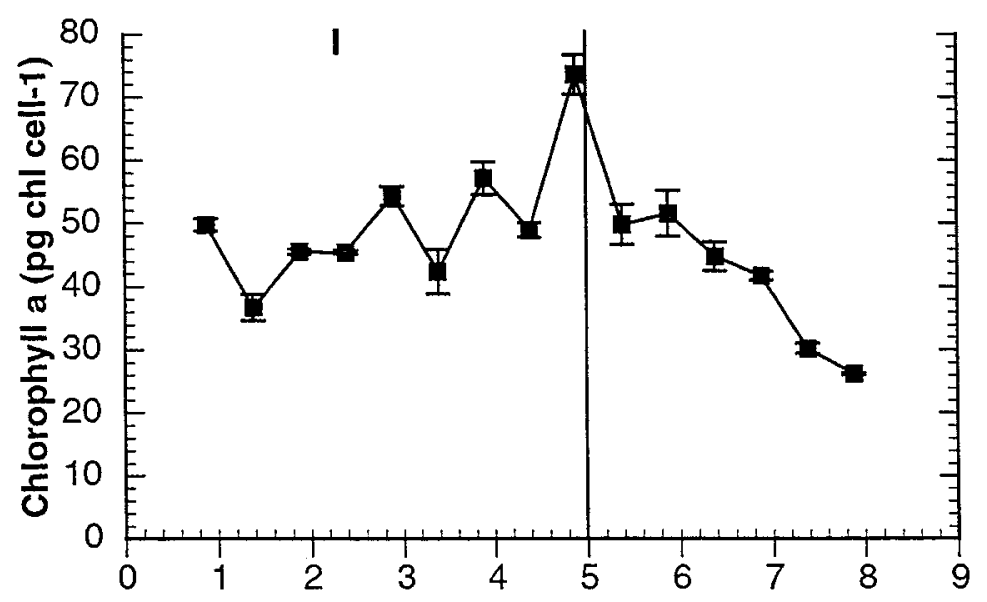

B.

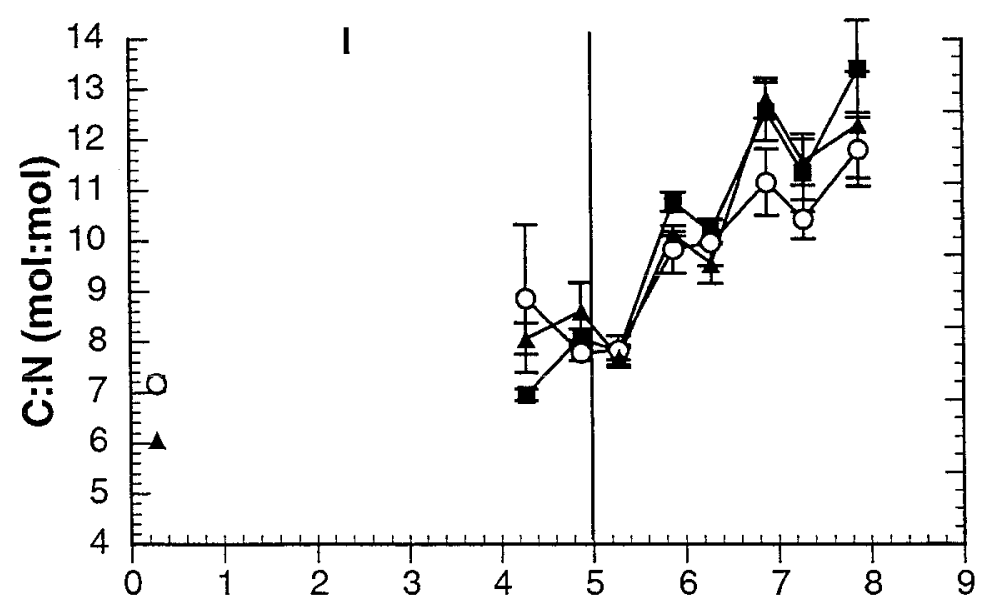

c.

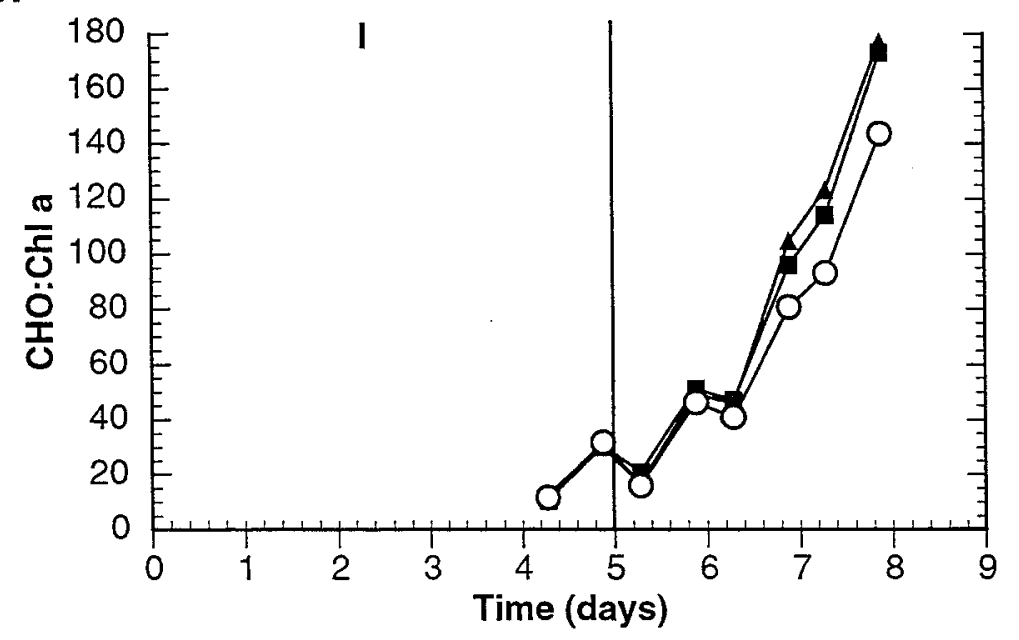


layer and would not utilize the available $\mathrm{N}$ at the lower portion of the mesocosm. Therefore, nitrate uptake rates were calculated during both the light and dark period before and after nitrate starvation. For all three cultures, the uptake rates (normalized to cell chl $a$ ) prior to nitrate starvation were high during the light period and low at night. However, once starvation was induced the dark uptakes rates increased, nearly tripling the dark uptake rates prior to $\mathrm{N}$-stress (Figure 3.10 A). Simultaneously, total carbohydrate concentrations in the cultures increased dramatically once Phase II began. However, when nitrate was resupplied at night, during the dark nitrate uptake experiments, rapid decreases in the total carbohydrate concentration and $\mathrm{C}: \mathrm{N}$ ratio were observed as nitrogen was assimilated (Figure 3.10 B \& C). This change in carbon utilization at night was observed in all three strains of Alexandrium.

FIGURE 3.10. Alexandrium fundyense, strain 38-3 before (Phase I) and after (Phase II) $\mathrm{N}$-starvation. (A) Rates of light and dark nitrate uptake during batch growth pre- and post- nitrate starvation, total nitrate $(\mu \mathrm{M})(\boldsymbol{\square})$ in the flask is superimposed over nitrate uptake rates. Error bars are mean $\pm \mathrm{SD}(\mathrm{n}=2)$. (B) total carbohydrate $\left(\mu \mathrm{g} \mathrm{ml^{-1 }}\right)(\mathrm{O})$, total nitrate $(\mu \mathrm{M})(\mathbf{\square})$ and carbohydrate concentration from cultured sub-samples after a dark incubation nitrate spike (A). (C) $\mathrm{C}: \mathrm{N}(\mathrm{mol}: \mathrm{mol})(\mathrm{O})$, total nitrate $(\mu \mathrm{M})(\boldsymbol{\square})$, and $\mathrm{C}: \mathrm{N}$ of the cells from cultured sub-samples after a dark incubation nitrate spike $(\mathbf{A})$. The two phases of the experiment are labeled and delimited by one vertical line. Error bars for carbohydrate, total nitrate, and $\mathrm{C}: \mathrm{N}$ are mean $\pm \mathrm{SD}(\mathrm{n}=2)$. 
A.

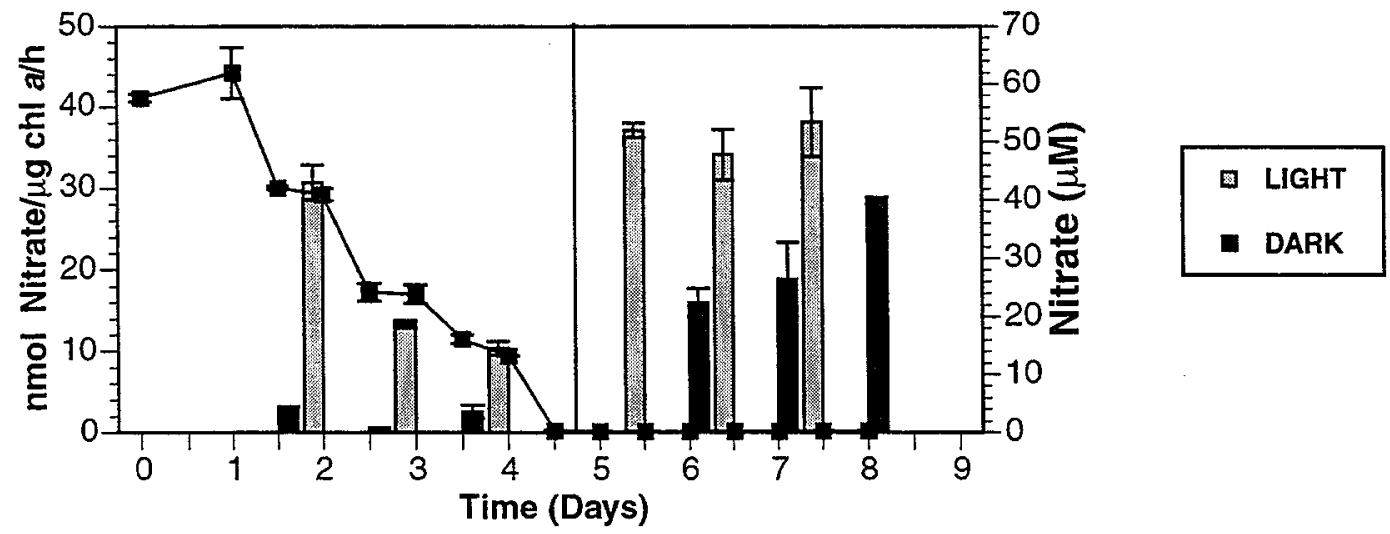

B.

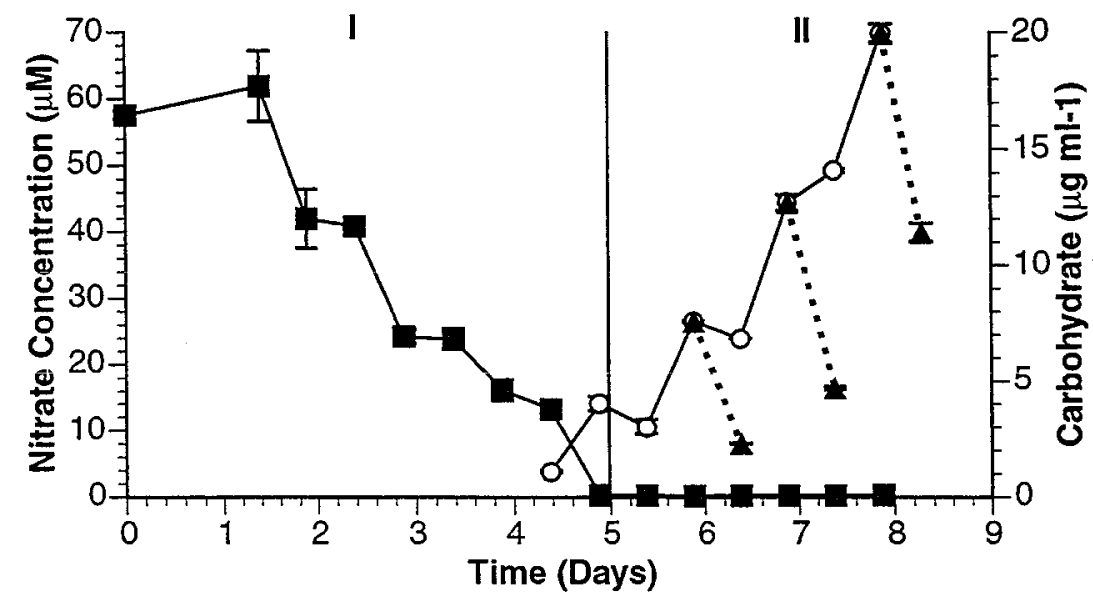

c.

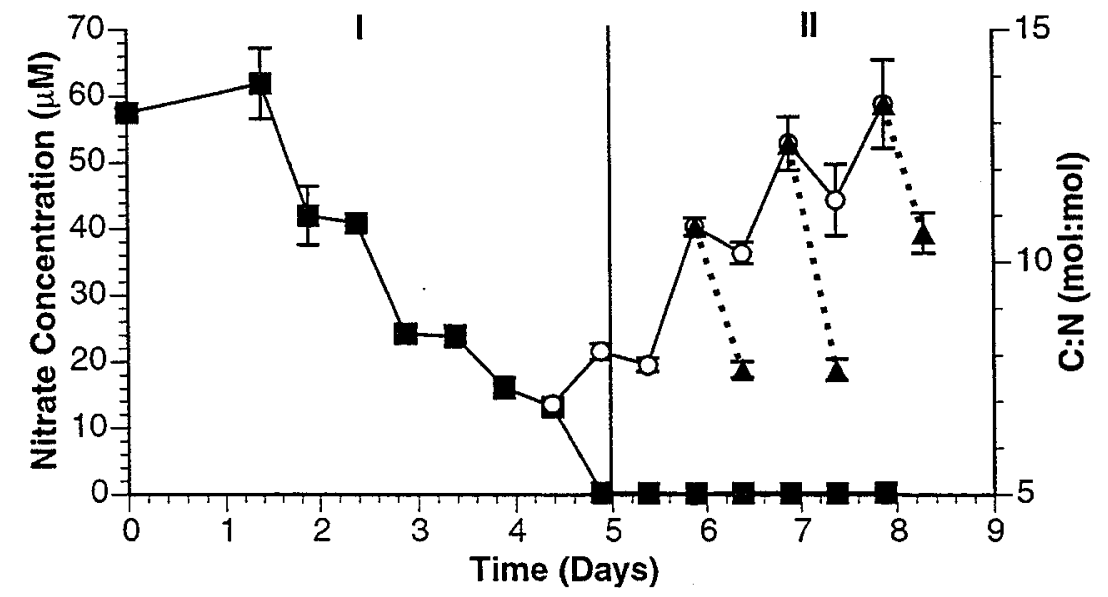


Nitrate Limitation during Balanced Growth. As observed during Phase I of the first mesocosm experiment (Days 3-7) and during Phase II of the batch culture experiments, unbalanced growth during $\mathrm{N}$-starvation caused rapid changes in the intracellular biochemical composition. However, during Phase II of the first mesocosm, $\mathrm{N}$-availability was very low in the surface layer and the quantities of biochemical cellular constituents began to stabilize as would occur during $\mathrm{N}$-acclimated steady-state. In order to identify indicators of N-status of Alexandrium in culture or field populations, we needed to determine the physiological differences between unbalanced ( $\mathrm{N}$-starved) and balanced $(\mathrm{N}$ acclimated) growth. Therefore, we designed an experiment that measured three nitrogen nutritional states, $\mathrm{N}$-replete, $\mathrm{N}$-starved and $\mathrm{N}$-acclimated growth, consecutively, to compare and contrast the intracellular changes that occur during each nutritional condition and ultimately compare these results to the initial mesocosm and batch culture experiments.

Initially, four flasks of A. fundyense (strain 38-3) were grown in batch culture at an average cellular-specific growth rate of $0.35 \mathrm{~d}^{-1}$ (as determined using the growth equation described previously). Once the nitrate in all four flasks was depleted by Day 6, two nitrate limiting dilution rates, $30 \%$ and $15 \% \mathrm{~d}^{-1}$, were begun (diluting twice per day). The cellular-specific growth rates for these semi-continuous cultures were determined using the exponential growth equation as described by MacIntyre et al. (1997):

$$
\mu_{t}=\frac{1}{\Delta t}\left(\ln \frac{N_{t} /(1-D)}{N_{t-\Delta t}}\right)
$$


where $N_{\mathrm{t}}$ is the cell density (cells ml-1) at time t (d), $N_{\mathrm{t}-\mathrm{t}}$ is the cell density (cells ml ${ }^{-1}$ ) at a previous time (here $\Delta \mathrm{t}$ is either $10 / 24 \mathrm{~h}$ or $14 / 24 \mathrm{~h}$ depending on whether $\mu$ is calculated for the light or dark period) and $D$ is the dilution rate (volume of medium added/total volume). After Day 16 the flasks diluted $30 \% \mathrm{~d}^{-1}$ grew at average rates of $\sim 0.28$ to $\sim 0.30$ $\mathrm{d}^{-1}$, while the flasks diluted $15 \% \mathrm{~d}^{-1}$ grew at average rates of $\sim 0.13$ to $\sim 0.14 \mathrm{~d}^{-1}$.

For the first seven days, the internal biochemical changes that occurred were similar to the batch culture $\mathrm{N}$-starvation experiment until the dilutions were begun and steady state was maintained. As observed during batch growth, the cell density and total chl $a$ rapidly increase (Figure 3.11 A \& B). Similar to the previous experiments this experiment was divided into 3 different phases of $\mathrm{N}$-availability: Phase I, N-replete (Day 04); Phase II, N-starved (Day 5-15); and Phase III, N-acclimated (Day 16-42). During the beginning of Phase I the average chl $a$ per cell, CHO:chl $a$, and C:N were approximately $63 \pm 3$ pg cell ${ }^{-1}, 15.9 \pm 0.7$, and $7.5 \pm 0.8$, respectively (Figure 3.12 ). The $F_{v} / F_{m}$ was initially high at 0.7 ; however, it begins to decrease as nitrate was utilized in the cultures (Figure $3.11 \mathrm{C}$ ). At the beginning of Phase II nitrate was depleted from all the flasks and cells entered a brief period of N-starvation. During Phase II chl $a$ per cell decreased dramatically to $21 \pm 5 \mathrm{pg} \mathrm{cell}^{-1}$, whereas the CHO:chl $a$ and C:N ratios increase rapidly (Figure 3.12). The $F_{v} / F_{m}$ decreased to an average minimum of $0.49 \pm 0.03$, but once the dilutions commenced during Phase II values increased gradually to an average value of $0.65 \pm 0.03$ after Day 25. It was apparent that by the beginning of Phase III ( Day 17) the cells had acclimated to two different levels of nitrate limitation (Figures $3.11 \& 3.12$ ). The flasks diluted $30 \% \mathrm{~d}^{-1}$ 
FIGURE 3.11. Alexandrium fundyense, strain 38-3. Characteristics of semi-continuous culture. (A) cell concentration, $30 \% \mathrm{~d}^{-1}\left(\& \mathbb{\square}\right.$; replicate flasks); $15 \% \mathrm{~d}^{-1}(\mathrm{O} \& \square)$, mean $\pm \mathrm{SD}, \mathrm{n}=2$. (B) $\operatorname{chl} a\left(\mu \mathrm{g} \mathrm{L}^{-1}\right)$ - see symbols from A. (C) $\mathrm{F}_{\mathrm{v}} / \mathrm{F}_{\mathrm{m}}, 30 \% \mathrm{~d}^{-1}(\mathbf{a}) ; 15 \% \mathrm{~d}^{-1}(\mathrm{O})$. The three phases of the experiment are labeled and delimited by vertical lines. The dashed line represents when dilutions commenced. Error bars for chl $a$ and $\mathrm{F}_{\mathrm{v}} / \mathrm{F}_{\mathrm{m}}$ are mean $\pm S E, n=3$. 

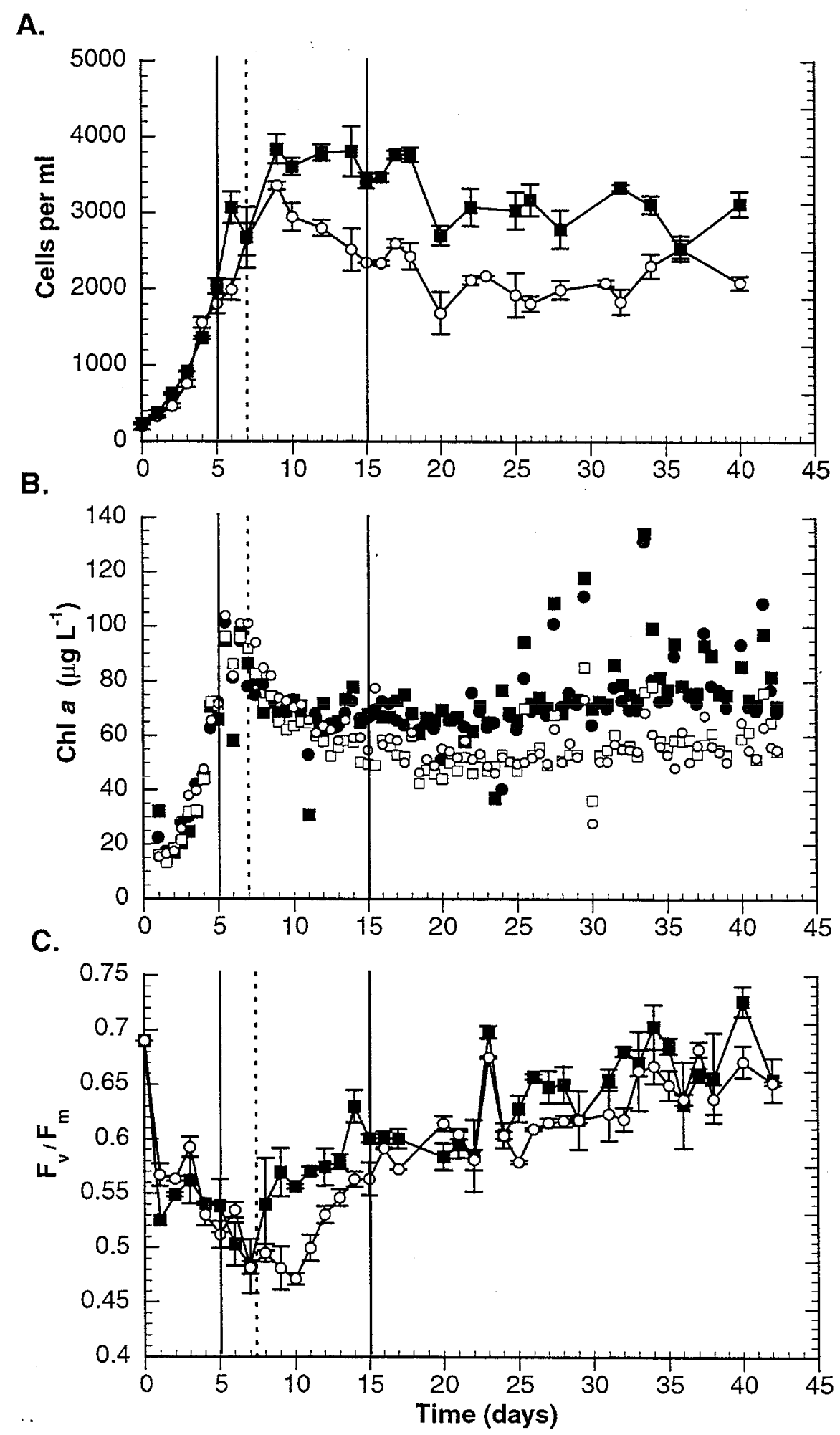
FIGURE 3.12. Alexandrium fundyense, strain $38-3$. Physiological characteristics during N-limited semi-continuous culture. (A) C:N (mol:mol), (B) CHO:chl $a$ ratio, (C) $\mathrm{Chl} a$ $\left(\mathrm{pg} \operatorname{cell}^{-1}\right)$. 
A.

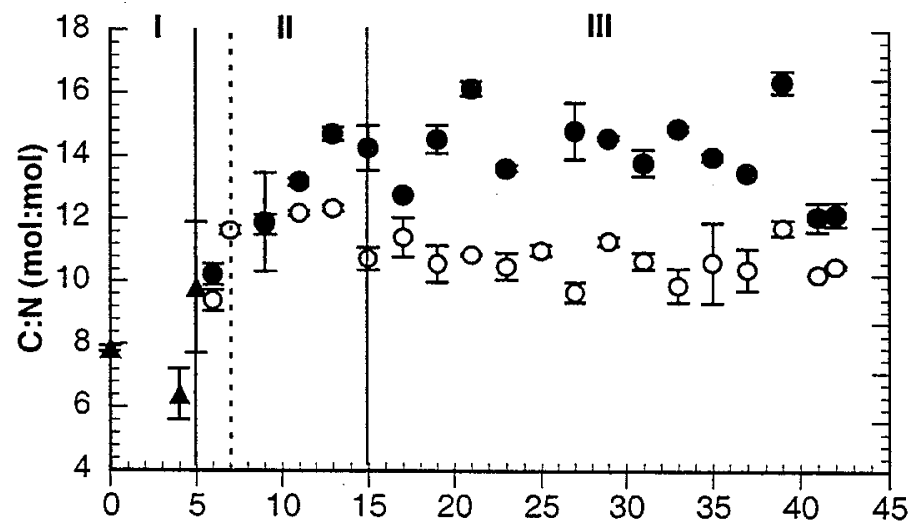

B.

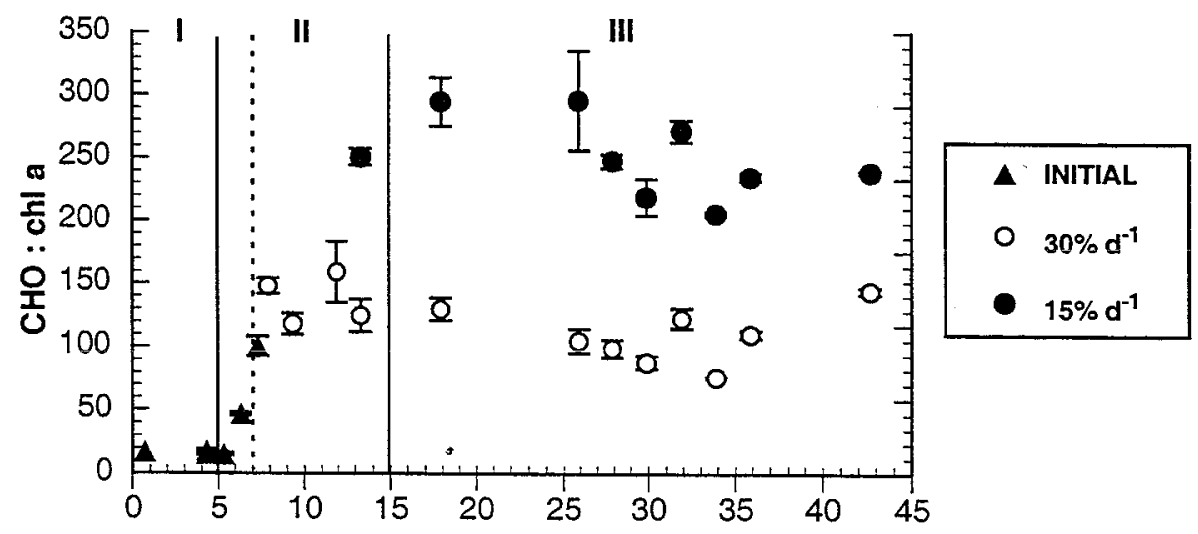

c.

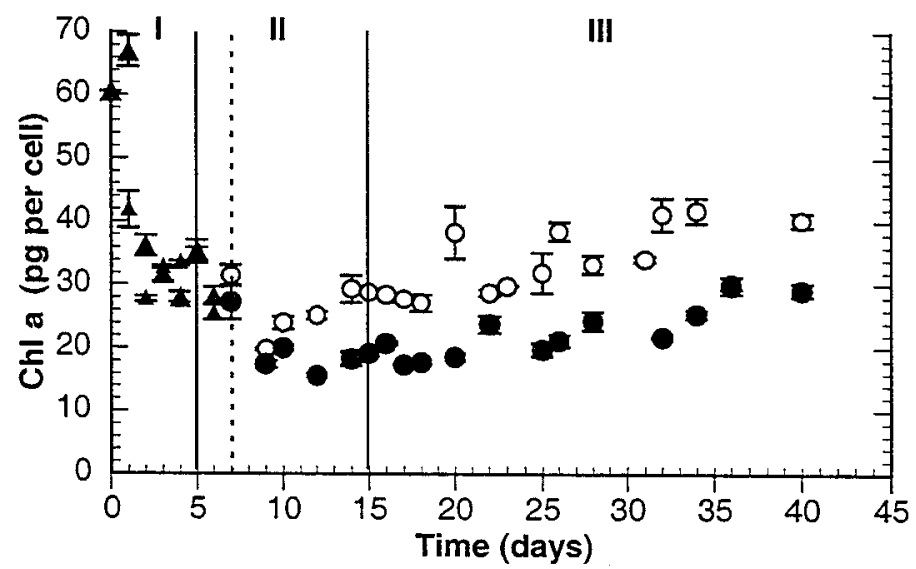


had an average cell density of $2200 \pm 300$ cells ml $^{-1}$ and an average total chl $a$ of $55 \pm 5$ $\mu \mathrm{g} \mathrm{L}{ }^{-1}$; however, the flasks diluted at $15 \% \mathrm{~d}^{-1}$ had an average cell density of $3200 \pm 300$ cells ml${ }^{-1}$ and an average total chl $a$ of $75 \pm 9 \mu \mathrm{L} \mathrm{L}^{-1}$. The values obtained from flasks diluted $15 \% \mathrm{~d}^{-1}$ were similar to nutrient limited values obtained by MacIntyre et al. (1997) during N-limited semi-continuous culture of A.tamarense. During this study, for the flasks diluted $30 \% \mathrm{~d}^{-1}$, the chl $a$, CHO:chl $a$ and C:N stabilized at $33 \pm 3$ pg cell $^{-1}, 110$ $\pm 20 \%$, and $11 \pm 5 \%$, respectively. At $15 \% \mathrm{~d}^{-1}$ the chl $a$, CHO:chl $a$ and C:N were $22 \pm 2$ pg cell ${ }^{-1}, 250 \pm 13 \%$, and $14 \pm 9 \%$, respectively.

For both nitrate-limited, semi-continuous cultures the residual nitrate values ranged between $0-2 \mu \mathrm{M}$ (Figure 3.13). The nitrate concentrations measured after nitrate addition at either the beginning of the light or dark period for the $30 \%$ and $15 \% \mathrm{~d}^{-1}$ dilutions ranged between 6.5-8.5 $\mu \mathrm{M}$ and 3.3 and $5.2 \mu \mathrm{M} \mathrm{NO}_{3}{ }^{-}$, respectively. Nitrate uptake rates were calculated based on 12 hour averages (light cycle and dark cycle) throughout the semi-continuous experiments using the equation described on page 98. During Nreplete conditions (Phase I), the light uptake rates in all four flasks were as high as $0.03 \pm$ $0.01 \mu \mathrm{mol} \mathrm{NO}_{3} / / \mu \mathrm{mol} \mathrm{N} / \mathrm{h}$ which could account of growth, while dark nitrate uptake rates were low and averaged $0.005 \pm 0.001 \mu \mathrm{mol} \mathrm{NO}{ }_{3} \% \mu \mathrm{mol} \mathrm{N} / \mathrm{h}$. However, once the cells were $\mathrm{N}$-starved and dilutions began both the light and dark nitrate uptake rates were high, averaging $0.09 \pm 0.01 \mu \mathrm{mol} \mathrm{NO}_{3} / / \mu \mathrm{mol} \mathrm{N} / \mathrm{h}$ for the light period and $0.08 \pm 0.01 \mu \mathrm{mol}$ $\mathrm{NO}_{3}{ }^{-} / \mu \mathrm{mol} \mathrm{N} / \mathrm{h}$ for the dark period, both of which were sufficient and could account for growth during both the light and dark period. 


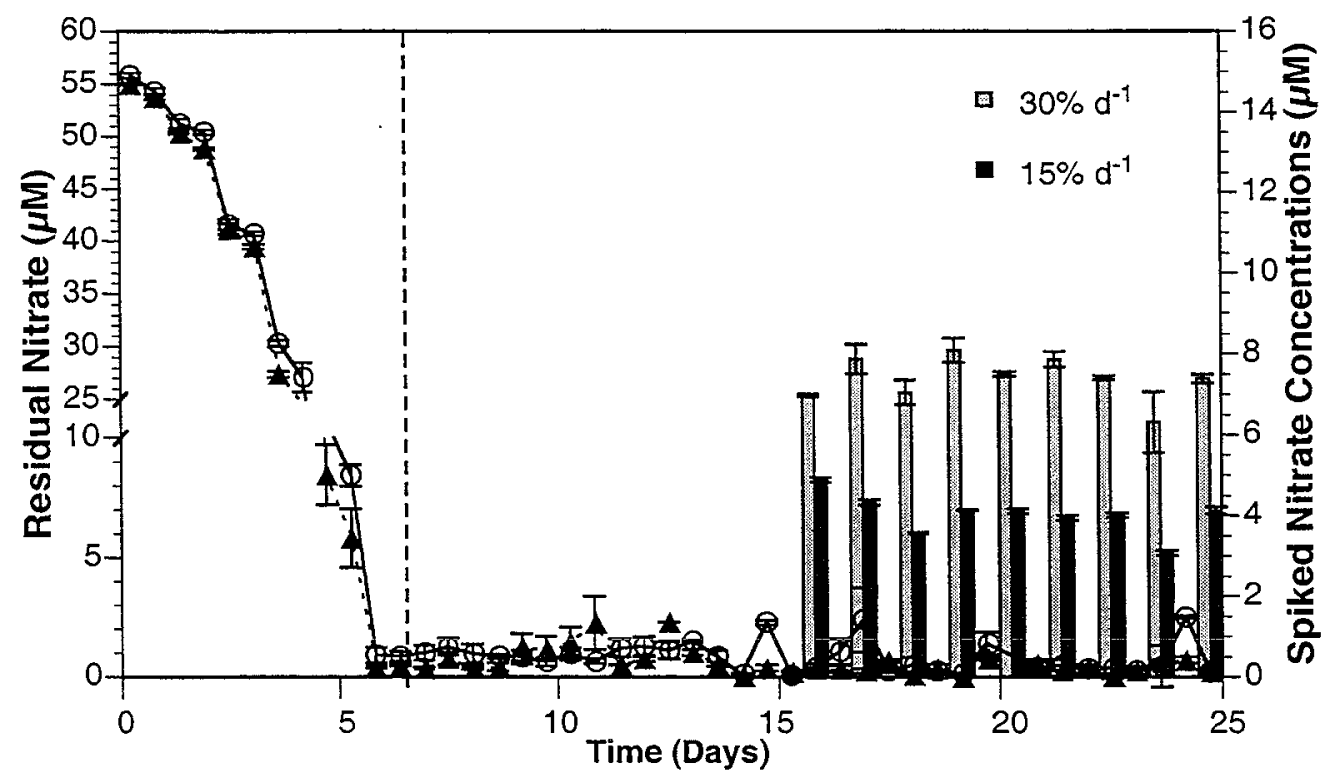

FIGURE 3.13. Alexandrium fundyense strain $38-3$, N-limited semi-continuous nitrate concentrations and nitrate residuals for flasks diluted $30 \% \mathrm{~d}^{-1}(\mathbf{\Delta}) \& 15 \% \mathrm{~d}^{-1}(\mathrm{O})$. The grey and black columns represent the nitrate concentrations immediately after nitrate addition (dilution) that occurred at the beginning of the light and dark periods for flasks diluted $30 \% \mathrm{~d}^{-1}$ (grey bars) and flasks diluted $15 \% \mathrm{~d}^{-1}$ (black bars). The dashed line marks the beginning of the semi-continuous $\mathrm{N}$-limited dilutions. 


\section{DISCUSSION}

In order to study and interpret bloom dynamics of harmful algal species, such as Alexandrium, it is necessary to understand how these species adapt and persist during changing chemical, temporal, and hydrographic conditions (Anderson 1997; Cullen and MacIntyre 1998). In particular, nutrient concentrations associated with Alexandrium blooms in the Western Gulf of Maine - specifically nitrogen - can be very low; $(<2 \mu \mathrm{M}$ DIN) (Martorano 1997) and could be potentially limiting for growth of Alexandrium in the field. In turn the physical environment, for example sea surface temperature, riverine inputs and wind forcings, also may be a potential factor in regulating the distribution and abundance of Alexandrium spp (Franks et al. 1992). In addition, small-scale turbulence or circulation can also directly effect a cell's vertical progress (vertical migration) in the environment due to cell dispersion, disorientation and possible loss of flagella (Kamykowski 1995). By interpreting and defining indicators or diagnostics of nutrient status we can begin to understand how nutrients regulate bloom longevity and termination. In this study, we attempt to elucidate intracellular physiological indicators and behavioral adaptations to changes in nitrogen (nitrate) availability, using mesocosms and laboratory cultures grown under different nitrogen conditions. We identify diagnostics of three different nitrogen nutritional states: $\mathrm{N}$-replete, $\mathrm{N}$-starved and $\mathrm{N}$-acclimated - based on the photosynthetic efficiency $\left(F_{v} / F_{m}\right)$, intracellular chemical responses, and changes in the toxin content and composition. 
Behavioral observations. To date Alexandrium species have exhibited migration behavior across steep pycnoclines (Rasmussen and Richardson 1989), temperature (Santos and Carreto 1992) and nutrient (MacIntyre et al. 1997) gradients, and for decades the influence of $\mathrm{N}$-nutrition has been associated with migration patterns for many dinoflagellates in both the laboratory and the field (Eppley and Harrison 1975; Blasco 1978; Cullen and Horrigan 1981; Kamykowski et al. 1998; Kamykowski et al. 1999). During a study by MacIntyre et al. (1997), Alexandrium tamarense from the Gulf of St. Lawrence was capable of migrating across thermoclines in order to exploit deep nitrogen pools when induced by low $\mathrm{N}$ concentration in surface waters. In this study, however, changes in the ambient $\mathrm{N}$-status did not induce vertical migration behavior for an isolate of $A$. fundyense from Casco Bay, Maine. There was a pronounced phototactic response as the cells aggregated to within the top $1 \mathrm{~cm}$ of the water column during the light period, and $A$. fundyense was undetected using fluorescence profiles below $60 \mathrm{~cm}$, even after nitrate was depleted in the surface layer. The non-migrating behavior of this $A$. fundyense strain was unaffected by increases in temperature (above and below the thermocline; Figure 3.1) during the first mesocosm experiment or by changes in the surface irradiance from 350 $800 \mu \mathrm{mol} \mathrm{q} \mathrm{m} \mathrm{m}^{-2} \mathrm{~s}^{-1}$ (Figure 3.2).

The lack of vertical migration after nitrate depletion in the surface layer was unexpected based on previous studies using A.tamarense in the same mesocosm (MacIntyre et al. 1997). To determine why this $A$. fundyense strain did not migrate. I first verified that the $\mathrm{N}$-rich medium $(\sim 40 \mu \mathrm{M}$ nitrate) below the thermocline could sustain growth, as observed in subsamples removed from the deeper strata of the mesocosm and 
inoculated with $A$. fundyense cells from the surface layer. In order for this strain to exploit nitrate from below the thermocline, the cells require the ability to acquire nitrogen in very low light or the dark (Cullen and MacIntyre 199.8). Therefore, light and dark nitrogen uptake rates of $A$. fundyense were measured within the first mesocosm experiment and subsequent laboratory experiments. I hypothesize that if the cells were unable to acquire nitrogen in the dark, they would not have migrated within the mesocosm and would not have utilized the nitrate available below the thermocline.

Initially, the lack of nitrogen acquisition in the dark (after Day 28 in the first mesocosm experiment) was thought to have prevented the cells from migrating to deep nitrogen pools; however, dark nitrate uptake was induced after N-depletion occurred in both nitrate limited batch and semi-continuous cultures (e.g. Figure 3.8). The increase in carbohydrate concentrations during the $\mathrm{N}$-starved batch culture experiments is indicative of N-depletion. When nitrogen assimilation ceases, photosynthate (carbohydrates/carbon skeletons) produced during the light period is not mobilized at night or in the dark causing the C:N and total carbohydrate concentration to increase (Cuhel et al. 1984; Cullen 1985). However, when nitrate was resupplied at night during the nitrate uptake experiments (simulating migration to deep nitrogen pools), decreases in total carbohydrate and $\mathrm{C}: \mathrm{N}$ (Figure $3.8 \mathrm{~B} \& \mathrm{C}$ ) were due to the remobilization of photosynthate to assimilate nitrogen. The storage of photosynthate during the day and utilization at night during Nassimilation has been proposed as a biochemical mechanism (source-sink regulation) that provides the resources necessary to support DVM (Cullen 1985). All the Casco Bay isolates examined (38-3, CB-307 and CB-501) were able to utilize this mechanism of 
source-sink regulation to assimilate nitrogen and sustain growth in the dark, but in the isolate for which behavioral observations were made (strain 38-3) no vertical migration occurred as nitrogen availability decreased.

The contrasting responses in behavior to N-stress between the Gulf of St. Lawrence $A$. tamarense and Casco Bay A. fundyense isolates may be due to genetic differences (such as differential gene expression) or an unknown physiological factor that was not considered in this study, for example, another type of limitation may have occurred. Also, very little is understood about the effect of light and nutrients on the physiology of the cell that consequently affects cellular orientation and migration behavior (Kamykowski 1995, Kamykowski et al. 1999). It has been suggested that the locations of intracellular constituents such as storage compounds (lipids and carbohydrates) and other organelles (chloroplasts and nucleus) may relate to orientation patterns, but further study is required (Kamykowski et al. 1998). Genetically based behavioral differences between the two Alexandrium species could be associated with geographical or regional isolation. It may be that the physical and chemical processes associated with the two regions vary sufficiently to naturally select cells that behave in a manner that optimizes growth, survival, and cyst production within that region.

Cellular physiology. Cellular chemical composition of phytoplankton is very sensitive to environmental factors, such as, light, temperature and available nutrients. Here, I focus on the effects of nutrients, specifically nitrate, and how $A$. fundyense adapts to different conditions of N-availability. The internal responses observed were consistent with the 
changes in the allocation of photosynthate (cellular carbon) between three intracellular pools (Shuter 1979; Geider et al. 1996; Geider et al. 1997; Geider et al. 1998). These pools are defined as the light harvesting apparatus ( $\mathrm{chl} a$ ), biosynthetic apparatus (enzymes and protein synthesis), and storage reserves (carbon skeletons, carbohydrates and lipids). Acclimation to different nutrient conditions, irradiance and temperature gradients is achieved through unbalanced growth, that is when different cellular components are synthesized at different rates (Shuter 1979; Cullen and MacIntyre 1998). For example, during high irradiance, low temperatures and low ambient nutrient concentrations, the ability to harvest light decreases causing either a decrease in chl $a$ or an increase in storage reserves, ultimately causing the $\mathrm{C}: \mathrm{chl} a$ ratio to increase. These changes due to external conditions can be described by modifications in the ratio of light absorption to light utilization (Geider et al. 1996).

Physiological limitations can also be resolved by assessing the variability in phytoplankton photosynthetic parameters by active fluorescence techniques (Falkowski et al. 1992). The maximum change in quantum yield of fluorescence or photosynthetic efficiency $\left(\mathrm{F}_{\mathrm{v}} / \mathrm{F}_{\mathrm{m}}\right)$ can be measured by fluorescent induction using a photosynthetic inhibitor (i.e. DCMU) or pump and probe fluorometer, such as a fast repetition rate flurometer (FRR) or a pulse amplitude modulated (PAM) fluorometer. DCMU in particular, inhibits photosynthesis by blocking the electron transport chain, therefore, the plastoquinone pool cannot be reoxidized and the in vivo fluorescence increases. The enhanced fluorescence (or variable fluorescence, $F_{v}=F_{o}-F_{m}$ ) is related to the amount of energy that would be used for PSII photochemistry (Falkowski and Kiefer 1985). Decreases in this ratio have 
been associated with different limiting nutrients in phytoplankton specifically, $\mathrm{Fe}$ deficient (Greene et al. 1991) as well as nitrate-deficient phytoplankton (Cleveland and Perry 1987; Kolber et al. 1988). Given these intracellular adaptations to different environmental conditions I attempted to identify physiological characteristics or diagnostics of different nitrogen nutritional states of Alexandrium, such as, $\mathrm{N}$-starved, $\mathrm{N}$-acclimated, and $\mathrm{N}$-replete conditions.

Allocation of Carbon and Nitrogen. During N-starvation in all three experiments (summarized in Table 3.1), growth was unbalanced because $\mathrm{N}$-assimilation decreased or ceased and the synthesis of proteins and enzymes was reduced. Therefore, the capacity to synthesize light harvesting proteins decreased, causing a decline in $\operatorname{chl} a$ and photosynthesis. In turn, as photosynthesis continued the photosynthate (the carbon skeletons required for protein synthesis) was stored and could be utilized once $\mathrm{N}$ was available. This caused a rapid increase in the overall $\mathrm{C}: \mathrm{Chl}$ a ratio, and $\mathrm{C}: \mathrm{N}$, and a decrease in the overall cellular chl $a$ content as observed during Phase I of the first mesocosm and Phase II of the batch and semi-continuous experiments (Figures 3.3, 3.4, 3.9, \& 3.12). The $\mathrm{F}_{\sqrt{ }} / \mathrm{F}_{\mathrm{m}} \mathrm{ra}-$ tio also decreased rapidly as the inactivation of PSII reaction centers occurred due to the inability of the cell to produce key proteins for efficient energy transfer within the photosystems (Figures $3.3 \& 3.11 \mathrm{C}$ ). These rapid decreases in photosynthetic quantum yield and pigment content during $\mathrm{N}$-starvation have also been observed in batch cultures of Chaetoceros gracilis and Thalassiosira pseudonana (Welschmeyer and Lorenzen 1981; Cleveland and Perry 1987). Studies by Anderson et al. (1990) and MacIntyre et al. (1997) 
that examined modifications in toxin content during $\mathrm{N}$-starvation for Alexandrium sp. also showed similar changes in chl $a$, particulate $\mathrm{C}$ and $\mathrm{N}$, and $\mathrm{F}_{\mathrm{v}} / \mathrm{F}_{\mathrm{m}}$.

The results obtained during $\mathrm{N}$-starvation during both the mesocosm and batch culture experiments were significantly different from those obtained during nitrateacclimated semi-continuous culture. During $\mathrm{N}$-acclimated growth, concentrations of different compounds that require nitrate decrease (e.g. chl $a$ ) and storage products (photosynthate) increase until the amounts of cellular constituents increase at the same nutrientlimited rate (averaged over the photo-period as described previously) (Eppley 1981; Cullen et al. 1985; Cullen et al. 1992; Geider et al. 1997). Therefore, the growth rate that determines the amount of algal carbon produced is reduced to match the growth rate allowed by the nutrient supply (Bannister and Laws 1980). This rate stabilization occurred approximately 10 days after the dilutions commenced during the $\mathrm{N}$-limited semicontinuous experiments (beginning of Phase III) and it was during this time that the photosynthetic efficiency $\left(F_{v} / F_{m}\right)$ increased (Figure 3.11 C.). A similar observation was observed in nitrogen-limited continuous cultures of Thalassiosira pseudonana where the $F_{v} / F_{m}$ (DCMU ratio) remained high and unaffected by different nitrogen-limited specific growth rates (Cullen et al. 1992). However, the results of Kolber et al. (1988) showed that the quantum yield and the $\mathrm{F}_{\mathrm{v}} / \mathrm{F}_{\mathrm{m}}$ ratio decreased for three diatom species during balanced growth/steady state in nitrogen $\left(\mathrm{NH}_{4} \mathrm{Cl}\right)$ limited chemostats, which was similar to $\mathrm{N}$-starved (unbalanced growth) observations made during this study. However, the results obtained by Kolber et al. (1988) could not be reproduced, so the conflicting results could be due to differences in experimental design or nitrogen source. 
The increase in $\mathrm{F}_{\mathrm{v}} / \mathrm{F}_{\mathrm{m}}$ during semi-continuous $\mathrm{N}$-acclimation resembles the changes that occurred during Phase II of the first mesocosm experiment. After the initial $\mathrm{N}$-starvation event in the mesocosm (Phase I), the intracellular chemical composition stabilized after Day 10, resembling $N$-acclimated growth. The slow increase in the $F_{v} / F_{m}$ after Day 10 suggests that acclimation was occurring during this period (MacIntyre et al. 1997; Parkhill et al., in prep). I hypothesize that the gradual decrease of nitrate in the top $60 \mathrm{~cm}$ of the mesocosm through time (Figure 3.1), was large enough to support $\mathrm{N}$-limited growth of cells in the surface layer. Some nitrate was most likely transported to the surface of the mesocosm by the physical disturbances that result from cell harvesting and the convection of nitrate along the side of the mesocosm from above the thermocline. Therefore, the cells in the surface layer presumably acclimated to low nitrate supply. The physiology of the cell reflected these changes, mimicking the conditions observed dúring $\mathrm{N}$-acclimated semi-continuous culture. Although the physiological changes were significant these intracellular modifications did not induce DVM behavior.

Toxins. Toxin content and composition are other important aspects of Alexandrium intracellular biochemistry that respond to changes in nutrient availability, including nitrogen. PSP toxins are N-rich compounds that can comprise up to $5-10 \%$ of the total cellular $\mathrm{N}$ in Alexandrium spp. (Cembella 1998). The degree to which nutrient limitation effects cellular toxicity during natural blooms is unknown, but toxin production and content have been shown to decrease in nitrogen stressed laboratory cultures (Boyer et al. 1985; Boyer et al. 1987; Anderson et al. 1990a; Anderson et al. 1990b; MacIntyre et al. 1997). 
A decline in cellular toxin content during $\mathrm{N}$-depletion was observed during Phase II of the first mesocosm experiment. During Phase III, upon release for $\mathrm{N}$-stress, a rapid increase in toxin content occurred (Figure 3.5). Similar rapid increases in toxin synthesis have also occurred in Alexandrium minutum upon nitrogen refeeding after periods of $\mathrm{N}$ stress (Flynn et al. 1994).

In contrast to the changes in toxin content, toxin composition of Alexandrium has long been considered a stable feature of different isolates when cultured using a wide range of different nitrogen concentrations, temperatures and salinities in batch culture (Boyer et al. 1987; Cembella et al. 1987; Ogata et al. 1987; Ogata et al. 1987). Therefore, toxin composition has been used as a chemotaxonomic character that distinguishes isolates of Alexandrium from different geographic regions (Cembella et al. 1987; Anderson et al. 1994). Only recently have changes in Alexandrium toxin composition been observed during growth in batch culture (late stationary phase) (Boczar et al. 1988), over the cell cycle and in $\mathrm{N}$ - and P-limited semi-continuous cultures (Anderson et al. 1990b; MacIntyre et al. 1997; Taroncher-Oldenburg et al. 1997).

The conflicting results between toxin composition measured during $\mathrm{N}$-starved batch cultures and $\mathrm{N}$-limited semi-continuous cultures are most likely due to experimental design and the physiological differences between $\mathrm{N}$-starved unbalanced and $\mathrm{N}$-limited balanced growth. Periods of N-starvation, as observed in batch cultures, may not be long enough to induce changes in the toxin composition before cell growth stops and nitrogen levels are undetectable (MacIntyre et al. 1997), whereas, in semi-continuous culture the limiting but continuous supply of $\mathrm{N}$ permits cell growth to continue, allowing time for 
intracellular modifications to occur, including changes in toxin composition. This gradual change in toxin content and composition was observed during the transition between Phase I and II of the first mesocosm experiment. Although nitrate was depleted by Day 2 in the surface layer, the toxin content did not decrease substantially until Phase II. This decrease was also apparent for many of the toxin derivatives (Figure 3.5).

It should be noted that the lack of toxin compositional changes in $\mathrm{N}$-starved batch culture experiments may also reflect the toxin composition of the particular Alexandrium isolate used. For example, during this study and the semi-continuous N- and P-limited experiments conducted by Anderson et al. (1990b), the C-toxins, gonyautoxins (GTX), STX and NEO were dominant, whereas in other isolates, these toxins may not be present or are in low abundance. Changes observed during $\mathrm{N}$-limitation for isolates from the Gulf of Maine may not occur in other strains of Alexandrium.

The mesocosm results in this study and the $\mathrm{N}$-limited semi-continuous results of MacIntyre et al. (1997) and Anderson et al. (1990b) demonstrate that the toxin composition of Alexandrium changes dramatically during $\mathrm{N}$-deplete and $\mathrm{N}$-acclimated conditions (Figure 3.5). The absolute toxin concentrations ( $\mathrm{fmol} \mathrm{cell}{ }^{-1}$ ) of $\mathrm{C} 1,2$, STX, NEO, GTX2,3, and GTX 1\& 4 decreased during the mesocosm and in Anderson et al. (1990) as the cells adapted to $\mathrm{N}$-limited conditions (Figures $3.5 \& 14$ ). Toxin derivatives can also be compared on a relative basis as the derivative mole percent total toxin (Figure 3.6). The most significant change in all three studies in this regard was a rapid decrease in the mole percent of STX during N-limited conditions. However, the mole percent total toxin of GTX 1,4 increased in both the mesocosm and Anderson et al (1990b). A few incon- 
sistencies were also observed, $\mathrm{C} 1,2$ (mole $\%$ total toxin) decreased during the mesocosm experiment, but increased in both Anderson et al. (1990b) and MacIntyre et al. (1997). In addition, NEO (mole \% total toxin) increased in both the mesocosm and MacIntyre et al. (1997), but decreased during Anderson et al. (1990b).

The conflicting results obtained between these sets of toxin data using derivative mole $\%$ total toxin is likely due to the large decrease in total toxin content under $\mathrm{N}$ limitation and the initial toxin compositional differences between the isolates used. As the total toxin content decreases, the proportions of each derivative become very small and variations among the different toxins can be difficult to discern. In such cases, the relative amounts of the different toxins are better compared using their actual concentrations (fmol cell-1) in order not to distort the real changes in composition occurring in the cell (compare Figures 3.5 and 3.6). This does not invalidate the use the mole $\%$ representations, but implies that changes in physiology of toxin interconversions can only be inferred from the absolute values of toxin cell quota for each derivative (TaroncherOldenburg et al. 1999).

Due to the significant differences in toxin composition and content between $\mathrm{N}-$ and P-limited semi-continuous culture (Figure 3.14), it is possible to identify diagnostic toxin ratios that define the different nutritional states, $\mathrm{N}$ - or P-limitation. The toxin ratios, C1,2:STX, GTX1,4:STX, NEO:STX, GTX2,3:STX and GTX1,4:NEO calculated from Anderson et al. 1990 increase dramatically as N-limitation increases (Figure 3.14 A), whereas, during phosphate limitation GTX2,3:NEO and GTX2,3:STX increase (Figure 3.14 B). Similar increases in C1,2:STX, GTX1,4:STX, NEO:STX, GTX2,3:STX in- 
dicative of $\mathrm{N}$-limitation were observed during Phase I of the mesocosm experiment (Figure $3.7 \mathrm{~A}$ ) while other ratios decreased (Figure $3.7 \mathrm{~B}$ ). As the cells adapted to the low nitrogen concentrations at the surface of the mesocosm, the toxin profiles and toxin ratios stabilized during the latter part of Phase II, emphasizing N-acclimation (Figures $3.6 \&$. 3.7). The rapid decrease in the toxin ratios as cells were released from nitrogen stress during Phase III demonstrates that these ratios are sensitive and robust indicators of $\mathrm{N}$ status as long as the cells had previously acclimated to the $\mathrm{N}$-limited conditions.

The combined use of toxin ratios and toxin content could potentially be used to identify and distinguish between different nutrient limited conditions (nitrogen vs. phosphorous). With additional experimentation that examines the toxin changes in Casco Bay isolates in semi-continuous culture during $\mathrm{N}$ - and P-limiting conditions, these nutritionally induced modifications in the toxin composition could provide a unique indicator of A. fundyense physiological status not only in laboratory cultures, but within natural field assemblages. 
FIGURE 3.14. Toxin composition (absolute concentration) and toxin ratios of Alexandrium fundyense (strain GTCA29) as a function of specific growth rate in N- and P- limited semi-continuous culture, recalculated from data Anderson et al. (1990b). (Panel A I) toxin composition (absolute concentration) in N-limited cultures ( $\left.\mathrm{fmol} \mathrm{cell}{ }^{-1}\right) \mathrm{C} 1,2(\mathrm{O})$,

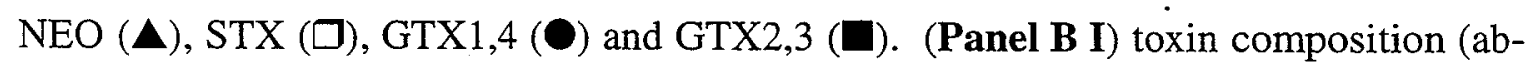
solute concentration) in P-limited cultures (fmol cell ${ }^{-1}$ ) - see symbols in (Panel A I). (Panel A II \& A III) toxin ratios (fmol:fmol) in semi-continuous N-limited cultures NEO:STX (O), GTX1,4:STX (४), C1,2:STX (ロ), GTX2,3:STX (•), GTX1,4:NEO (•), C1,2:NEO $(\Delta)$, C1,2:GTX1,4 $(\diamond)$ and GTX2,3:NEO $(\mathbf{\square}),($ Panel B II \& B III) toxin ratios (fmol:fmol) for P-limited cultures - see symbols in Panel A II \& A III. 
$\mathrm{NO}_{3}{ }^{-}$Limited
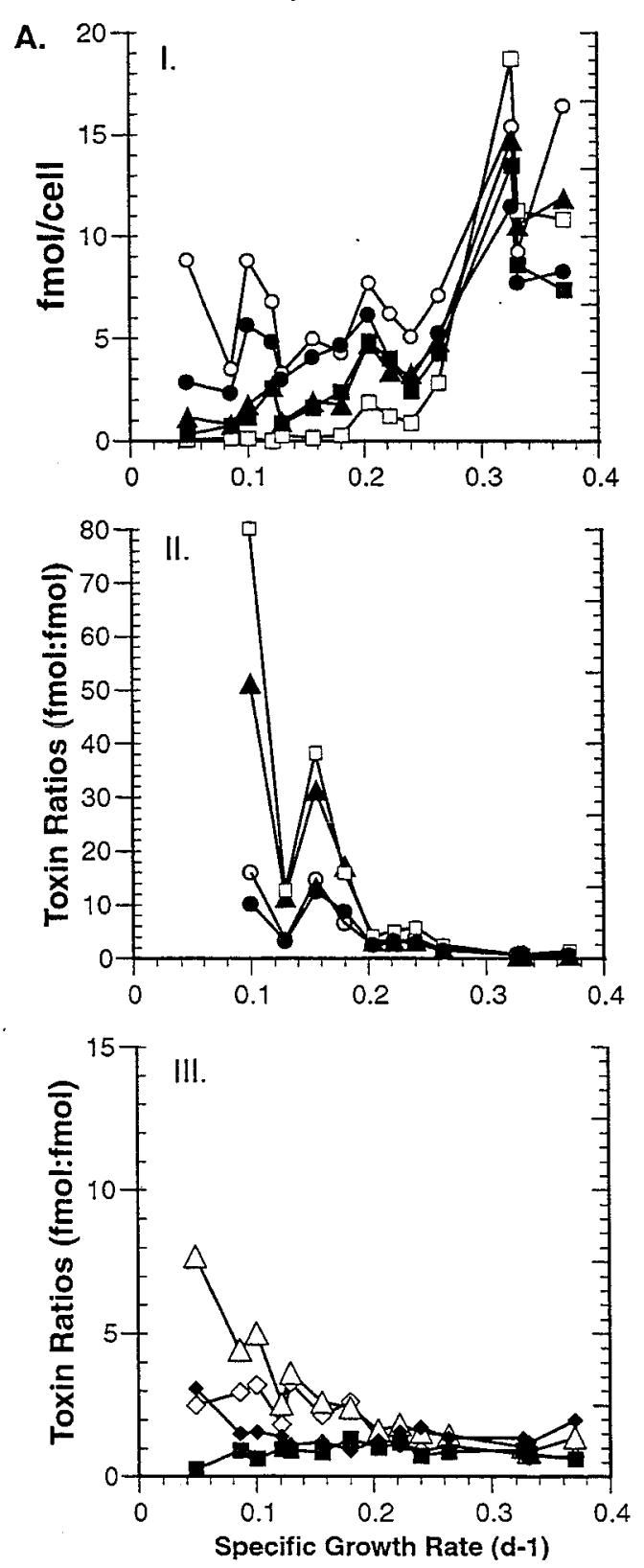

$\mathrm{PO}_{4}^{3 \cdot}$ Limited
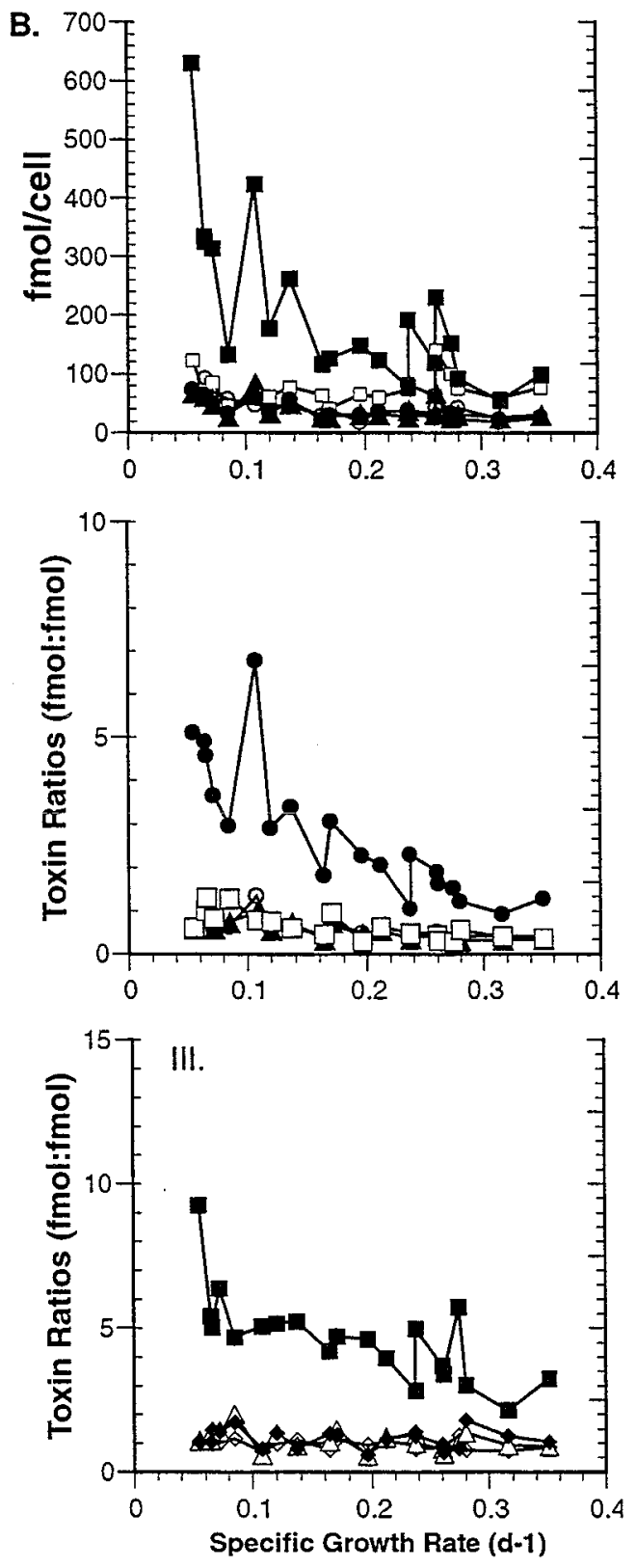
Although the effects of salinity, irradiance and temperature on the cellular toxin composition in batch culture are minimal (Ogata et al. 1987; Parkhill and Cembella 1999), more experimental studies are required to verify that these external factors would not cause misinterpretations of the results. Depending on the Alexandrium isolate or region to be examined, the changes in toxin composition under different external conditions would need to be tested in laboratory isolates since there is widespread variation in composition that could cause changes in nutritional response from region to region (Cembella et al. 1987; Anderson et al. 1994). Since the toxin profiles of Alexandrium isolates from the Gulf of Maine have similar toxin compositions, including isolates from Casco Bay, ME (Anderson et al. 1994), these experimental results suggest that toxin diagnostic ratios may be useful as potential indicators of $\mathrm{N}$-nutritional status of Alexandrium in the coastal waters of the Gulf of Maine or specifically, Casco Bay, Maine. This potential is explored in Chapter 4.

Diagnostics of $N$-status. Based on the results presented here and in previous studies by MacIntyre et al. (1997), and Anderson et al. (1990a, 1990b) indicators of N-nutritional status can be inferred from the intracellular chemical and toxin composition of Alexandrium in culture. Nutritional variation in the environment during a spring bloom can be quite dramatic, causing intermittent exposure to limiting environmental variables, including light and temperature. With a combination of the cellular physiological characteristics identified in this study, and the use of as toxin content and toxin composition ratios it is possible to discern patterns of $\mathrm{N}$-status for $\mathrm{N}$-replete, $\mathrm{N}$-starved, and $\mathrm{N}$-limited 
Alexandrium cells in culture and potentially field populations. Of the $\mathrm{N}$-indicators identified in this paper the toxin ratios are a specific marker for Alexandrium and can be isolated and quantified from field populations without the need for cell separation.

With regard to the other $\mathrm{N}$-nutritional indicators identified in this paper such as C:N \& $F_{v} / F_{m}$, new detection methods in the field for obtaining individual cell measurements, will soon be possible in order to isolate and determine the effects of the changing environmental conditions on Alexandrium in the field. Such separation methods may include the use of manual micropipeting, flow cytometry (Chisholm et al. 1986) or immunomagnetic bead separation as discussed in Chapter 2. However, it must be stressed that the nutrient diagnostics identified in this study only examined the intracellular effects of one environmental variable, nitrate supply. Both irradiance and temperature are also known to effect the intracellular chemical composition of cells, as discussed previously where some of the changes that occur during nutrient limitation can mimic the effects of high irradiance and low temperature. Therefore, it is necessary to combine indicators to positively identify changes in nutrient status. 


\section{ACKNOWLEDGEMENTS}

We would like thank many members of the Cullen laboratory (past and present), Gary Maillet, Richard Davis, Jean-Paul Parkhill, and Yaohong Zhang for help during the intensive sampling periods required during the laboratory water column and semi-continuous experiments and Cathy Ryan who provided technical assistance for the CHN analysis. Thanks to Dave Kulis for helpful discussions and technical assistance with the HPLC toxin analysis. This work was supported by U.S. ECOHAB Program National Science Foundation Grant OCE - 9808173, NOAA Grant NA960P0099 and the EPA Star Graduate Fellowship (\# U-915038-01-0) with additional support from NSERC Research Partnership. Contribution No. \#\# from the Woods Hole Oceanographic Institution, and Contribution \# from the U.S. ECOHAB Program, sponsored by NOAA, NSF, EPA, NASA, and ONR. 


\section{REFERENCES}

Aguilera, A., S. Gonzalez-Gil, B. A. Keafer and D. M. Anderson (1996). "Immunomagnetic separation of cells of the toxic dinoflagellate Alexandrium fundyense from natural plankton samples." Mar. Ecol. Prog Ser. 143: 255-269.

Aguilera, A., B. A. Keafer, G. H. Rau and D. M. Anderson (in press). "Immunomagnetic isolation of live and preserved Alexandrium fundyense cells: Species-specific physiological, chemical, and isotopic analyses." Mar. Ecol. Prog. Ser.

Anderson, D. M. and K. D. Stolzenbach (1985). "Selective retention of two dinoflagellates in a well-mixed estuarine embayment: the importance of diel vertical migration and surface avoidance." Mar. Ecol. Prog, Ser. 25: 39-50.

Anderson, D. M. (1989). Toxic algal blooms and red tides: A global perspective. In: T. Okaichi, D. M. Anderson and T. Nemoto (eds.) Red Tides: Biology, Environmental Science, and Toxicology. pp. 11-16. Elsevier.

Anderson, D. M., D. M. Kulis, J. J. Sullivan, S. Hall and C. Lee (1990a). "Dynamics and physiology of saxitoxin production by the dinoflagellates Alexandrium spp." Mar. Biol. 104: 511-524.

Anderson, D. M., D. M. Kulis, J. J. Sullivan and S. Hall (1990b). "Toxin composition variations in one isolate of the dinoflagellate Alexandrium fundyense." Toxicon 28(8): 885-893.

Anderson, D. M., D. M. Kulis, G. J. Doucette, J. C. Gallagher and E. Balech (1994). "Biogeography of toxic dinoflagellates in the genus Alexandrium from the northeastern United States and Canada." Mar. Biol. 120: 467-478.

Anderson, D. M. (1997). "Bloom dynamics of toxic Alexandrium species in the northeastern U.S." Limnol. Oceanogr. 42(5, part 2): 1009-1022.

Bannister, T. T. and E. A. Laws (1980). Modeling phytoplankton carbon metabolism. In: P. G. Falkowski Primary Productivity in the Sea. pp. 243-258. Plenum Press. 
Bhovishitra, M. and E. Swift (1977). "Light and dark uptake of nitrate and ammonium by large oceanic dinoflagellates: Pyrocystis noctiluca, Pyrocystis fusiformis, and Dissodinium lunula." Limnol. Oceanogr. 22: 73-83.

Blasco, D. (1978). "Observations on the diel migration of marine dinoflagellates off the Baja California Coast." Mar. Biol. 46: 41-47.

Boczar, B. A., M. K. Beitler, J. Liston, J. J. Sullivan and R. A. Cattolico (1988). "Paralytic shellfish toxins in Protogonyaulax tamarensis and Protogonyaulax catenella in axenic culture." Plant Physiol. 88: 1285-1290.

Boyer, G. L., P. J. Harrison and F. J. R. Taylor (1985). Toxin production in three isolates of Protogonyaulax sp. In: D. M. Anderson, A. W. White and D. G. Baden (eds.) Toxic Dinoflagellates. pp. 281-286. Elsevier.

Boyer, G. L., J. J. Sullivan, R. J. Andersen, P. J. Harrison and F. J. R. Taylor (1987). “Effects of nutrient limitation on toxin production and composition in the marine dinoflagellate Protogonyaulax tamarensis." Mar. Biol. 96: 123-128.

Cembella, A. D., J. J. Sullivan, G. L. Boyer, F. J. R. Taylor and R. J. Andersen (1987). "Variation in paralytic shellfish toxin composition within the Protogonyaulax tamarensis/catenella species complex: red tide dinoflagellates." Biochem. System. Ecol. 15: 171-186.

Cembella, A. D. (1998). Ecophysiology and metabolism of paralytic shellfish toxins in marine microalgae. In: D. M. Anderson, A. D. Cembella and G. M. Hallegraeff (eds.) Physiological Ecology of Harmful Algal Blooms. Springer-Verlag. G 41: 381-403.

Chisholm, S. W., E. V. Armbrust and R. J. Olson (1986). The individual cell in phytoplankton ecology: cell cycles and applications to flow cytometry. In: T. Platt and W. K. W. Li (eds.) Photosynthetic picoplankton. Can. Bull. Fish. and Aquatic Sci. 214: 343-369.

Cleveland, J. S. and M. J. Perry (1987). "Quantum yield, relative specific absorption and fluorescence in nitrogen-limited Chaetoceros gracilis." Mar. Biol. 94: 489-497.

Cuhel, R. L., P. B. Ortner and D. R. S. Lean (1984). "Night synthesis of protein by algae." Limnol. Oceanogr. 29(4): 731-744. 
Cullen, J. J. and S. G. Horrigan (1981). "Effects of nitrate on the diurnal vertical migration, carbon to nitrogen ratio, and the photosynthetic capacity of the dinoflagellate, Gymnodinium splendens." Mar. Biol. 62: 81-89.

Cullen, J. J. (1985). Diel vertical migration by dinoflagellates: roles of carbohydrate metabolism and behavioral flexibility. In: M. A. Rankin (ed.) Migration: Mechanisms and Adaptive Significance. Cont. Mar. Sci. 27: 135-152.

Cullen, J. J., M. Zhu, R. F. Davis and D. C. Pierson (1985). Vertical migration, carbohydrate synthesis and nocturnal uptake during growth of Heterocapsa niei in a laboratory column. In: D. M. Anderson, A. W. White and D. G. Baden (eds.) Toxic Dinoflagellates. pp. 189-194. Elsevier.

Cullen, J. J., X. Yang and H. L. MacIntyre (1992). Nutrient limitation of marine photosynthesis. In: P. G. Falkowski and A. D. Woodhead (eds.) Primary Productivity and Biogeochemical Cycles in the Sea. pp. 69-88. Plenum Press.

Cullen, J. J. and J. G. MacIntyre (1998). Behavior, physiology and the niche of depthregulating phytoplankton. In: D. M. Anderson, A. D. Cembella and G. M. Hallegraeff (eds.) The Physiological Ecology of Harmful Algal Blooms. Springer-Verlag. G 41: 559-579.

Dorsey, T. E., P. MacDonald and O. A. Roels (1978). "Measurement of phytoplankton protein content with the heated biuret folin assay." J. Phycol. 14: 167-171.

Dubois, M., K. A. Gilles, J. K. Hamilton, P. A. Rebers and F. Smith (1956). "Colorimetric method for determination of sugars and related substances." Analytical Chem. 28: 350-356.

Entsch, B., R. G. Sim, B. G. Hatcher. (1983) "Indications from photosynthetic components that iron is a limiting nutrient in primary producers on coral reefs." Mar. Biol. 73: $17-30$.

Eppley, R. W., O. Holm-Hansen and J. D. H. Strickland (1968). "Some observations on the vertical migration of dinoflagellates." J. Phycol. 4(333-340). 
Eppley, R. W. and W. G. Harrison (1975). Physiological ecology of Gonyaulax polyedra. a red water dinoflagellate of southern California. 1st International Conference on Toxic Dinofagellate Blooms, Wakefield, MA.

Eppley, R. W. (1981). Relations between nutrient assimilation and growth in phytoplankton with a brief review of estimates of growth rate in the ocean. In: T. Platt (ed.) Physiological Bases of Phytoplankton Ecology. Can. Bull. Fish. Aquat. Sci. 210: 251-263.

Erdner, D. L. and D. M. Anderson (1999). "Ferredoxin and flavodoxin as biochemical indicators of iron limitation during open-ocean iron enrichment." Limnol. Oceanogr. 44(7): 1609-1615.

Erdner, D. L., N. M. Price, G. J. Doucette, M. L. Peleato and D. M. Anderson (1999). "Characterization of ferredoxin and flavodoxin as marker of iron limitation in marine phytoplankton." Mar. Ecol. Prog. Ser. 184: 43-53.

Falkowski, P. and D. A. Kiefer (1985). "Chlorophyll $a$ fluorescence in phytoplankton: relationship to photosynthesis and biomass." J. Plankton Res. 7: 715-731.

Falkowski, P. G., R. M. Greene and R. J. Geider (1992). "Physiological limitations on phytoplankton productivity in the ocean." Oceanography 5(2): 84-91.

Flynn, K. J., D. M. J. Dickson and O. A. Al-Amoudi (1989). "The ratio of glutamate:glutamine in microalgae; a biomarker for $\mathrm{N}$-status suitable for use at natural cell densities." J. Plankton Res. 11: 165-170.

Flynn, K., J. M. Franco, P. Fernandez, B. Reguera, M. Zapata, G. J. Wood and K. J. Flynn (1994). "Changes in toxin content, biomass and pigments of the dinoflagellate Alexandrium minutum during nitrogen refeeding and growth into nitrogen or phosphorous stress." Mar. Ecol. Prog. Ser. 111: 99-109.

Flynn, K., K. J. Jones and K. J. Flynn (1996). "Comparisons among species of Alexandrium (Dinophyceae) grown in nitrogen- or phosphorous-limiting batch culture." Mar. Biol. 126: 9-18. 
Franks, P. J. S. and D. M. Anderson (1992). "Alongshore transport of a toxic phytoplankton bloom in a buoyancy current: Alexandrium tamarense in the Gulf of Maine." Mar. Biol. 112: 153-164.

Geider, R. J., H. L. MacIntyre and T. M. Kana (1996). "A dynamic model of photoadaptation in phytoplankton." Limnol. Oceanogr. 41(1): 1-15.

Geider, R. J., H. L. MacIntyre and T. M. Kana (1997). "Dynamic model of phytoplankton growth and acclimation: responses of the balanced growth rate and the chlorophyll a:carbon ratio to light, nutrient-limitation and temperature." Mar. Ecol. Prog. Ser. 148: $187-200$.

Geider, R. J., H. L. MacIntyre and T. M. Kana (1998). "A dynamic regulatory model of phytoplanktonic acclimation to light, nutrients, and temperature." Limnol. Oceanogr. 43(4): 679-694.

Geraci, J. A., D. M. Anderson, R. J. Timperi, D. J. S. Aubin, G. A. Early, J. A. Prescott and C. A. Mayo (1989). "Humpback whales (Megaptera novaeangliae) fatally poisoned by dinoflagellate toxin." Can. J. Fish. Aquat. Sci. 46: 1895-1898.

Grasshoff, K., M. Ehrhardt and K. Kremling (1976). Methods of seawater analysis. Weinheim, Verlag Chemie.

Greene, R. M., R. J. Geider and P. G. Falkowski (1991). "Effect of iron limitation on photosynthesis in a marine diatom." Limnol. Oceanogr. 36: 1772-1782.

Hall, S. (1982). Toxins and toxicity of Protogonyaulax from the Northeast Pacific. , University of Alaska, Fairbanks, p. 196.

Hallegraeff, G. M. (1993). "A review of harmful algal blooms and their apparent global increase." Phycologia 32: 79-99.

Harrison, W. G. (1976). "Nitrate metabolism of the red tide dinoflagellate Gonyaulax polyhedra stein." J. exp. mar. Biol. Ecol. 21: 199-209.

Heaney, S. I. and R. W. Eppley (1981). "Light, temperature and nitrogen as interacting factors affecting diel vertical migrations of dinoflagellates in culture." J. Plankton Res. 3(2): 331-344. 
John, E. H. and K. J. Flynn (1999). "Growth dynamics and toxicity of Alexandrium fundyense (Dinophyceae): the effect of changing $\mathrm{N}: \mathrm{P}$ supply ratios on internal toxin and nutrient levels." Eur. J. Phycol.: 11-23.

Kamykowski, D. and S.-J. Zentara (1976). "The diurnal vertical migration of motile phytoplankton through temperature gradients." Limnol. Oceanogr.: 148-151.

Kamykowski, D. (1995). “Trajectories of autotrophic marine dinoflagellates.” J. Phycol. 31: 200-208.

Kamykowski, D. (1998). "Relationships between geotaxis/phototaxis and diel vertical migration in autotrophic dinoflaglellates." J. Plankton Res. 20:1781-1796.

Kamykowski, D., H. Yamazaki, A. K. Yamazaki and G. J. Kirkpatrick (1998). A comparison of how different orientation behaviors influence dinoflagellate trajectories and photoresponses in turbulent water columns. In: D. M. Anderson, A. D. Cembella and G. M. Hallegraeff (eds.) Physiological Ecology of Harmful Algal Blooms. Springer-Verlag. G 41:581-599.

Kamykowski, D., E. J. Milligan, R. R. Reed, and W. Liu. (1999). "Geotaxis/phototaxis and biochemical patterns in Heterocapsa (=Cachonina) illdefina (Dinophyceae) during diel vertical migrations." J. Phycol. 35(6) suppl.: 1397-1403.

Keller, M. D., R. C. Selvin, W. Claus and R. R. L. Guillard (1987). "Media for the culture of oceanic ultraplankton." J. Phycol. 23: 633-638.

Kolber, Z., J. Zehr and P. G. Falkowski (1988). "Effects of growth irradiance and nitrogen limitation on photosynthetic energy conversion in photosystem II." Plant Physiol. 88: 923-929.

LaRoche, J., R. J. Geider, L. M. Graziano, H. Murray and K. Lewis (1993). "Induction of specific proteins in eukaryotic algae grown under iron-, phosphorous-, or nitrogendeficient conditions." J. Phycol. 29: 767-777.

LaRoche, J., P. W. Boyd, R. M. McKay and R. J. Geider (1996). "Flavodoxin as an in situ marker for iron stress in phytoplankton." Nature 382: 802-805.

Levasseur, M., J. C. Therriault and L. Legendre (1984). "Hierarchical control of phytoplankton succession by physical factors." Mar. Ecol. Prog. Ser. 19: 211-222. 
Lowry, O. H., N. J. Rosebrough, A. L. Farr and R. J. Randall (1951). "Protein measurement with the folin phenol reagent." J. Biol. Chem. 193: 265-275.

MacIntyre, J. G., J. J. Cullen and A. D. Cembella (1997). "Vertical migration, nutrition and toxicity in the dinoflagellate Alexandrium tamarense." Mar. Ecol. Prog. Ser. 148: 201-216.

Maestrini, S. Y. and D. J. Bonin (1981). Competition among phytoplankton based on inorganic macronutrients. In: T. Platt (ed.) Physiological Bases of Phytoplankton Ecology. Can. Bull. Fish. Aquat. Sci. 210: 264-278.

Maranda, L., D. M. Anderson and Y. Shimizu (1985). "Comparision of toxicity between populations of Gonyaulax tamarensis of eastern North American waters." Estuar. Coast. Shelf Sci 21: 401-410.

Margalef, R. (1978). "Life-forms of phytoplankton as survival alternatives in an unstable environment." Oceanologica Acta 1: 493-509.

Margalef, R., M. Estrada and D. Blasco (1979). Functional morphology of organisms involved in red tides, as adapted to decaying turbulence. In: M. Taylor and H. H. Seliger (eds.) Toxic Dinoflagellate Blooms. pp.89-94, Elsevier:

Martin, J. L. and A. W. White (1988). "Distribution and abundance of the toxin dinoflagellate Gonyaulax excavata in the Bay of Fundy." Can. J. Fish. Aquat. Sci. 45: 19681975.

Martorano, C. D. (1997). MSc. Nutrient dynamics during blooms of Alexandrium spp. in the southwestern Gulf of Maine._ University of New Hampshire, Durham, NH, p.132.

Ogata, T., T. Ishimaru and M. Kodama (1987). "Effect of water temperature and light intensity on growth rate and toxicity change in Protogonyaulax tamarensis." Mar. Biol. 95: 217-220.

Ogata, T., M. Kodama and T. Ishimaru (1987). "Toxin production in the dinoflagellate Protogonyaulax tamarensis." Toxicon 25: 923-928.

Oshima, Y., S. I. Blackburn and G. M. Hallegraeff (1993). "Comparative study on paralytic shellfish toxin profiles of the dinoflagellate Gymnodinium catenatum from three different countries." Mar. Biol. 116: 471-476. 
Oshima, Y., T. Hayakawa, M. Hashimoto, Y. Kotaki and T. Yasumoto (1982). "Classification of Protogonyaulax tamarensis form northern Japan into three strains by toxin composition.” Bull. Jpn. Soc. Scient. Fish. 48: 851-854.

Oshima, Y. S., K. Sugino and T. Yasumoto (1989). Latest advances in HPLC analysis of paralytic shellfish toxins. Mycotoxins and phycotoxins: Proc. 7th IUPAC Symposium.

Paasche, E., I. Bryceson and K. Tangen (1984). "Interspecific variation in dark nitrogen uptake by dinoflagellates." J. Phycol. 20: 394-401.

Parkhill, J. P. and A. D. Cembella (1999). "Effects of salinity, light and inorganic nitrogen on growth and toxigenicity of the marine dinoflagellate Alexandrium tamarense from northeastern Canada." J. Plankton Res 21: 939-955.

Passow, U. (1991). "Vertical migration of Gonyaulax catenata and Mesodinium rubrum." Mar. Biol. 110: 455-463.

Rasmussen, J. and K. Richardson (1989). "Response of Gonyaulax tamarensis to the presence of a pycnocline in an artificial water column." J. Plankton Res. 11(4): 747762.

Ryther, J. H. and W. M. Dunstan (1971). "Nitrogen, phosphorous, and eutrophication in the coastal marine environment." Science 171: 1008-1013.

Sakshaug, E. and O. Holm-Hansen (1977). "Chemical composition of Skeletonema costatum (Grev.) Cleve and Ravlava (Monochrysis) lutheri (Droop) Green as a function of nitrate- phosphate- and iron-limited growth." J. Exp. Mar. Biol. Ecol. 29: 1-34.

Santos, B. A. and J. I. Carreto (1992). "Migraciones verticales de Alexandrium excavatum (Braarud) Balech et Tangen en columnas experimentales." Bolm Inst Oceanogr. S Paulo 40(1/2): 15-25.

Shimizu, Y. (1993). “Microalgal metabolites.” Chem. Rev. 93: 1685-1698.

Shuter, B. (1979). "A model of physiological adaptation in unicellular algae." J. theor. Biol. 78: 519-552.

Strickland, J. D. H. and T. R. Parsons (1972). “A practical handbook of seawater analysis, 2nd edn." Bull. Fish. Res. Bd. Can. 167: 1-310. 
Taroncher-Oldenburg, G., D. M. Kulis and D. M. Anderson (1997). "Toxin variability during the cell cycle of the dinoflagellate Alexandrium fundyense." Limnol. Oceanogr. 42: 1178-1188.

Taroncher-Oldenburg, G., D. M. Kulis and D. M. Anderson (1999). "Coupling of saxitoxin biosynthesis to the $\mathrm{G} 1$ phase of the cell cycle in the dinoflagellate Alexandrium. fundyense: temperature and nutrient effects." Natural Toxins 7: 207-219.

Therriault, J. C., J. Painchaud and M. Lavasseur (1985). Factors controlling the occurrence of Protogonyaulax tamarensis and shellfish toxicity in the St. Lawrence estuary: Freshwater runoff and the stability of the water column. In: D. M. Anderson, A. White and D. Baden (eds.) Toxic Dinoflagellates. pp. 141-146. Elsevier.

Utermöhl, H. (1958). "Neue Wege in der quantitativen Erfassung des Planktons (mit besonderer Berücksichtigung des Ultraplanktons." Verh. int. Ver. theor. angew. Limnol. 5: 567-596.

Vrieling, E. G., R. P. T. Koeman, K. Nagasaki, Y. Ishida, L. Peperzak, W. W. C. Gieskes and M. Veenhuis (1995). "Flow cytometric identification of the icthytoxic dinoflagellate Gydrodinium aureolum in the central North Sea." In: P. Lassus, G. Arzul, E. Erard, P. Gentien, and C. Marcaillou (eds.), Harmful Marine Algal Blooms, pp. 743748. Lavoisier.

Vrieling, E. G., R. P. T. Koeman, C. A. Scholin, P. Scheerman, L. Peperzak, M. Veenhuis, and W. W. C. Gieskes (1996). "Identification of a domoic acid-producing Pseudo-nitzschia species (Bacillariophyceae) in the Dutch Wadden Sea with electron microscopy and molecular probes." Eur. J. Phycol. 31: 333-340.

Welschmeyer, N. A. and C. J. Lorenzen (1981). "Chlorophyll-specific photosynthesis and quantum efficency at subsaturating light intensities." J. Phycol 17: $283-$.

White, A. W., O. Fukuhara and M. Anraku (1989). Mortality of fish larvae from eating toxic dinoflagellates or zooplankton containing dinoflagellate toxins. In: T. Okaichi, D. M. Anderson and T. Nemoto (eds.) Red Tides: Biology, Environmental Science and Toxicology. pp. 395-398. Elsevier. 


\section{CHAPTER 4}

TOXIN VARIABILITY IN NATURAL POPULATIONS OF ALEXANDRIUM

FUNDYENSE IN CASCO BAY, MAINE - EVIDENCE OF NITROGEN LIMITATION 


\section{INTRODUCTION}

One challenge in phytoplankton ecology is to measure a species' physiological responses to changes in environmental conditions. In the marine coastal environment, nitrogen and phosphorous ( $\mathrm{N}$ and $\mathrm{P}$ ) may be sufficient for a particular organism's needs, or be limiting and thus affect population development and species succession (Rhee 1978). It is thus of great importance to ascertain the nutritional status of a species of interest, but this is difficult due to the heterogeneity of species within the plankton. At present, most measurements of natural phytoplankton provide data on the entire community of organisms in a sample. Efforts to obtain species-specific data are particularly important for harmful algal bloom (HAB) species such as the toxic dinoflagellate Alexandrium fundyense which does not usually dominate the planktonic community, but is of great interest due to the potent toxins it produces. Clearly, indicators or responses to nutrient deprivation need to be identified that are specific to that one species or species complex.

One unique feature of many Alexandrium species that could potentially be exploited in this regard is that they are toxic, and that their toxicity has been shown to vary with nutritional conditions. Many Alexandrium species produce saxitoxin, a potent neurotoxin that causes paralytic shellfish poisoning (PSP) in many regions of the world (Hallegraeff 1993). The toxins produced are called saxitoxins, of which there are more than 20 known derivatives (Cembella 1998). Different species or strains of Alexandrium can produce different quantities and combinations of these toxins. The toxicity of Alexandrium spp. can thus be quantified in terms of: 1.) toxin content (the overall toxicity of 
the cell calculated as the sum of the molar content of each derivative, expressed as pmol cell $^{-1}$, or as the integrated potency of all saxitoxin (STX) derivatives present, expressed as STX equivalents $\mathrm{cell}^{-1}$ ); or 2.) toxin composition (the number and relative proportions of the STX derivatives in the cell; Hall 1982; Cembella et al. 1987; Anderson 1990).

Numerous studies have examined changes in toxin content and composition using batch cultures. The effects of varying single environmental parameters such as irradiance, temperature, salinity and inorganic nutrients ( $\mathrm{N}$ and $\mathrm{P}$ ) have all been shown to affect toxin content for several different Alexandrium strains. In particular, depletion of nitrogen $(\mathrm{N})$ causes toxin content to decrease in parallel with other general physiological changes that occur during $\mathrm{N}$-stress (i.e. chlorosis, increased $\mathrm{C}: \mathrm{N}$, and decreased protein content; White 1978; Boyer et al. 1987; Ogata et al. 1987; Anderson et al. 1990; Flynn et al. 1994; Flynn et al. 1996; Matsuda et al. 1996; Parkhill and Cembella 1999). Two exceptions to the decrease in toxin content during stress are growth under P-limited conditions and growth at sub-optimal temperatures. In both cases, toxin content increases dramatically (Hall 1982; Boyer et al. 1987; Anderson et al. 1990; Anderson et al. 1990; Flynn et al. 1994; Flynn et al. 1996). Since phosphate stress can affect amino acid and protein metabolism, it has been proposed (Anderson 1990; Flynn et al. 1994) that Pstressed cells may allocate the nitrogen that cannot be used for proteins toward saxitoxin production (a nitrogen-rich compound).

Based on results from batch culture studies, toxin composition has been considered a stable feature - a fixed genetic trait which can be used to distinguish strains or species, as a biochemical fingerprint (Boyer et al. 1987; Anderson 1990; Sako et al. 1995; 
Matsuda et al. 1996; Cembella 1998). Indeed, during nutrient replete conditions in batch culture, toxin composition does appear to be invariant, and thus can serve as a chemotaxonomic marker for different Alexandrium strains (Cembella 1998). However, recent studies have shown that once cells are given time to achieve steady state in semicontinuous, nutrient-limited cultures, toxin composition does vary during progressive $\mathrm{N}$ and P-limitation (Anderson et al. 1990b; MacIntyre et al. 1997; Poulton et al. in prep.). Using either the absolute toxin abundance or relative proportion (mole \% total toxin) of each toxin derivative, $\mathrm{N}$ - and P-limitation can be distinguished easily based on the observed trends in the different STX derivatives.

This suggests that toxin composition could be used to assess the nutritional status of Alexandrium in field populations, as long as the changes in toxin composition of isolates from a particular region to different nutrient stress have been characterized. To date, modifications in toxin composition using nutrient limited semi-continuous culture have been characterized for A. fundyense strains from the Gulf of Maine and $A$. tamarense from the Gulf of St. Lawrence, Canada (Anderson et al. 1990; MacIntyre et al. 1997). However, extrapolating these results to other regions could be difficult since the toxin will vary depending on the initial toxin profile. To date, variability in toxin content and toxin composition of Alexandrium have not been examined in detail in field populations. In this study, we examine these toxin content and composition in natural $A$. fundyense populations during a spring bloom in Casco Bay, ME from April - June of 1998. This study allows us to examine whether Alexandrium populations in the western Gulf of Maine are sufficiently homogenous to permit toxin composition and content dif- 
ferences to be detected through time and space, and if so, to see whether those changes are indicative of a particular nutritional state (e.g., $\mathrm{N}$-limitation).

Table 4.1 List of definitions of abbreviations and acronyms.

\begin{tabular}{ll}
\hline Abbreviation & Definition \\
\hline chl $a$ & chlorophyll $a$ \\
PBS & phosphate buffered saline \\
NGS & normal goat serum \\
MAb & monoclonal antibody or antiserum \\
DMEM & Dubelccos Modified Eagle's Medium \\
IgG $_{1}$ & Immunoglobulin protein, subclass G \\
FCS & fetal calf serum \\
FITC & fluorecein isothiocyanate (green fluorochrome) \\
GAM & goat anti-mouse \\
BP & band pass \\
LP & long pass \\
PSP & Paralytic Shellfish Poisoning \\
STX & saxitoxin (group of toxins or derivative) \\
GTX & gonyautoxin \\
NEO & neosaxitoxin \\
C & C toxins \\
HCl & hydrochloric acid \\
HoAc & acetic acid \\
CHO & carbohydrate \\
TDN & total dissolved nitrogen \\
DON & dissolved organic nitrogen \\
DIN & dissolved inorganic nitrogen \\
VSW & Vineyard Sound seawater \\
\hline &
\end{tabular}

\section{MATERIALS AND METHODS}

This investigation was carried out during a 5-year study of the ecology and oceanography of toxic Alexandrium blooms in the Gulf of Maine (ECOHAB-GOM). This multidisciplinary study is exploring cell distributions and dynamics of Alexandrium blooms from the Bay of Fundy, Canada to Cape Ann, Massachusetts. The research presented here was part of a series of cruises conducted to understand the environmental regulation of toxic 
blooms and to characterize the environmental factors that govern their initiation, growth, maintenance, and termination.

Sampling. During the second year of the ECOHAB-GOM study, a series of 11 cruises . within Casco Bay in the western Gulf of Maine were carried out between April and June 1998, following three transects of 32 total stations that extended $20 \mathrm{~km}$ offshore (Figure 4.1). Depth profiles for temperature, salinity and in situ fluorescence were recorded using a Seabird CTD profiler with a SeaTech fluorometer and the data were initially processed using Seabird's software. Final processing to produce contours of the selected salinity, temperature, density and nutrient concentrations were processed using Matlab routines.

FIGURE 4.1. Chart of the Casco Bay Region along the Maine coast within the Gulf of Maine, showing the location of the sampling sites. Boxed sites represent locations where toxin samples were collected. 


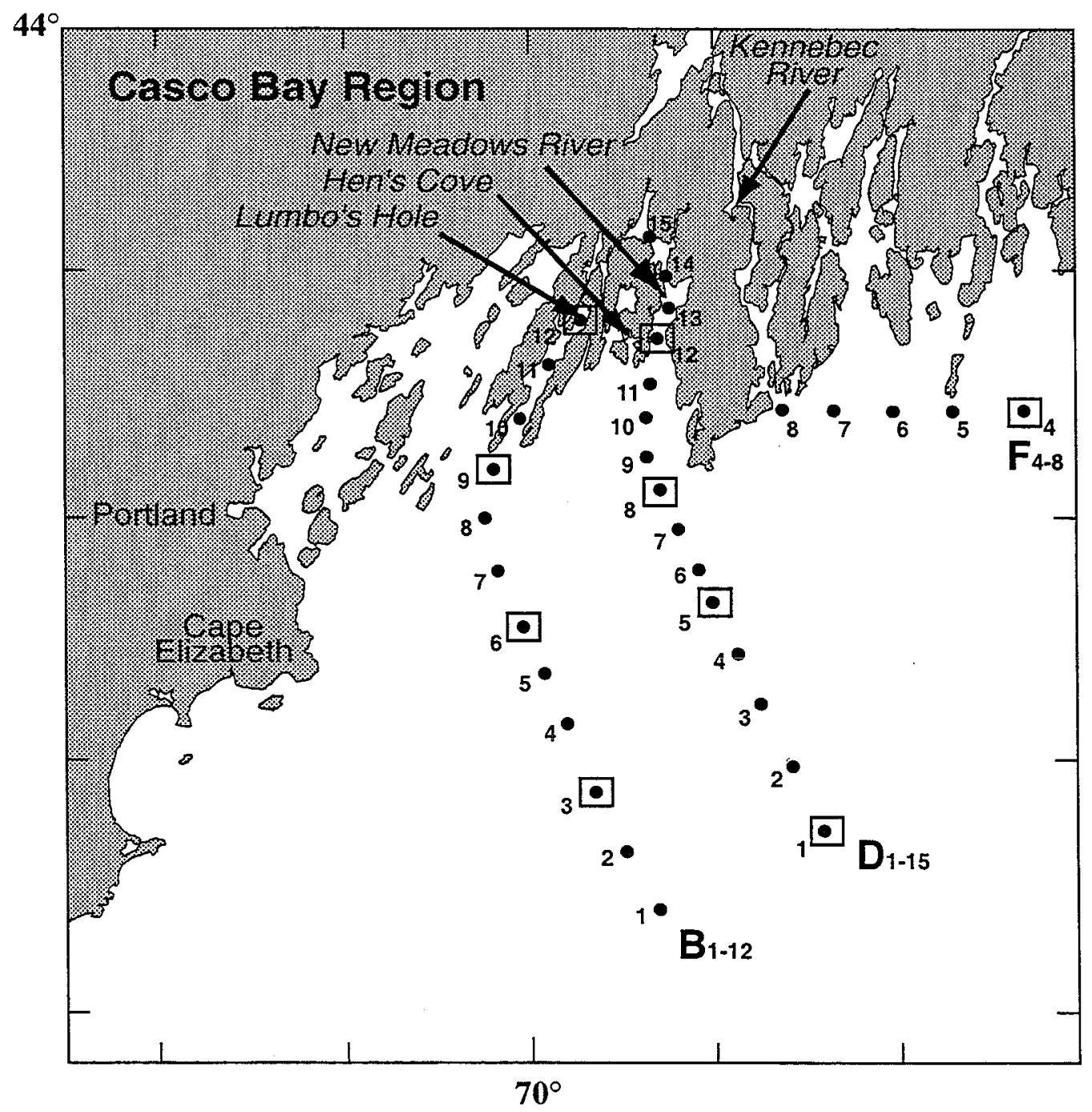


Samples for Alexandrium abundance and nutrients were collected from Niskin bottles at the surface $(1 \mathrm{~m}), 3.5,7,10$ and $20 \mathrm{~m}$ at all stations (see Figure 4.1). The top 3 samples were combined to give one surface layer abundance estimate, designated as a "pooled sample". For each Alexandrium abundance measurement, $2 \mathrm{~L}$ from each depth was sieved onto a $20 \mu \mathrm{m}$-mesh Nitex screen, and the phytoplankton retained on the screen was back-washed and preserved in 5\% borate buffered formalin (v/v) in $15 \mathrm{ml}$ centrifuge tubes. All cell samples were stored in the dark at $4{ }^{\circ} \mathrm{C}$ until analyses. In addition, samples were collected to determine dissolved organic and inorganic nitrogen at $1,3.5,7,10$ and $20 \mathrm{~m}$, respectively. Nutrient samples were collected during Cruises $1,2,4,6,8,10$, and 11 (see Table 4.2). These samples were filtered and frozen until analysis.

Samples for Alexandrium toxin content and composition were collected at 4 stations along each transect, evenly distributed from inshore to offshore (indicated by the boxes around the station locations in Figure 4.1). Seawater was collected at a depth of approximately $0.5 \mathrm{~m}$ (surface layer) using the combination of the ship's seawater deck hose and hoses connected to two Little Giant submersible pumps. At the selected stations, seawater was passed through a $20 \mu \mathrm{m}$-mesh net hanging over the side of the boat for approximately $30-45$ mins. The flow rate ranged from $26-52 \mathrm{~L} \mathrm{~min}^{-1}$ and was measured at the beginning of each cruise using a calibrated carboy or bucket. An estimated $700-1600 \mathrm{~L}$ of seawater was passed through the $20 \mu \mathrm{m}$ plankton net. Collected material was then back-washed onto a $20 \mu \mathrm{m}$ Nitex sieve and re-suspended into a $50 \mathrm{ml}$ conical centrifuge tube. From the $50 \mathrm{ml}$ sample, $2 \mathrm{ml}$ were removed for cell counts and diluted to $14 \mathrm{ml}$ with filtered seawater into a $15 \mathrm{ml}$ centrifuge tube and preserved using buffered 
Table 4.2. List of cruises in Casco Bay, Maine and samples collected during the 1998 ECOHAB-GOM field season.

\begin{tabular}{|c|c|c|c|c|c|c|c|c|}
\hline \multirow[b]{2}{*}{$\begin{array}{c}\text { Cruises } \\
1998\end{array}$} & \multirow[b]{2}{*}{ Dates } & \multirow[b]{2}{*}{ Julian Days } & \multirow[b]{2}{*}{ Transect } & \multicolumn{5}{|c|}{ Samples } \\
\hline & & & & $\mathrm{N}^{\dagger}$ & Toxin & $\mathrm{T}^{*}$ & $\mathrm{~S}^{\ddagger}$ & Cells \\
\hline 98CB01 & April 6-9 & $103-104$ & $B \& D$ & $\checkmark$ & $\checkmark$ & $\checkmark$ & $\checkmark$ & $\checkmark$ \\
\hline $98 \mathrm{CB} 02$ & April $21-23$ & $111-113$ & $B \& D$ & $\checkmark$ & $\checkmark$ & $\checkmark$ & $\checkmark$ & $\checkmark$ \\
\hline 98CB03 & April 29-30 & $119-120$ & $B \& D$ & & $\checkmark$ & $\checkmark$ & $\checkmark$ & $\checkmark$ \\
\hline 98CB04 & May 4-5 & $124-125$ & B \& D & $\checkmark$ & $\checkmark$ & $\checkmark$ & $\checkmark$ & $\checkmark$ \\
\hline $98 \mathrm{CB} 05$ & May 14 & 134 & $\mathrm{D}$ & & $\checkmark$ & $\checkmark$ & $\checkmark$ & $\checkmark$ \\
\hline 98CB06 & May 18-19 & $138-139$ & B \& D & $\checkmark$ & $\checkmark$ & $\checkmark$ & $\checkmark$ & $\checkmark$ \\
\hline 98CB07 & May 27-28 & $147-148$ & $B \& D$ & & $\checkmark$ & $\checkmark$ & $\checkmark$ & $\checkmark$ \\
\hline 98CB08 & June 2-4 & $153-155$ & $B \& D$ & $\checkmark$ & $\checkmark$ & $\checkmark$ & $\checkmark$ & $\checkmark$ \\
\hline 98CB09 & June $10-11$ & $161-162$ & $B \& D$ & & $\checkmark$ & $\checkmark$ & $\checkmark$ & $\checkmark$ \\
\hline $98 \mathrm{CB} 10$ & June 17-19 & $168-170$ & $B \& D$ & $\checkmark$ & $\checkmark$ & $\checkmark$ & $\checkmark$ & $\checkmark$ \\
\hline $98 \mathrm{CB} 11$ & June $29-30$ & $180-181$ & $B \& D$ & $\checkmark$ & $\checkmark$ & $\checkmark$ & $\checkmark$ & $\checkmark$ \\
\hline $\begin{array}{l}\text { Nutrients } \\
\text { Temperatu } \\
\text { Salinity (ps } \\
\mathrm{OIN}=\mathrm{NO}_{3}^{-}\end{array}$ & $\begin{array}{l}\mathrm{O}_{3}, \mathrm{PO}_{4}^{3-}, \mathrm{N} \\
\left({ }^{\circ} \mathrm{C}\right) \\
\mathrm{O}_{2}^{-}+\mathrm{NH}_{4}^{+}\end{array}$ & $\mathrm{ON}, \mathrm{DIN}, \mathrm{Si}$ & & & & & & \\
\hline
\end{tabular}


formalin, $5 \%$ final concentration $(\mathrm{v} / \mathrm{v})$. The remaining $48 \mathrm{ml}$ was split into two fractions (24 ml each). The first fraction was sieved through a series of sequential meshes of 100 , 64 and $20 \mu \mathrm{m}$, to obtain the plankton fractions: $>100 \mu \mathrm{m}, 100-64 \mu \mathrm{m}$, and $64-20 \mu \mathrm{m}$. The $>100 \mu \mathrm{m}$ fraction was discarded, the $100-64 \mu \mathrm{m}$ and $64-20 \mu \mathrm{m}$ fractions were resuspended with filtered seawater and filtered onto $47 \mathrm{~mm}$ Whatman (934-AH) glass fiber filters. The 100-64 $\mu \mathrm{m}$ and $64-20 \mu \mathrm{m}$ filter fractions were then folded carefully and placed into pre-weighed $15 \mathrm{ml}$ centrifuge tubes containing $2 \mathrm{ml} 0.1 \mathrm{M}$ hydrochloric acid ( $\mathrm{HCl})$ and $2 \mathrm{ml} 0.5 \mathrm{M}$ acetic acid (HOAc), respectively. The other $24 \mathrm{ml}$ of the original plankton sample was filtered directly onto a Whatman $47 \mathrm{~mm}$ filter and placed into a preweighed $15 \mathrm{ml}$ centrifuge tube containing $2 \mathrm{ml} 0.1 \mathrm{M} \mathrm{HCL}$. All $15 \mathrm{ml}$ centrifuge tubes containing filters were frozen until analysis. Only the results of the $0.5 \mathrm{M}$ HOAc (64-20 $\mu \mathrm{m}$ fraction) will be discussed here.

In addition to the transect stations, samples were collected from three shore stations during the same time frame - Lumbo's Hole, Cundy's Harbor (D12) and Hen's Cove (Figure 4.1). Sampling from the shore stations took place from April 27 through June 17, 1998. Lumbo's Hole and Hen's Cove were sampled more often than Cundy's Harbor due to the travel constraints. Each shore station was sampled approximately every 2-5 days.

For the shore stations, samples for toxin analysis, specifically toxin composition, were collected using the same method used for the shipboard sampling, but with a few modifications. Briefly, a $20 \mu \mathrm{m}$ plankton net was hung from the side of a floating dock at each station. Most of the net was submerged in the water, except for the opening of the 
plankton net that was attached to the floating dock. A submersible pump (Rule 2000) powered by a 12 volt marine battery pumped surface seawater into the plankton net at approximately $25-27 \mathrm{~L} \mathrm{~min}^{-1}$ for 30-60 min. Between $700-1550 \mathrm{~L}$ of water were filtered at each station. Afterwards, the $20 \mu \mathrm{m}$ plankton sample was re-suspended into $500 \mathrm{ml}$ and sieved sequentially through 100,64 and $20 \mu \mathrm{m}$ mesh sieves. The $>100 \mu \mathrm{m}$ fraction was discarded and the 100-64 $\mu \mathrm{m}$ and $64-20 \mu \mathrm{m}$ fractions were re-suspended with filtered seawater and filtered onto a Whatman $47 \mathrm{~mm}$ filter (934-AH) and placed into preweighed $15 \mathrm{ml}$ centrifuge tubes containing $2 \mathrm{ml} 0.5 \mathrm{M}$ HOAc, respectively. All toxin samples were frozen until analysis. To determine the ambient Alexandrium cell concentration at each station, $8 \mathrm{~L}$ of surface seawater were collected and filtered onto a $20 \mu \mathrm{m}$ sieve. Each sample was back-washed into a $15 \mathrm{ml}$ centrifuge tube to a final volume of 14 $\mathrm{ml}$ and preserved with borate-buffered formalin (5\% final concentration; $\mathrm{v} / \mathrm{v}$ ).

Alexandrium fundyense quantification. Cell abundance was determined using an immunofluorescence labeling protocol with a monoclonal antibody (MAb) probe. The antibody labeling uses an Alexandrium sp. MAb M-8751-1 (Adachi et al. 1993; Sako et al. 1993), that has been shown to cross-react with $A$. fundyense isolates from the Gulf of Maine. Recently, it has been shown that antibody-labeling variability due to environmental conditions (physiological changes) is minimal and that accurate manual counts are possible despite expected changes in nutrition through time (Anderson et al. 1999).

Labeling protocols for Alexandrium sp. using immunofluorescence have been described previously (Anderson et al. 1999; Turner et al. 2000), but the method was re- 
cently modified as described here. To positively label the Alexandrium cell surface with the M-8751-1 MAb, a Promega Vac-Man filtration manifold (\#A7231) with one-way Luer-Lok stopcocks (A7261) was used with $25 \mathrm{~mm}$ Gelman syringe filter holder screens and $25 \mathrm{~mm}$ centrifuge tube chimneys (handmade). The filtration rig can process up to 14 field samples at a time. After wetting each filter screen with distilled water, a $25 \mathrm{~mm}$ Whatman Cyclopore polycarbonate, clear track-etched membrane filter $(5.0 \mu \mathrm{m})$ was placed on each screen while applying a low vacuum. Afterwards an o-ring was placed onto the filter and the filter chimney was carefully screwed into place. A $0.5-7.4 \mathrm{ml}$ aliquot of a preserved field sample for Alexandrium counts was placed onto a filter, such that each aliquot of concentrated field sample contained the equivalent of 1 or more liters of filtered seawater. A vacuum was applied to near dryness, afterwards $1 \mathrm{ml}$ of $5 \%$ normal goat serum (NGS; Sigma Chemical Co.) in $0.02 \mathrm{M}$ phosphate buffered saline (PBS) was added to each filter and incubated for $30 \mathrm{~min}$ at $25^{\circ} \mathrm{C}$ (room temperature) in dim light. By minimizing light exposure the integrity of the chlorophyll is maintained. Samples were then placed under a vacuum to near dryness, and $300 \mu \mathrm{l}$ of primary antibody (MAb; M-8751-1), diluted 1:50 (v/v with 5\% NGS/PBS) was added to each filter. After a $30 \mathrm{~min}$ incubation at room temperature, each filter chimney was washed three times with $5 \mathrm{ml} 0.5 \% \mathrm{NGS}$ in $0.02 \mathrm{M}$ PBS while under gentle vacuum to near dryness. The filters were then incubated for another 30 min with a goat anti-mouse IgG secondary antibody conjugated to fluorecein isothiocyanate (GAM-FITC; Molecular Probes, Inc.) diluted 1:300 (v/v with 5\% NGS/PBS). The stained filter samples were washed three more times with $5 \mathrm{ml} 0.5 \%$ NGS/PBS while under a vacuum to near dryness. The filter chim- 
neys were removed while applying a vacuum, and each filter was placed onto a glass microscope slide. Between 25-30 $\mu$ of $80 \%$ glycerol in PBS was added to the surface of each cover slip onto the filter. All filter slides were stored in the dark at $4{ }^{\circ} \mathrm{C}$ until counting (maximum 4 days).

The slides were examined using a epifluorescence Zeiss Axioskop equipped with a FITC filter set $($ excitation $=$ BP 450-490, emission $=$ LP 520) at $100 \mathrm{x}$. The entire area of the cover-slip was enumerated for the presence of Alexandrium cells (stained bright green). Cells were only enumerated if a cell was positively labeled with FITC green fluorescence, indicative of the species-specific MAb, and contained natural red fluorescence, indicative of chlorophyll. Positive control samples were run simultaneously using preserved cultured Alexandrium cells to ensure that the cells were stained uniformly.

Nutrient Analysis. Frozen nutrient samples were analyzed for dissolved inorganic nutrients, specifically, nitrate, nitrite, ammonia, phosphate and silicate using a Lachat Autoanalyzer following standard methods (Lachat 1993; Lachat 1994a; Lachat 1994b; Lachat 1994c). Total dissolved N (TDN) was determined following Valderrama (1981) using a Lachat Analyzer. Dissolved organic N (DON) was determined by the difference of the total inorganic nitrogen (DIN) from the total dissolved N (TDN).

Culture Controls. Prior to the field season, during the fall of 1997, Alexandrium strains from Casco Bay, Maine were isolated from germinated cysts and rendered clonal in the laboratory. For comparison to the toxin data from Casco Bay, the toxin content and 
composition of 6 different Casco Bay isolates was determined. The cultures were grown in triplicate $25 \mathrm{ml}$ volumes of $\mathrm{f} / 2$ medium (Guillard 1975), made with $0.2 \mu \mathrm{m}$-filtered Vineyard Sound seawater (VSW). The $\mathrm{f} / 2$ medium was modified by adding $\mathrm{H}_{2} \mathrm{SeO}_{3}$ and reducing the concentration of $\mathrm{CuSO}_{4} \cdot 5 \mathrm{H}_{2} \mathrm{O}$ to a final concentration of $10^{-8} \mathrm{M}$. The cultures were incubated at $15^{\circ} \mathrm{C}$ using an irradiance of $200 \mu \mathrm{mol}$ quanta $\mathrm{m}^{-1} \mathrm{~s}^{-2}$ on a $14 \mathrm{~h}: 10 \mathrm{~h}$ light:dark cycle using fluorescent lamps.

Once the cultures reached mid-exponential growth as monitored by cell abundance and fluorescence during nutrient replete conditions, the cultures were harvested for cell density and toxin determinations. From each culture, three $1.5 \mathrm{ml}$ cell count samples were removed and preserved with Utermohl's solution (Utermöhl 1958). Cell concentrations were determined by counting at least 400 cells per sample in a Sedgewick-Rafter counting chamber. A $15 \mathrm{ml}$ sample for toxin extraction was removed and placed into a pre-weighed, polypropylene $15 \mathrm{ml}$ centrifuge tube and centrifuged (5000 g, $5 \mathrm{~min}, 23$ ${ }^{\circ} \mathrm{C}$ ), the supernatant aspirated, and $500 \mu \mathrm{l}$ of 0.5 Acetic acid (HOAc) was added to each cell pellet.

Toxin Extraction and Analyses. Toxins were extracted by thawing the frozen HOAc field samples and sonifying both types of samples (field and cultured) with a Branson sonic cell disruptor for $20 \mathrm{~s}$ at a setting of $6 \mathrm{~A}$ while the samples were suspended in an ice-water bath. Afterwards, each sample weighed and centrifuged (5000 g, $\left.5 \mathrm{~min}, 25^{\circ} \mathrm{C}\right)$. The total weight of the toxin sample, required to determine the toxin extraction volume, was calculated by substracting the final sample weight from the initial $15 \mathrm{ml}$ tube weight. 
For the field samples only, $1 \mathrm{ml}$ of supernatant was passed through a Millipore, Sep-Pak C18 cartridge following the manufacturer's recommendations. The column eluent was then spun in a Millipore $10,000 \mathrm{MW}$ cutoff filter at $4000 \mathrm{~g}$ for $5 \mathrm{~min}$. From the purified field samples and the centrifuged cultured cell extracts, approximately $200 \mu$ from each was loaded into separate auto-sampler vials, and analyzed for saxitoxins by HPLC using the three-step isocratic elution method of Oshima et al. (1989) following the modifications of Anderson et al. (1994). The total toxin extraction volume for the field samples was calculated as follows:

toxin extraction $w t .(T E W)=($ final sample $w t .-$ tube tare $w t .-$ filter $w t$.

$$
\text { Vol.of SW\& a } \lg a e=\frac{(T E W-\text { acid wt. })}{d}
$$

Toxin extraction Vol. $(T E V)=($ Vol. of $S W+$ alg ae $)+$ acid Vol.

where the weights (wt.) are in $\mathrm{kg}$ and volumes (Vol.) represented in $\mathrm{L}$, the filter weight is the dry weight in $\mathrm{kg}$ and $d$ represents the density of seawater $(S W)$. To determine the ambient toxin concentration in the seawater surface layer at each station as shown in Figure 4.2 , the following equation was used:

$$
\text { pmol toxin } L^{-1}=\frac{[T] \bullet T E V}{V_{s W}}
$$

where $[T]$ is the toxin concentration as determined by the HPLC in pM, TEV is the total toxin extraction volume as described previously, and $V_{\mathrm{SW}}$ is the volume of ambient surface seawater that was collected and filtered for toxin extraction. The toxin abbreviations 
used throughout this paper are: STX, saxitoxin; NEO, neosaxitoxin; GTX 1,4, gonyautoxins 1 and 4; GTX 2,3, gonyautoxins 2 and 3; GTX 5, gonyautoxin 5; GTX 6, gonyautoxin 6; $\mathrm{C} 1,2$, toxin $\mathrm{C} 1$ and $\mathrm{C} 2$. To determine whether toxin composition (mole percent total toxin) changes significantly through time and distance from shore, a two-way ANOVA was performed for each derivative of the two different transects (B vs. D - considered replicates) as a factor of time (cruise) and distance (station). Tukey's multiple comparison test was used to determine differences among individual times and stations. 


\section{RESULTS}

Alexandrium distributions. Alexandrium fundyense was detected in the water column during all 11 cruises taken in the Casco Bay region from April to June of 1998 (Figures $4.2 \& 4.3$ ). There were only a few stations during the last cruise in late June where $A$. fundyense was considered undetectable (detection limit $=1$ cell $\mathrm{L}^{-1}$ ). Alexandrium fundyense cell concentrations fluctuated through time, with considerable variability between stations. At the beginning of the field season in early April, cell abundance was low (between 1-50 cells $\mathrm{L}^{-1}$ ). In late-April, the cell abundance increased rapidly at both the inshore and offshore stations. At all stations, the cell distribution was either bimodal with peaks in early May and mid-June, or evidenced a single, broader peak between May and June, declining thereafter. For almost all shipboard and shore stations the bloom reached a maximum density in the middle of May. At the transect toxin sampling sta-

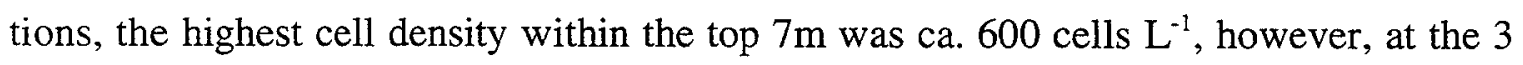
shore stations, the cell abundance attained much higher cell densities (approximately $2500-4000$ cells $L^{-1}$ ). The large differences are most likely caused by the difference in sampling methods, the shore counts were from a single surface sample, whereas the shipboard station counts were from a pooled sample representing 4 depths. Overall, the cell concentrations at the inshore stations (both shipboard and onshore) appeared to have higher cell numbers at the peak of the bloom with an additional peak in cell abundance occurring in mid-June (Figure 4.2 Station B12 and D12). 
FIGURE 4.2. Surface toxin concentrations and Alexandrium fundyense cell abundance at shipboard stations (D1, D5, D8, D12 \& B3, B6, B9, B12) during the 1998 field season. The (-) black lines represent the $A$. fundyense concentration from a seawater sample that was pooled from $1,3.5$, and $7 \mathrm{~m}$, whereas the ( $\mathbf{\square})$ red lines represent surface cell concentrations determined from an aliquot removed from a pumped toxin sample at each shipboard station. Using the secondary y axis, the green lines $(\mathbf{A})$ represents the calculated total toxin concentration (pmol toxin $\mathrm{L}^{-1}$ ) in the surface seawater from each shipboard station. Both the cell and toxin cell concentrations in the surface seawater correlated well, demonstrating the strong association of $A$. fundyense with toxin distribution, as expected. 

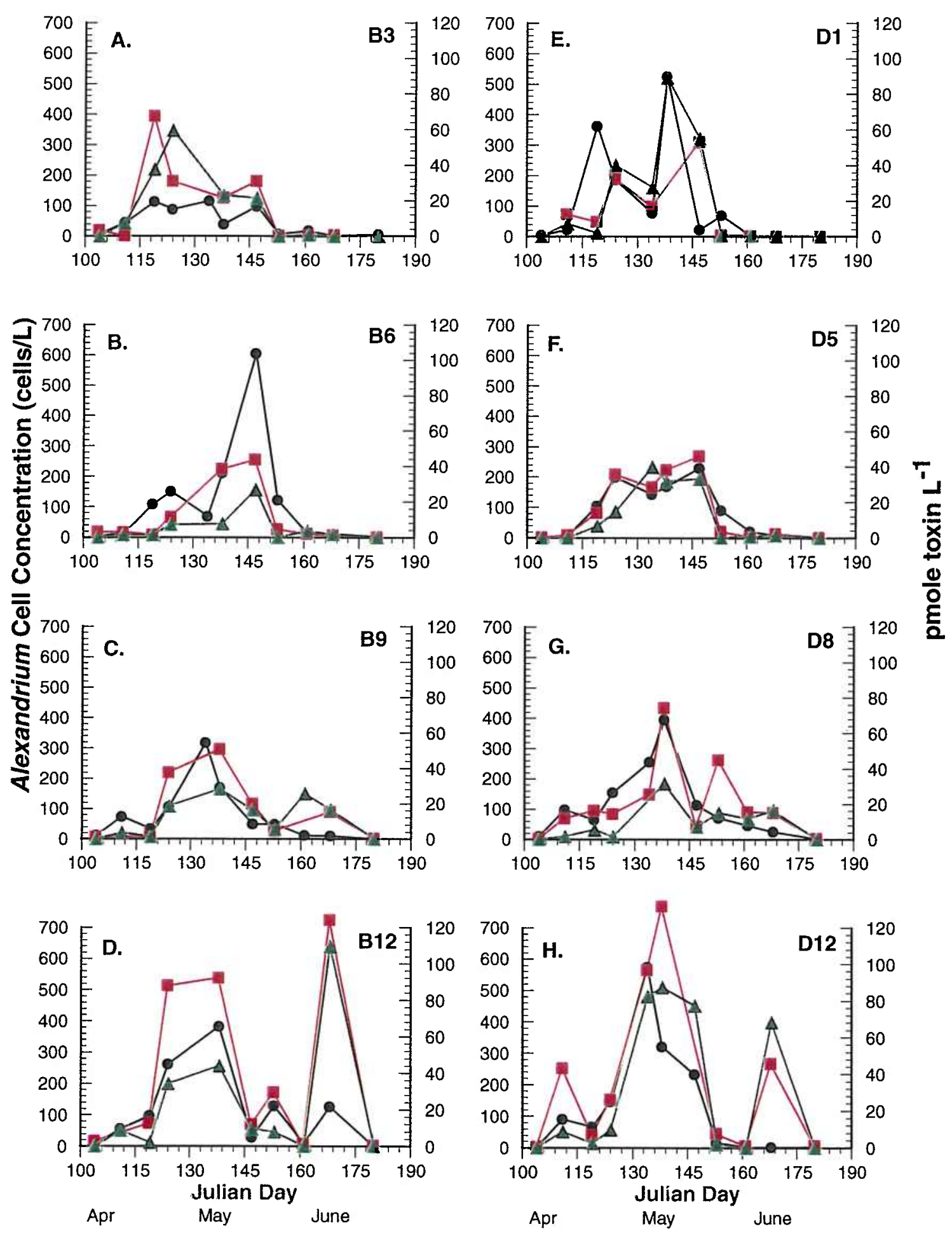
FIGURE 4.3. Surface toxin concentrations and Alexandrium fundyense cell abundance at 3 shore stations during the 1998 field season. The ( black lines) represent cell concentrations determined for discrete surface $(1 \mathrm{~m})$ seawater samples. Using the secondary $y$ axis, the green lines $(\mathbf{A})$ represent the calculated total toxin concentration (pmol toxin $\left.\mathrm{L}^{-1}\right)$ in the surface seawater from each station. As shown and discussed in Figure 4.2 the cell abundance and toxin concentration in the surface seawater correlate well. 


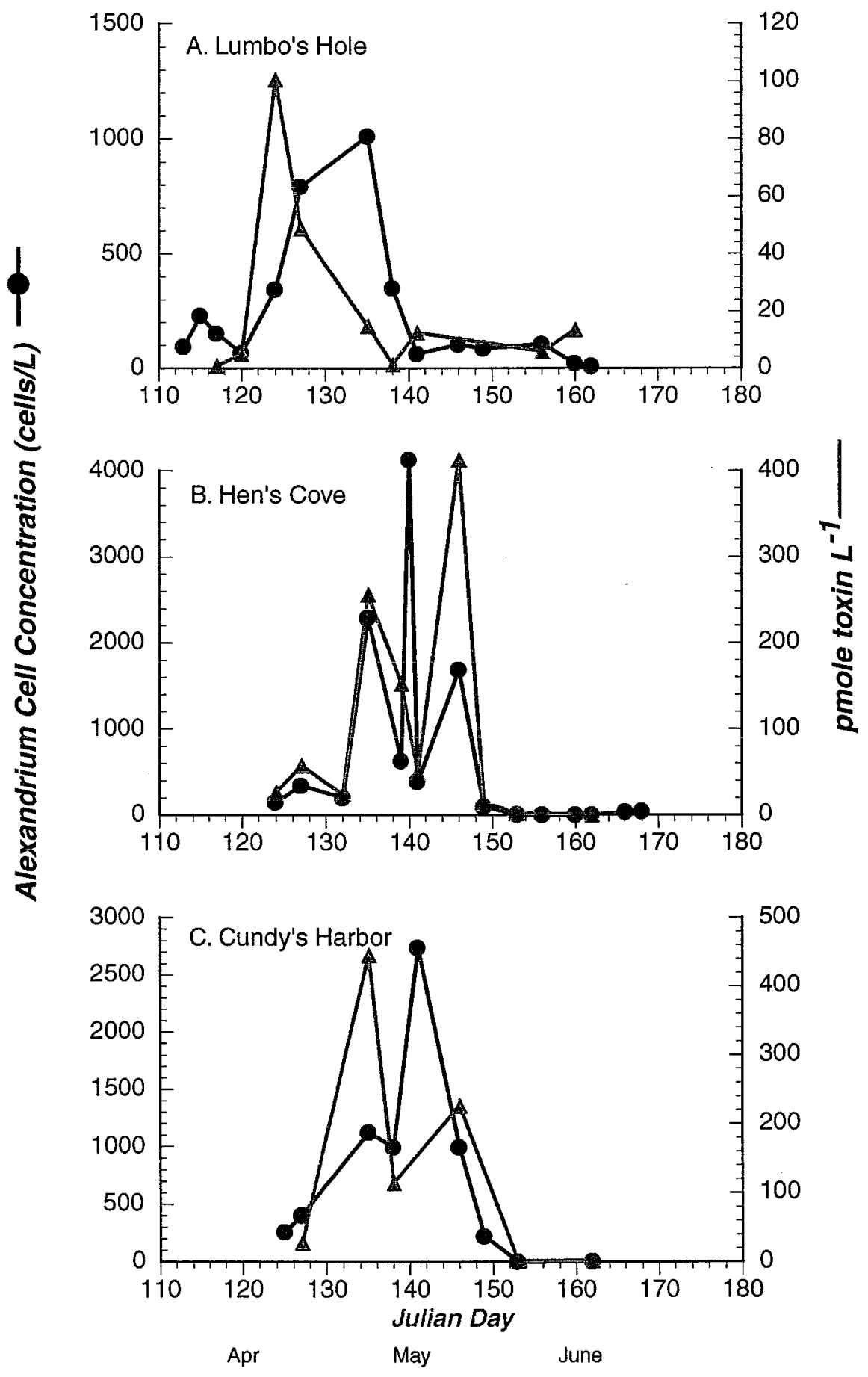


Physical and chemical distributions. The seawater temperature changed significantly over the course of the Casco Bay field season (Figure 4.4 A.). Sea surface temperatures ranged from $4-14{ }^{\circ} \mathrm{C}$ from early April to late June. In mid-April, the water temperature was relatively uniform within the top $25 \mathrm{~m}$, ranging between $4-6^{\circ} \mathrm{C}$. During the latter part of May and into the beginning of June, a warm surface layer $\left(12-14^{\circ} \mathrm{C}\right)$ became apparent within the top $5 \mathrm{~m}$ with a rapid temperature gradient beginning at $7-9 \mathrm{~m}$ with much cooler temperatures $\left(6-10^{\circ} \mathrm{C}\right)$ below $10 \mathrm{~m}$.

Salinity in the surface layer for the B and D transects ranged between 24-31 psu throughout the field season, with an average of 29 psu (Figure 4.4 B.). The highest Alexandrium cell densities were reported within a salinity range of 28-30 psu corresponding to a surface water temperature of $8-11^{\circ} \mathrm{C}$. Lower salinity occurred more frequently at inshore sampling sites along both the B and D transects, which correlates with the large riverine inputs from the Kennebec and Androscoggin Rivers.

Total dissolved inorganic nitrogen (DIN) concentrations changed significantly in the surface layer and vertically, with depth over the course of the field season (Figures $4.5 \& 4.6)$. Initially, high DIN values were reported throughout the water column (7.0 $4.0 \mu \mathrm{M}$ ) during cruise 1 in early April (see Table 4.2 for Cruise Dates). The DIN in the surface layer then declined rapidly over the next two weeks, while maintaining higher concentrations below $7 \mathrm{~m}$. DIN values were low but measurable in surface waters in May $(1.8-0.01 \mu \mathrm{M})$, but were below detection throughout most of the water column during Cruise 8 (June 1-4, 1998) - Figure 4.5 and 4.6. However, during most cruises DIN values were higher $(2-4 \mu \mathrm{M})$ at depths greater than $20 \mathrm{~m}$. During Cruise 10 (June 
$15-19,1998)$ DIN values increased briefly in the surface layer, especially at the inshore stations on the B transect (B9 \& B12) (Figure 4.5). This surface layer nutrient increase (top $7 \mathrm{~m}$ ) was also observed in the ambient phosphate concentrations. The reported increases correlate with a massive freshwater runoff event in the Kennebec River that occurred during a week long period of precipitation at the beginning of June.

Phosphate concentrations ranged between $0.1-1.3 \mu \mathrm{M}$ throughout the field season. In the surface layer, phosphate concentrations ranged from $0.1-0.75 \mu \mathrm{M}$, with the largest values reported during Cruise 1 in early April. At $20 \mathrm{~m}$, phosphate concentrations were between $0.3-1.3 \mu \mathrm{M}$ and at no time during the field season was phosphate undetectable (Figure $4.7 \mathrm{~B}$ ).

$\mathrm{N}: \mathrm{P}$ atomic ratios were calculated for all stations throughout the field season (Figure $4.7 \mathrm{C}$ ) using the concentrations of DIN and phosphate within the top $7 \mathrm{~m}$ (pooled samples) at all stations (Figures 4.7 A \& B). During Cruise 1 in early April, the highest $\mathrm{N}: \mathrm{P}$ ratios ranged from $6-10$, but as the field season progressed, N:P ratios declined rapidly, to between 0 and 6 . As $A$. fundyense concentrations increase throughout the field season the largest cell concentrations are associated with very low DIN (0.5$1.5 \mu \mathrm{M})$, phosphate $(0.2-0.4 \mu \mathrm{M})$ and very low $\mathrm{N}: \mathrm{P}$ ratios (ranging from 2-5; Figure 4.7). 
FIGURE 4.4. Surface Alexandrium abundances vs. temperature (A.) and salinity (B.) averaged over the top $7 \mathrm{~m}$ at each station throughout the field season. Each color represents a different cruise. 


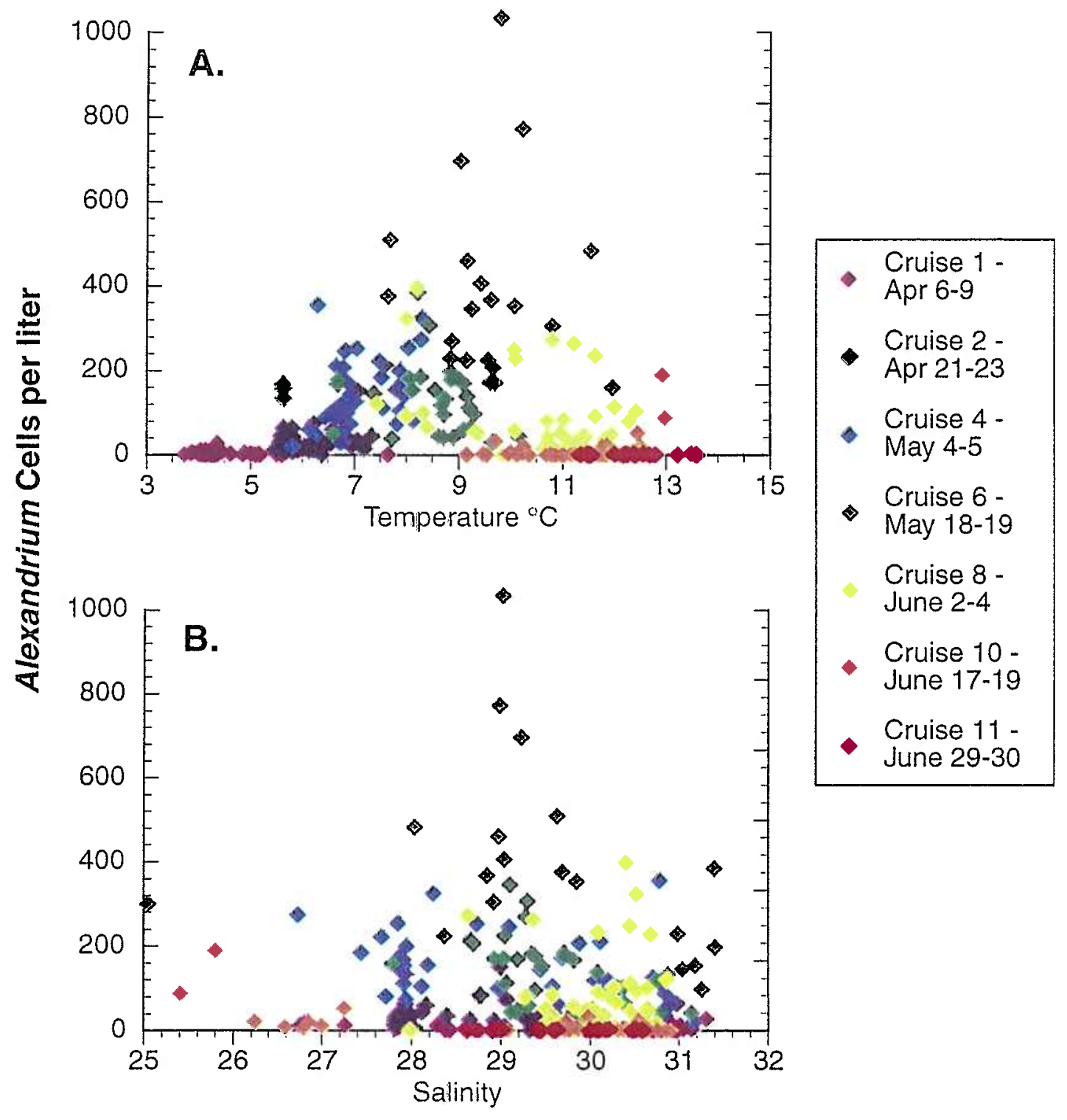


FIGURE 4.5. Changes in sigma $t$ (water density) and DIN at each toxin sampling station throughout the field season along Transect B. DIN concentrations $(\mu \mathrm{M})$ at different depths are superimposed over each contour plot, each dot corresponding to a particular DIN concentration represented by the color bar. Grey dots represent undetectable values. Dark black lines represent the bottom and the changes in depths are due to tidal water movements (A) Station B3, (B) Station B6, (C) Station B9, (D) Station B12. 
B3
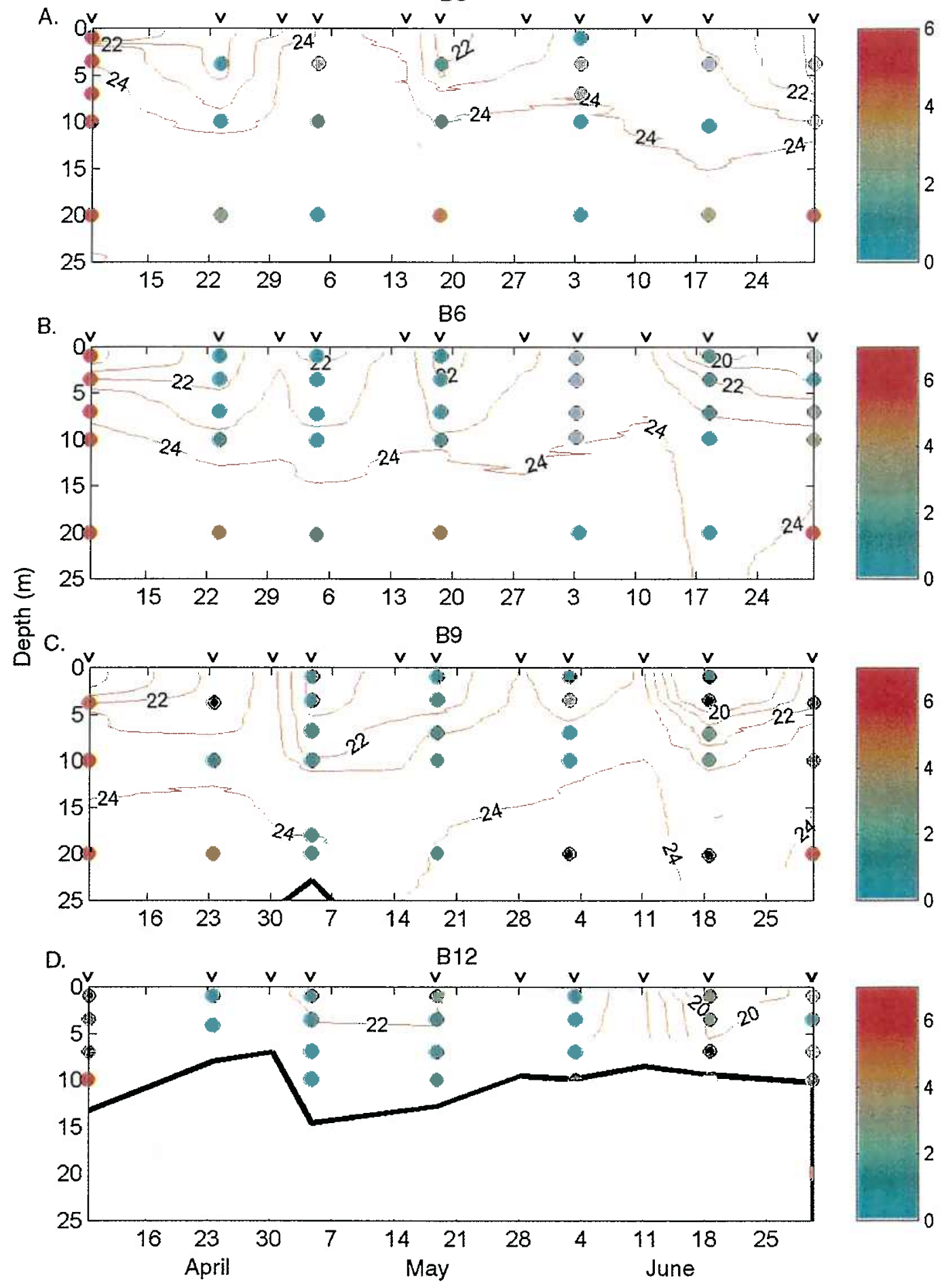
FIGURE 4.6. Changes in sigma $t$ (water density) and DIN at each toxin sampling station throughout the field season along Transect D. DIN concentrations $(\mu \mathrm{M})$ at different depths are superimposed over the contour plot, each dot corresponding to a particular DIN concentration represented by the color bar. Grey dots represent undetectable values. (A) Station D1, (B) Station D5, (C) Station D8, (D) Station D12. 

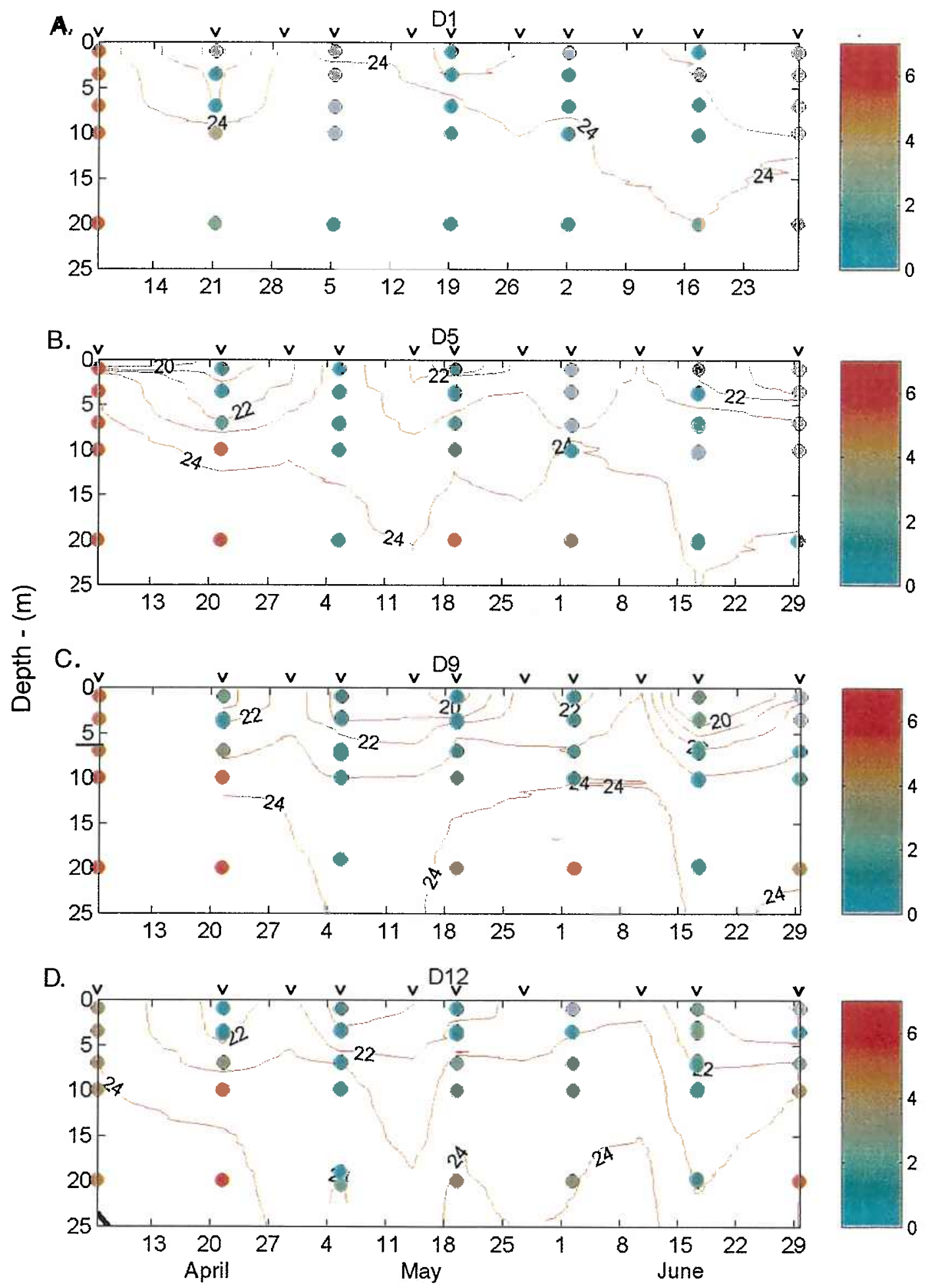
FIGURE 4.7. Surface (top $7 \mathrm{~m}$ ) nutrient concentrations and $\mathrm{N}: \mathrm{P}$ ratios vs. Alexandrium fundyense abundance during the Casco Bay, Maine field season. (A) DIN (B) Phosphate and (C) N:P (atomic ratio). Each color represents a different cruise. 

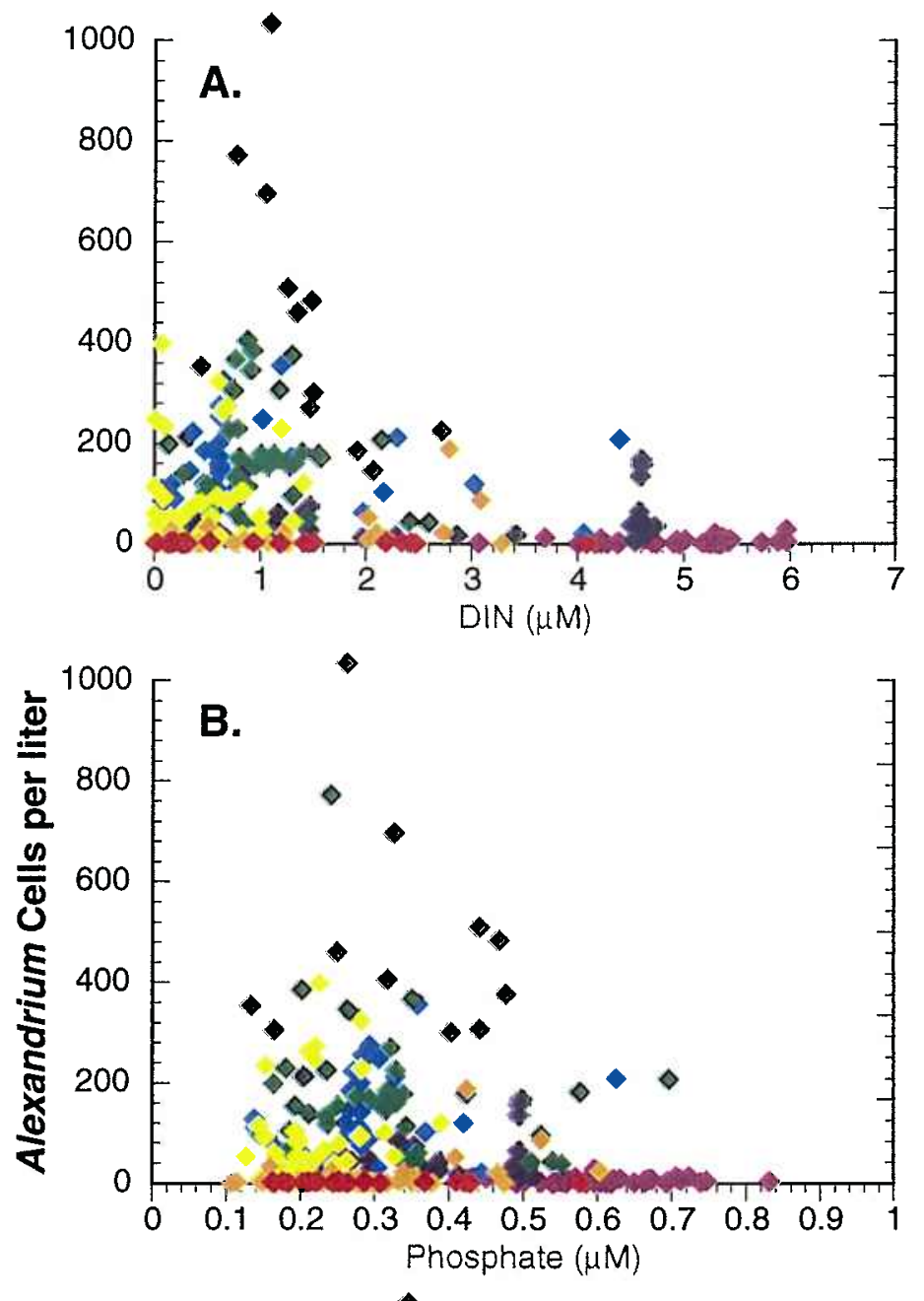

Cruise 1 Apr 6-9

- Cruise 2 Apr 21-23

- Cruise 4 . May 4-5

- Cruise 6 May 18-19

Cruise 8 June 2-4

Cruise 10 June 17-19

- Cruise 11 June 29-30

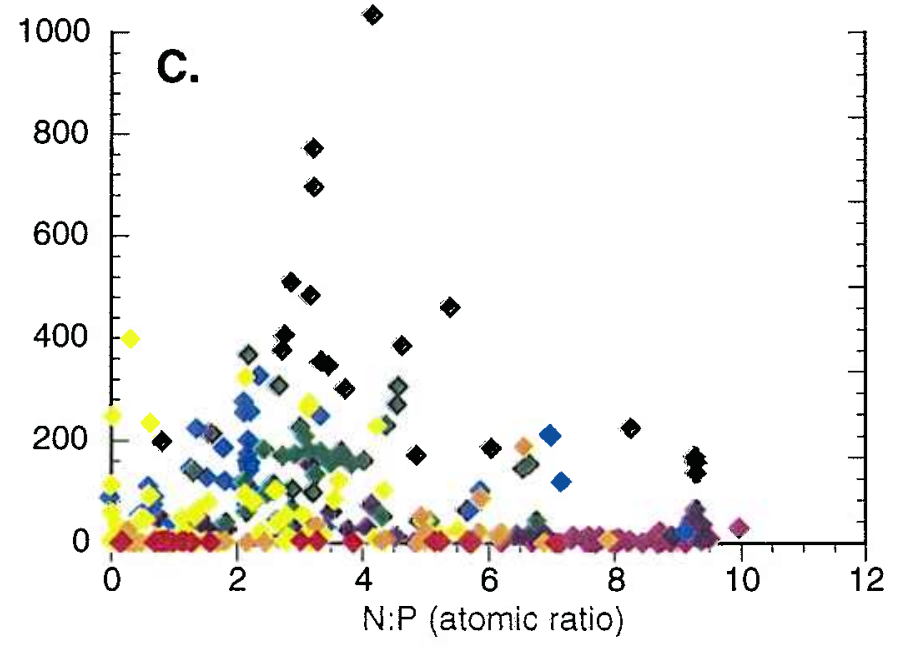


Variations in Toxin Abundance and Content. The $64-20 \mu \mathrm{m}$ size fraction samples that contained Alexandrium fundyense from 8 transect stations and 3 shore stations were assessed for toxin content and composition using HPLC. At each toxin station along the D transect (Stations: D1, D5, D8 \& D12), 11 samples were collected corresponding to all 11 cruises. Along the B transect (Stations: B3, B6, B9 \& B12) 10 toxin samples were collected at each station. At the Lumbo's Hole, Hen's Cove and Cundy's Harbor shore stations, 13, 12 and 8 toxin samples were collected, respectively, from April 17 - June 17, 1998. Of the 117 samples collected, toxin was detectable by HPLC in 93 . Of the 24 samples that contained no toxins, 16 were from early April (6-9 $)$ and late June (29-30 $\left.{ }^{\text {th }}\right)$ when A. fundyense cell abundance was low or undetectable, corresponding to the beginning and end of the field season respectively.

Total toxin concentrations in the surface of the water column (pmol toxin $\mathrm{L}^{-1}$ ) increased and then decreased through time for both the shore and transect samples, mimicking the patterns of $A$. fundyense abundance in the water column as the field season progressed (Figures $4.2 \& 4.3$ ). The cell abundance from each pumped toxin sample along the $\mathrm{B}$ and $\mathrm{D}$ transects correlated well with the ambient cell concentrations determined from the pooled bottle samples (Figure 4.2). The highest toxin concentrations (100-400 pmol STX L $\left.{ }^{-1}\right)$ were reported between May $14-27$ at both the shore and transect stations, whereas, the lowest toxin values $\left(0-10\right.$ pmol STX L $\left.{ }^{-1}\right)$ corresponded to the times at the beginning and end of the field season when $A$. fundyense concentrations were low, but toxin concentrations were still detectable (Figures 4.2 and 4.3). 
Toxin content (fmol cell-1) was calculated at many transect stations (Figure 4.8) using the cell abundance from each toxin sample and the total toxin concentration measured on the HPLC. These values were highly variable, ranging from 36 to 325 fmol cell $^{-1}$. Values were not calculated for stations with low or undetectable cell abundance or toxin concentrations, as occurred for most samples during Cruise 1 (at the beginning of the bloom in early April) and for many samples during Cruises 8, 9 and 10, as the bloom declined in June.

The toxin content (fmol cell ${ }^{-1}$ ) of cultured isolates from Casco Bay (CB-isolates) ranged from $113-155 \mathrm{fmol} \mathrm{cell}^{-1}$ (mean 128), during $\mathrm{N}$-replete conditions (Figure $4.9 \mathrm{~B}$ ). One isolate (CB-301) was also grown under N-limited, semi-continuous conditions and analyzed for toxin composition using HPLC. At extreme levels of N-limitation, growth rate slowed to $0.05 \mathrm{~d}^{-1}$ and cellular toxin content decreased to $33 \mathrm{fmol}$ cell ${ }^{-1}$. 
FIGURE 4.8. Cellular toxin content $\left(\mathrm{fmol} \mathrm{cell}{ }^{-1}\right)$ at different stations over the course of the field season. (A) Transect B, (B) Transect D. 
A.

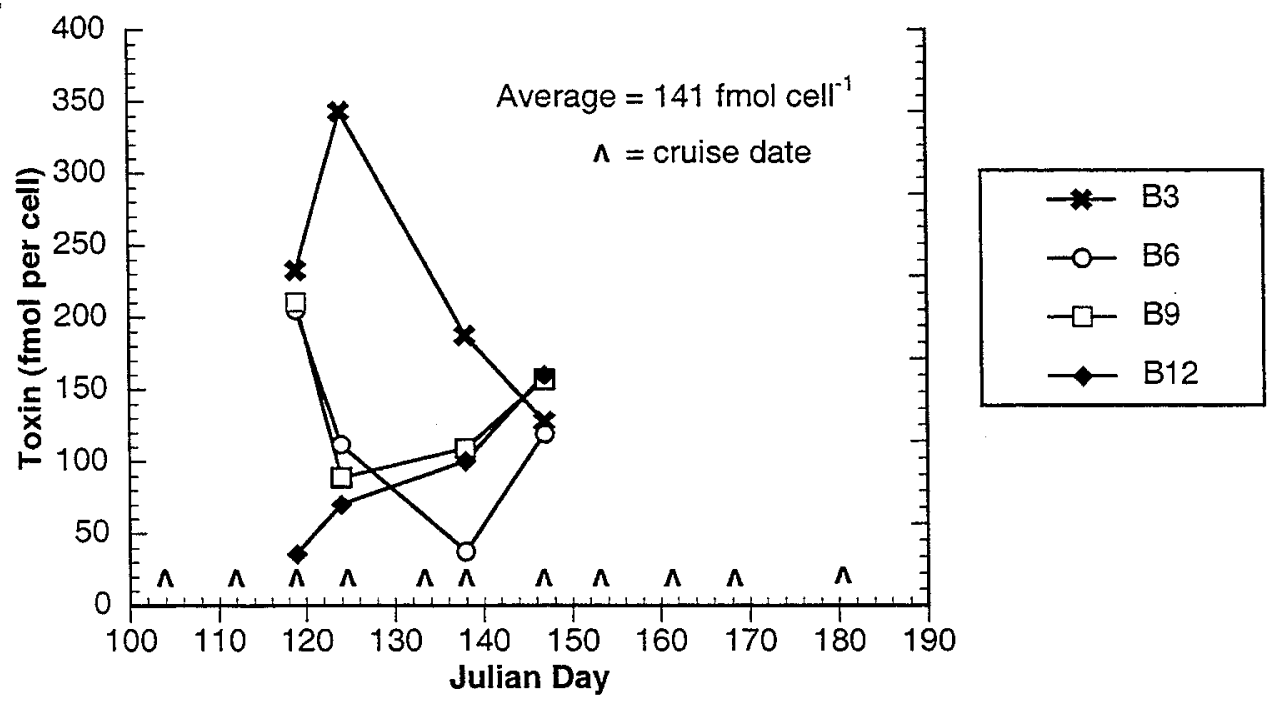

B.

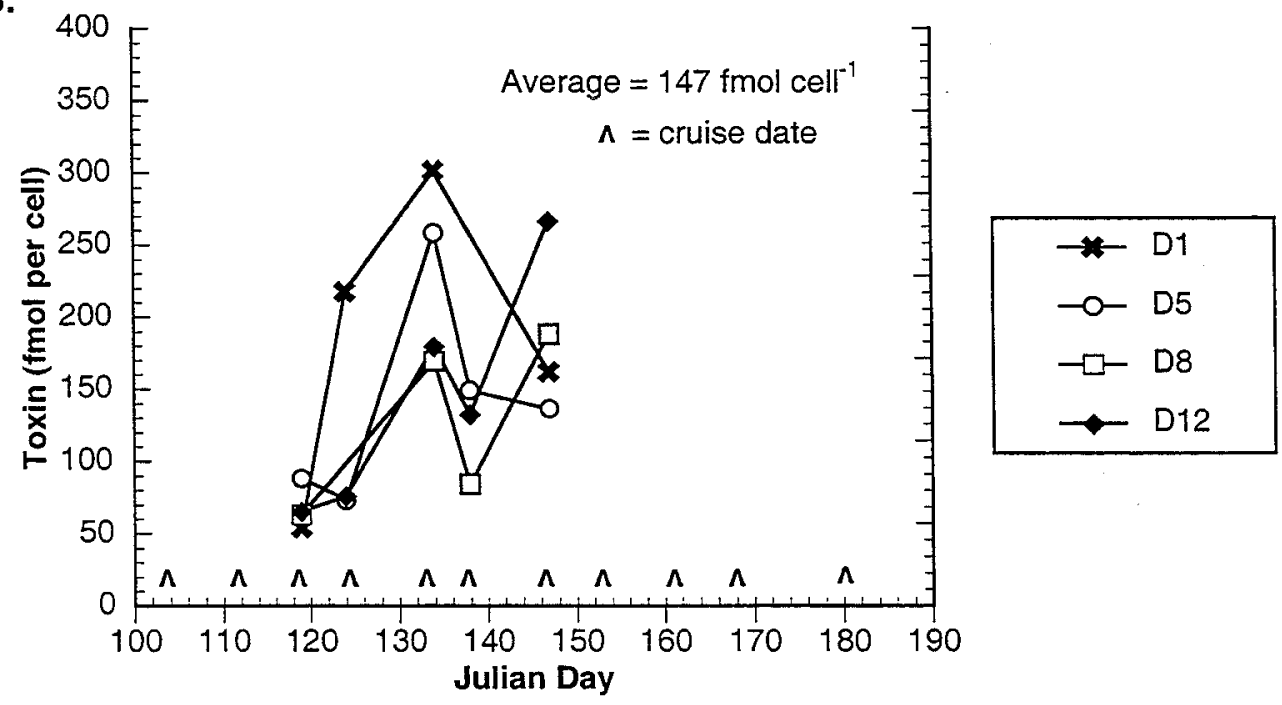


FIGURE 4.9. Toxin content and composition of Casco Bay isolates (CB) and one Gulf of St. Lawrence isolate (ATSL23). (A) relative proportions of different saxitoxin derivatives (mole \% total toxin). (B) cellular toxin content - total and individual STX derivative concentrations ( $\left.\mathrm{fmol} \mathrm{cell}^{-1}\right)$. (C) Toxin ratios of different STX derivatives. 


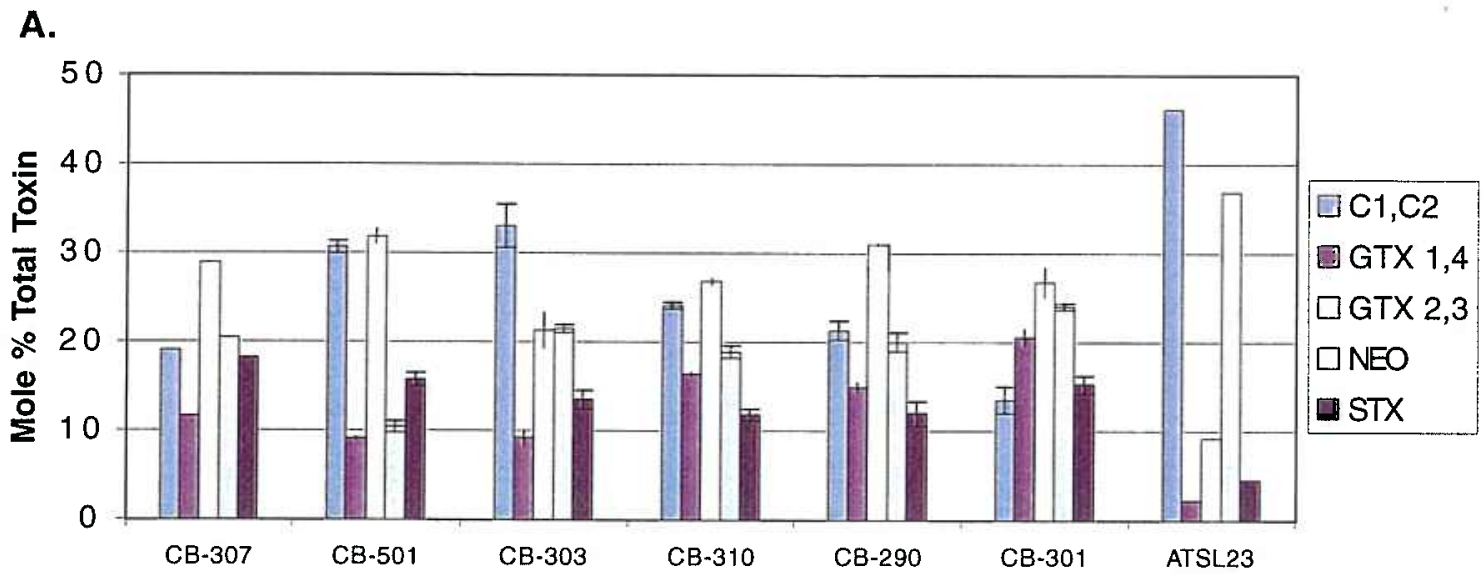

B.

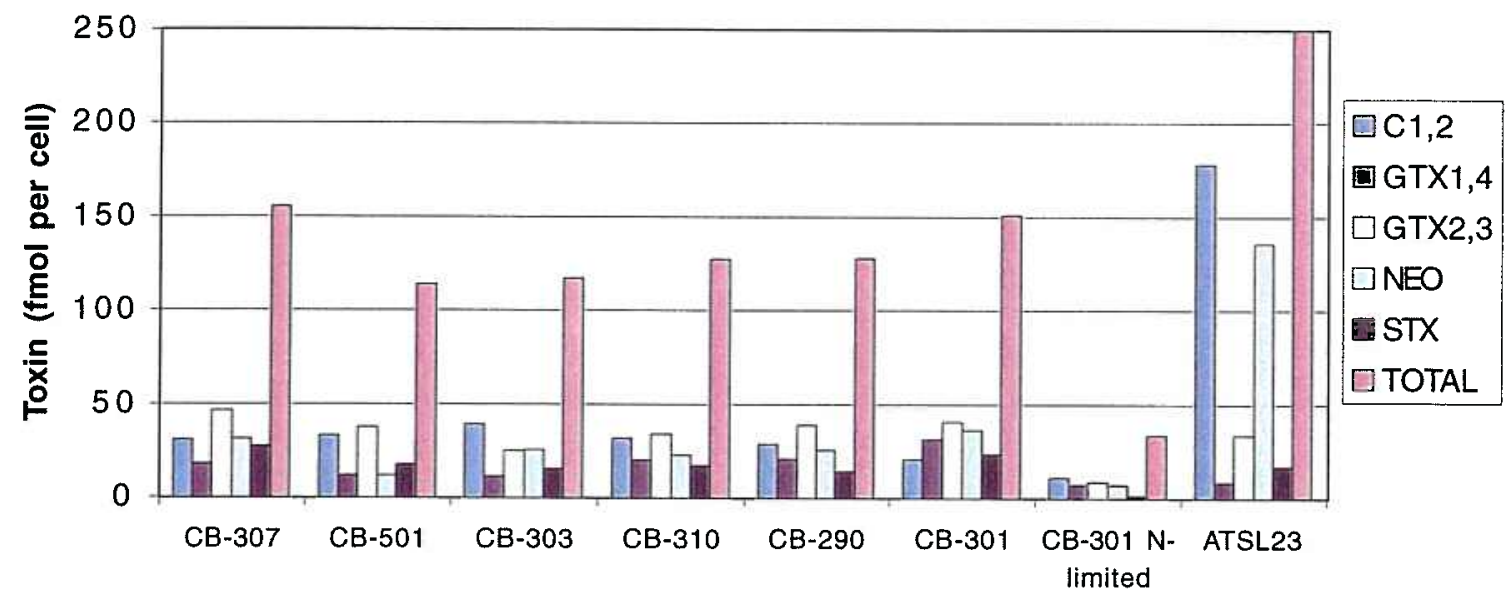

c.

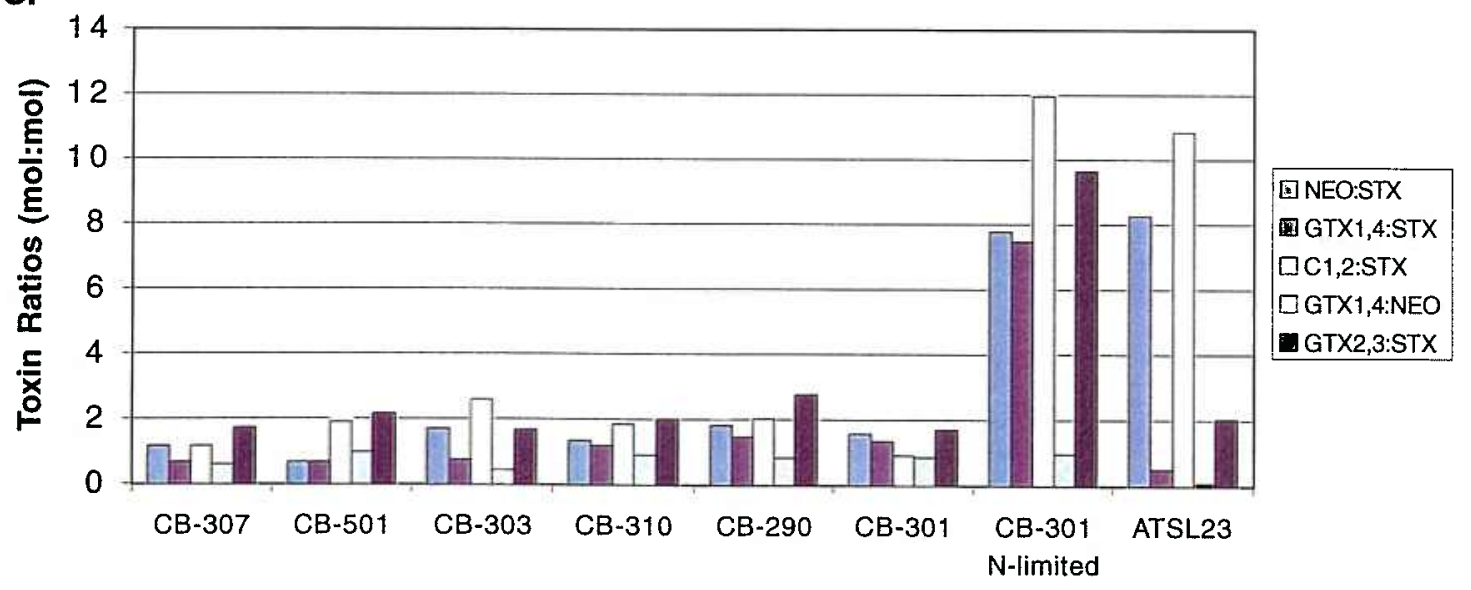


Variations in Toxin Composition. Changes in toxin ratios (mol:mol) and relative proportions (mole percent of total toxin) of the main STX derivatives were used to examine trends over the course of the field season. Of the more than 20 naturally occurring saxitoxins (Oshima 1995), Casco Bay field samples were found to contain 10 different derivatives. The major toxins present (in order of relative abundance as mole $\%$ total toxin) were GTX 3, GTX 4, NEO, STX and C2. Toxins found in minor abundance were GTX 5, GTX 2, GTX 1, C1 and dcGTX3. For interpretation of the compositional analysis, GTX $1 \& 4$, GTX $2 \& 3$ and, C1 \& C2 were grouped together, since the epimeric pairs GTX1/GTX4, GTX2/GTX3, and C1/C2 are subject to rapid interconversions (Oshima et al. 1993).

Over the course of the field season, significant differences in the toxin composition profile were observed in the pumped plankton samples (Figures 4.10, 4.11\& 4.12). In most cases, the relative molar abundance of NEO and STX decreased through time for the shore stations and the transect stations, whereas, GTX 1,4 increased. For example, at station B6, NEO and STX decreased from 28 and 7 to 15 and 0 mole percent, respectively from April 21-23 to June 17-19 whereas, GTX1,4 increased from 30 to 52 mole percent over the same interval. C1,C2 and GTX 2,3 remained relatively constant at the transect stations, but $\mathrm{C} 1, \mathrm{C} 2$ decreased through time (from $15-3$ mole percent; Figure 4.12) at the shore stations (Lumbo's Hole, Hen's Cove and Cundy's Harbor) and GTX 2,3 increased (from 30 - 40 mole percent; Figure 4.12).

For the transect data only, a two-way ANOVA with no interactions between transects B \& D showed significant differences between the averaged means of the relative 
proportions (mole \% of total toxin) of NEO, STX, GTX 1,4, and GTX 2,3 with respect to TIME $(\mathrm{P}<0.001)$ and STATION $(\mathrm{P}<0.001-0.004)$. The two transects were considered as replicates. Prior to performing the two-way ANOVA, the data were transformed using a square root function to full fill the normality requirement of the statistical test. Afterwards, Tukey's multiple comparison test was used to determine whether significant differences were observed between specific Times (cruises) and Stations.

In addition to determining the relative abundances of the different toxins, toxin ratios (mol:mol) of different saxitoxin derivatives were calculated as follows:

$$
\text { Toxin Ratio }\left[T_{A}: T_{B}\right]=\left[\frac{T_{A}}{T_{B}}\right]
$$

where $\left[T_{A}\right]$ is the absolute toxin concentration of derivative $\mathrm{A}(\mu \mathrm{M})$ and $\left[T_{B}\right]$ is the absolute toxin concentration of derivative $B(\mu \mathrm{M})$. Over the course of the field season, significant increases were observed in the following toxin ratios at most stations along transect B and D: GTX1,4:STX, NEO:STX, and GTX2,3:STX (Figures 4.13, and 4.14). For example, over the course of the field season at station D8 (Figures 4.13, C1 \& 2) ratios GTX1,4:STX, NEO:STX, and GTX2,3:STX increased 4-6 fold from 4, 3, and 5 to 26,18, and 11, respectively. However other ratios, such as GTX1,4:NEO, C1,2:STX, and GTX2,3:STX increased but not with the same magnitude. No significant variations were observed in the $\mathrm{C} 1,2 \mathrm{NEO}, \mathrm{C1} 1,2: \mathrm{GTX} 1,4$ and $\mathrm{C1,2:}$ : GTX2,3 ratios. Overall, along the two transects, some ratios differed by a factor of 5 or more, others only 2 or 3 fold. If I compare the inshore stations (B12 and D12) to the offshore stations (B3, B6 and D1, D5) the increase in the GTX1,4:STX and GTX2,3:STX ratios towards the end of June are 
usually larger for the offshore (between 20-50) than the onshore stations (between 1015). At the shore stations (Lumbo's Hole, Hen's Cove and Cundy's Harbor - Figure 4.15) lower magnitudes of the GTX1,4:STX and GTX2,3:STX ratios were also observed. Overall, the magnitudes of the ratios at the shore stations and the inshore stations on the $\mathrm{B}$ and $\mathrm{D}$ transects were similar.

FIGURE 4.10. Relative proportions (mole \% total toxin) of the different STX derivatives at stations along Transect B during cruises (2-10). (A) B3, (B) B6, (C) B9, (D) B12. 

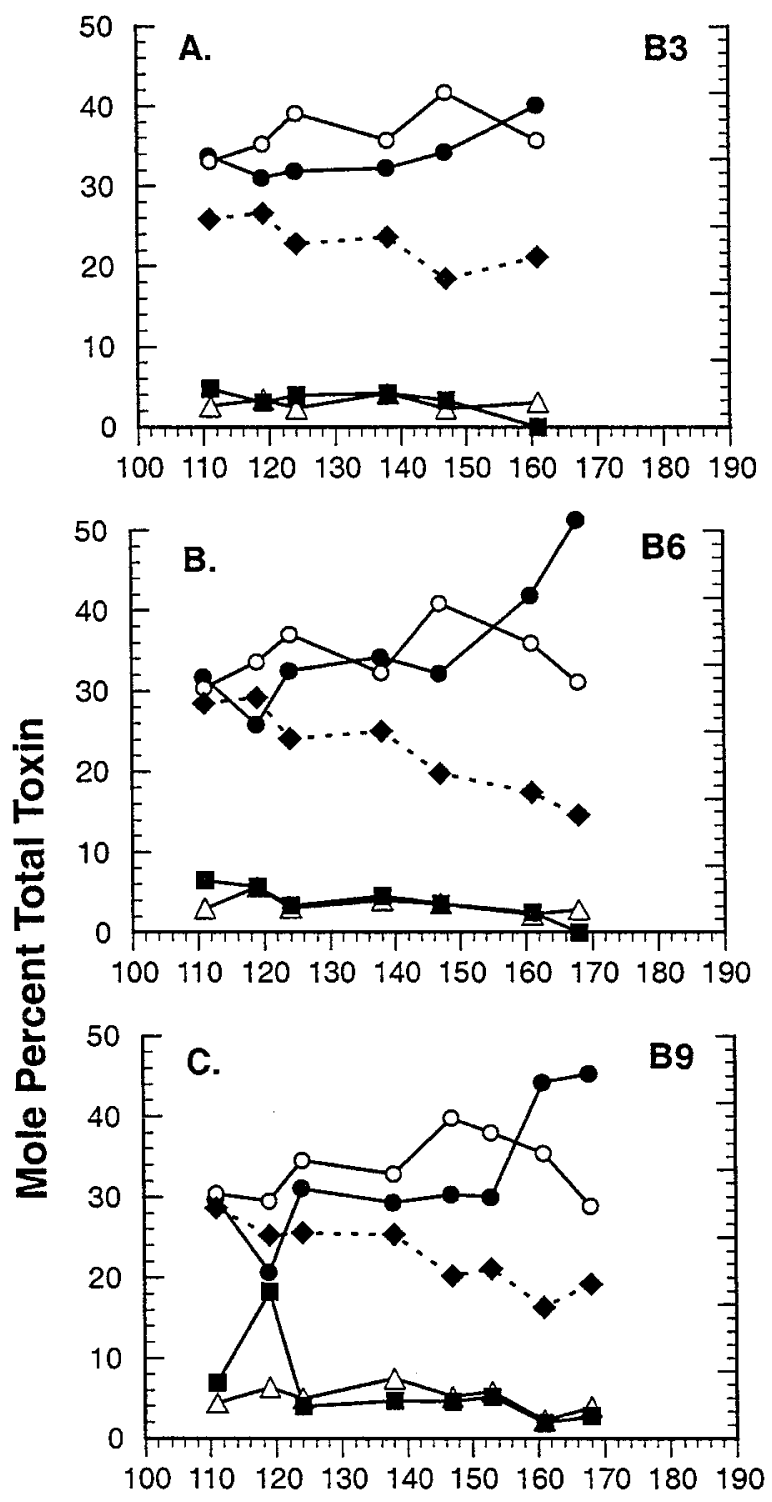

$$
\begin{aligned}
& \rightarrow \text { GTX 1 \& } 4 \\
& \multimap \text { GTX 2 \& } 3 \\
& \rightarrow \text { C1\& } 22 \\
& \rightarrow \text { NEO } \\
& \rightarrow \text { STX }
\end{aligned}
$$

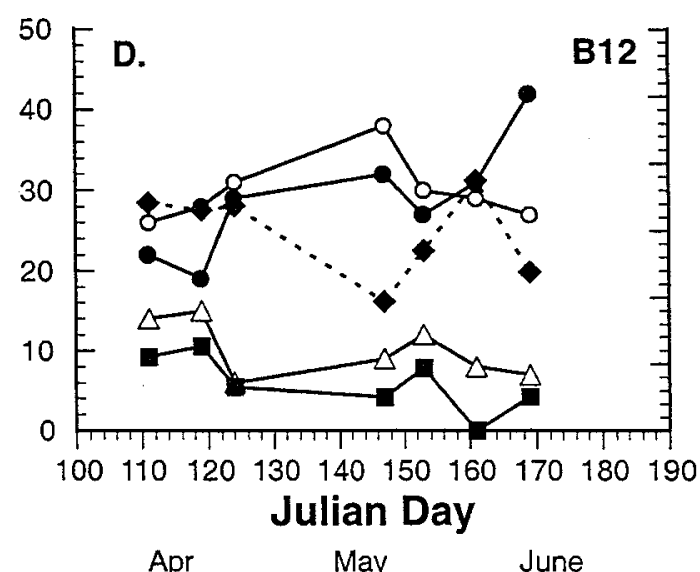


FIGURE 4.11. Relative proportions (mole \% total toxin) of different STX derivatives at stations along Transect D during different cruises (2-10). (A) D1, (B) D5, (C) D8, (D) D12. 

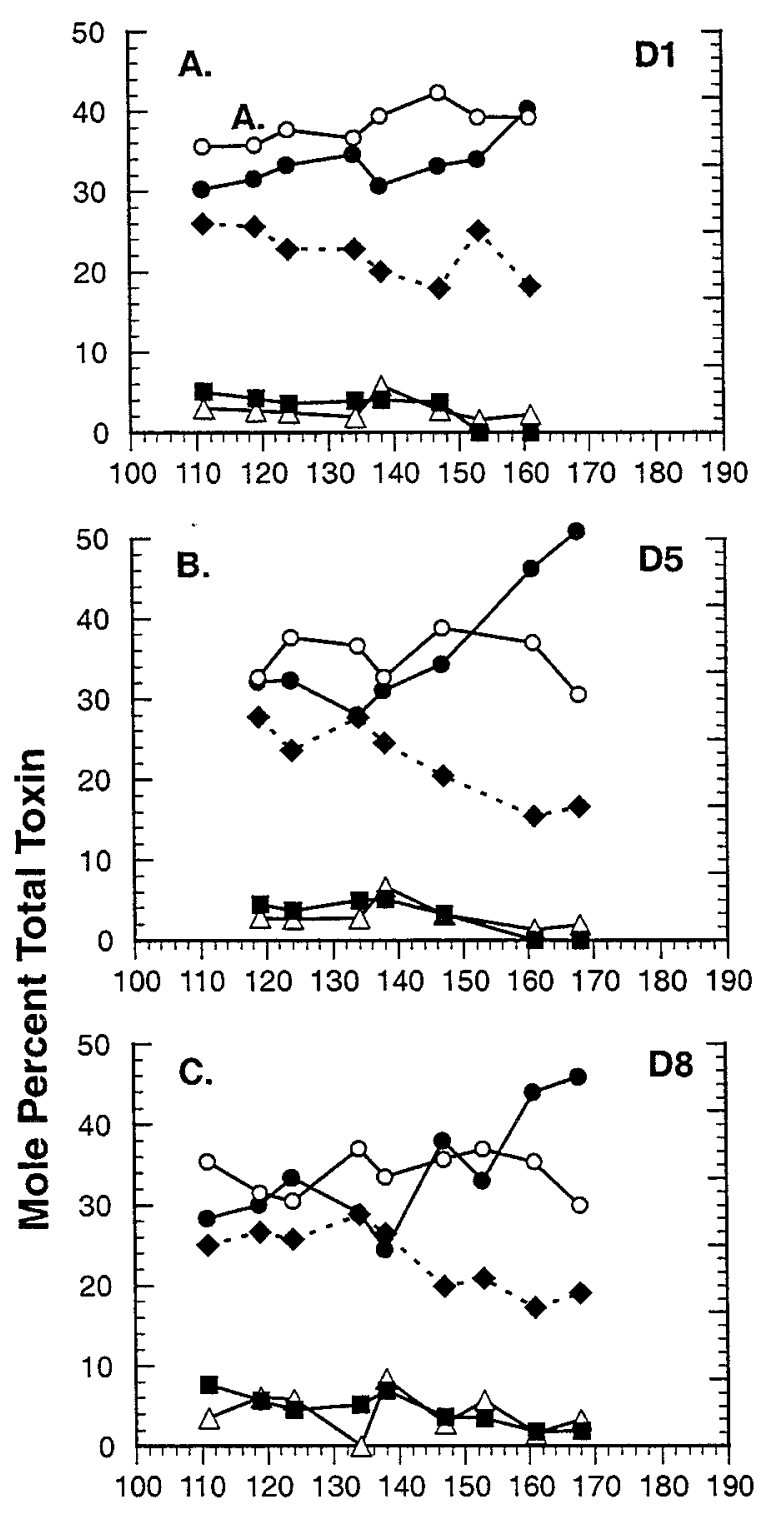

$$
\begin{aligned}
& \rightarrow \text { GTX 1\&4 } \\
& \multimap \text { GTX } 2 \& 3 \\
& \rightarrow \text { C1 \& C2 } \\
& \rightarrow \text { NEO } \\
& \rightarrow \text { STX }
\end{aligned}
$$

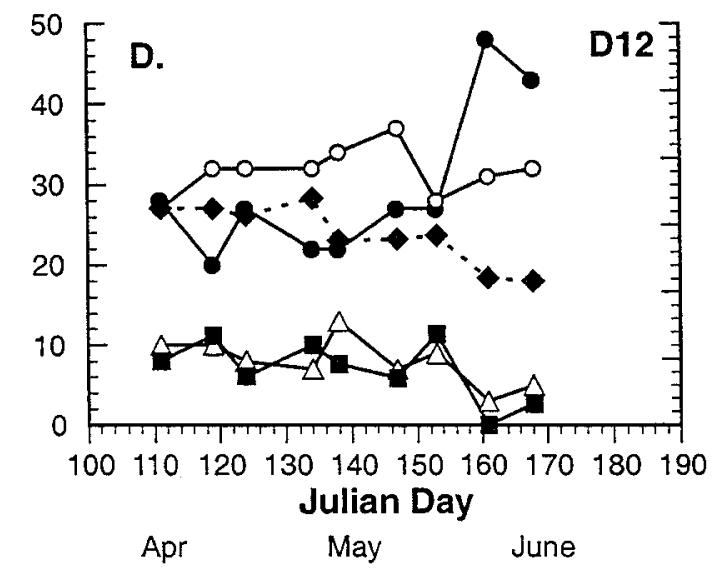


FIGURE 4.12. Relative proportions (mole \% total toxin) of different STX derivatives at three shore stations, throughout the field season. (A) Lumbo's Hole, (B) Hen's Cove, (C) Cundy's Harbor. 

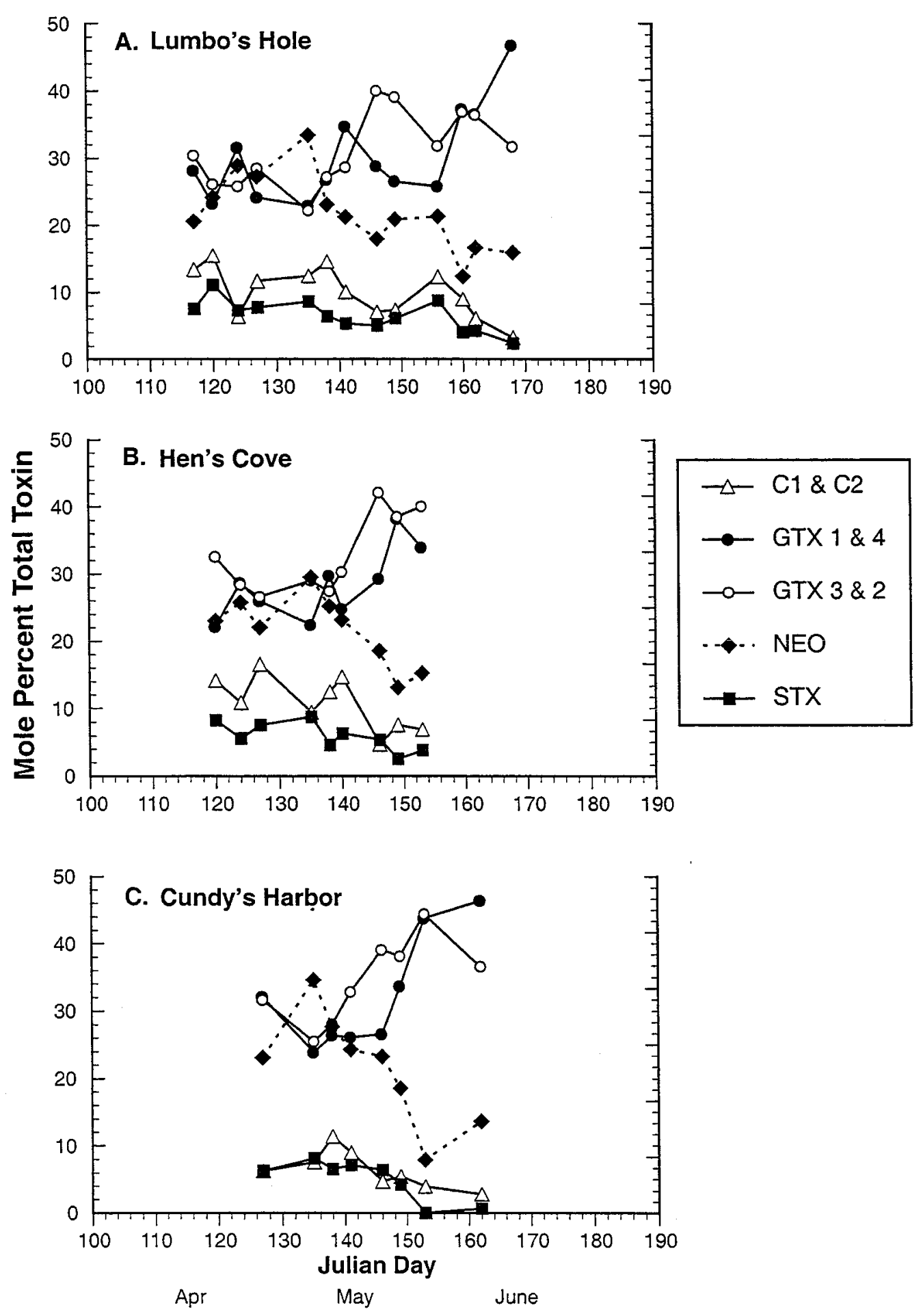
FIGURE 4.13. Toxin ratios (mol:mol) of different STX derivatives at different shipboard stations along the Transect B during the 1998 Casco Bay field season: (A I \& II) Station B3, (B I \& II) Station B6, (C I \& II) Station B9, (D I \& II) Station B12; GTX1,4:STX $(\bullet), \operatorname{GTX} 2,3: \operatorname{STX}(0), \operatorname{NEO}: \operatorname{STX}(\bullet), \mathrm{C} 1,2: \operatorname{STX}(\Delta), \operatorname{GTX} 2,3: \operatorname{NEO}(\boldsymbol{*})$,

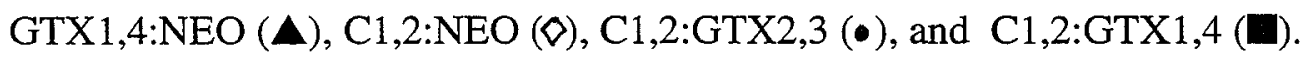



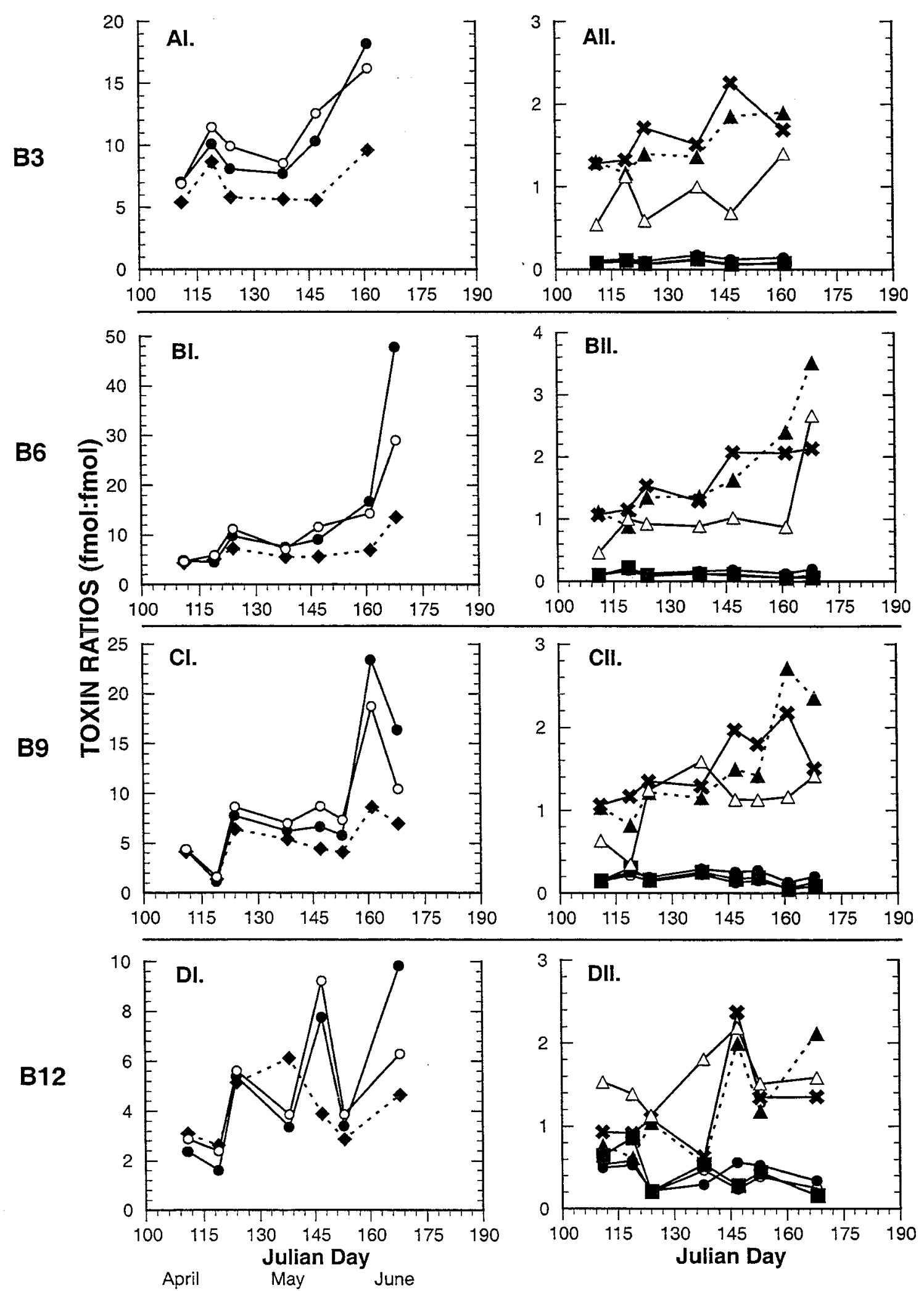
FIGURE 4.14. Toxin ratios (mol:mol) of different STX derivatives at different shipboard stations along the Transect D during the1998 Casco Bay field season. (A I \& II) Station D3, (B I \& II) Station D6, (C I \& II) Station D9, (D I \& II) Station D12; GTX1,4:STX $(\bullet)$, GTX2,3:STX (O), NEO:STX ( $)$ ), C1,2:STX ( $\Delta)$, GTX2,3:NEO (*), GTX1,4:NEO $(\boldsymbol{\Delta}), \mathrm{C} 1,2: \mathrm{NEO}(\diamond), \mathrm{C} 1,2: \mathrm{GTX} 2,3(\bullet)$, and C1,2:GTX1,4 (口). 

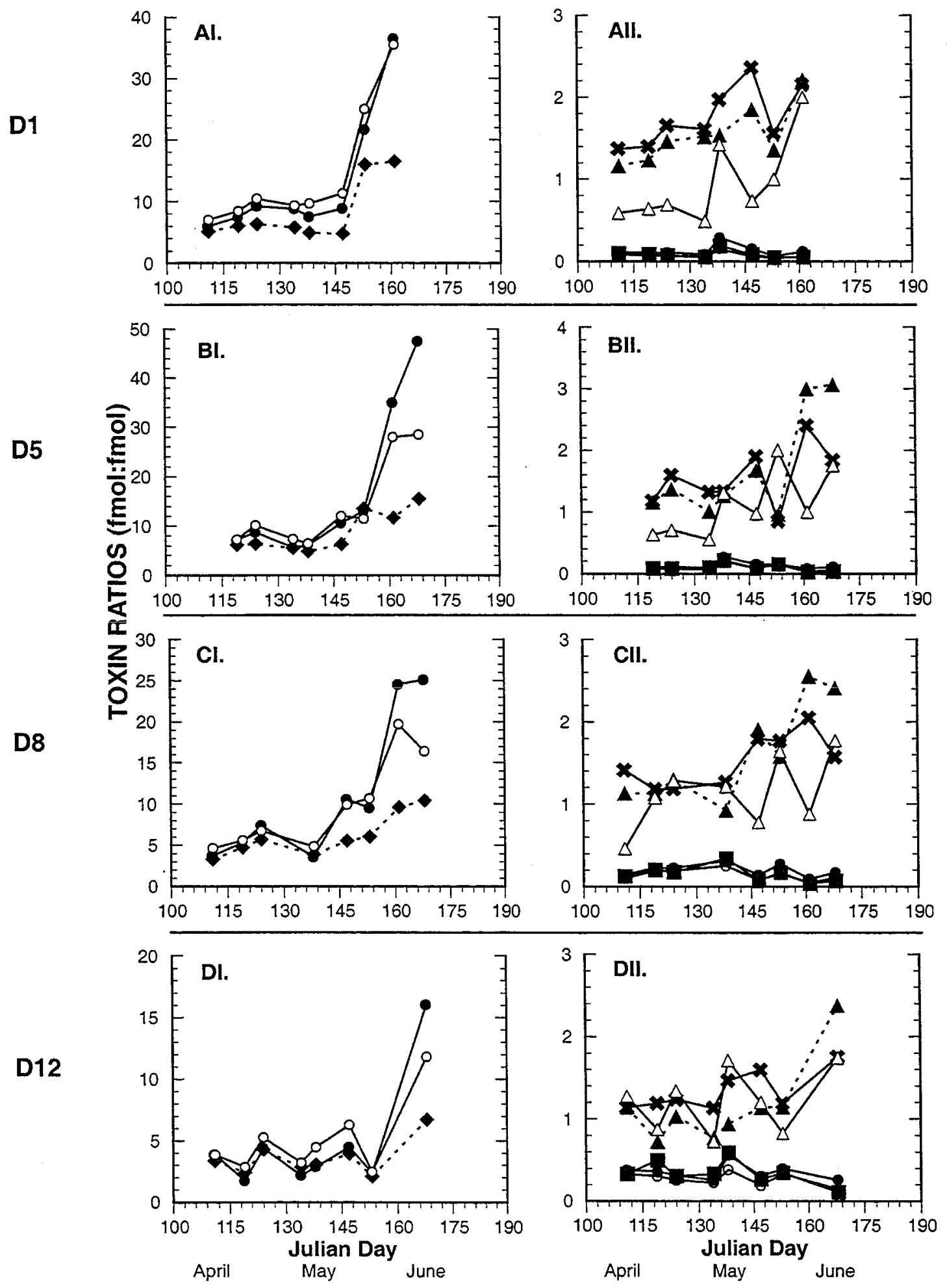
FIGURE 4.15. Toxin ratios (mol:mol) of different STX derivatives at three shore stations, Lumbo's Hole (A I \& II), Hen's Cove (B I \& II) and Cundy's Harbor (C I \& II), during the 1998 Casco Bay field season; GTX1,4:STX (-), GTX2,3:STX (O), NEO:STX $(\diamond), \operatorname{C1}, 2: \operatorname{STX}(\Delta), \operatorname{GTX} 2,3: \operatorname{NEO}(*), \operatorname{GTX} 1,4: \operatorname{NEO}(\boldsymbol{\bullet}), \mathrm{C} 1,2: \mathrm{NEO}(\diamond), \mathrm{C} 1,2: \mathrm{GTX} 2,3$ $(\bullet)$, and $\mathrm{C} 1,2: \mathrm{GTX} 1,4(\mathbf{\square})$. 

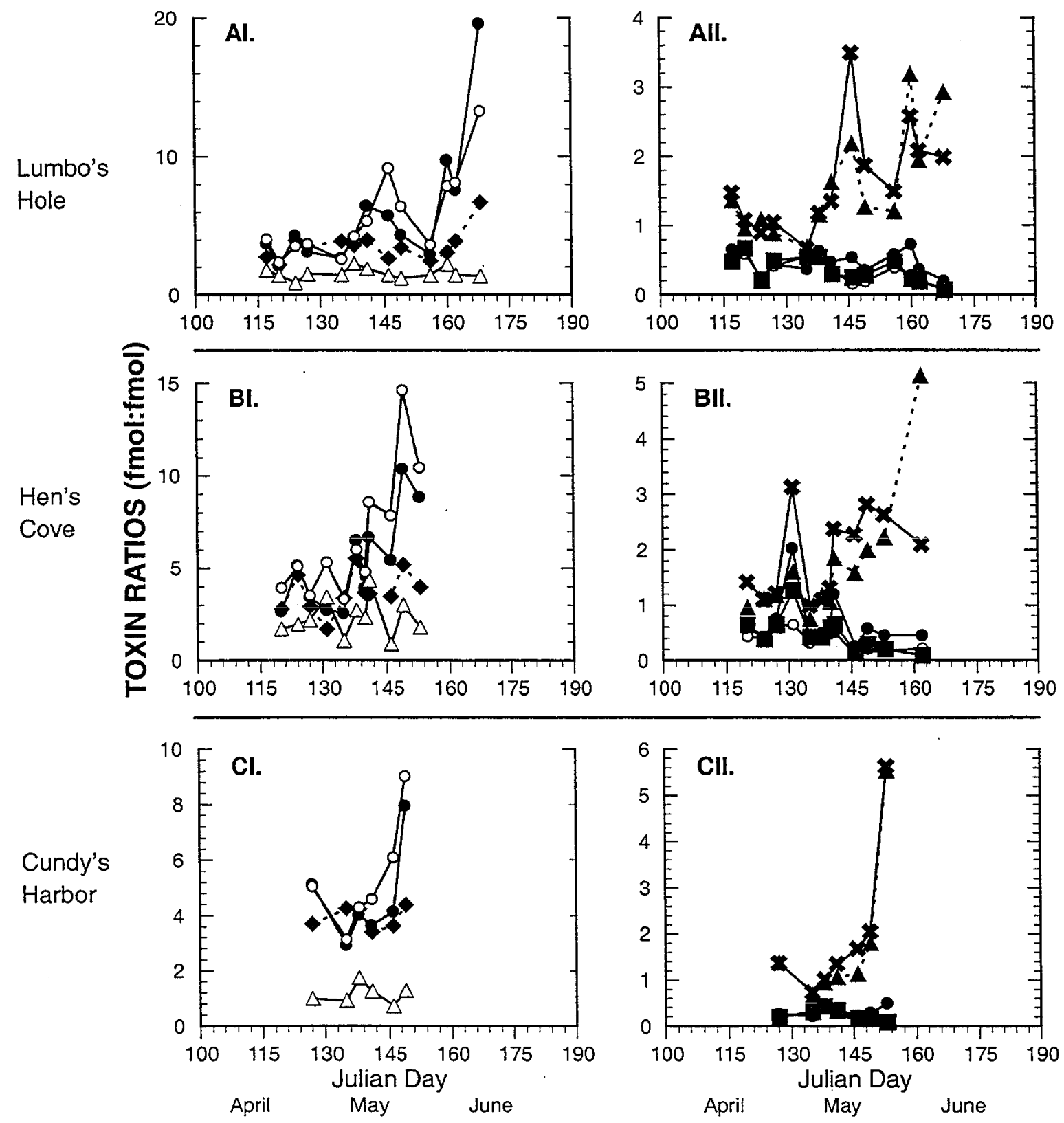


\section{DISCUSSION}

It has been previously demonstrated that the toxin content and composition of Alexandrium species vary in a systematic manner as a result of $\mathrm{N}$ - and $\mathrm{P}$ - limitation in semicontinuous culture (Anderson et al. 1990b), but these patterns have not been examined in detail during Alexandrium blooms in the natural environment. This study demonstrates that changes in toxin composition did occur over the course of a spring bloom in the Casco Bay region of the Gulf of Maine, and that these changes are generally consistent with increasing levels of $\mathrm{N}$-stress as the bloom season progressed. There is also a suggestion that the level of $\mathrm{N}$ limitation was more severe offshore compared to near shore waters, again evidenced by toxin composition patterns and the relative amounts of the different STX derivatives. These results demonstrate the great potential of field toxin measurements, and in particular, toxin composition variability and specific toxin ratios as indicators of N-limitation in natural Alexandrium populations.

Nutrient Availability. During the 1998 field season, a rapid reduction of available nutrients (specifically $\mathrm{N}$ ) accompanied relatively large increases in $A$. fundyense concentrations in the water column (Figure 4.7). During this period of bloom development (April 29-May 14), surface waters were essentially depleted of DIN (Figures 4.5 and 4.6). Past studies in the region reported that $A$. fundyense cells were typically found in $\mathrm{N}$-limited surface waters during 1993 and 1994 (Martorano 1997). Surface waters of the southwestern Gulf of Maine are predominately N-limited during the spring season, as demon- 
strated by Martorano (1997) and by the low atomic N:P ratios observed in this study (Figure $4.7 \mathrm{C}) . \mathrm{N}: \mathrm{P}$ ratios at the beginning of the field season were relatively high ( 810) but decreased to much lower values (0-5) during the latter part of the field season when $A$. fundyense abundance peaked. All of the N:P values were below the optimal Redfield ratio of 16 (Redfield 1958), that indicates potentially N-limited conditions. In addition, even though surface waters had very low DIN concentrations periodically throughout the field season, many transect stations had 3-6 $\mu \mathrm{M}$ nitrate at or below $10 \mathrm{~m}$ during stratified conditions (Figures 4.5 and 4.6). These deep pools of DIN were within reach of diel vertical migration (DVM), however, vertical migration has not been observed in Casco Bay A. fundyense (see Chapter 3).

Nutrient values at inshore stations were generally higher than those at offshore stations. This reflects freshwater inputs from the Kennebec and New Meadows Rivers, which are known to contribute significantly to surface nutrient pool in the southwestern Gulf of Maine (Martorano 1997).

The peak of the A. fundyense bloom was short in duration- approximately 2-3 weeks. The rapid decline in cell abundance that was observed at many stations could be due to decreased nutrient availability (specifically $\mathrm{N}$ ) or another environmental factor such as wind forcing or upwelling that would physically move the bloom away from the study area (Franks et al. 1992). In the former case, the decrease in $\mathrm{N}$ availability should result in the loss of cells due to cyst formation (Anderson 1998). Once cell densities during bloom conditions increase $A$. fundyense cells are able to interact with each other, where it is hypothesized that the formation of planozygotes and cysts can occur rapidly, 
decreasing the population of cells at the surface as cysts settle to bottom sediments. Sexual induction is typically induced in laboratory cultures of Alexandrium by N- or P- limitation (Anderson et al. 1984; Anderson and Lindquist 1985).

The decline in $A$. fundyense cell numbers was observed at all stations through time, and the changes in toxin composition described below both suggest that the Alexandrium population in the Casco Bay region was $\mathrm{N}$ limited even though there was significant $\mathrm{N}$ available below the pycnocline (Figures $4.5,4.6$, and 4.7). This is consistent with mesocosm observations of a Casco Bay isolate of A. fundyense (Poulton, in prep. - see Chapter 3) which did not exhibit diel vertical migration behavior (DVM) when $\mathrm{N}$-limited. In contrast to an A. tamarense isolate from the Gulf of St. Lawrence, which did migrate and acquire deep nutrients under the same conditions (MacIntyre et al. 1997), the Casco Bay strain showed clear signs of progressive N-limitation through time, even though abundant $\mathrm{N}$ was available in the deeper portion of a stratified mesocosm. I hypothesize that field populations of $A$. fundyense became progressively more N-limited over the course of the 1998 field season in the Casco Bay region, due to their inability to access deep nutrients. The combination of changes in internal physiology leading to lower growth rate and sexual induction leading to cyst formation caused cell abundance to decline rapidly by mid-June.

Toxin Concentrations and Content. Based on previous laboratory studies of Alexandrium isolates, two of the many internal biochemical changes that occur during $\mathrm{N}$ limitation are a reduction in toxin content and changes in toxin composition (Anderson et 
al. 1990b; MacIntyre et al. 1997). Here we describe changes in toxin content and composition in field samples throughout an A. fundyense bloom. Since these parameters can be measured with no interference from co-occurring organisms, they have the potential to serve as biomarkers of N-limitation for this toxigenic species. During the 1998 field season, changes in ambient toxin concentration in the smallest size class $(64-20 \mu \mathrm{m}) \mathrm{mim}-$ icked the increases and decreases in A. fundyense cell abundance (Figures $4.2 \& 4.3$ ). This close association supports the claim that STX is a unique biochemical marker for $A$. fundyense in this region. This marker was examined in two ways- by observing changes in toxin content and in toxin composition.

Toxin content represents an equilibrium between the rate of anabolism and catabolism, cell growth and division (Anderson et al. 1990a; Cembella 1998). Thus, changes in environmental factors, such as irradiance (Ogata et al. 1987; Parkhill and Cembella 1999), temperature (Hall 1982; Anderson et al. 1990a), salinity (White 1978; Parkhill and Cembella 1999), macronutrients (N \& P) (Hall 1982; Boyer et al. 1987; Anderson et al. 1990a; Anderson et al. 1990b; Flynn et al. 1996) and turbulence (Estrada and Berdalet 1998) can all affect toxin content. Figure 4.8 shows the calculated toxin content of the A. fundyense cells collected during this study. The data are highly variable, and incomplete, the latter because it was not possible to calculate reliable toxin contents when cell concentrations and toxin concentrations were both very low, as occurred at the beginning and end of the bloom interval. Dividing one highly uncertain number by another compounds the error. We conclude that toxin content is not a useful indicator of nutritional status in these field samples. 
A related parameter, the ambient toxin concentration ( $\mathrm{pmol}$ toxin $\mathrm{l}^{-1}$ ), is more accurate since the measured toxicity is expressed as a function of the volume of water pumped, which is known with accuracy. However, once again, very low toxin concentrations measured at the beginning and end of the bloom make it difficult to draw conclusions about changes in toxin content that might have occurred as the bloom declined. There is thus too much uncertainty in the toxin content field data to permit conclusions to be drawn about stresses such as nutrient limitation.

It is important to note that when sufficient cells were present for accurate counting and toxicity analysis, the averages of the toxin contents determined along Transects B and D were similar to the those obtained from N-replete Casco Bay cultures isolates (Figure 4.9). This suggests that the current method for measuring cellular toxicity in the field does yield data within the correct range of values for isolates from the region. Hopefully, with further method development and careful sample processing, toxin content will be more accurately resolved during future field studies.

Toxin Composition and Ratios. Toxin content varies with a broad range of physicochemical conditions, but the toxin composition (profile) has been considered a stable chemo-taxonomic character of different Alexandrium isolates (Cembella et al. 1987). Only in the last decade have laboratory studies shown that variations in toxin composition can occur during nutrient limited growth, if the cells are given time to adapt to their nutritional environment, as in very old batch cultures (Boczar et al. 1988) or in semicontinuous cultures (Anderson et al. 1990b; MacIntyre et al. 1997). During this Casco 
Bay study, significant changes were observed in the toxin composition of A. fundyense cells throughout the bloom. Since toxin composition is a measure of the relative abundance of different STX derivatives, it is less susceptible to errors due to low cell or toxin concentrations, as was observed for toxin content. Trends in the toxin profiles were examined through time and between stations (inshore vs. offshore) using two methods: first as changes in the relative proportions of each toxin derivative (mole \% total toxin), and then as changes in toxin ratios using the molar toxin content of each derivative. With this combined approach, trends were identified that are consistent with those from $\mathrm{N}$-limited laboratory cultures (see Chapter 3 and Table 4.3).

Table 4.3 summarizes toxicity variation results obtained for different strains of Alexandrium fundyenseltamarense using either $\mathrm{N}$ - or P-deficient batch or semicontinuous cultures. As observed throughout all the N-stressed laboratory studies, the total toxin content ( $\mathrm{fmol} \mathrm{cell}{ }^{-1}$ ) decreases significantly, as did the absolute concentration of each STX derivative (Boczar et al. 1988; Anderson et al. 1990b; MacIntyre et al. 1997; Poulton in prep; Dyhrman unpubl.). In contrast, during P-limited semi-continuous studies, the total toxin content and concentration of each STX derivative increases with GTX 2,3 exhibiting the largest increase (between 50-700 fmol cell-1) (Anderson et al. 1990b; Taroncher-Oldenburg 1998). When examining the differences in toxin composition during the $\mathrm{N}$-limited laboratory studies, trends in the relative abundances (mole $\%$ total toxin) of the different STX derivatives were less apparent than when compared to the field data. The mole \% STX decreased whereas the GTX1,4 increased for all N-limited experiments. During the two P-limited studies the trends in mole \% total toxin were 


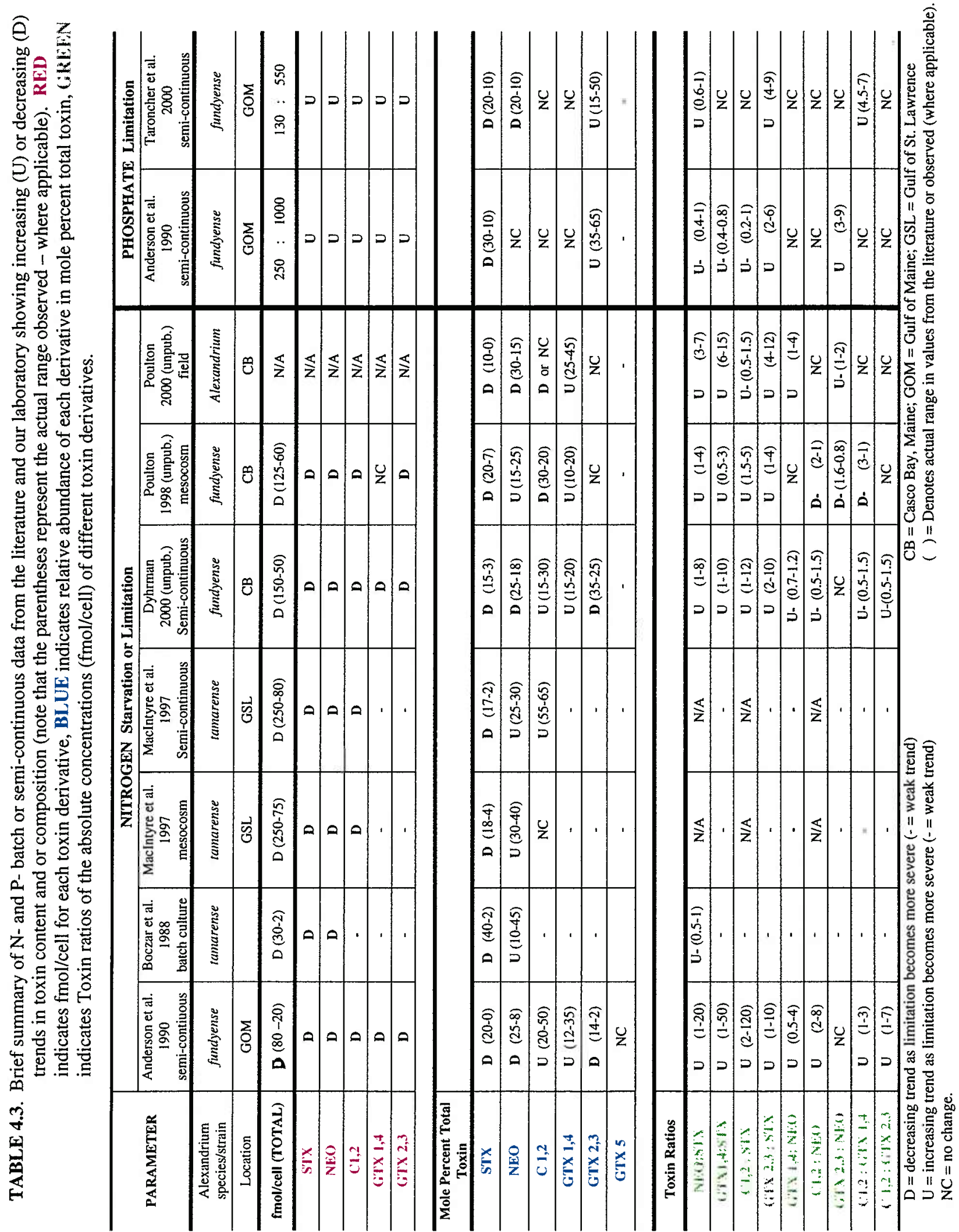


nearly identical, the strongest indicator being the large increase in mole \% GTX 2,3. As for potential indicators of $\mathrm{N}$-limitation, only the increasing trend in the relative abundance of GTX1,4 with nutrient limitation can be identified, since a decreasing trend in mole \% STX occurs during both N- and P-limitation.

The other method of examining changes in toxin composition uses ratios of the molar toxin content of different STX derivatives. In the laboratory studies in Table $4.3 \mathrm{a}$ few distinctive trends were identified using toxin ratios during both $\mathrm{N}$ - and $\mathrm{P}$-limitation. Dramatic increases in NEO:STX, GTX1,4:STX, C1,2:STX and GTX2,3:STX were observed in all N-limited laboratory studies. A much smaller increase was observed in GTX1,4:NEO in most N-limited studies. During P-limitation, GTX2,3:STX and GTX2,3:NEO increased the most, with only minor increases in NEO:STX, GTX1,4:STX, C1,2:STX. Since large increases in GTX2,3:STX occurred during both N- and P- limitation this ratio is inconclusive as a potential indicator. However, increases in NEO:STX, GTX1,4:STX, C1,2:STX and potentially GTX1,4:NEO all appear to be indicators of Nlimitation of $A$. fundyense strains from the Gulf of Maine and Casco Bay.

During the 1998 Casco Bay field season, large changes in relative proportions (mole \% total toxin) and toxin ratios were observed. Throughout most of the transects and shore stations the increasing mole \% of GTX 1,4 and decreasing mole \% of STX were consistent with previous studies using $\mathrm{N}$-limited culture (Table 4.3). The other relative toxin abundances, such as C1,2 and GTX2,3 did not vary significantly. Overall the relative proportion of different STX derivatives to the total toxin alone did not provide enough information or criteria to determine the nutrient status in the field. Since infor- 
mation is lost when mole \% proportions are calculated, such as when toxin content changes at the same time that toxin composition changes, a more logical measure of toxin composition uses only the absolute concentrations ( fmol cell ${ }^{-1}$ ) of the different STX derivatives (Taroncher-Oldenburg et al. 1999). As discussed in Chapter 3, this does not invalidate the use of mole \% data, especially as a means of comparing species either qualitatively or quantitatively under N-replete conditions. However, one should be cautious when examining changes in physiology or attempting to identify physiological indicators of nutrient stress using derivative mole $\%$ of total toxin, but instead rely on the more robust values of toxin composition such as the absolute concentration (fmol cell ${ }^{-1}$ ).of each derivative (toxin derivative cell quota).

Consistent with the $\mathrm{N}$-limited culture experiments in Table 4.3 large increases in the molar toxin ratios, NEO:STX, GTX1,4:STX, GTX2,3:STX and GTX1,4:NEO (Figures $4.12,4.13 \& 4.14$ ) were observed during the latter portion of the Casco Bay field season. This coincided with a period of very low N:P ratios (0-4) and low or undetectable DIN surface concentrations that indicate potentially $\mathrm{N}$-limiting conditions. Overall, the field toxin composition data are generally consistent with $\mathrm{N}$-limited populations of $A$. fundyense. Trends in three of the four ratios that are indicative of $\mathrm{N}$-limiting conditions in laboratory cultures were also observed in the field populations. In particular, GTX 1,4:STX increased dramatically, and this has only been observed with $\mathrm{N}$ limitation.

One inconsistency between the laboratory culture results and the Casco Bay field data relates to the low abundance of $\mathrm{C} 1,2$ toxins in the field samples. $\mathrm{C}$ toxins were very low throughout the field season, ranging from 2 to $15 \%$ of the total STX derivatives. 
During N-replete conditions, isolates from Casco Bay or the Gulf of Maine typically contain 20-30\% C-toxins or between 30-40 $\mathrm{fmol} \mathrm{cell}^{-1}$ (Figure 4.9). Furthermore, mole \% C 1,2 typically increases during semi-continuous N-limitation (Anderson et al. 1990b, MacIntyre et al. 1997; Dyhrman unpubl.), yet low concentrations were continually observed in the field samples, with no increases through time. At present we can offer no explanation as to why the C-toxin abundance was low and remained low in field populations while all other indications (nutrient concentrations, toxin ratios) were consistent with N-limitation. Although interconversions via hydrolysis do occur, this appears unlikely since the hydrolyzed products of $\mathrm{C} 1$ and C2 are GTX 2 and GTX3, and the abundance of GTX 2,3 was not significantly elevated compared to N-replete conditions. There is a clear need for further investigation on how Casco Bay isolates vary their toxicity (and particularly the $\mathrm{C}$ toxins) in response to $\mathrm{N}$ limitation, and how genetically similar isolates from Casco Bay are to natural populations through time in the field.

Several toxins appear to be more abundant inshore (in both transect and shore stations) compared to offshore stations. This inshore/offshore trend was observed in the mole \% STX distribution, as well as in C1,2. Using a Tukey's multiple comparison test, the offshore station, D1 was significantly different $(\mathrm{p}<0.05)$ from the inshore station, D12, where the mole \% STX was approximately $10 \%$ inshore and 5\% offshore. Since inshore stations are exposed to greater quantities of nutrients due to riverine inputs, and STX is known to increase as nutrient availability increases (Table 4.3), the observed differences between inshore and offshore toxicity may be nutrient-driven, but at this time and without further evidence, our conclusions are speculative. 
Toxin Composition as a Nutrient Indicator. Some of the stations (e.g., Cundy's Harbor, Lumbo's Hole) were in sheltered areas with limited tidal flushing, and thus it is reasonable to expect that the repeated sampling followed the same population through time. Trends in toxin composition observed at those sites (Figures 4.12 and 4.15) were similar. to those observed for the more exposed, offshore transect stations (Figures $4.10 \mathrm{~A}, 4.11$ A, 4.13 A and 4.14 A). This is consistent with the similarities in toxin composition observed for six different Casco Bay isolates of A. fundyense that we analyzed (Figure 4.9), and with toxicity patterns observed in a larger study of Alexandrium isolates in the Gulf of Maine (Anderson et al. 1994).

Another concern is that the weekly cruises would sample cells from different water masses one week to the next, given the along-shore movement of the coastal water offshore of Casco Bay (Anderson 1997). If those populations had different nutritional histories, it would not be possible to discern or explain trends in toxin composition through time. Here again, the close similarities between the toxin composition trends observed at the shore stations and those at the transect stations argues that the regional population experienced relatively similar nutritional and environmental conditions.

Taken together, the weight of the evidence is that $A$. fundyense cells became progressively $\mathrm{N}$ limited during the bloom season. The rapid decline in DIN in surface waters and the changes in the toxin composition profile and cell abundance all are consistent with this scenario, with one exception - namely the relatively low abundance of the $\mathrm{C}$ toxins, which typically increase with N-limitation. Since most of the trends observed were similar for both the on and offshore cell populations, this suggests that populations 
throughout the region may have had similar histories. Overall, the trends observed are quite remarkable, since they require great nutritional uniformity between the near shore and offshore populations.

Summary. The observed trends in the toxin ratios for $A$. fundyense were generally indicative of $\mathrm{N}$-limitation as bloom termination occurred at the end of the field season. It should be noted that these changes in toxicity patterns are dependent on the initial toxin profile of the strain from the region of interest, and these toxins vary to different degrees with a given stress. For example, in the $A$. fundyense isolates from the Casco Bay region there are 5 dominant toxins $(>15-20 \%)$ whereas, a Gulf of St. Lawerence $A$. tamarense isolate has only 3 major toxins, so, its changes in toxin composition will most likely differ in magnitude. Therefore, prior to using these indicators in the field for a particular region, it is necessary to characterize the response of regional isolates to a suite of nutritional stresses.

This initial examination of toxicity in $A$. fundyense field populations has raised many questions regarding physiological responses to environmental stress. Additional field and laboratory studies are needed to verify the results presented here, which are compelling, but not conclusive. One key issue that needs more focus in future field studies is the ability to accurately determine toxin content when cells and toxicity are both low in concentration. Further method development and careful sample processing are required in order to obtain accurate cell counts and toxin measurements. 
In conclusion, this study examined for the first time changes in toxin content and composition throughout an $A$. fundyense bloom. Many environmental factors, such as temperature, stratification, and nutrient concentration changed dramatically during the bloom season, yet it was still possible to discern patterns in toxin composition that were generally consistent with progressive $\mathrm{N}$-limitation. That this was possible in a dynamic coastal environment is truly remarkable, and thus should be repeated, both in the Casco Bay region and elsewhere. Further efforts are clearly needed to prove the validity of what appears to be a robust indicator of $\mathrm{N}$-limitation for toxic Alexandrium species in natural waters. 


\section{ACKNOWLEGDEMENTS}

We would like to thank the shipboard and technical assistance of Kristin Gribble, Sonya Dyhrman, Jim Churchill, Jeff Turner, Dave Lawrence, Dave Kulis, Ted Loder, Robert Brudrow, Becky Claus, Mario Sengco and the crew of the RV Gulf Challenger from the University of New Hampshire, Durham NH. This research was supported by the U.S. ECOHAB-GOM (Ecology and Oceanography of Harmful Algal Blooms-Gulf of Maine) Program National Science Foundation Grant OCE - 9808173 and the EPA Star Graduate Fellowship (\# U-915038-01-0). Contribution \#\#\# from the Woods Hole Oceanographic Institution, and Contribution \# from the U.S. ECOHAB Program, sponsored by NOAA, NSF, EPA, NASA, and ONR. 


\section{REFERENCES}

Adachi, M., Y. Sako, Y. Ishida, D. M. Anderson and B. Reguera (1993). "Crossreactivity of five monoclonal antibodies to various isolates of Alexandrium as determined by an indirect immunofluorescence method." Nippon Suisan Gakkaishi 59(10): 1807.

Anderson, D. M. (1990). Toxin variability in Alexandrium species. In: E. Graneli, B. Sundström, L. Edler and D. M. Anderson (eds.) Toxic Marine Phytoplankton. pp. 4151. Elsevier.

Anderson, D. M. (1998). Physiology and bloom dynamics of toxic Alexandrium species; with emphasis on life cycle transitions. In: D. M. Anderson, A. D. Cembella and G. M. Hallegraeff (eds.) Physiological Ecology of Harmful Algal Blooms, SpringerVerlag. G. 41: 29-48.

Anderson, D. M., D. M. Kulis and B. J. Binder (1984). "Sexuality and cyst formation in

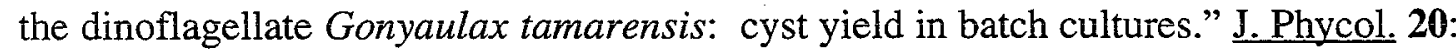
418-425.

Anderson, D. M., D. M. Kulis, G. J. Doucette, J. C. Gallagher and E. Balech (1994). "Biogeography of toxic dinoflagellates in the genus Alexandrium from the northeastern United States and Canada." Mar. Biol. 120: 467-478.

Anderson, D. M., D. M. Kulis and B. A. Keafer (1999). "Detection of the toxic dinoflagellate Alexandrium fundyense (Dinophyceae) with oligonucleotide and antidbody probes: variability in labeling intensity with physiological condition." J. Phycol. 35: $870-883$.

Anderson, D. M., D. M. Kulis, J. J. Sullivan and S. Hall (1990). "Toxin composition variations in one isolate of the dinoflagellate Alexandrium fundyense." Toxicon 28(8): 885-893.

Anderson, D. M., D. M. Kulis, J. J. Sullivan, S. Hall and C. Lee (1990). "Dynamics and physiology of saxitoxin production by the dinoflagellates Alexandrium spp." Mar. Biol. 104: $511-524$. 
Anderson, D. M. and N. L. Lindquist (1985). "Time-course measurements of phosphorus depletion and cyst formation in the dinoflagellate Gonyaulax tamarensis." J. Exp. Mar. Biol. Ecol. 86: 1-13.

Boczar, B. A., M. K. Beitler, J. Liston, J. J. Sullivan and R. A. Cattolico (1988). "Paralytic shellfish toxins in Protogonyaulax tamarensis and Protogonyaulax catenella in axenic culture." Plant Physiol. 88: 1285-1290.

Boyer, G. L., J. J. Sullivan, R. J. Andersen, P. J. Harrison and F. J. R. Taylor (1987). "Effects of nutrient limitation on toxin production and composition in the marine dinoflagellate Protogonyaulax tamarensis." Mar. Biol. 96: 123-128.

Cembella, A. D. (1998). Ecophysiology and metabolism of paralytic shellfish toxins in marine microalgae. In: . D. M. Anderson, A. D. Cembella and G. M. Hallegraeff (eds.) Physiological Ecology of Harmful Algal Blooms. Springer-Verlag. G 41: 381403.

Cembella, A. D., J. J. Sullivan, G. L. Boyer, F. J. R. Taylor and R. J. Andersen (1987). "Variation in paralytic shellfish toxin composition within the Protogonyaulax tamarensis/catenella species complex: red tide dinoflagellates." Biochem. System. Ecol. 15: 171-186.

Estrada, M. and E. Berdalet (1998). Effects of turbulence on phytoplankton. In: D. M. Anderson, A. D. Cembella and G. M. Hallegraeff (eds.) Physiological Ecology of Harmful Algal Blooms. Springer-Verlag. Vol. G 41.

Flynn, K., J. M. Franco, P. Fernandez, B. Reguera, M. Zapata, G. J. Wood and K. J. Flynn (1994). "Changes in toxin content, biomass and pigments of the dinoflagellate Alexandrium minutum during nitrogen refeeding and growth into nitrogen or phosphorous stress." Mar. Ecol. Prog. Ser. 111: 99-109.

Flynn, K., K. J. Jones and K. J. Flynn (1996). "Comparisons among species of Alexandrium (Dinophyceae) grown in nitrogen- or phosphorous-limiting batch culture." Mar. Biol. 126: 9-18. 
Guillard, R. R. L. (1975). Culture of phytoplankton for feeding marine invertebrates. In: W. L. Smith and M. H. Chanley (eds.) Culture of marine invertebrate animals. pp. 2960. Plenum Publishing Corp.

Hall, S. (1982). PhD Toxins and toxicity of Protogonyaulax from the Northeast Pacific. University of Alaska, Fairbanks, p.196.

Hallegraeff, G. M. (1993). "A review of harmful algal blooms and their apparent global increase." Phycologia 32: 79-99.

Lachat, I. (1993). Silicate in brackish or seawater. QuikChem Method 31-114-27-1-B, Lachat Instruments, 6645 West Mill Road, Milwaukee, WI 53218.

Lachat, I. (1994a). Ammonia in brackish or seawater. QuikChem Method 31-107-06-1-A, Lachat Instruments, 6645 West Mill Road, Milwaukee WI 53218.

Lachat, I. (1994b). Nitrate in brackish or seawater. QuikChem Method 31-107-04-1-A, Lachat Instruments, 6645 West Mill Road, Milwaukee, WI 53218.

Lachat, I. (1994c). Phosphate in brackish or seawater. QuikChem Method 31-115-01-3A, Lachat Instruments, 6645 West Mill Road, Milwaukee, WI 53218.

MacIntyre, J. G., J. J. Cullen and A. D. Cembella (1997). "Vertical migration, nutrition and toxicity in the dinoflagellate Alexandrium tamarense." Mar. Ecol. Prog. Ser. 148: 201-216.

Martorano, C. D. (1997). MSc. Nutrient dynamics during blooms of Alexandrium spp. in the southwestern Gulf of Maine, University of New Hampshire, Durham, NH, p.132.

Matsuda, A., T. Nishijima and K. Fukai (1996). Effects of nitrogen deficiency on the PSP production by Alexandrium catenella under axenic cultures. In: T. Yasumoto, Y. Oshima and Y. Fukuyo (eds.) Harmful and Toxic Algal Blooms. pp. 305-308. UNESCO.

Ogata, T., T. Ishimaru and M. Kodama (1987). "Effect of water temperature and light intensity on growth rate and toxicity change in Protogonyaulax tamarensis." Mar. Biol. 95: 217-220. 
Oshima, Y. (1995). Post-column derivatization HPLC methods for paralytic shellfish poisons. In: . G. M. Hallegraeff, D. M. Anderson and A. D. Cembella (eds.) Manual on harmful marine microalgae. IOC manuals and guides. UNESCO. No. 33: 81-94.

Oshima, Y., S. I. Blackburn and G. M. Hallegraeff (1993). "Comparative study on paralytic shellfish toxin profiles of the dinoflagellate Gymnodinium catenatum from three. different countries." Mar. Biol. 116: 471-476.

Oshima, Y. S., K. Sugino and T. Yasumoto (1989). Latest advances in HPLC analysis of paralytic shellfish toxins. Mycotoxins and phycotoxins: Proc. 7th IUPAC Symposium.

Parkhill, J. P. and A. D. Cembella (1999). "Effects of salinity, light and inorganic nitrogen on growth and toxigenicity of the marine dinoflagellate Alexandrium tamarense from northeastern Canada." J. Plankton Res. 21: 939-955.

Redfield, A. C. (1958). "The biological control of chemical factors in the environment." Am. Sci. 46: 205-221.

Rhee, G. Y. (1978). "Effects of N:P atomic ratios and nitrate limitation on algal growth, cell composition, and nitrate uptake." Limnol. Oceanogr. 23: 10-25.

Sako, Y., M. Adachi and Y. Ishida (1993). Preparation and Characterization of Monoclonal Antibodies to Alexandrium Species. In: T. J. Smayda and Y. Shimizu (eds.) Toxic Phytoplankton Blooms of the Sea. pp. 87-93. Elsevier.

Sako, Y., N. Naya, T. Yoshida, C.-H. Uchida and Y. Ishida (1995). Studies on stability and heredity of PSP toxin composition in the toxic dinoflagellate Alexandrium. In: P. Lassus, G. Arzul, E. Erard, P. Gentien and C. Marcaillou (eds.) Harmful Marine Algal Blooms. pp. 345-350 Lavoisier.

Taroncher-Oldenburg, G. (1998). PhD. Cell Cycle Dynamics and Physiology of Saxitoxin Biosynthesis in Alexandrium fundyense (Dinophyceae), Massachusetts Institute of Technology, Cambridge p. 205.

Taroncher-Oldenburg, G., D. M. Kulis and D. M. Anderson (1999). "Coupling of saxitoxin biosynthesis to the $\mathrm{G} 1$ phase of the cell cycle in the dinoflagellate Alexandrium fundyense: temperature and nutrient effects." Natural Toxins 7: 207-219. 
Turner, J. T., G. J. Doucette, C. L. Powell, D. M. Kulis, B. A. Keafer and D. M. Anderson (2000). "Accumulation of red tide toxins in larger fractions of zooplankton assemblages from Massachusetts Bay, USA.” Mar. Ecol. Prog. Ser. submitted.

Utermöhl, H. (1958). "Neue Wege in der quantitativen Erfassung des Planktons (mit besonderer Berücksichtigung des Ultraplanktons." Verh. int. Ver. theor. angew. Limnol. 5: 567-596.

Valderrama, J. C. (1981). "The simultaneous analysis of total nitrogen and total phosphorous in natural waters." Mar. Chem. 10: 109-122.

White, A. W. (1978). "Salinity effects on growth and toxin content of Gonyaulax exca-

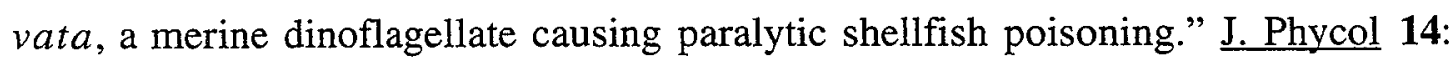
475-479. 
GENERAL CONCLUSIONS 
The work described in this thesis has provided new insights on the physiological and behavioral effects of N-limitation for Alexandrium fundyense, from Casco Bay, Maine and how one of these physiological parameters, specifically toxin composition, may be used to examine and identify changes in nitrogen availability for natural Alexandrium populations. With the use of toxin composition and other physiological indicators as identified in $\mathrm{N}$-limited laboratory cultures ( $\mathrm{N}$-starved vs. $\mathrm{N}$-acclimated) it could be possible to examine the nutritional status of Alexandrium in field populations using cell separation methods such as flow cytometry and immunomagnetic isolation. Overall, this thesis has demonstrated that it's possible to separate cells from field samples for physiological studies and that diagnostics of N-limitation can be identified.

The second chapter (first data chapter) examined two immunological approaches for identifying and separating Alexandrium fundyense from field samples and described attempts to measure physiological parameters of isolated cells. The first approach utilized flow cytometric detection in combination with a surface-specific monoclonal antibody in conjunction with a series of secondary fluorochromes to positively identify and separate Alexandrium from field samples. Although cell enumeration was unsuccessful using flow cytometry, A. fundyense cells were successfully identified and separated optimally using fluorecein isothiocyanate (FITC), a green fluorochrome as secondary antibody. In addition, flow cytometric cell sorting was identified as a possible method of isolating cells for biochemical analysis. A second approach was also examined that adapted immunomagnetic separation methods to separate $A$. fundyense from live mixed field assemblages using magnetic beads. Using an indirect method of bead attachment 
and a surface-specific monoclonal antibody, A. fundyense cells were successfully separated and examined for biochemical determinations. Overall, immunomagnetic bead separation was found to adequately separate cells and comparisons of biochemical determinations before and after bead separation showed no significant differences for most biochemical measurements (chlorophyll a, protein, $\mathrm{C}$ and $\mathrm{N}$ ). This result is significant in that these methods can be applied to natural Alexandrium populations during field studies to determine species-specific physiological estimates. The combined approach of flow cytometry and immunomagnetic bead technology in future field studies could expand our knowledge of the physiological changes that occur during natural Alexandrium blooms.

In Chapter three, I examined how different levels of nitrogen availability affect the behavior and intracellular biochemical composition of A. fundyense from Casco Bay, Maine. First, using a $2 \mathrm{~m}$ tall laboratory mesocosm I found that $A$. fundyense from the Casco Bay region lack the behavioral adaptation to vertically migrate once nitrogen is limiting in the surface layer. This result was unexpected, since a Gulf of St. Lawrence $A$. tamarense isolate has been shown to vertically migrate during low surface nitrate conditions. However, this lack of vertical migration is significant since it concludes that there can be wide variation in behavioral adaptations between different species or strains that originate from different regions. In addition to behavioral studies, biochemical responses to changes in nitrogen availability were identified for $\mathrm{N}$-starvation, $\mathrm{N}$-limitation (acclimation) and $\mathrm{N}$-replete conditions. 
Once indicators were developed for $\mathrm{N}$-stress, variability in toxin content and composition were examined in the coastal waters of Casco Bay, Maine during an A. fundyense bloom in the spring of 1998. Over the course of the field season, toxin compositional changes did occur that were generally consistent with increasing levels of $\mathrm{N}$ stress as the bloom progressed and $\mathrm{N}$ levels decreased. As observed in $\mathrm{N}$-limited culture, large increases in some toxin ratios (e.g., GTX1,4:STX and NEO:STX) were observed during the latter portion of the field season, coinciding with low N:P ratios and undetectable levels of dissolved inorganic nitrogen. Overall, the toxin compositional trends are quite remarkable and suggest that this approach may provide valuable species-specific physiological information with the need for elaborate cell separation schemes such as flow cytometry or immunomagnetic bead sorting. Further laboratory studies are needed to better characterize the toxin response of $A$. fundyense isolates to environmental stresses before this suite of toxin indicators can be considered robust.

Overall, the development of physiological indicators and methods for cell identification and separation of $A$. fundyense will allow researchers to monitor natural blooms and identify and understand how changes in the environment such as nutrients, light, temperature and salinity effect their distribution and occurrence. Since toxin production is a distinguishing characteristic of $A$. fundyense and many other harmful algal bloom species, nutrient availability has a clear and significant influence on the variability in toxin production and composition. This thesis begins to elucidate more of the biochemical and cellular mechanisms and how limiting nutrients (specifically nitrogen) alters the cellular toxicity in the laboratory and in the coastal environment. Without more informa- 
tion about nutrient physiology of these cells during changing environmental conditions it is very difficult to assess the ecological role of toxins in population and community dynamics. 


\section{Abbreviations and Acronyms}

BP

BSA

CB

chl $a$

CTD

$\mathrm{cm}$

${ }^{\circ} \mathrm{C}$

ca.

d

DCMU

DMEM

DNA

DVM

ECOHAB

ed.

eds.

et

et al.

e.g.

FCS

FITC

FLS

$\mathrm{F}_{\mathrm{v}} / \mathrm{F}_{\mathrm{m}}$

g

GLN

GLU

GOM band pass

bovine serum albumin

Casco Bay (Maine)

chlorophyll $a$

conductivity, temperature and depth

centimeter

degree Celsius

circa (around)

day

[3-(3,4-dichlorophyenyl)-1,1-dimethylurea]

Dulbecco's Modified Eagle's Medium

deoxyribonucleic acid

diel vertical migration

Ecology \& Oceanography of Harmful Algal Blooms

editor

editors

and

et alia (and others)

exempli gratia (for example)

fetal calf serum

fluorecein isothiocyanate

forward light scatter

variable fluorescence/maximal fluorescence

gram

glutamine

glutamate

Gulf of Maine 


\begin{tabular}{|c|c|}
\hline GSL & Gulf of St. Lawrence \\
\hline h & hour \\
\hline $\mathrm{HCL}$ & hydrochloric acid \\
\hline HoAc & acetic acid \\
\hline HPLC & high performance liquid chromatography \\
\hline i.e. & id est (that is) \\
\hline $\operatorname{IgG}_{1}$ & Immunoglobulin protein, subclass $\mathrm{G}_{1}$ \\
\hline in prep. & in preparation \\
\hline $\mathrm{km}$ & kilometer \\
\hline $\mathrm{L}$ & liter \\
\hline LP & long pass \\
\hline $\mathrm{m}$ & milli- $\left(10^{-3}\right)$ or meter \\
\hline $\mathrm{M}$ & molar \\
\hline MA & Massachusetts \\
\hline $\mathrm{MAb}$ & monoclonal antibody or antiserum \\
\hline ME & Maine \\
\hline $\min$ & minute \\
\hline$\mu \mathrm{m}$ & micrometer \\
\hline$\mu \mathrm{M}$ & micromolar \\
\hline$\mu \mathrm{mol}$ & micromoles \\
\hline MPC & magnetic particle concentrator \\
\hline $\mathrm{MTT}$ & Massachusetts Institute of Technology \\
\hline $\mathrm{ml}$ & milliliter \\
\hline $\mathrm{mm}$ & millimeter \\
\hline MMP & mouse myloma protein \\
\hline $\mathrm{mW}$ & milliwatt \\
\hline MW & molecular weight \\
\hline $\mathrm{N}$ & normal \\
\hline $\mathrm{n}$ & number \\
\hline
\end{tabular}


NGS

NS

NSS

$\mathrm{nm}$

PAR

ppt

PBS

PE

PVC

$\mathrm{q}$

rpm

RNA

S

sp.

spp.

SSC

$\mathrm{SaM}$

$\mathrm{SD}$

SE

$\mathrm{NaCl}$

UV

VSW

$\mathrm{v} / \mathrm{v}$ normal goat serum

Nova Scotia

normal sheep serum

nanometer

photosynthetic available radiation

parts per thousand

phosphate buffered saline

phycoerythrin

polyvinyl chloride

quanta

revolutions per minute

ribonucleic acid

second

species (singular)

species (plural)

side scatter

sheep anti-mouse

standard deviation

standard error

sodium chloride

ultraviolet

Vineyard Sound seawater

volume per volume 


\section{ACKNOWLEDGEMENTS}

I would like to thank the following people and funding agencies for their help and support:

Mum, Dad and Susan, I couldn't have done this without all of your encouragement -

I thank you!

Friends: I would especially like to thanks Brenda Jensen \& Liz Kujawinski for being there through every waking moment, and keeping me going. Adnan Mirza, my oldest and dearest friend, I thank you for the long telephone conversations and the attempts to get together over the years, hopefully we'll see more of these other.

John Waterbury and Freddy Valois - for giving me the opportunity to come to WHOI! Heather and Danny Kirk-Davidoff, Penny Chisholm - plus past and present lab members. Julian Sachs, for teaching me to sail and all the adventures on "Fearless", WHOI - 94 and other associated friends such as, Omak. Bill Shaw, Sean Callahan, Lihini, Anne Sell (and family), Yale, Andreas Teske, BLee Williams, Heather Hunt, Karin, Dag (\& Atle), Carolina Luxoro for fun on and off of Pogue Ma Thon. The Doppelkoff players: Sonya Dyhrman, Anne Sell, Marinna Martini, Barabara Neihoff, Aikiko Okusu, Sandra Werner, Mark Hill, Angela Tymrak (\& Hero). Eliza Garfield (for future adventures with CHALLENGER!), Larry Newsome, Matt Heinz,

\section{AND Michael....thanks for everything (esp. your patience!)}

Mark and Deb Albert (\& family), Ken and Vicky Page, Chris and Jackie Whelan, and many others from the Woods Hole Community that made me feel at home.

The HALIFAX CREW: J. Geoff MacIntyre, Gary Maillet, Richard Davis, Jean Paul Parkhill, Cathy Ryan, Yaohong Zhang, Yannik, and others including housemates - Anna Metaxas too!

The ANDERSON CREW: Members past and present. Including Dave Kulis, Bruce Keafer, Judy Kleindinst, Kristin Gribble, Mario Sengco, Elle Lilly, Kalle Oli, Aishao Li, Graziela Persich, Gaspar \& Ee Lin, Deana Erdner, Raffael Jovine, John Kokinos, May and Sonso!!, and many, many others....

Committee Members: John J. Cullen, Penny Chisholm, Michael Sieracki, \& Rob Olson. especially my advisor - DON ANDERSON.

Funding Sources:

The WHOI Education Office (and people: Julia, Stella, Marcy,\& John)

The National Science Foundation (NSF - OCE - 9808173)

NOAA - Sea Grant - (NA86RG0075)

Environmental Protection Agency - graduate fellowship (U-915038-01-0) 
